\title{
Lumineszcencia centrumok kialakítása és spektrális jellemzése nanogyémántban
}

\author{
Ph.D. értekezés
}

\section{Himics László}

Témavezető:

\author{
Dr. Koós Margit \\ az MTA doktora
}

MTA Wigner Fizikai Kutatóközpont

Szilárdtestfizikai és Optikai Intézet
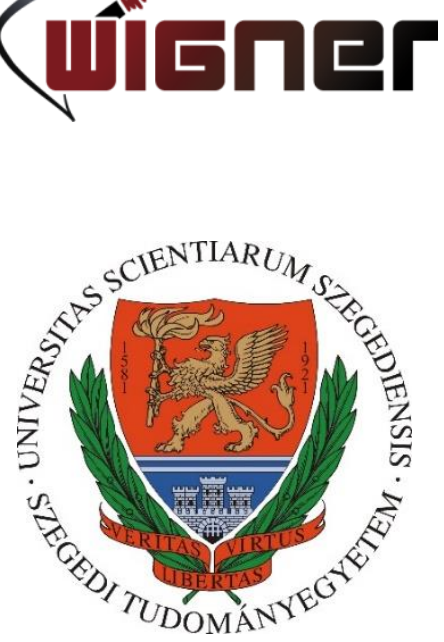

Szegedi Tudományegyetem

Természettudományi és Informatikai Kar

Fizika Doktori Iskola

Szeged, 2016 


\section{TARTALOMJEGYZÉK}

1. RÖVIDÍTÉSEK ÉS JELÖLÉSEK JEGYZÉKE 1

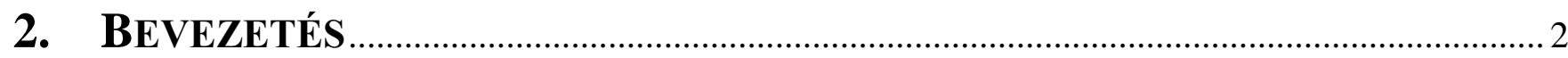

3. IRODALMI ELŐZMÉNYEK …….........................................................................

3.1. A gyémánt, mint mátrix-anyag színcentrumok kialakítására .......................................... 5

3.2. Nitrogént tartalmazó szennyezési centrumok a gyémántban ........................................ 8

3.2.1. Az $N 3$ centrum atomi szerkezete és kialakítása gyémántban .....................................

3.2.2. Az $N 3$ centrumok fotolumineszcencia tulajdonságai ................................................ 11

3.2.2.1. A fotolumineszcencia rezonáns és nem rezonáns gerjesztése........................ 12

3.2.2.2. Az N3 centrum lumineszcenciájának gerjesztési spektruma ......................... 13

3.2.2.3. Az N3 centrum lumineszcencia spektruma ............................................... 16

3.2.2.4. Az N3 centrum zérusfonon vonalának spektrális jellemzöi ........................... 17

3.2.2.5. Elektron-fonon csatolás az N3 centrumnál .............................................. 18

3.3. A szilícium-vakancia ( $\mathrm{SiV})$ optikai centrum gyémántban.............................................. 20

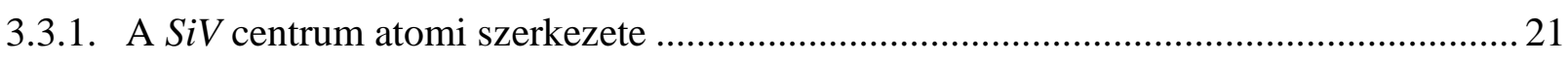

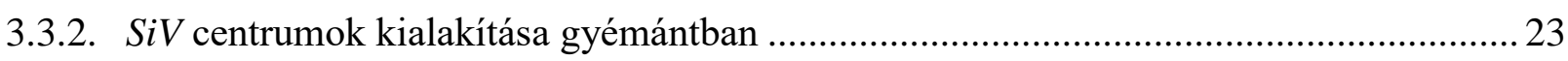

3.3.3. A SiV centrum lumineszcencia tulajdonságai ............................................................ 24

3.3.3.1. A SiV centrum emissziós spektruma ......................................................... 24

3.3.3.2. A SiV centrum emissziójának gerjesztési spektruma ..................................... 26

3.3.3.3. A SiV centrum zérusfonon vonalának spektrális jellemzöi ............................ 27

3.3.3.4. Elektron-fonon csatolás a SiV centrumnál .................................................. 28

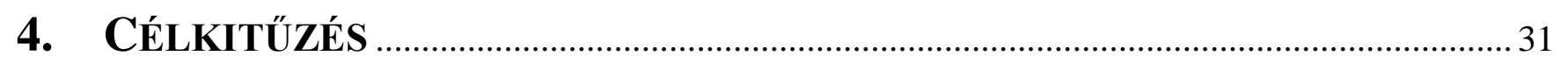

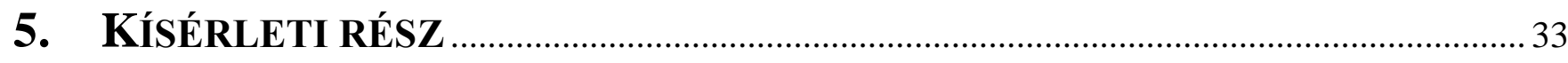

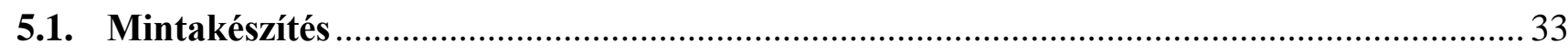

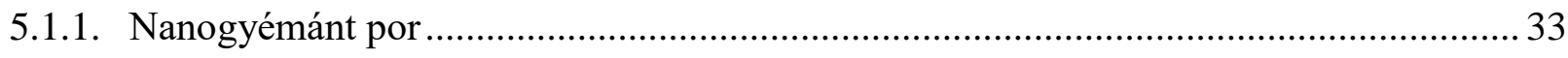

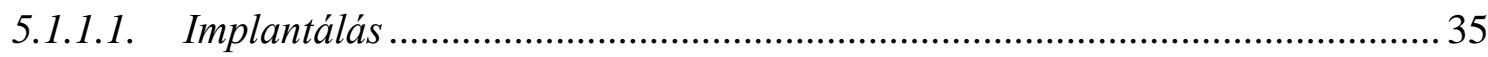

5.1.1.2. Az implantált nanogyémánt minták hökezelése .......................................... 37

5.1.1.3. A nitrogénszennyezés és a vakancia mélységeloszlása ................................. 37

5.1.2. Nanogyémánt vékonyrétegek előállítása MW CVD módszerrel ................................... 40

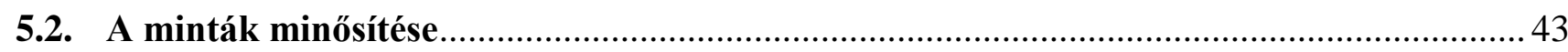


5.2.1. Raman-spektroszkópia .43

5.2.2. Pásztázó elektronmikroszkópia nanogyémánt vékonyrétegeken ..................................51

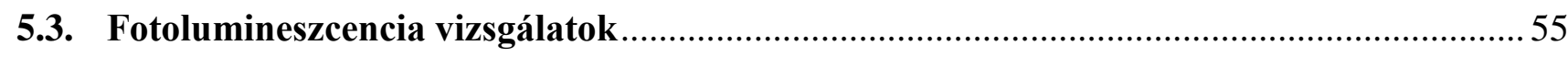

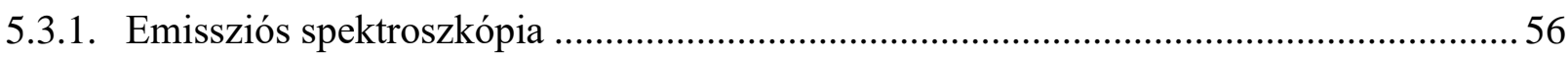

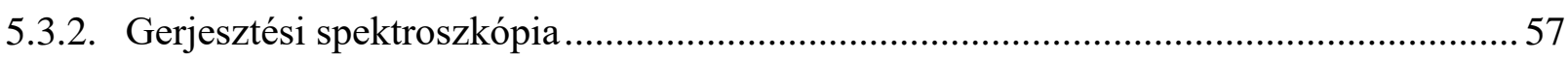

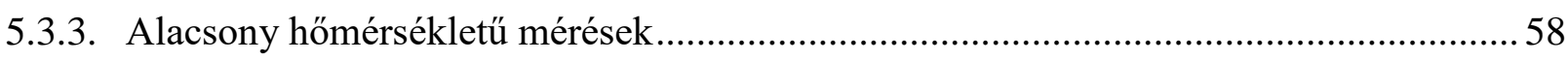

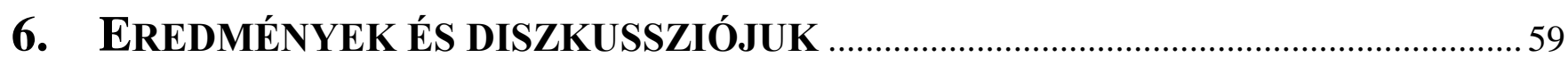

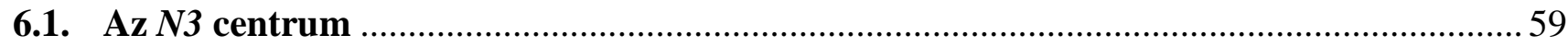

6.1.1. A kezeletlen nanogyémánt szemcsék fotolumineszcenciája ........................................59

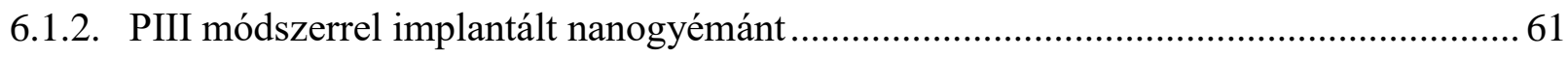

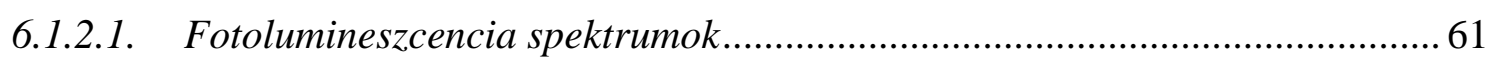

6.1.2.2. A hökezelések hatása a fotolumineszcencia spektrumra ............................... 68

6.1.2.3. Az implantálás és hökezelés okozta kötésszerkezeti változások ..................... 71

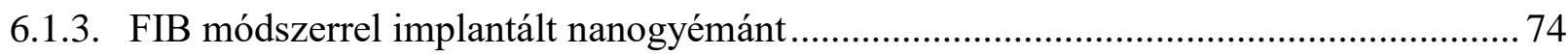

6.1.3.1. Fotolumineszcencia spektrumok …............................................................. 75

6.1.3.2. Az implantálás és hökezelés okozta kötésszerkezeti változások ..................... 77

6.1.4. Az implantációs technikákkal kialakított $N 3$ centrum emissziójának jellemzése............ 80

6.1.4.1. A szobahömérsékleten mért lumineszcencia spektrum spektrális

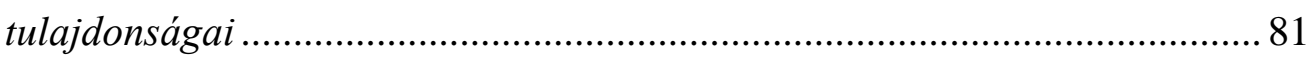

6.1.4.2. Az N3 centrum lumineszcencia spektruma alacsony hömérsékleten .............. 84

6.1.4.3. A kialakitott N3 centrum vizsgálata fotolumineszcencia gerjesztési spektroszkópiával .............................................................................. 87

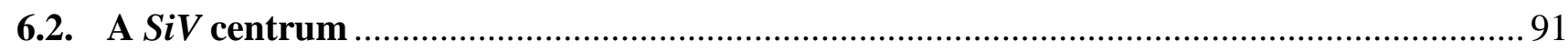

6.2.1. A $S i V$ centrum lumineszcencia spektruma nanogyémánt vékonyrétegekben .................91

6.2.2. A centrum zérusfonon vonalának (ZPL) spektrális eloszlása ...................................... 93

6.2.3. A ZPL spektrális paramétereinek meghatározása .................................................... 96

6.2.4. A spektrális paraméterek változásának vizsgálata ..................................................... 97

6.2.4.1. A maradék belsö feszültségek meghatározása a gyémánt Raman-szórási

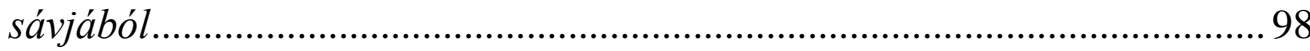

6.2.4.2. A SiV ZPL spektrális paramétereinek változása a belsö feszültséggel......... 100

6.2.4.3. A SiV ZPL spektrális paramétereinek változása az átlagos szemcsemérettel ...................................................................................... 103

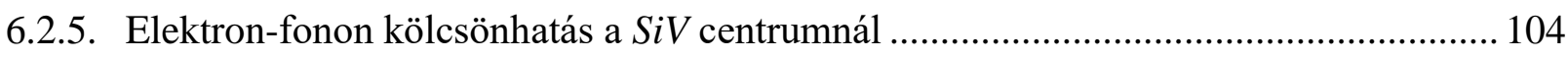




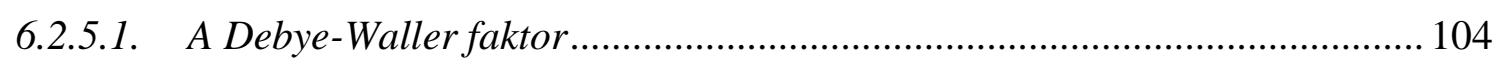

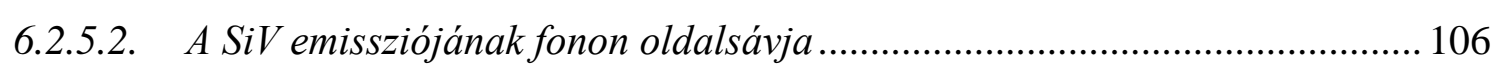

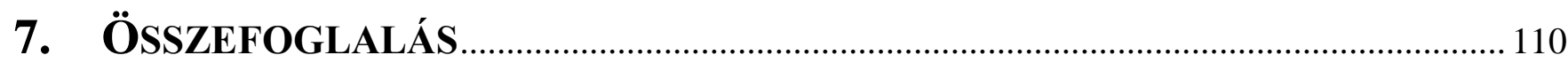

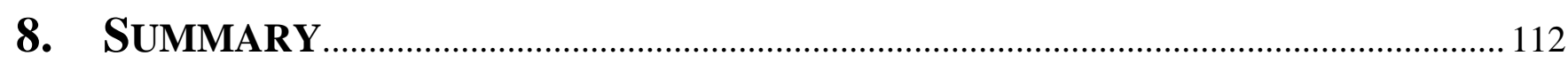

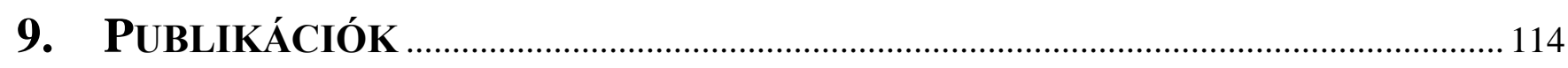

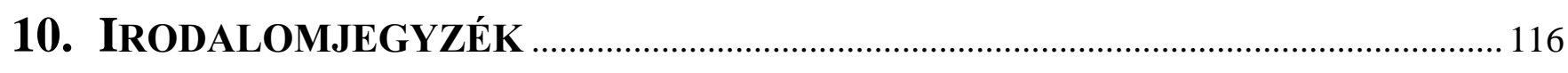

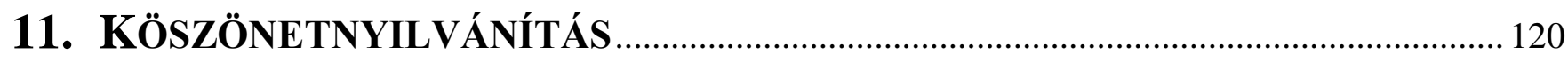

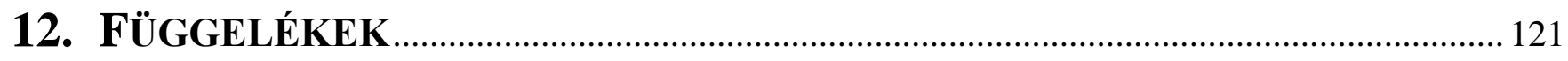




\section{Rövidítések és jelölések jegyzéke}

QIP - Quantum Information Processing, kvantum-információ feldolgozás

ZPL - Zero-Phonon Line, zérusfonon vonal

FWHM - Full Width at Half Maximum, félértékszélesség

SEM - Scanning Electron Microscopy, pásztázó elektronmikroszkópia

HPHT - High Pressure High Temperature, nagy nyomás és magas hőmérséklet eljárás

MW CVD - Microwave Assisted Chemical Vapor Deposition, mikrohullámú kémiai gőzfázisú leválasztás

ESR - Electron Spin Resonance, elektron-spin rezonancia

ED - Electric Dipole, elektromos dipólus

MD - Magnetic Dipole, mágneses dipólus

FLG - Fotolumineszcencia gerjesztési spektroszkópia

DW - Debye-Waller faktor

HR - Huang-Rhys faktor

PIII - Plasma-Immersion Ion implantation, plazmaimmerziós ionimplantáció

FIB - Focused Ion Beam, fókuszált ionnyalábos besugárzás

SRIM - Stopping and Range of Ions in Matter (számítógépes programcsomag)

TRIM - Transport of Ions in Matter (a SRIM programcsomag része)

ImageJ - ingyenes Java alapú képanalizáló program

LO - Longitudinal Optical, longitudinális optikai

TA - Transversal Acoustic, transzverzális akusztikus

SiV centrum - szilícium-vakancia hibahely a gyémántban

N3 centrum - egy szénvakancia körül elhelyezkedő 3 szubsztitúciós nitrogénatom (hibahely a gyémántban)

$N V$ centrum - egy szénvakancia és a vele szomszédos szubsztitúciós rácshelyen lévő nitrogénatom alkotta hibahely a gyémántban

GRl centrum - semleges elektromos töltésű szénvakancia (hibahely a gyémántban)

$A$ centrum -2 szomszédos nitrogénatom szubsztitúciós rácshelyen (hibahely a gyémántban)

$B$ centrum - egy szénvakancia körül elhelyezkedő 4 szubsztitúciós nitrogénatom (hibahely a gyémántban)

$C$ centrum - egy szubsztitúciós nitrogénatom a gyémántrácsban (hibahely a gyémántban) 


\section{Bevezetés}

A nanogyémánt szerkezetekben található és kialakítható, optikailag aktív hibahelyek vitathatatlanul az utóbbi évtized egyik legintenzívebben kutatott területei közé tartoznak. Alapkutatási szempontból nagy kihívást jelent a kiváló minőségü nanogyémánt struktúrák preparációja és a néhány nanométeres szemcsékben az egyedi centrumok kialakítása. Az alapkutatásokat azonban nagyban inspirálja a nanogyémánt és a benne kialakított színcentrumok gyakorlati hasznosításának széles skálája is. A szobahőmérsékleten is intenzív lumineszcencia, az emisszió hangolhatósága az ultraibolyától az infravörös hullámhosszakig, a fotodegradáció és az ún. „,villódzás” (blinking) hiánya kiváló tulajdonságok. A nanogyémántban kialakított több lumineszcencia centrum (pl. szilíciumvakancia, nitrogén-vakancia, $N 3$ centrum) egyfoton emitter, ami a kvantumoptikai alkalmazásoknál alapvető. A paramágneses centrumok pedig a kvantumkriptográfiai felhasználás lehetőségét hordozzák. A különböző hullámhosszakon lumineszkáló centrumoknak a szerkezetben történő egyidejü létrehozása és a gyémánt kiváló hővezetési tulajdonságai együttesen, akár széles tartományban hangolható szilárdtest lézerek kialakítását is lehetővé teszi.

A nanoskálájú orvosbiológia és gyógyászat területén történő alkalmazások a színcentrumokat tartalmazó gyémánt kristályok parányi méretén és biokompatibilitásán alapulnak, így ellentétben a nanocsövekkel nem vezetnek rákos sejtek kialakulásához. Ezen alkalmazások lényege, hogy a különböző színcentrumokat tartalmazó nanogyémánt kristályok különböző sejtekbe, vagy sejtszervecskékbe való bejuttatása lehetővé teszi ezen egységek három dimenziós „in vivo” nyomon követését, illetve megfelelő hatóanyagot kapcsolva az említett nanogyémánt struktúrára célzottan juttathatunk el gyógyszert a szervezet különböző részeihez, például közvetlenül rákos sejtekhez, ezzel csökkentve az egészséges sejtek károsodását és a szervezet gyógyszerterhelését. Mindezek mellett azonban talán a legjelentősebbek, a nanogyémánt színcentrumok alkalmazási lehetőségeit tekintve, azon perspektivikus tulajdonságok, melyek a kvantuminformatikához és a kvantumtitkosításhoz kapcsolódnak, és amelyek nélkül a XXI. század legnagyobb tudományos kihívása - a kvantum számítógép - megvalósítása elképzelhetetlen. Ennek egyik alapköve az úgynevezett kvantum információfeldolgozás (QIP - Quantum Information Processing), mely a kvantummechanika alapjaira épül és több gyakorlati alkalmazást foglal magába. A kvantumeszközök kialakításának egyik alapfeltétele az egyedi kvantumállapotok kialakításának és manipulálásának nanométeres skálán történő nagyon precíz kivitelezése. Mivel a fény kvantumállapota, azaz a foton eleget tesz ezen feltételeknek, emellett lehetővé teszi az információ fénysebességgel történő továbbítását alacsony zaj mellett és koherencia veszteség nélkül, így a QIP rendszerek lehetséges építőeleme lehet a jövőben a nanogyémánt. Az egyfotonok könnyen alkalmazhatóak kvantumbitekként (qubit), mivel az információ 
az egyes qubitek polarizációs állapotába kódolható. Ehhez azonban elengedhetetlen olyan, a gyakorlatban is tökéletes egyfoton emitterek kialakítása, melyek abszolút fotostabilitással rendelkeznek (nincs villódzás, vagy elsötétülés), csak egyetlen fotont emittálnak egy gerjesztési impulzus során, valamint az emittált fotonok megkülönböztethetetlenek. Ezen feltételeknek leginkább a kvantumpöttyök és a gyémántban található színcentrumok tesznek eleget. Utóbbiak előnye, hogy példa nélküli fotostabilitással bírnak, így a kvantumpöttyöknél gyakran megfigyelt „,villódzás” kevésbé jellemző rájuk, továbbá a müködésükhöz nincs szükség alacsony hőmérsékletre és előállításuk is viszonylag egyszerü.

A dolgozatban két, különböző szerkezettel rendelkező lumineszcencia centrum nanogyémánt szerkezetekben történő kialakításával és emissziójuk spektrális jellemzőinek meghatározásával foglalkozom. Ezek a lumineszcencia centrumok több, az előzőekben ismertetett alkalmazási lehetőséghez kapcsolódnak vagy már meglévő alkalmazásokhoz alternatívaként szolgálhatnak.

Az értekezés első részében egy szénvakancia körül elhelyezkedő, három nitrogénatomból álló lumineszcencia centrum, az úgynevezett $N 3$ centrum, nanogyémánt szemcsékben történő utólagos kialakításával foglalkozom különböző ionimplantációs módszerek alkalmazásával, majd részletesen analizálom a kialakított színcentrum spektrális jellemzőit. A hibahely UV-hez közeli, mélykék spektrális tartományba eső, intenzív lumineszcencia sávval rendelkezik már szobahőmérsékleten is, zérusfonon vonala $2,985 \mathrm{eV}(415 \mathrm{~nm})$ fotonenergiánál található. Emellett, az N3 centrum paramágneses, mely lehetővé teszi a qubitekhez elengedhetetlen egyfoton forrásként való alkalmazását.

Annak ellenére, hogy az említett hibahely igen gyakran előfordul a természetes gyémánt kristályokban, utólagos kialakítása a centrum szerkezetéből fakadóan nem egyszerü, főleg nanokristályban. Kísérleteink során mérsékelt ionenergiák mellett, különböző implantációs technikákat és komplex hőkezelési eljárásokat alkalmazva sikerült elöállítanunk N3 centrumot 20 nmnél kisebb szemcsemérettel rendelkező, ún. detonációs módszerrel készített nanogyémánt kristályokban. Az N3 centrum kialakítását az emissziós és gerjesztési spektrumok zérusfonon vonalának (ZPL) és fonon oldalsávjának részletes analízisével igazoltam. Az implantáció és a hőkezelés okozta kötésszerkezeti változásokat Raman-spektroszkópiai vizsgálatokkal határoztam meg.

Az értekezés második részében a nanogyémánt vékonyrétegekben, különböző paraméterek mellett kialakított, ún. szilícium-vakancia ( $\mathrm{SiV}$ ) lumineszcencia centrumok emissziójának spektrális jellemzésével foglalkozom. Összefüggést keresek a SiV centrum lokális környezetét jellemző belső feszültség és a spektrális paraméterek változása között. A nanogyémánt vékonyréteg textúráját jellemző átlagos szemcseméret és a zérusfonon vonal spektrális paraméterei közötti kapcsolatot a szemcseméret miatti tiltott fonon sáv kialakulásával és adott frekvenciájú fononok terjedésének a 
visszaszorulásával hozom összefüggésbe. Megmutatom, hogy a növekvő nyomó belső feszültség előnyösen befolyásolja a centrum emissziós intenzitásnak a zérusfonon vonalba koncentrálódó hányadát. A lumineszcencia vizsgálatok mellett a lokális belső feszültség meghatározására a gyémánt Raman-szórási sávját analizálom, míg az átlagos szemcseméretet a SEM képek alapján határozom meg.

A $S i V$ centrum zérusfonon vonala a közeli infravörös tartományban 1,68 eV (738 nm) energiánál található és így az emberi szövet optikai transzmissziós ablakába esik. A centrum egyfoton emitter és az emissziós intenzitás legalább 70\%-a a zérusfonon vonalba koncentrálódik, tehát gyenge az elektron-fonon csatolás a centrumnál. Ezek a tulajdonságok mind a biológiai, mind pedig a kvantuminformatikai alkalmazások szempontjából fontosak. 


\section{Irodalmi előzmények}

\subsection{A gyémánt, mint mátrix-anyag színcentrumok kialakítására}

A gyémánt a grafit mellett a szén legismertebb kristályos módosulata. Szobahőmérsékleten és atmoszférikus nyomáson a szén termodinamikailag stabil módosulata a grafit, míg a gyémánt metastabil. A természetes gyémánt kristályok a földkéreg alatt $200 \mathrm{~km}$-es mélységben keletkeznek, ahol a nyomás eléri a 7-8 GPa-t, a hömérséklet pedig 1670 és $1870 \mathrm{~K}$ között változik [1, 2]. A mesterséges gyémánt egyik előállítási módszere, amely során a gyémánt növesztése nagy nyomáson és magas hőmérsékleten (HPHT) történik, ezeknek a körülményeknek a másolásán alapul [1-3]. Annak érdekében, hogy a folyamat irányítható legyen, fémes ( $\mathrm{Fe}, \mathrm{Ni}, \mathrm{Co})$ katalizátorokat alkalmaznak az előállítás során. A katalizátorként használt fémek egy része beépülhet a kristályrácsba jelentős mennyiségü (akár 100 ppm) nitrogén szennyezővel együtt [1, 2]. Ehhez a folyamathoz hasonló a nanoméretű gyémánt szemcsék robbantásos eljárással történő előállítása, amikor egy irányított robbantás során a kialakuló nagy nyomást és magas hőmérsékletet használják ki a gyémánt előállítására [4]. Ezzel szemben a gázfázisból történő gyémánt előállítás, az ún. kémiai gőzfázisú leválasztás (CVD) módszere, nem a gyémántfázis keletkezéséhez szükséges termodinamikai feltételekre épül, hanem a reakció kinetikáját másolja [5]. A plazma, amely döntően atomos hidrogénből és nagy energiájú, különböző széntartalmú gyökökből, valamint ionokból épül fel, a gyémánt képződése szempontjából elönyösebb a grafittal szemben. Ez annak a következménye, hogy az atomos hidrogén elsősorban az

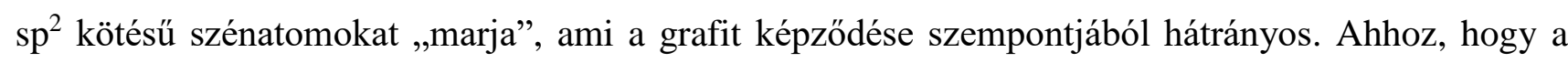
hidrogén molekula disszociációja végbemenjen, legalább 2000 K hőmérsékletre kell felmelegíteni. A különböző CVD módszerek, mint például az ívkisülés, a fütött fémszálas és a mikrohullámú plazma, eltérő technikákat használnak a megfelelő plazmahőmérséklet elérése céljából [1-3, 5]. Általánosságban kijelenthető, hogy a CVD technika növesztési folyamata jól kontrollálható, ezáltal lehetővé teszi a jó minőségü, nagy tisztaságú gyémánt előállítását. Dolgozatomban a vizsgált minták egy része mikrohullámú kémiai gőzfázisú leválasztással (MW CVD) készült.

A gyémántkristály az Fd3m tércsoportba tartozik és lapcentrált köbös szerkezettel rendelkezik. Attól függően, hogy mely kristálylapok fejlődtek a növekedés során, lehet kocka (hexaéderes), kuboktaéder, vagy oktaéder formájú. A 3.1. ábra (a) része egy oktaéderes kristályformát mutat be, összehasonlítva a hexaéderes (kocka) formával. A 3.1. ábra (b) és (c) részei a kuboktaéderes formákat mutatják be. A kuboktaéderes kristályok $\{100\}$ és $\{111\}$ kristálysíkokkal rendelkeznek, melyek az ábrán sötétkék, illetve világoskék felületekkel vannak ábrázolva.

Az utóbbi évtizedben az egyfoton emitterek és más fotonikai alkalmazások, valamint a kvantuminformatika területén végzett kutatások rámutattak a nagy tisztaságú gyémánt 
nanokristályoknak, mint mátrix-anyagnak a kiemelkedő fontosságára. Az alábbiakban a gyémánt azon tulajdonságairól lesz szó, amelyek elsősorban az előbb említett alkalmazások szempontjából relevánsak.

(a)

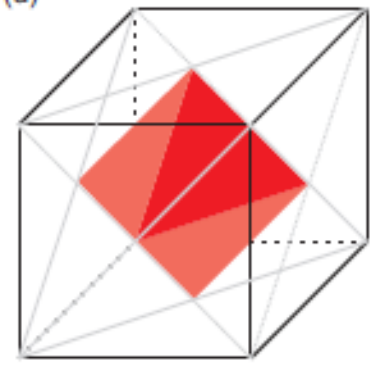

(b)

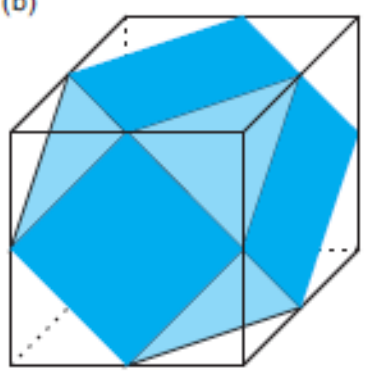

(c)

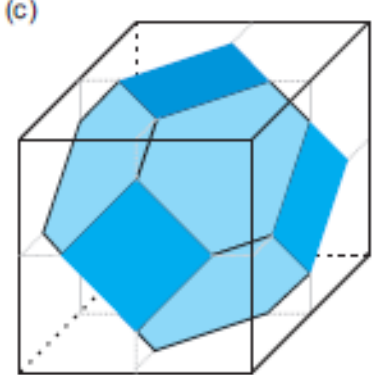

3.1. ábra: A gyémánt kristály (a) hexaéderes (fekete folytonos vonal) és oktaéderes (pirossal kitöltött rész) formája, míg (b) és (c) a gyémánt kristály kuboktaéderes formái [6].

A tiszta gyémánt egykristály a nagyon széles tilos sávjának köszönhetően transzparens a látható fény teljes és az ultraibolya sugárzás jelentős spektrális tartományába eső fény számára, ami a 230 nmnél $(5,4 \mathrm{eV})$ nagyobb hullámhosszakat jelenti. Ezzel szemben a nem tökéletes kristály, vagy azok a gyémántok, amelyek nagy koncentrációban tartalmaznak szennyezőket, különösen a poli- és a nanokristályos gyémánt esetében az optikai abszorpció felfutása a nagyszámú hibahely által generált tilos sávon belüli állapotok hatására eltolódik a kisebb energiák felé [10,11]. A gyémánt 5,5 eV széles indirekt tilos sávú félvezető. A direkt tilos sáv szélessége elérheti a 7,3 eV-ot, amely 170 nm-es hullámhossznak felel meg. Ennek a nagy tilos sávnak köszönhetően széles energiatartomány áll rendelkezésre a diszkrét, szennyezők és hibahelyek által keltett energiaszintek kialakítására. Az optikailag aktív hibahelyek, vagy hibahely komplexumok abszorpciója határozza meg a természetes gyémánt színét, ezért ezeket a hibahelyeket gyakran színcentrumoknak is nevezik. Több mint 500 optikailag aktív hibahelyet dokumentáltak eddig a gyémántban [1]. Mivel a gyémántkristályt alkotó szénatomok kisméretűek, a köztük lévő kötés nagyon erős és a kötéstávolság is viszonylag kicsi, ezért nagyméretű szennyező atomok elhelyezkedése a kristályrácsban szinte lehetetlen úgy, hogy azok ne okoznának jelentős feszültséget, ami miatt a nehéz szennyező atomokhoz köthető hibahelyek koncentrációja általában kicsi [12]. Ennek ellenére előfordul, hogy olyan extrém nehéz szennyezők is, mint a ritkaföldfémek rácshelyre épülnek be az ionimplantációt követően $[13,14]$.

Amellett, hogy széles energiatartomány áll rendelkezésre a hibahelyektől származó elektronállapotok kialakítására, a színcentrumok viselkedését befolyásolja a hozzájuk kapcsolódó elektronátmenetek fononokkal való kölcsönhatása is. A gyémánt ebben a vonatkozásban elönyös tulajdonságú mátrix, mivel a kristályrácsa viszonylag nagy energiájú rácsrezgésekkel jellemezhető. A gyémántrács fononenergia-tartománya 70 meV-tól 168 meV-ig terjed. A gyémánt Debye frekvenciája $150 \mathrm{meV}$, amely a szénatomok elméletileg meghatározott maximális rezgési frekvenciája a 
gyémántkristályban [15]. A fonon állapotsürüség, és főként annak a kis energiájú hozzájárulása, jelentősen befolyásolja az elektronátmenetek kiszélesedését a szilárd anyagokban [15], emiatt a viszonylag nagy energiájú fononok jelenléte a gyémántban, akár előnyös is lehet.

A gyémánt törésmutatója $740 \mathrm{~nm}$-es $(1,675 \mathrm{eV})$ hullámhossznál $n_{\mathrm{d}}=2,4$, ami összehasonlítva

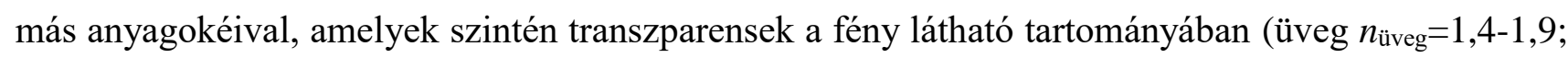
szilícium-nitrid $n_{\mathrm{SiN}}=2,02$ ), nagy értéknek számít. Ugyanakkor, ismeretesek olyan anyagok is, amelyek extrém nagy törésmutatóval rendelkeznek, mint például a gallium-foszfid $\left(n_{\mathrm{GaP}}=3,3\right)[16]$. A nagy törésmutató lehetővé teszi olyan fotonikus mikroszerkezetek - nanohuzalok [17], mikro-gyürü rezonátorok [18], fotonikus kristályok [19] - implementálását a gyémántra, amelyek jellemzően nagy törésmutatójú anyagokon alapulnak. Ezek a fotonikus szerkezetek lehetővé teszik erősítéses egyfoton források kialakítását, valamint a szerkezet méretétől és típusától függően az erős fény-anyag kölcsönhatást.

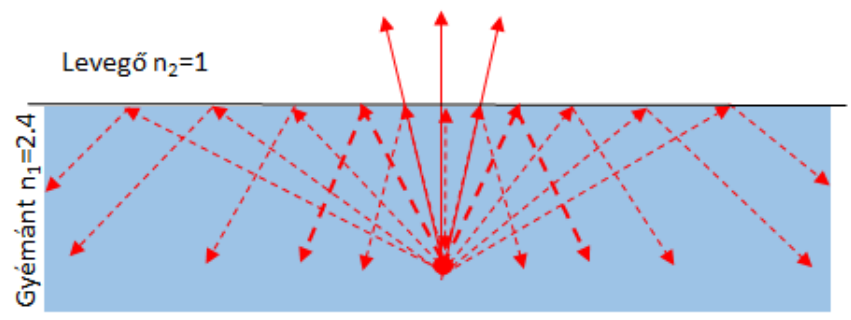

3.2. ábra: A gyémánt-levegö határfelületen bekövetkezö teljes visszaverödés sematikus ábrázolása egy lumineszkáló színcentrum esetén, ami az emissziós intenzitás jelentős csökkenését eredményezi. A vastag szaggatott vonal a teljes visszaverödés határszöge.

Az említett fotonikus szerkezetek használata nélkül ugyanakkor a gyémánt nagy törésmutatója hátrányos is lehet a különböző színcentrumok egyfoton forrásként való alkalmazása során, ahogy azt a 3.2. ábra is mutatja. A teljes visszaverődés határszöge a gyémánt-levegő határfelületen mindössze $24,6^{\circ}$, ezért a sugárzás mintázatától függően, a színcentrum fluoreszcenciájának jelentős része nem jut ki a gyémántkristályból. Még a felületre merőlegesen érkező fénynek is több mint 17\%-a visszaverődik a gyémántszerkezetbe. Szerencsére azonban a fluoreszcencia begyüjtésének hatásfoka megnövelhető azzal, hogy az adott színcentrum emissziós hullámhosszánál kisebb méretű gyémántkristályokat alkalmazunk mátrix-anyagként [49].

A gyémántra nem jellemző a kettőstörés, ami a köbös kristályrács szimmetriájának köszönhető. Egyes kristályhibáknak (mint például a diszlokációk) tulajdonítható, belső feszültség által okozott kettőstörés ugyanakkor gyakran megfigyelhető. Nemrégiben olyan kettőstörés-mentes, jó minőségü gyémántokat sikerült előállítani [20], amelyek a lézerekben intrakavitációs hőelosztóként (a gyémánt kiváló hővezető képességének köszönhetően) alkalmazhatóak. A gyémánt Raman-lézer aktív 
anyagaként is kiváló. Az utóbbi alkalmazási lehetőség szempontjából a gyémánt nagyfokú Raman-jel erősítése [ 75 GW/cm az 532 nm-es $(2,33 \mathrm{eV})$ hullámhosszú gerjesztésnél] kiemelten fontos [21].

\subsection{Nitrogént tartalmazó szennyezési centrumok a gyémántban}

A gyémánt szerkezetek vizsgálata szempontjából a különböző szennyező atomoknak, de főként a nitrogénnek, kiemelt szerepe van. A természetes gyémántkristályokat is a nitrogén szennyezők jelenléte, vagy hiánya, illetve a hozzá köthető hibahelyek atomi szerkezet alapján csoportosítják [6, 7]. A legtöbb CVD gyémántkristály a IIa alcsoporthoz tartozik, ahová az ún. „tiszta” kristályokat sorolják, melyek nem rendelkeznek karakterisztikus infravörös abszorpciós sávot adó hibahelyekkel, míg a HPHT gyémántkristályok leggyakrabban Ib típusúak. Utóbbi alcsoportra jellemző, hogy a fő szennyező a szubsztitúciós rácshelyen elhelyezkedő, izolált nitrogén atom [7].

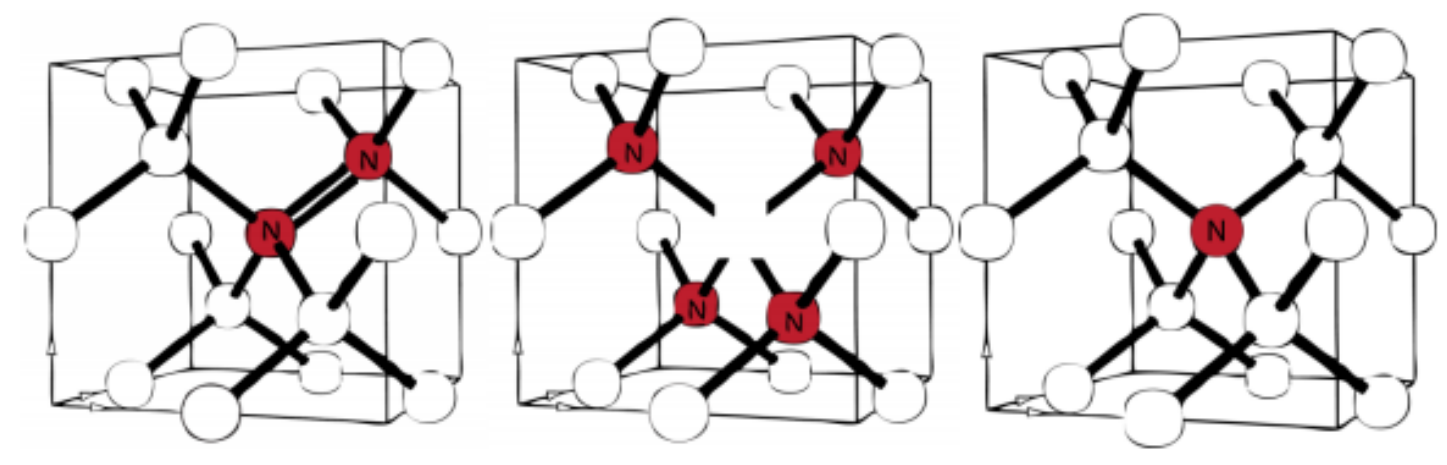

3.3. ábra: A gyémántban leggyakrabban elöforduló és nitrogénhez (piros körök) köthetö színcentrumok sematikus szerkezetei. Balról jobbra haladva az úgynevezett A centrum, B centrum és C centrum látható. Az üres körök a szénatomokat, az üres hely a szénvakanciát jelöli.

A természetes gyémánt kristályokban a nitrogén koncentrációja elérheti akár a $10^{4}$ ppm-et is $[22,1]$. Előfordulhat egyetlen szubsztitúciós atomként, illetve kettő, vagy több atomból álló aggregált formában is. A hibahely szerkezetének függvényében az adott centrumot $A, B$, vagy $C$ centrumnak nevezik (3.3. ábra). Az irodalomban használt nevezéktan egyáltalán nem nevezhető logikusnak, ugyanis az egyetlen szubsztitúciós nitrogén atomból álló hibahelyet, melynek infravörös aktív rezgése $1344 \mathrm{~cm}^{-1}$-nél található, $C$ centrumnak nevezik. A centrum paramágneses tulajdonságokkal rendelkezik és sokszor $P 1$ centrum néven is emlegetik, ami némileg megtévesztő [23]. Ezzel szemben a két egymással szomszédos szubsztitúciós nitrogén atom által alkotott hibahelyet már $A$ centrumnak nevezi az irodalom. Ez a hibahely a leggyakrabban megtalálható defektus a természetes gyémánt kristályokban. Mivel az abszorpciós sávja 4 eV (310 nm) körül található, ezért nem okoz elszíneződést a kristályokban. Az A centrum alapállapotban diamágneses, de az UV tartományba eső gerjesztéssel ionizálható $[24,25]$. A legtöbb nitrogént tartalmazó hibahelyet, amely egy szénvakanciát körülvevő négy nitrogénatomból áll, $B$ centrumként, vagy egyes irodalmakban, $B 1$ centrumként emlegetik [12]. 
A természetben azok a kristályok, amelyekben a nitrogén szennyező többségében $B$ centrum formában van jelen, nagyon ritka. Általában a legtöbb természetes kristály egyidejüleg tartalmazza az $A$ és $B$ centrumokat, illetve az úgynevezett $N 3$ centrumot, melyről a későbbiekben részletesebben lesz szó.

Az előbbiekben említett hibahelyeken kívül egy további formája a nitrogén szennyezőnek, amely nagyon gyakran előfordul mind a természetes, mind pedig a mesterségesen előállított gyémánt szerkezetekben, az úgynevezett nitrogén-vakancia $(N V)$ centrum. A centrum egy szubsztitúciós rácshelyet elfoglaló nitrogén atomból és a vele szomszédos szénvakanciából épül fel (3.4 ábra (a) része).
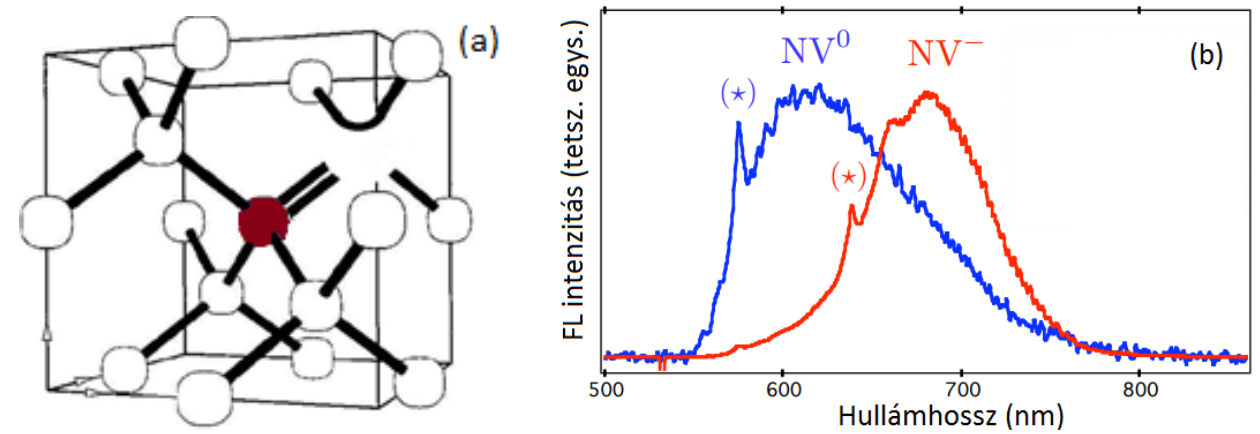

3.4. ábra: A nitrogén-vakancia centrum (a) szerkezetének modellje és (b) fotolumineszcencia spektrumai a két különbözö töltésü állapotban. A zérusfonon vonalat ( $\left.{ }^{\star}\right)$ jelöli az ábrán [26].

Az $N V$ centrum a $C_{3 v}$ szimmetriacsoporthoz tartozik és két különbözö, negatívan töltött és semleges állapotban fordul elö. A negatívan töltött hibahely $\left(N V^{-}\right)$optikai zérusfonon vonala $635 \mathrm{~nm}$ $(1,945 \mathrm{eV})$, míg az elektromos töltéssel nem rendelkező $\left(N V^{0}\right)$ centrum zérusfonon vonala $575 \mathrm{~nm}$-nél $(2,156 \mathrm{eV})$ található. A két különböző állapotban a centrum eltérő optikai (3.4.(b) ábra) és mágneses tulajdonságokkal rendelkezik. Az utóbbi időben a kutatások elsősorban az $N V^{-}$centrumra fókuszáltak, amely hibahely az egyedi fizikai tulajdonságainak köszönhetően jelentős szerephez juthat olyan fontos területeken, mint a kvantuminformatika, orvosbiológia, vagy a nanoszenzorika [17, 27-29]. Itt fontos megjegyezni, hogy az $N V^{-}$centrum egyedi optikai tulajdonságaira épülő alkalmazási lehetőségek tényleges gyakorlati megvalósítása nagy kihívás elé helyezi a kutatókat és fejlesztőmérnököket. Ennek a legfőbb oka a centrumra jellemző erős elektron-fonon csatolás, amely intenzív fonon oldalsávként jelentkezik a centrum emissziós spektrumában. A zérusfonon vonalba koncentrálódó emissziós intenzitás még alacsony hőmérsékleten is csak 3\% körüli a centrum teljes emissziójához képest [16].

\subsubsection{Az $N 3$ centrum atomi szerkezete és kialakítása gyémántban}

A gyémántban található nitrogén szennyezéshez kapcsolódó, kiváló fizikai tulajdonságokkal (egyfoton emitter, intenzív ZPL, mélykék emisszió, paramágneses centrum) rendelkező N3 lumineszcencia centrum eddig kevesebb figyelmet kapott a gyémántban kialakítható centrumok között. 
Ennek egyrészt az az oka, hogy nem sikerült egyértelmüen igazolni az N3 centrum kialakítását nanogyémántban, másrészt az utóbbi időszakban favorizált orvosbiológiai alkalmazásra nem előnyös. Az N3 centrum emissziós és abszorpciós zérusfonon vonala 415 nm-nél (2,985 eV) található [1]. A centrum három, szubsztitúciós helyen lévő nitrogén atomból áll, amelyek egy szénvakancia körül helyezkednek el (3.5. ábra). Sokáig azonban nem volt egyértelmű az N3 centrum szerkezete [30]. A korai polarizációs mérésekből megállapították, hogy a 2,985 eV-nál jelentkező sávhoz tartozó szerkezet az <111> kristálytengelyen helyezkedik el és az átmenet egy nem degenerált és egy kétszeresen degenerált elektronállapot között megy végbe [31]. Később a nem tengely irányú feszültségmérésekből az is kiderült, hogy a nem degenerált állapot energetikailag az alacsonyabb [32]. A további vizsgálatok során arra a megállapításra jutottak, hogy a $P 2$ néven ismert ESR (elektron-spin rezonancia) centrum megegyezik a 2,985 eV-os optikai sávhoz köthető szerkezettel [31], viszont magáról a hibahely szerkezetéről csak később alakult ki a pontos kép. A szénvakancia miatt a hibahely szerkezetében található szakadt kötések magyarázzák a centrum paramágneses viselkedését. A szerkezeti modell alapján számolt és a kísérletileg meghatározott elektron-spin rezonancia paraméterek összhangban voltak a 2,985 eV-os abszorpciós sáv változásával [34], ami a centrum szerkezetére vonatkozó modellt (3.5. ábra) megerösítette.

Szemben egyes hibahelyekkel, az N3 centrum számos mesterségesen előállított makroszkopikus gyémántkristályban is megfigyelhető. A centrum elsősorban az úgynevezett HPHT technikával előállított gyémántokra jellemző. Az említett módszerrel különösen nagy mennyiségü centrumot tartalmazó minták állíthatók elő, ha azokat a növesztés során ciánnal adalékolják [1]. A HPHT növesztési módszer mellett, a mesterséges gyémántnövesztés másik igen elterjedt technikájával, az úgynevezett MW CVD-vel készült egykristályokban is kimutatták az N3 centrum jelenlétét [35]. Az N3 centrum létrejöttének mechanizmusát a [36] irodalomban tárgyalják részletesen.

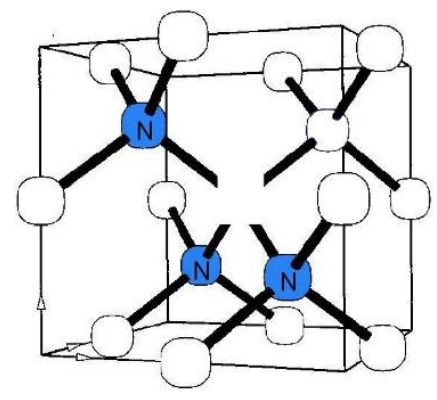

3.5. ábra: Az N3 centrum atomi szerkezetének sematikus képe. Az üres körök a szénatomokat, a kékek a nitrogént jelentik, míg a szénvakancia pedig a négy szakadt kötésnél helyezkedik el [33].

N3 centrumot utólag is ki lehet alakítani a gyémántkristályban. Ennek egyik módja, ha a nitrogént tartalmazó kristályt elektronbesugárzásnak tesszük ki [37]. N3 centrum utólagos kialakítása lehetséges úgy is, ha közvetlenül nitrogént juttatunk be a szerkezetbe ionimplantálás útján. Az 
irodalomban alkalmazott implantálási dózis $10^{10}$ és $10^{18}$ ion $/ \mathrm{cm}^{2}$ között, míg az ionenergia a néhány 10 keV-tól egészen $100 \mathrm{MeV}$-ot meghaladó energiák között változik. Mindkét esetben az implantálást követő utólagos hőkezelési folyamatok kedvezően hatottak a komplex defektcentrum kialakulására [38-40].

A makroszkopikus gyémántkristályokban a természetes folyamat során kialakult, illetve mesterségesen kialakított N3 centrummal kapcsolatos nagyszámú publikációval szemben, alig található információ az irodalomban a nanoméretű gyémántkristályokra vonatkozó eredményekröl. Ennek nagy valószínüséggel az az oka, hogy a nanoméretű kristályokban sokkal kisebb valószínűséggel alakulnak ki a több nitrogént tartalmazó komplex centrumok, ugyanis a szerkezeti tulajdonságok, illetve a méretből fakadó korlátok miatt a nitrogén migrációs modellek [36] hatékonysága is csökken.

Nanoméretű gyémántban a 415 nm-es $(2,985$ eV) emissziós sávot először a 90-es évek második felében kezdték vizsgálni [41, 42]. Ezekben a publikációkban olyan detonációs módszerrel készült gyémántkristályok emissziós tulajdonságait vizsgálták, melyek szemcsemérete 2-10 nm között változott. Mindkét publikációban az emissziós spektrum 400-500 nm közé eső tartományában szerkezettel rendelkező emissziós sávot tapasztaltak, amely hasonlított a tömbi gyémántkristályban vizsgált $N 3$ centrum emissziós sávjához. Annak ellenére, hogy a szobahőmérsékleten mért spektrumok szerkezete kevésbé hangsúlyos, mint a tömbi gyémánt esetében, az alak és hullámhossztartomány tekintetében elfogadható egyezést tapasztaltak. Az alacsony hőmérsékleten végzett vizsgálatoknál [41] pedig jól látható, hogy egyes finomszerkezetek egybeesnek a nagyméretű kristályokban detektált, az N3 centrumhoz köthető emissziós sáv finomszerkezetével. Némileg „gazdagabb” szerkezettel rendelkező emissziós sávot detektáltak a későbbiekben vizsgált, 3-6 nm szemcsemérettel rendelkező nanoméretű gyémántkristályok esetében [43]. Ezeknél a vizsgálatoknál már jól elkülöníthető a centrum zérusfonon vonala, illetve a fonon oldalsáv egyes finomszerkezetei, bár meg kell jegyezni, hogy a spektrum rossz jel/zaj aránya nem teszi lehetővé a további részletes analízist.

Általánosságban kijelenthető, hogy jelenleg kevés információval rendelkezünk a nanoméretü gyémánt szerkezetekben vizsgált N3 centrumra vonatkozóan. Emellett fontos megjegyezni, hogy mindeddig nem születtek eredmények az N3 centrum nanoméretü kristályokban történt utólagos kialakításáról, főleg annak ismeretében, hogy a természetes kristályokban leggyakrabban előforduló hibahelyek utólagos kialakítása nanoszerkezetekben már számos esetben megoldott [44-46].

\subsubsection{Az $N 3$ centrumok fotolumineszcencia tulajdonságai}

Ebben a részben elsősorban a tömbi gyémántban kialakított N3 centrumok fotolumineszcenciájáról lesz szó. Nanogyémánt esetében csupán néhány publikációban számolnak be 
az N3 centrum fotolumineszcencia tulajdonságainak vizsgálatáról [42, 43]. Ezek az eredmények elsősorban az emissziós spektrumra vonatkoznak, amelyeket majd a 3.2.2.3. fejezetben részletezek. Először a fotolumineszcencia rezonáns és nem rezonáns gerjesztéséről írok, amit az N3 centrumok gerjesztési és abszorpciós spektrumainak ismertetése követ, majd ezután kerül sorra a fotolumineszcencia spektrum részletes jellemzése. A fejezet legvégén a zérusfonon vonal spektrális jellemzőinek és a fonon oldalsávnak a bemutatása következik.

\subsubsection{A fotolumineszcencia rezonáns és nem rezonáns gerjesztése}

A lumineszcencia, mint fizikai jelenség, nem más, mint az anyag hőmérsékleti sugárzása feletti többletemissziója. A lumineszcencia spektrum pedig a többletemisszió hullámhossz szerinti eloszlása. A lumineszcenciát különböző módon lehet gerjeszteni, így optikai gerjesztés esetén fotolumineszcenciáról beszélhetünk. A dolgozatomban bemutatásra kerülö kísérleti eredményeket optikai gerjesztéssel kaptam, ezért a dolgozatban csak a fotolumineszcenciára fókuszálok. A lumineszcencia érzékenysége miatt rendkívül előnyös módszer színcentrumok vizsgálatára. Gyémántszerkezetekben a vizsgálni kívánt színcentrumokat tekintve a lumineszcencia spektroszkópia más optikai módszerekhez viszonyítva azzal a rendkívül fontos előnnyel rendelkezik, hogy lehetővé teszi az 1 ppm-nyi, vagy annál is kisebb koncentrációban jelen lévő szennyezők vizsgálatát [47].

A lumineszcencia gerjesztése az alkalmazott fény fotonenergiájának függvényében lehetséges pl. centrumon belüli gerjesztéssel. Ha a folyamat során az elektronok a defektcentrumok alapállapotaiból a gerjesztett állapotaiba kerülnek, akkor rezonáns gerjesztésről beszélünk. A fotolumineszcencia gerjesztése más fotonenergiákkal a defektcentrumok nem rezonáns gerjesztéséhez vezet. A tilos sávval rendelkező szilárd anyagoknál a fény abszorpciója lehetséges:

a) a vegyérték sáv és vezetési sáv közötti abszorpció útján, vagyis sáv-sáv átmenettel;

b) a hibahely által létrehozott elektronnívó és a vegyérték, vagy vezetési sáv közötti átmenettel, vagyis lokalizált állapotok és sávok közötti átmenettel;

c) a defektcentrum alap és gerjesztett állapotai közötti átmenettel a tilos sávon belül;

d) a tilos sávban található, különböző defektcentrumok lokalizált állapotai közötti átmenettel.

A 3.6. ábra (a) része sematikus képen mutatja egy defektcentrum nem rezonáns gerjesztését, amikor az elnyelt fény fotonjai $\left(h v_{e x}\right)$ a centrum alapállapotából a vezetési sávba gerjesztenek elektronokat, ahonnan a töltéshordozók a termalizációt követően nem sugárzó átmenettel befogódnak a centrum legalacsonyabb gerjesztett állapotába. Ebből a gerjesztett állapotból sugárzó rekombináció útján $h v_{e m}$ energiájú fotonok kibocsátásával alapállapotba relaxálnak. A 3.6. ábra (b) része egy olyan defektcentrum nem rezonáns gerjesztését mutatja, amikor a centrum a legalacsonyabb energiájú gerjesztett állapotából az alapállapotba történő átmenet tiltott. A nem megengedett dipólátmenet miatt 
a rekombináció végbemehet a centrum magasabb gerjesztett állapotából az alapállapotba $h v_{e m}$ fotonenergiájú fény kibocsátásával. A lumineszcencia átmenet tehát nem feltétlen a centrum legkisebb energiájú gerjesztett állapotából az alapállapotba történik.
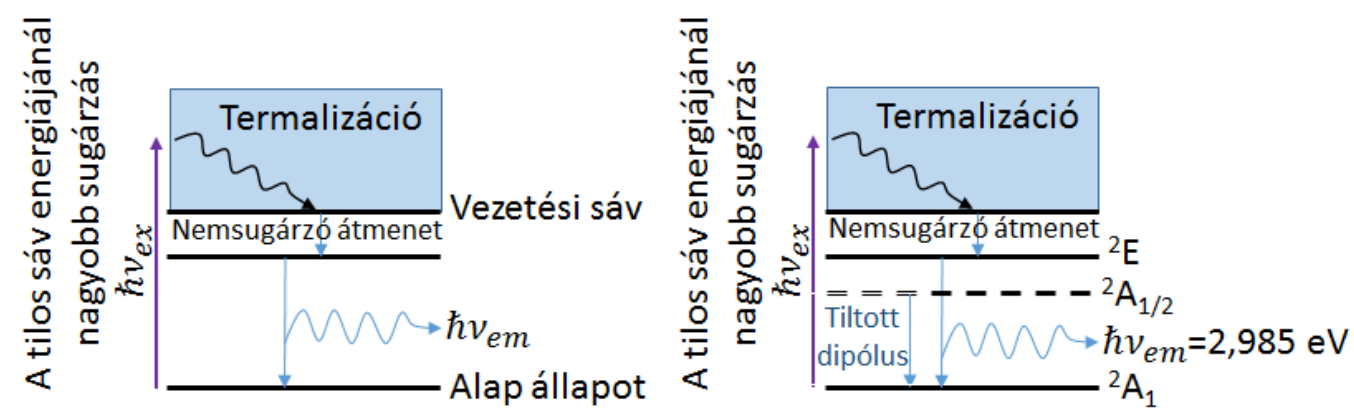

3.6. ábra: Egy defektcentrum nem rezonáns gerjesztésének és az azt követö relaxációs folyamatának sematikus ábrázolása (a) a termalizációt követöen a centrum első gerjesztett állapotából az alapállapotba történik az átmenet hvem energiájú foton kibocsátásával (b) a termalizációt követően az átmenet a centrum második gerjesztett állapotából az alapállapotba történik sugárzó rekombinációval, ahogy az az N3 centrumrendszernél feltételezhetö [49].

Abban az esetben pl., ha az átmenet a legalacsonyabb gerjesztett állapot és az alapállapot között hosszú sugárzási élettartammal rendelkezik, vagy tiltott a hibahely szimmetriája miatt, végbemehet egy magasabb gerjesztett állapotból is. Egyes szerzők ezt a modellt javasolták az N3 optikai centrum esetében is, mely trigonális szimmetriával rendelkezik [52,49] és a sugárzásos lecsengés a második gerjesztett ${ }^{2} \mathrm{E}$ állapotból történik, ahogy az a 3.6. ábra (b) részén látható. A modell alapja, hogy ugyanazon hibahelyszerkezethez (esetünkben a szénvakancia körül elhelyezkedő 3 db szubsztitúciós nitrogén atom: $V-N_{3}$ ) több optikai átmenet is tartozik [55], hasonlóan a $G R$ (szénvakancia) hibahelyhez, ahol a különböző optikai átmeneteket GR1-GR8 között jelölik [48]. Az N3 centrum 2,985 eV-nál jelentkező domináns optikai átmenetén kívül, a 2,596 és 3,7 eV energiájú átmenetek is ugyanazon a $V-N_{3}$ szerkezethez rendelhetőek. Míg a kisebb energiáknál jelentkező az N2 optikai átmenethez, addig a nagyobb energiáknál jelentkező az N4-hez tartozik. Előbbi egy elektron felgerjesztését jelenti egy a szénatomon lokalizált $a_{1}$ pályáról egy másik, a vezetési sávhoz közel eső $a_{1}^{*}$ sekély csapda nívóra, mely a vakancián kívül lokalizált. Az $N 2$ esetében az elektronátmenet a nitrogén atomon lokalizált $e$ pályáról történik [55].

\subsubsection{Az $N 3$ centrum lumineszcenciájának gerjesztési spektruma}

Ahhoz, hogy kiderítsük, hogy az adott hibahely a gyémántban optikailag gerjeszthető-e, először érdemes megvizsgálni a centrum fényabszorpciós tulajdonságait. Ha a fény (foton) abszorbeálódik, akkor annak energiája gerjeszt egy átmenetet két elektronnívó között, amely folyamat általában az 
alapállapotból indul. A fényintenzitás csökkenése, amely akkor jelentkezik, ha a fénysugár egy abszorbeáló közegen halad keresztül a Lambert-Beer törvénnyel írható le [50]:

$$
I(v)=I_{0}(v) \times e^{-[a(v) l]},
$$

ahol $I_{0}(v)$ a transzmittált fény intenzitása abszorbeáló részecskék nélkül, $a(v)$ a közeg abszorpciós koefficiense $v$ frekvenciájú fény esetében, $l$ pedig a fény által megtett úthossz a mintában. Az integrális abszorpciós koefficiens összefüggésben van az átmenet hatáskeresztmetszetével:

$$
\int a(v) d v=N \sigma
$$

ahol $N$ az abszorbeáló részecskék száma, $\sigma$ pedig az abszorpciós hatáskeresztmetszet. Az abszorpciós hatáskeresztmetszet összefüggésben van a spontán emisszió $A_{b a}$ Einstein-koefficiensével:

$$
\sigma(v)=A_{b a} \frac{g_{b} c^{2} g\left(v-v_{0}\right)}{g_{a} 8 \pi n^{2} v^{2}}
$$

ahol $g_{a}$ és $g_{b}$ az $a$ és $b$ nívók degeneráltsági foka, a $g\left(v-v_{0}\right)$ függvény pedig a vonalalakot határozza meg. Inhomogén vonalkiszélesedés esetében a vonalalak Gauss görbe alakú és $g\left(v-v_{0}\right)$ a következő módon adható meg:

$$
g\left(v-v_{0}\right)=\frac{2 \sqrt{\ln 2}}{\sqrt{\pi} \Delta v} \exp \frac{-4 \ln 2\left(v-v_{0}\right)^{2}}{(\Delta v)^{2}}
$$

Az abszorpciós sáv maximumánál $\left(v=v_{0}\right), g(v)=0,939 / \Delta v$, ahol $\Delta v$ a félértékszélesség. Alkalmazva a (3.2.) és (3.4.) egyenleteket, az abszorpciós spektrumból meghatározható az abszorpciós hatáskeresztmetszet és a sugárzó átmenet lecsengési aránya. Egy átmenet oszcillátor erőssége $f_{a b}$, amely összefüggésben van az integrális abszorpciós koefficienssel, a következő módon írható fel az elektromos dipól (ED):

$$
\int a(v) d v=N \frac{e^{2}}{4 \pi \varepsilon_{0} m c}\left[\left(\frac{E_{l o c}}{E}\right) \frac{1}{n}\right] f_{a b}(E D),
$$

illetve a mágneses dipól (MD) átmenet esetében [124]:

$$
\int a(v) d v=N \frac{e^{2}}{4 \pi \varepsilon_{0} m c} f_{a b}(M D) .
$$

Egy adott emissziós sáv gerjesztési spektruma megmutatja, hogy melyek azok az optikai átmenetek, amelyek hatékonyak az adott emisszió gerjesztése szempontjából. Az abszorpciós spektrum az adott fotonenergia-tartományban az összes optikai átmenetet tartalmazza, míg a gerjesztési spektrum csupán az adott emisszió szempontjából hatékony optikai átmeneteket. Tehát a gerjesztési spektrum az adott emissziós centrum jellemzője. A gerjesztési spektrum felvétele során a gerjesztő fény hullámhosszát változtatva mérjük az elöre megválasztott emisszió intenzitását. A gerjesztési spektrum pedig az emissziós intenzitás a gerjesztő hullámhossz (fotonenergia) függvényében. Fontos megjegyezni, hogy a gerjesztő fény intenzitására minden gerjesztő fotonenergiánál korrigálni kell a spektrumot. Az emissziós intenzitás a következő módon adható meg: 


$$
I_{e m}(v)=I_{0}(v) \times q \times\left(1-e^{-a(v) l}\right),
$$

ahol $q$ a lumineszcencia folyamat kvantumhatásfoka, a többi szimbólumot pedig már korábban definiáltam. A lumineszcencia kvantumhatásfoka egyenlő az emittált és abszorbeált fotonok arányával $[50]$.

Annak kiderítésére, hogy az adott hibahely milyen fotonenergia-tartományban gerjeszthető jó hatékonysággal, először meg kell vizsgálnunk a centrum fényabszorpcióját. Azonban az abszorpció mérése azokon a mintákon, amelyek nagyon vékonyak, vagy hordozóra lettek leválasztva, továbbá amelyekben a centrumsürüség nagyon kicsi, kísérletileg nehezen kivitelezhető. Viszont ahelyett, hogy a direkt abszorpciót detektálnánk, lehetőség van arra, hogy a hullámhossz változtatásával gerjesszük a vizsgálni kívánt centrumot és mérjük a lumineszcencia intenzitásának változását. Feltételezve, hogy szaturáció nem jelentkezik, a fluoreszcencia intenzitása arányos lesz az abszorbeált fény intenzitásával. A leírt módszert fotolumineszcencia gerjesztési spektroszkópiának (FLG) nevezik [49].

Nem rezonáns fotogerjesztést követően a keletkezett elektron-lyuk párok egy gyors relaxációs folyamatot követően fotolumineszcencia révén egy alacsonyabb energiájú állapotba jutnak, ezáltal egy kvázi-termikus egyensúlyi állapotba kerülnek a kristályráccsal. Azt várjuk, hogy az elektron-lyuk párok „elfelejtik” hogy milyen módon lettek gerjesztve a relaxációs folyamatot megelőzően, ezért az emissziós intenzitás nem feltétlenül kellene, hogy korrelációt mutasson az abszorpciós koefficienssel. A kérdés kvantitatív vizsgálata szempontjából írjuk fel az emissziós intenzitás $\left(I_{e m}\right)$ és a gerjesztési intenzitás $\left(\mathrm{I}_{\mathrm{ex}}\right)$ közötti kapcsolatot a következőképp:

$$
I_{e m}=P_{a b s} P_{r e l} P_{e m} I_{e x},
$$

ahol $P_{a b s}$ - a beeső foton elnyelésének valószínűsége a minta által; $P_{r e l}$ - annak a valószínüsége, hogy a fotogerjesztett elektron-lyuk párok az emissziós állapotba relaxálnak, $P_{e m}-$ az elektron-lyuk pár relaxációt követő, sugárzásos rekombinációjának a valószínűsége. Míg $P_{e m}$ feltételezhetően konstans az FLG kísérletben, addig $P_{\text {rel }}$ erősen függ az elektron-lyuk pár energiájától. Általában a hibahely mentes félvezetök esetében, az elektron-lyuk párok föleg elektron-fonon kölcsönhatás révén relaxálnak. Azonban, ha a szerkezetben sok a hibahely, az elektron-lyuk párok többsége a hibahelyeken csapdázódik és nemsugárzó folyamat révén rekombinálódik. Mindkét esetben a folyamat valószínűsége függ az elektron energiájától. Ebből kifolyólag általában nem lehetséges korrelációt megállapítani az $I_{e m}$ és $P_{a b s}$ között, anélkül, hogy tudnánk a hibahelyeken való csapdázódás és az elektron-fonon relaxációs folyamatok relatív arányát. Azonban vannak olyan kivételes esetek, melyeknél a nemsugárzó rekombináció elhanyagolható, összehasonlítva az elektron-fonon kölcsönhatás során bekövetkező szórással [51]. 
Az FLG spektroszkópiával kapott irodalmi [52-54] eredmények azt mutatják, hogy a tömbi gyémántkristályban található $N 3$ centrum alapvetően két fotonenergia-tartományban gerjeszthető. Az első tartomány, mely a zérusfonon vonalhoz közvetlenül kapcsolódik és a centrumon belüli rezonáns gerjesztésnek felel meg, 3,0 és 3,6 eV fotonenergiák között található, ahogyan ezt a 3.7. ábra is mutatja. Az említett tartomány szerkezetét és alakját tekintve a ZPL-hez képest közel tükörszimmetrikus az emissziós spektrummal. Ennek megfelelően a - 3.2.2.3. részben bővebben tárgyalt - emissziós spektrumban megfigyelt fononszerkezetek egy része beazonosítható a gerjesztési spektrum rezgési oldalsávjában is. Ezekhez tartoznak a 90, 158, 245 és $315 \mathrm{meV}$ fononszerkezetek (a rezgési energiáknak megfelelö A, B, C és D csúcsok, valamint ezek '-fal jelölt párjai a 3.7. ábrán láthatóak) $[1,52-54]$.

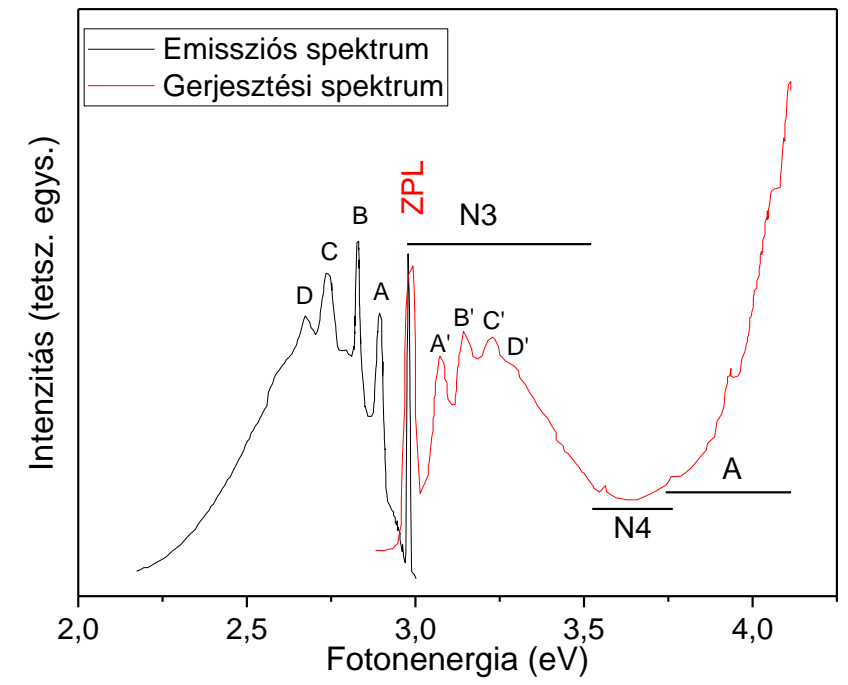

3.7. ábra: A tömbi gyémántkristályban, folyékony nitrogén hömérsékleten mért N3 centrum emissziós és gerjesztési spektrumai [52].

A második tartomány, amely jellemzően a gerjesztési spektrum $\sim 3,6 \mathrm{eV}$ fölötti részét jelenti, kevésbé strukturált. A gerjesztési spektrum legkisebb intenzitású tartományánál látható lokális csúcs $\sim 3,6 \mathrm{eV}$ körül az előző részben említett $N 4$ optikai átmenethez tartozik. A nagyobb energiák felé haladva az emissziós intenzitás hirtelen növekedni kezd és növekedés kitart egészen a vizsgált tartomány széléig, azaz 4,2 eV-ig. Az FLG spektrum ezen tartománya az A centrumhoz rendelhető és az N3 centrum gerjesztése ebben a fotonenergia-tartományban feltételezhetően energiatranszfer útján történik.

\subsubsection{Az $N 3$ centrum lumineszcencia spektruma}

A 3.7. ábrán a gyémánt kristályban található $N 3$ centrum gerjesztési spektruma mellett az emissziós spektrumot is feltüntettem $[12,56,57]$. Az N3 centrum emissziója, hasonlóan a gyémántban található számos optikai centrumhoz, Mössbauer-típusú optikai spektrummal jellemezhető, amely jól 
feloldott zérusfonon vonalból és annak fononasszisztált ismétlődéséből tevődik össze. Ezen szerkezetekre jellemző, hogy még magasabb hőmérsékleteknél is viszonylag jól elkülönülnek [56]. A Mössbauer-típusú optikai spektrumok jellemzőiről bővebben a [12] irodalomban olvashatunk.

Az N3 centrum esetében az emissziós spektrum keskeny zérusfonon vonala 2,985 eV-nál jelentkezik és a kisebb energiák felé haladva ennek ismétlődése látható, mely a rezgési oldalsávot alkotja. Utóbbi legalább két különböző energiájú ( $88 \mathrm{meV}, 156 \mathrm{meV}$ ) sorozatból épül fel, melyek közül a dominánsabb $88 \mathrm{meV}$ fonon energiával ismétlödik. Az ily módon átlapoló fononasszisztált csúcsokból álló széles oldalsáv 2,2 eV körül cseng le [12,57].

A zérusfonon vonal a centrum tiszta (fonon kölcsönhatás nélküli) elektronátmenete, amely keskeny sáv formájában jelentkezik az abszorpciós, vagy az emissziós spektrumban. Sokkal keskenyebb a fononasszisztált átmeneteknél (rezgési oldalsávval). A ZPL-be koncentrálódó emissziós intenzitás színcentrumok esetében összemérhető, vagy sokkal kisebb a fonon oldalsáv intenzitásánál. Az egyik legfontosabb feltétele annak, hogy egy színcentrum a gyakorlatban is használható legyen pl. egyfoton emitterként az, hogy a lumineszcencia minél nagyobb része a keskeny zérusfonon vonalba koncentrálódjon [6].

\subsubsection{Az N3 centrum zérusfonon vonalának spektrális jellemzői}

A korábbi vizsgálatok során kísérletileg megállapítást nyert, hogy az N3 centrumnak mind a zérusfonon vonala, mind pedig annak kiszélesedése némileg változik a különböző mintákban [12, 15, $52,57]$. Az is kiderült, hogy a zérusfonon vonal relatív intenzitása a fonon oldalsávhoz képest, szintén változik az egyes mintákban. Az egyébként jól emittáló mintákban a zérusfonon vonal intenzitása kisebb a fonon oldalsáv intenzitásához képest. Ez utóbbi jelenség nemcsak az emissziós spektrumban, hanem az egyes abszorpciós spektrumokban is megfigyelhető, így aztán nem valószínü, hogy a nem fononasszisztált sugárzás önabszorpciója okozná [56].

A zérusfonon vonal kiszélesedése és pozíciója is változik a hőmérséklettel. Míg az utóbbi 2,972,99 eV között változik a hőmérséklet csökkenésével, addig az inhomogén vonalkiszélesedése egyes mintáknál kevesebb, mint 1,5 meV is lehet [1, 58]. Emellett az $N 3$ centrum zérusfonon vonalának pozíciója érzékeny a kristályhibák miatt fellépő belső feszültségre, ami egy tengely mentén ható külső nyomással végzett kísérletekböl is kiderült. A 0 és 1,5 GPa nyomás között az $<111>$ tengely irányban végzett kísérletek azt mutatják, hogy az említett tartományban az N3 centrum zérusfonon vonalának pozíciója -6 és $13 \mathrm{meV}$-al tolódott el. A mínusz előjel az eltolódás irányát mutatja a 2,985 eV-hoz képest [56].

Jelentősen kevesebb információ áll rendelkezésre az MW CVD és detonációs módszerrel kialakított $N 3$ centrumok zérusfonon vonalát illetően. A legtöbb esetben az N3 centrum ZPL-je a tömbi 
gyémántban tapasztaltakhoz hasonlóan 2,985 eV-nál detektálható [35]. Az MW CVD mintákban vizsgált $N 3$ centrumok zérusfonon vonalának kiszélesedése nagyon érzékeny a belső feszültségre [1, 59]. Ami pedig a robbantásos eljárással előállított nanoméretü gyémántkristályokban vizsgált $N 3$ centrumokat illeti, a legtöbb esetben a ZPL egyáltalán nem, vagy csak alig detektálható. A kétfotonos gerjesztéssel vizsgált, átlagosan $4 \mathrm{~nm}$-es szemcsemérettel rendelkező nanokristályokon - alakját tekintve - a tömbi kristályban detektált N3 centruméhoz nagyon hasonlító emissziós sávot mértek [42]. Bár a spektrumban a ZPL nem elkülöníthető, az emissziót az V-N $\mathrm{N}_{3}$ hibahelyszerkezettel magyarázták. UV (4,856 eV) gerjesztést alkalmazva hasonlóan kisméretủ gyémánt nanoszerkezeteken, 410 és 460 nm között jelentkező emissziós sávot detektáltak. Annak ellenére, hogy a detektált spektrum jel-zaj viszonya rossz, elég jól beazonosítható a 417 nm (2,973 eV) körül jelentkező kis intenzitású ZPL [43]. Mindkét esetben a spektrum kevésbé karakterisztikus jellegét a centrumot tartalmazó kristályszerkezet nagy hibahely koncentrációjával magyarázták, amely az MW CVD módszerrel előállított minták esetében is az emissziós spektrum degradációját okozza, bár jellemzően kisebb mértékben.

\subsubsection{Elektron-fonon csatolás az $N 3$ centrumnál}

A gyémánt kristálya viszonylag könnyü szénatomokból épül fel, melyek erős kovalens kötéssel kapcsolódnak egymáshoz, ezért a gyémánt magas Debye hőmérséklettel (2220 K) rendelkezik. Ez azt eredményezi, hogy az elektron-fonon csatolás a gyémántrácsban nem mutat jelentős változást még szobahőmérsékleten sem, tehát a szobahőmérséklet még ,alacsony” hőmérsékletnek számít a gyémánt esetében. Ez az oka annak, hogy a gyémántban található legtöbb színcentrum emissziója megőrzi a Mössbauer-típusú optikai spektrum jellegét még magasabb hőmérsékleten is. Az irodalomban egyszerre használják a Debye-Waller (DW) faktort és a Huang-Rhys (HR) faktort is az elektron-fonon csatolás erősségének a jellemzésére. Míg az előbbi az adott színcentrum zérusfonon vonal integrális intenzitásának az aránya a teljes intenzitáshoz képest, addig az utóbbi a következő kifejezéssel határozható meg: $\frac{I_{Z P L}}{I}=\exp (-S)$, ahol $S$ a Huang-Rhys faktor [12, 64]. Az N3 centrum esetében a DW faktor 0,03 körül, a HR faktor 3-3,5 között mozog, ami viszonylag erős elektron-fonon csatolásról árulkodik.

Az elektron-fonon csatolás fizikai háttere egy színcentrum optikai átmenete esetében az elektronpályák torzulása az optikai átmenetben résztvevő rezgési módusok miatt. A fononasszisztált lumineszcencia $\left(I_{P H}\right)$ intenzitása a gyémántban általában nagyobb, mint a fononkölcsönhatás nélküli $\left(I_{Z P L}\right)$, különösen igaz ez az ún. „lágy” centrumoknál, amilyenek pl. a nitrogént és szénvakanciát tartalmazó centrumok. Ez azt jelenti, hogy a legtöbb esetben a centrum teljes emissziós intenzitását a fonon oldalsáv határozza meg. A fonon oldalsáv jellemzően a lokális és kvázi-lokális rezgésekkel 
$\left(\hbar \omega_{i}\right)$, valamint a rövid hullámhosszú akusztikus fononokkal való kölcsönhatás eredménye. A lokális és kvázi-lokális rezgésekkel való kölcsönhatást a hibahely szerkezete határozza meg és ennek a kölcsönhatásnak az intenzitására úgy tekinthetünk, mint az adott centrum egyik karakterisztikus jellemzőjére, de nem olyan értelemben, hogy az a (a centrumra jellemző lineáris csatolási koefficiens) egy konstans érték, amellyel az adott centrumot egyértelműen beazonosíthatjuk, elsősorban csak következtethetünk annak természetére. Mivel az elektron-fonon csatolás viszonylag érzékeny a színcentrum környezetére, ezért változhat annak függvényében, hogy a vizsgált minta mennyi szerkezeti hibát tartalmaz.

Matematikailag az elektron-fonon csatolás egyszerü esetben a következő módon írható le. Ha egyetlen rezgési módust tételezünk fel a rendszerünkben, akkor a rendszer teljes energiája az elektronátmenetmenetek energiájának és a rezgési energiának az összege lesz. Ebben az esetben a gerjesztett állapot energiája $V_{e}$ a következő módon írható fel:

$$
V_{e}=E_{e}+\frac{1}{2} m \varpi^{2} Q^{2},
$$

ahol $E_{e}$ az elektron átmenet energiája, $\varpi$ a rezgési módus frekvenciája, míg $m$ a rezgési módushoz társított tömeg, $Q$ pedig az atomok elmozdulása a nyugalmi helyzethez képest. Ha elektron-fonon csatolás lép fel, akkor az előbbi kifejezést a következő módon kell megváltoztatni:

$$
V_{e}=E_{e}+\frac{1}{2} m \varpi^{2} Q^{2}+a Q+b Q^{2},
$$

ahol $a Q$ a lineáris elektron-fonon csatolást jelenti, míg $b Q^{2}$ a kvadratikust. Itt a lineáris kifejezés figyelembe veszi azt a tényt, hogy a rezgés nem ugyanabban a nyugalmi pontban jelentkezik a gerjesztett és az alapállapotok esetében. Az erős lineáris elektron-fonon csatolás a rezgési parabolák eltolódását eredményezi mind az alap, mind pedig a gerjesztett állapotokban, de nem befolyásolja a rezgési nívók közötti távolságot. A gyenge elektron-fonon csatolás esetében a rezgések ugyanazon nyugalmi pont körül alakulnak ki. Másrészről, a kvadratikus kifejezés figyelembe veszi a rezgési frekvencia változását a gerjesztett állapotban, amely a kötéstávolság változásának az eredménye. Általában több rezgési módust kell figyelembe venni, így az előbbi kifejezés a következő alakban írható fel:

$$
V_{e}=E_{e}+\frac{1}{2} \sum_{i} m_{i} \omega_{i}^{2} Q_{i}^{2}+\sum_{i} a_{i} Q_{i}+\sum_{i j} b_{i j} Q_{i} Q_{j},
$$

ahol a szumma jel a különböző módusok összegzését jelenti. A kvadratikus kölcsönhatás esetében a $b_{i i}$ átlós elemek megváltoztatják a $i$-edik módus frekvenciáját, hasonlóan az egymódusú modellnél tapasztaltakhoz. Továbbá, az átlón kívül eső $b_{i j}$ elemek összekeverik a különböző rezgési módusokat. A kvadratikus kölcsönhatás az oka, hogy az abszorpció és az emisszió nem tükörszimmetrikus a 
zérusfonon vonalhoz viszonyítva, valamint a kvadratikus tag felelős a hőmérsékletváltozás által okozott ZPL eltolódásért és kiszélesedésért [63, 6].

A tömbi gyémántban vizsgált $N 3$ centrumot illetően a gerjesztési és az emissziós spektrum szinte teljesen tükörszimmetrikus (lásd a 3.7. ábrán), csak nagyon kis eltérés tapasztalható, ami azt mutatja, hogy az optikai átmenetek során a rezgési módusokkal való kölcsönhatást alapvetően a lineáris elektron-fonon csatolás dominálja. Davies és munkatársai részletesen vizsgálták az N3 centrum emissziós spektrumának rezgési oldalsávját és megadták az egyfonon állapotsürüségi spektrumot két csúcspozícióval 90 meV-nál és 165 meV-nál. Feltételezve, hogy csak lineáris elektron-fonon csatolás van jelen az adott centrumnál az egyes módusok teljesen függetlenek lesznek és az $n$ fononos átmenet valószínűsége az $(n-1)$ és az egyfononos kölcsönhatás spektrumainak konvolúciójával adható meg [62]. Ezzel a modellel, és az általuk szabadon változtatott fonon állapotsürüségi spektrummal viszonylag jól reprodukálható számos optikai centrum, így az N3 hibahely tömbi gyémántkristályban, kísérletileg meghatározott rezgési oldalsávjának finomszerkezete is. Nanogyémánt szerkezetekben azonban az állapotsürüség változhat a szerkezeti sajátosságok miatt, illetve színcentrum-együttesek vizsgálata során, az egyes centrumok esetlegesen eltérő lokális környezetei miatt a centrumokhoz tartozó rezgési szerkezetek átlapolnak egymással, így beazonosíthatatlanná téve a karakterisztikus fonon oldalsáv struktúráit.

\subsection{A szilícium-vakancia ( $\mathrm{SiV}$ ) optikai centrum gyémántban}

A nitrogén szennyezéshez köthető optikai centrumokhoz (amilyen pl. az N3 centrum) viszonyítva a szilícium-vakancia ( $\mathrm{SiV}$ ) hibahely viszonylag „fiatal” színcentrumnak számít a gyémántban intenzíven kutatott optikailag aktív ponthibák között. Ellentétben az említett nitrogénhez köthető centrumokkal, melyek kutatása több mint fél évszázados múltra tekint vissza, a $S i V$ centrum vizsgálata „csak” a 80-as években kezdődött [73]. Ennek legfőbb oka, hogy a szilícium szennyezéshez köthető centrum elsősorban az MW CVD módszerrel előállított gyémántkristályokra jellemző [65-68].

Az irodalomban a $S i V$ centrum kétféle elektromosan töltött állapotát különböztetik meg: A $S i V^{-}$ centrumot, amelynek 1,68 eV-nál (738 nm) van a zérusfonon vonala és a $\mathrm{Si} V^{0}$ centrumot, amely 1,31 eV-nál $(946 \mathrm{~nm})$ emittál. Jelen dolgozatban csak az 1,68 eV fotonenergia körül emittáló, szilíciumhoz köthetö hibahellyel foglalkozom, melyre a továbbiakban csak SiV centrumként hivatkozom.

Az 1,68 eV-nál levő emissziós sávot először 1980-ban detektálták epitaxiálisan növesztett MW CVD rétegekben, majd egy évvel később a sávot szilícium szennyezőhöz rendelték, mivel a 25 különböző típusú ionnal implantált gyémántkristályok közül, csak azoknál volt megfigyelhető, amelyeket szilíciummal implantáltak [65]. 
A CVD leválasztási technológiának fütőszállal kombinált módszerével készített gyémánt rétegekben is sikerült detektálni a $S i V$ centrum emissziós vonalát, mégpedig olyan polikristályos gyémántrétegekben, amelyeket szilícium hordozóra választottak le. Először az 1,675 eV-nál jelentkező emissziós sávot a GRl (a GR hibahely a „general radiation” rövidítése, mivel a centrum általában minden gyémántkristályban kialakul valamilyen részecskével történő besugárzás hatására) centrumhoz rendelték, de a további kísérletek kimutatták, hogy az említett módszerrel szilícium hordozón kialakított gyémántrétegekben az 1,68 eV körüli emissziós sávot a $S i V$ színcentrum jelenléte okozza [69, 70]. A különböző CVD módszerek mellett, SiV centrumot tartalmazó gyémánt kristályokat állítottak elő HPHT módszerrel is szilíciummal szennyezett szén-fém olvadékokból [71].

Szemben a mesterségesen kialakított kristályokkal, amelyekben a $\operatorname{SiV}$ centrumok létrejöttét és gyakori előfordulását megfigyelték, a természetes gyémántban csak nemrégiben igazolták ezen hibahely jelenlétét [72], ami természetesen annak a következménye, hogy a gyémántkristály természetes növekedése és a különböző CVD módszerrel történő mesterséges előállítása között eltérések vannak. Azonban ez egyúttal a mesterséges előállítási módszer alkalmazási potenciáljára is rámutat, ugyanis olyan egyedi tulajdonságokkal rendelkező színcentrumok is előállíthatóak, melyek ritkán, vagy egyáltalán nem keletkeznek a természetes növekedés során.

\subsubsection{A $\mathrm{SiV}$ centrum atomi szerkezete}

Az 1,68 eV-nál emittáló szilícium-vakancia centrum egyike azon kevés optikailag aktív hibahelynek a gyémántban, melynél a zérusfonon vonal pozíciója nem teszi lehetővé a hozzá tartozó hibahelyszerkezet teljesen egyértelmű beazonosítását. Valószínűleg ez a legfőbb oka annak, hogy az említett emissziós sávot sokáig a GRl centrumnak tulajdonították. A SiV centrum emissziójának részletes vizsgálata ma már lehetővé teszi a két centrum megkülönböztetését elsősorban a $\mathrm{SiV}$ emissziójának egyedi jellemzői miatt. Általánosan elfogadottnak tekinthető, hogy míg a SiV centrum ZPL-jének pozíciója 1,68 eV-nál (738 nm), addig a GRl centrumé 1,673 eV-nál (741nm) található.

Az első közvetlen utalást arra, hogy az 1,68 eV-os átmenet nagy valószínüséggel szilíciumot tartalmazó hibahelyhez köthető a Vavilov és csoportja által végzett kísérletsorozatban találjuk, mely során a gyémántkristály szilíciummal implantált részein 1,684 eV-nál jelentkező emissziós sávot detektáltak katódlumineszcenciával végzett vizsgálatok során [65].

A SiV centrum szerkezetének megismerése érdekében tett következő nagy lépés a $200 \mathrm{keV}$ ionenergiájú ${ }^{28} \mathrm{Si}$-al implantált, valamint $2 \mathrm{MeV}$ elektron-besugárzásnak alávetett, kis nitrogéntartalmú CVD rétegek tanulmányozása volt [74]. Az emissziós spektrumokból azt a következtetést vonták le a szerzők, hogy az 1,68 eV-nál jelentkező emissziós sáv szilíciumot és szénvakanciát tartalmaz. Továbbá, először tettek javaslatot a Si atom pozíciójára a gyémánt kristályrácsban, mely szerint a 
szilícium intersticiális helyet foglal el a szomszédos szénvakancia mellett [74, 75]. Ezt követően, az emissziós és gerjesztési spektrum részletes tanulmányozása során a fonon oldalsáv egyes keskeny, és viszonylag intenzív csúcsait a lokális rezgési módusokkal való kölcsönhatáshoz rendelték, amely szintén alátámasztja a $\mathrm{SiV}$ centrum $\mathrm{D}_{3 \mathrm{~d}}$ Szimmetriacsoporthoz való tartozását [76-78].

Alacsony hőmérsékleten és nagy feloldóképességgel rendelkező fluoreszcens mikroszkópon végzett vizsgálatok során a $S i V$ centrum zérusfonon vonala 4 különböző intenzitású emissziós sávra bontható $[79,80]$. Ezen kísérleti eredményekből a szerzők azt a következtetést vonták le, hogy a $S i V$ centrum alap és gerjesztett állapota is felhasad. A későbbiekben végzett mérések során sikerült a centrum zérusfonon vonalának további 12 komponensre történő bontása. Az egyes komponensek intenzitásarányából és a pozícióbeli energiakülönbségekből sikerült beazonosítani egy négy sávból álló szerkezetet, amely háromszor ismétlődik a mért spektrumban. Az intenzitások aránya pedig megegyezik a szilícium izotópok természetes előfordulási arányával. Emellett meghatározták, hogy az alapállapotok felhasadása $0,2 \mathrm{meV}$, míg a gerjesztett állapotok felhasadása 1,07 meV [80].

(a)

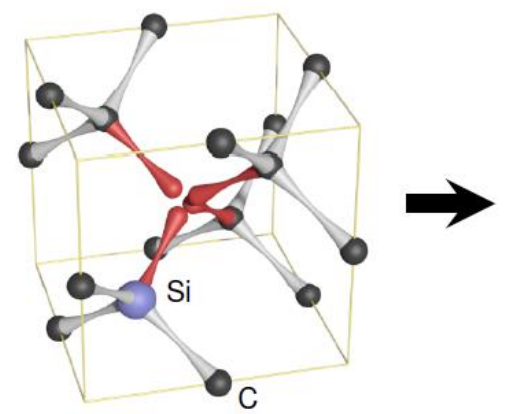

(b)

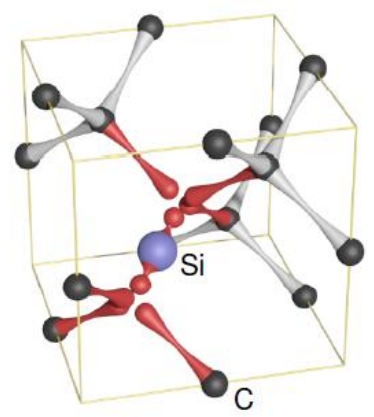

3.8. ábra: A (a) szilícium atom (lila) beépülése a gyémánt kristályrácsba (szürke szénatomok) szubsztitúciós helyre történik, miközben mellette szénvakancia alakul ki. A (b) beépült szilícium atom nagy mérete miatt nem illeszkedik jól a kristályrácsba, ezért egy energetikailag kedvezőbb pozíciót vesz fel a szénvakancia irányába történö relaxációs folyamat során, mely egy úgynevezett osztott vakancia hibahelyszerkezet kialakulását eredményezi [78].

A fentiekben részletezett kísérleti eredményekre alapozva ab initio klaszter módszerrel végzett számolásokkal arra a következtetésre jutottak, hogy a szilícium-vakancia szerkezet esetében a szilícium, a vakancia irányába történő relaxációs folyamat révén, intersticiális pozícióba kerül, egyenlő távolságra a két szomszédos szénvakanciától. Ennek révén egy úgynevezett osztott vakancia (splitvacancy) szerkezet alakul ki, amely energetikailag sokkal kedvezőbb (3.8. ábra). A kialakulási folyamat és a felállított szerkezeti modell jól magyarázta a kísérletileg tapasztalt zérusfonon vonal felhasadását alacsony hőmérsékleten, valamint ismételten megerősítette a már korábban is feltételezett $\mathrm{D}_{3 \mathrm{~d}}$ szimmetriát $[81,78]$. 
A $S i V$ centrum szimmetriájának részletesebb tanulmányozása során, mely polarizációs vizsgálatokkal történt szilícium-vakancia színcentrum-együtteseket tartalmazó CVD rétegeken, azt a következtetést vonták le, hogy a centrum <110> tengely irányú [82], azonban az egy tengely irányú feszültségmérések alkalmazásával kapott eredményekből az $<100>$ irányra következtettek [83]. A legutóbbi vizsgálatok során, a kitüntetett irányban növesztett nanogyémánt kristályokon végzett mérésekből arra a következtetésre jutottak, hogy a centrum $<111>$ tengely irányú, mely a centrum $\mathrm{D}_{3 \mathrm{~d}}$ szimmetriájára utal $[69,78]$.

\subsection{2. $\mathrm{SiV}$ centrumok kialakítása gyémántban}

Hasonlóan a gyémántban vizsgált többi színcentrumhoz, a szilícium-vakancia centrum is három alapvető módon kerülhet kialakításra a különböző gyémánt szerkezetekben. Az egyik ilyen folyamat a gyémánt természetes úton végbemenő kialakulása a föld mélyén, átlagosan 200 km-es mélységben, nagy nyomáson (7-8 GPa) és magas hőmérsékleten (1670-1870 K) [2].

Az ionimplantáció egy másik, általánosan alkalmazott módszer színcentrumok utólagos kialakítására gyémántban, melyet sikeresen alkalmaztak a $\operatorname{SiV}$ centrumok esetében is [80, 84, 35]. Jellemzően az utólagos implantálással kialakított színcentrumok, emissziós tulajdonságaikat tekintve, hátrányban vannak a természetes, vagy akár CVD, esetleg más mesterséges előállítási módszer során in situ módon kialakított idegen szennyezőkhöz köthető hibahelyekkel szemben. Ennek elsősorban az az oka, hogy az alkalmazott nagy ionenergiák roncsolják a kristályrács szerkezetét, valamint az ionok fékeződésének következtében nagyszámú rácshiba, esetleg más típusú hibahely keletkezik a centrum közvetlen környezetében. Az ionimplantálással kialakított SiV centrumok esetében elmondható, hogy az emissziós intenzitás jelentősen kisebb, továbbá a számos alkalmazás szempontjából előnyös egyfoton emisszió aránya sem éri el a CVD módszerrel készült mintákban tapasztaltakat. Nem beszélve arról, hogy a jellemzően keskeny emissziós sávval rendelkező SiV centrum ZPL-jének kiszélesedése figyelhető meg az egyes implantált mintákban. A módszer előnye viszont, hogy általa célzottan, előre pontosan meghatározott területen tudunk $S i V$ centrumot kialakítani.

A $S i V$ centrum kialakításának optimális módja a CVD rétegnövesztés során a minta szilícium atommal való szennyezése valamilyen Si forrás felhasználásával [83, 85]. A Si forrás lehet maga a hordozó, a reaktorkamra fala, vagy egyéb, szilíciumot tartalmazó anyag a plazmatérben, esetleg külső forrásból származó, szilíciumot tartalmazó gáz. A legegyszerübb eljárás, amikor Si kristályt használnak szilícium forrásként, akár hordozó formában is, a centrumot tartalmazó gyémántkristály előállítására. A folyamat lényege, hogy szilícium kristálydarabkát helyeznek el a hordozóra a plazmatérben. A plazmában lévő aktív gyökök, ionok marják az elhelyezett kristályt, így Si atomok/ionok kerülnek a plazmatérbe, ahol a gyémántleválasztás történik. A Si atomok kölcsönhatnak a növekvő 
kristályszerkezettel és beépülnek a gyémántrácsba. A leírt módszer lehetővé teszi a gyémánt kristályban $3 \times 10^{19} \mathrm{~cm}^{-3}$ centrumsürüség kialakítását [86]. Az ezzel a módszerrel előállított mintákban levő SiV centrumok kiváló emissziós tulajdonságokkal rendelkeznek, mind az emissziós intenzitás, mind pedig a vonalkiszélesedés tekintetében. A CVD módszerrel előállított egyedi gyémántkristályban 4 K hőmérsékleten a $S i V$ centrum ZPL-jének 0,8 nm-es kiszélesedését mérték, ami az eddig detektált egyik legkeskenyebb idegen szennyezőhöz köthető emissziós sáv a gyémántban [87, 6]. A jelenleg elfogadott mechanizmus szerint a Si atom először szubsztitúciós helyre épül be, majd mivel a Si atom viszonylag nagyméretű a szénatomhoz képest, ezért a következő atomi rétegben a beépült Si atommal közvetlenül szomszédos rácshelyen szénvakancia keletkezik a feszültségek kompenzálására. Ezután a következő növekvő atomi réteg elfedi a keletkezett hibahely szerkezetet, mivel azonban a Si atom szempontjából energetikailag előnyösebb az osztott vakancia szerkezetbe való relaxáció, az atom egy köztes helyet foglal el, egyenlő távolságra a két rácsvakanciától.

\subsubsection{A $S i V$ centrum lumineszcencia tulajdonságai}

A gyémántban kialakított szilícium-vakancia optikai centrum egyfoton emitter. Az emissziós intenzitás több mint $70 \%$-a a zérusfonon vonalba koncentrálódik, tehát gyenge az elektron-fonon csatolás, és így a rezgési oldalsáv intenzitása is [75,6]. A zérusfonon vonal pozíciója $738 \mathrm{~nm}$, ami az élő szövet legnagyobb áteresztőképességgel rendelkező hullámhossztartományába esik. Az emisszió még szobahőmérsékleten is nagyon stabil, vagyis villódzás és kifehéredés mentes. A SiV színcentrum extra emissziós tulajdonságainak köszönhetően áttörést hozhat számos újtípusú alkalmazás területén, amelyek között a kvantuminformatika, a kvantumkriptográfia, az új típusú biojelzők és a nanoméretü fotonikai eszközök kiemelt helyet foglalnak el. Az említett területek mindegyike a SiV centrum azon tulajdonságait kívánja hasznosítani, amelyek miatt a centrum kiemelt helyet foglal el a gyémántban kialakított optikailag aktív hibahelyek kutatási területén.

Annak érdekében, hogy ezen tulajdonságokat megfelelően tudjuk változtatni, illetve optimalizálni az adott alkalmazás számára, részletesen fel kell tárnunk azokat a tényezőket, illetve folyamatokat, melyek hatással vannak a SiV optikai centrum emissziós tulajdonságaira. A következő pontokban a SiV centrum lumineszcenciájával kapcsolatos eddigi eredményeket foglalom össze.

\subsubsection{A $S i V$ centrum emissziós spektruma}

A $S i V$ centrum egyik legjellemzőbb tulajdonsága a gyenge elektron-fonon csatolás, ami azt jelenti, hogy az 1,68 eV-nál (738 nm) jelentkező keskeny emissziós sáv (ZPL) intenzitása mellett a hozzá tartozó fonon oldalsáv intenzitása nagyon kicsi. A centrumra jellemző Huang-Rhys faktor 
0,24 $\pm 0,02$, ami alkalmazás szempontjából gyenge elektron-fonon kölcsönhatást jelent [75]. A centrum gyenge rezgési oldalsávjában a ZPL-től a 40, 64, 90, 125, 155 meV energiára lévő sávok a ZPL elektron-fonon csatolás keltette replikái, melyek közül a legintenzívebb a 64 meV-os rezgési sáv (lásd a 3.9. ábrán) [1, 68, 88]. Míg a 40, 64 és 90 meV körül található módusok lokális rezgésekhez tartoznak, addig a $125 \mathrm{meV}$ a gyémánt longitudinális akusztikus (LA), a $155 \mathrm{meV}$ pedig a gyémánt transzverzális akusztikus (TA) fonon módusa. A zérusfonon vonal intenzitása változó az egyes mintákban. Általában a jó minőségű CVD mintákban intenzív, míg jóval kisebb az emissziós intenzitás a sok hibahelyet tartalmazó defektusos vékonyrétegekben. Esetenként utóbbi mintákban nem is mérhető [89, 6].

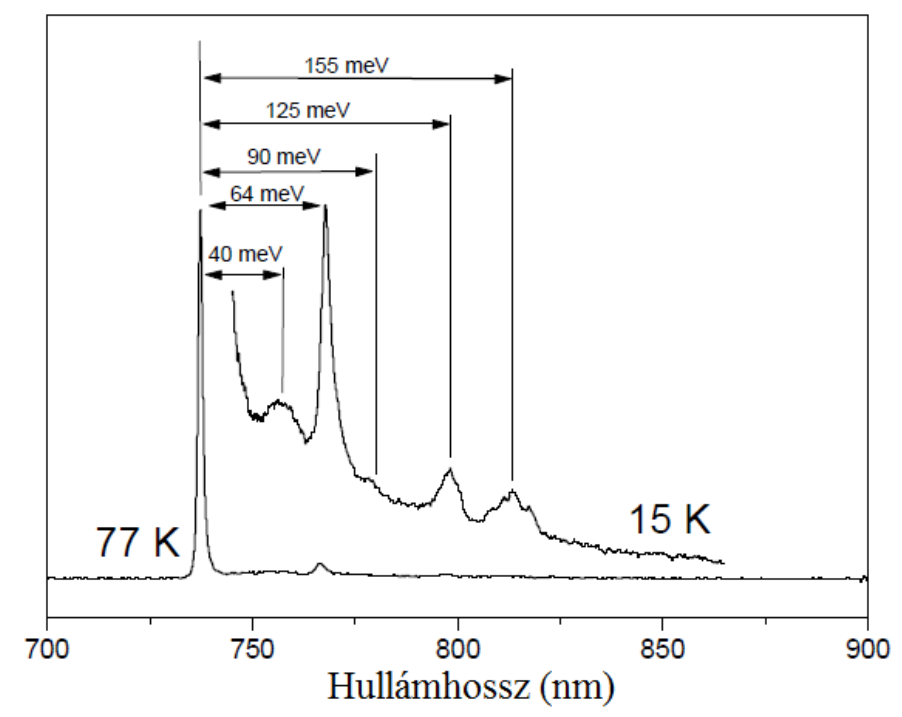

3.9. ábra: A SiV centrum 514,5 nm ( 2,41 eV) lézerhullámhosszal gerjesztett lumineszcencia spektruma $77 \mathrm{~K}$-en mérve, valamint a hozzá kapcsolódó, $15 \mathrm{~K}$-en mért fonon oldalsáv szerkezete felnagyitva [1].

A $S i V$ centrum zérusfonon vonala szobahőmérsékleten egyetlen emissziós sávból áll 1,68 eVnál, melynek nincs finomszerkezete. Alacsony hőmérsékleten viszont láthatóvá válik a ZPL finomszerkezete, amely így 4 összetevő sávra bomlik fel az alap és gerjesztett állapotok spin-pálya kölcsönhatásának felhasadása miatt. Az izotóp effektus megsokszorozza a finomszerkezetet [80].

A $S i V$ centrum zérusfonon vonalának félértékszélessége szobahőmérsékleten 2 és $35 \mathrm{meV}$ között változik a CVD módszerrel leválasztott rétegekben. Az eddigi legkeskenyebb emissziós sáv, melyet egyedi gyémánt nanoszemcsén mértek, feltételezhetően egyetlen $\mathrm{SiV}$ centrumon, alacsony hömérsékleten $0,8 \mathrm{~nm}(\sim 2 \mathrm{meV})[1,90,87]$.

A zérusfonon vonal aszimmetrikus vonalalakját a kisenergiájú oldalon, valamint a ZPL pozíciójának viszonylag nagy szórását több alkalommal is megfigyelték. A csúcspozíció szórása az egyes szerzők által vizsgált minták esetében néhány tized meV-tól, egészen 10 meV-ig terjed [90]. A legnagyobb szórást a CVD módszerrel előállított egyedi SiV centrumok vizsgálata során tapasztalták. 
A csúcspozíció szórására a leggyakoribb magyarázat a lokális belső feszültség változása, amit feltételeznek csupán, tényleges mérésekkel nem támasztották alá.

Az aszimmetrikus vonalalak értelmezésére jelenleg nincs általánosan elfogadott magyarázat. Javasolták a színcentrum-együttest alkotó egyedi centrumok okozta inhomogén vonalkiszélesedést [6], ugyanakkor közel azonos energiánál emittáló másik centrum is felmerült magyarázatként [91]. Annak ellenére, hogy az 1,673 eV-nál emittáló GRl centrum kézenfekvő magyarázatként szolgálna az aszimmetrikus kiszélesedésre, a mért spektrum dekompozíciójából kapott eredmények miatt ez a feltételezés nem került megerősítésre mindeddig [91].

\subsubsection{A $S i V$ centrum emissziójának gerjesztési spektruma}

Ahogy az optikailag aktív centrumok mindegyikénél, így a $\mathrm{SiV}$ centrum esetében is ahhoz, hogy megfelelő legyen az emissziós intenzitás, valamint, hogy a lehető legkisebbre redukáljuk az esetleges háttérremissziót, vagy más centrum emissziójának az intenzitását, érdemes megvizsgálni az adott centrum gerjesztési spektrumát. A gerjesztési spektrum mérésével az N3 centrumnál már részletesen foglalkoztam.

Az elvégzett vizsgálatok azt mutatták, hogy a SiV centrum a teljes látható hullámhossztartományban gerjeszthető, de eltérő hatékonysággal [1, 53, 68]. Ebből a szempontból a gerjesztési spektrum három részre tagolható. Egy viszonylag széles, 1,75 eV-tól 2,55 eV-ig terjedő fotonenergia-tartományra, amelyen belül a centrum jól gerjeszthető és amely a gerjesztési spektrumban kísérletileg is gyakran megfigyelhető [89]. Ezeknél a fotonenergiáknál az emisszió viszonylag jó hatékonysággal gerjeszthető. A gerjesztési spektrumban egy rezonáns jelenséget figyeltek meg 1,98 eV körül, amelyet a centrum második gerjesztett állapotának tulajdonítottak. A második gerjesztett állapot 0,3 eV-ra helyezkedik el az első (1,68 eV) gerjesztett állapot fölött [92].

A $S i V$ centrum emissziója azonban a leghatékonyabban az abszorpciós él fölötti energiákkal (>5,5 eV), valamint magának a centrumnak az abszorpciós sávjában, tehát rezonánsan gerjeszthető [1, 6]. A lumineszcencia gerjesztésének hatékonysága mellett azonban megfontolandó a centrum ionizálásának a lehetősége, amely megfigyelhető a nitrogén-vakancia centrum esetében. Az $N V$ centrumnál 2,33 eV (532 nm) lézerfénnyel történő megvilágítás hatására változtatható a töltési állapot $[26,93]$. Ez a jelenség csökkentheti az emissziós intenzitást, mivel az ionizáció hatására a centrum egy másik hullámhossznál fog emittálni. A töltési állapot változása lehet a magyarázata a színcentrumoknál megfigyelt fluoreszcencia villódzásnak is [94, 95]. Ilyen villódzó jelenséget a $S i V$ centrum esetében $450 \mathrm{~nm}$, vagy ennél kisebb hullámhosszú fénnyel történő megvilágítás hatására figyeltek meg [89]. Ezért célszerű olyan gerjesztő fotonenergiát választani, amely a lehető legkisebb, így nem okozhatja a centrum töltési állapotának a megváltozását fotoionizáció útján. A 3.10. ábrán a gerjesztés és az azt 
követő relaxáció sematikus ábrázolása látható, feltüntetve a $S i V$ centrumhoz tartozó alap- és gerjesztett állapotokat a gyémánt tilos sávjában. A SiV centrum alapállapota $\sim 2,05 \mathrm{eV}$ energiatávolságra található a gyémánt vezetési sávja alatt.

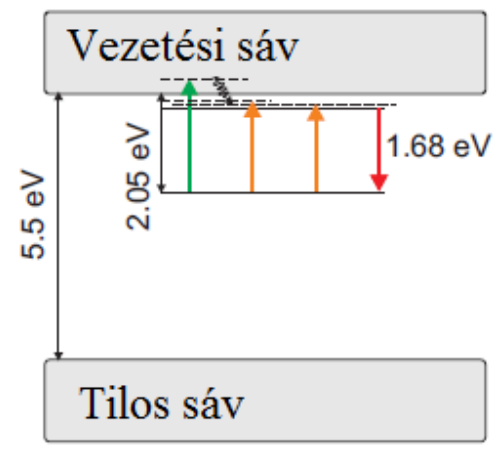

3.10. ábra: A SiV centrum elektronnivóinak ábrázolása a gyémánt tilos sávján belül, valamint a különbözö gerjesztő energiák használata során lezajló folyamatok sematikus ábrázolása. A fölfelé mutató függöleges nyilak a gerjesztést, míg a lefelé mutatók az emissziót ábrázolják. A hullámos vonal a fotogerjesztett töltéshordozó termalizációját és a nemsugárzó átmenettel történö csapdázódását mutatja [6].

\subsubsection{A $S i V$ centrum zérusfonon vonalának spektrális jellemzői}

A legtöbb gyakorlati alkalmazás feltétele a keskeny és intenzív emissziós sáv, illetve hogy a ZPL-be koncentrálódjon a színcentrum emissziójának legnagyobb hányada. Ezek alapján a SiV centrum nagyon ígéretes, extra emissziós tulajdonságokkal rendelkező, keskeny sávban emittáló hibahely, ahogy azt az alábbiakban látni fogjuk.

$\mathrm{Az}$ irodalomban a legtöbb zérusfonon vonalra vonatkozó eredményt a $\mathrm{SiV}$ színcentrumegyüttesekre (ensembles), vagyis nem egyetlen SiV centrumra kapták. Ezen eredményeknél jól megfigyelhető a centrum ZPL-jének eltérő mértékủ kiszélesedése a különböző minták esetében. Míg egyes szerzők a polikristályos gyémántban vizsgált SiV centrumok $15 \mathrm{meV}$-os (6,5 nm) vonalkiszélesedéséröl számolnak be, addig mások, ugyanezen típusú anyagban, 13,6 meV (6nm) mértékü vonalkiszélesedést figyeltek meg [77, 68]. Nemrégiben pedig a polikristályos gyémántra vonatkozóan $16 \mathrm{meV}$, az ultrananokristályosban 18 meV-nak megfelelö vonalkiszélesedésröl írtak [96]. A nagy belső feszültséggel rendelkező polikristályos gyémántban a $\mathrm{SiV}$ centrum ZPL-je felhasadhat, illetve kiszélesedhet a 733-745 nm (1,6915-1,6642 eV) hullámhossztartományban [90, 1]. Azonban sokan úgy gondolják, hogy a $\mathrm{SiV}$ centrum vonalkiszélesedése elég keskeny lehet az egyfoton emissziós alkalmazások megvalósításához [97].

Talán még a makroszkópikus mintákban tapasztaltaknál is látványosabb az eltérés az egyes egyedi centrumok ZPL tulajdonságait összehasonlítva. Az egyedi centrumok vonalkiszélesedése 9-12 
meV között változik, de található olyan irodalmi eredmény is mely $2 \mathrm{meV}$ félértékszélességről számol be. Az egyedi centrumok esetében, míg az egyes szerzők a 736,8 nm-nél található emissziós sávot már nem a SiV-hez kötik, addig mások az ennél jóval nagyobb csúcspozícióbeli eltolódást is az inhomogén kiszélesedéssel magyarázzák és a szilícium-vakancia hibahelyhez rendelik. Mivel az esetek szinte mindegyikében a ZPL kékeltolódásáról számolnak be, érdekes lehet megvizsgálni ezen jelenség hátterét.

\subsubsection{Elektron-fonon csatolás a $\mathrm{SiV}$ centrumnál}

A rezgési oldalsáv az emisszió során legnagyobb valószínűséggel akkor jelentkezik, ha az átmenet a gerjesztett állapot rezgési alapállapotából $\left(n^{\prime}=0\right)$ az alapállapot egyik magasabb szinten elhelyezkedő rezgési nívójára ( $\mathrm{n}>0$ ) történik (3.11. ábra). Ebből kifolyólag az emisszióban megjelenő sávok vöröseltolódást szenvednek a ZPL-hez képest. Ennek megfelelően az eltolódás mértéke megadja az adott fononmódus energiáját, ha $\mathrm{n}=1$ (egyfonon oldalsáv). A magasabb fononmódusok esetében $(\mathrm{n}>1)$ az energia az egyfonon módus energiájának többszöröse. Az emissziós spektrum rezgési oldalsávja, hasonlóan a ZPL-hez, az adott centrum karakterisztikus tulajdonsága és együttesen hozzájárulnak az adott emissziós centrum beazonosításához.

A SiV centrum rezgési oldalsávjának intenzitása a ZPL intenzitásához képest gyenge, ami gyenge lineáris elektron-fonon csatolást feltételez. Ezen tulajdonság számos alkalmazás szempontjából alapvető. A lineáris elektron-fonon csatolás jellemezhető a DW és a HR faktorokkal egyaránt, melyekről már részletesen szó volt az N3 centrum kapcsán. A SiV centrumra vonatkozó irodalmi eredményeket tekintve, a különböző mintákban és különböző gerjesztésekkel meghatározott HR faktorok némileg eltérőek. Míg szobahőmérsékleten 457 nm-es $(2,713 \mathrm{eV})$ gerjesztésnél HR=0,1, addig $9 \mathrm{~K}$ hőmérsékleten, $515 \mathrm{~nm}$-es $(2,407 \mathrm{eV})$ gerjesztés mellett $\mathrm{HR}=0,08$-ra csökken [92, 68]. Ezzel szemben a $\mathrm{SiV}$ abszorpciós spektrumát vizsgálva $\mathrm{HR}=0,24$ értéket találunk szobahőmérsékleten [35]. A szórás magyarázata valószínűleg, hogy a különböző vizsgálatoknál eltérő spektrális tartományban vizsgálták a centrumhoz tartozó emissziós/abszorpciós spektrum tulajdonságait, aminek ismeretében kijelenthető, hogy a $S i V$ centrum Huang-Rhys faktorának tényleges értéke nem teljesen egyértelmü.

Feltételezve, hogy $\mathrm{HR}=0,24$ az egyfonon oldalsáv ZPL-hez viszonyított intenzitása 24\%, míg a kétfononé csak 2,8\%, ezért aztán a ZPL dominálja a spektrumot. A SiV centrum esetében nem is várható intenzív fonon oldalsáv, amely a kétfononos folyamathoz köthető, ugyanis a nehéz atomot tartalmazó színcentrumok esetében már a lineáris elektron-fonon kölcsönhatás jellemzően gyenge [1, 6]. Szemben a nitrogén-vakancia centrummal, amelynek Huang-Rhys faktora $H R=3,73$, így nagyon intenzív fonon oldalsáv emisszióval rendelkezik és a ZPL detektálása szobahőmérsékleten sokszor nem is lehetséges [98]. 
A 3.11. ábrán az elektron-fonon csatolás egy nagyon leegyszerüsített képét láthatjuk, ahol az egyszerüsítés miatt feltételezzük, hogy csak egy rezgési módus csatolódik a színcentrumhoz. A szilárd testekben különböző típusú rezgési módusok okozhatják az oldalsávként jelentkező emissziót:

- rács módusok, amelyek a sértetlen gyémántrács rezgéseihez köthetőek

- lokális, és kvázi-lokális módusok, amelyek hibahely specifikusak és tartalmazzák magának a hibahelynek és a hibahely környezetének a rezgéseit.

(a)

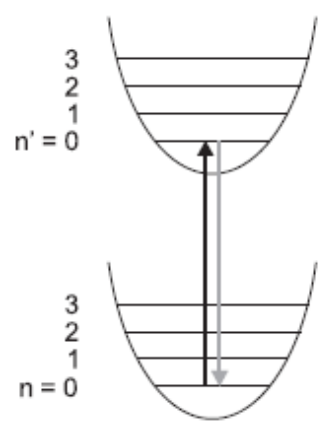

(b)

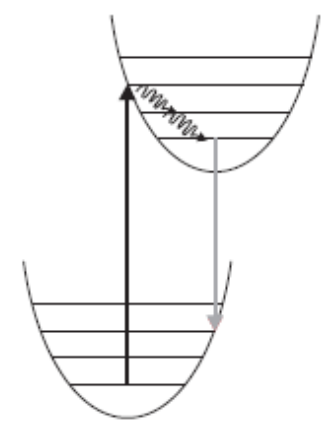

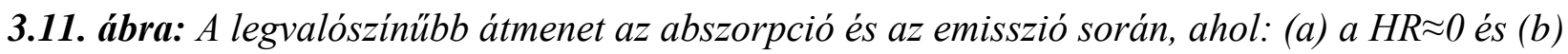

$$
H R=2 .
$$

A rácsrezgésekhez való csatolást a gyémántrács fonon állapotsürüsége határozza meg, amelyet több alkalommal kiszámoltak, és kísérletileg is meghatároztak [1, 99, 100]. A színcentrumnál történő elektronátmenetnél az elektron-fonon csatolás szempontjából elsősorban azokkal a fononokkal kell számolni, melyek hullámvektora a Brillouin zóna magasabb szimmetriájú pontjaiban találhatóak, az ún. kritikus pontokban [1,77]. Ennek két fó oka van. Az egyik, hogy ezeknek a fononoknak a legrövidebb a hullámhossza, ezért a legnagyobb változásokat okozhatják az atomok közötti távolságban, ugyanakkor ezek a hullámhosszak összevethetőek a színcentrum térbeli méreteivel. A másik, hogy a fonon állapotsűrüség ezeknél a pontoknál az ellaposodó fonondiszperziós görbe miatt jelentősen megnő és maximumhelyeket mutat $[100,101]$. Az elektronátmenet elsősorban akkor hat kölcsön az optikai fononokkal, ha a rácsatomok antifázisú mozgása ezeknél a módusoknál jelentős atomok közötti távolságváltozást okoz. Az akusztikus módusok esetében csak a rövid hullámhosszú akusztikus módusok okoznak jelentős atomok közötti távolság változást, ezért intenzív kölcsönhatás jellemzi őket. A gyémánt fonon állapotsürüsége egy keskeny sávból áll 165 meV, illetve egy kevésbé intenzív és viszonylag szélesebb sávból $70 \mathrm{meV}$ körül. Az utóbbi érték alatt pedig drasztikusan csökkenő tendenciával rendelkezik. Ebből következően a 70 meV-nál kisebb és 165 meV-nál nagyobb energiájú módusok a fonon oldalsávban nem a ráccsal való kölcsönhatáshoz köthetőek, azonban a nagyobb energiájú eltolódások származhatnak a többfononos kölcsönhatásokból. A SiV centrum esetében ezek a többfononos kölcsönhatások kevésbé valószínüek, a fonon oldalsáv finomszerkezetét 
jellemzően a lokális fononokkal való kölcsönhatások okozzák. A kisenergiák felé való eltolódás teljesen a lokális módusoknak tulajdonítható.

A kvázi-lokális és lokális módusok főként csak idegen szennyezőatom jelenlétében jelentkeznek. Ha ezen módusok energiája a rács fonon állapotsürüségén belül helyezkedik el, akkor kvázi-lokális módusokról beszélünk. Ha a módus energiája nagyobb 165 meV-nál, vagy kisebb 70 meV-nál lokális módusoknak nevezzük. A rezgési frekvenciáját ezeknek a módusoknak a szennyező atom tömege és az atomok közötti kötési erő határozza meg. Az egyszerüsített modell, mellyel meghatározható a nehéz szennyező atomokat tartalmazó centrumok kvázi-lokális módusának frekvenciája (3.12.) és rezonancia szélessége (3.13.) arra az egyszerüsítésre épül, hogy ezek a szennyezők nem változtatják meg jelentősen az atomok közötti kölcsönhatás erősségét [102]:

$$
\omega_{Q L}=\omega_{D} \sqrt{\frac{M_{C}}{3\left(n M_{I}-M_{C}\right)}} \quad \text { és } \quad \Delta \omega_{Q L}=\frac{\pi}{6} \omega_{D} \frac{M_{C}}{3\left(n M_{I}-M_{C}\right)},
$$

ahol $M_{C}$ és $M_{\mathrm{I}}$ a szénatom és a szennyező atom tömege, míg $n$ a szennyező atomok számát jelöli, melyek részt vesznek a rezgésben. Az $\omega_{D}$ pedig a gyémánt Debye frekvenciája, ami $150 \mathrm{meV}$.

Az irodalomban található számos eredmény azt mutatja, hogy a rezgési oldalsáv, ezáltal a lineáris elektron-fonon kölcsönhatás a $S i V$ centrum környezetétől erősen függ. Egyes eredmények azt mutatják, hogy a ZPL-hez képest 166 meV távolságra található rezgési módus csak bizonyos helyeken jelentkezik a homoepitaxiálisan növesztett CVD rétegeknél [79]. Sok esetben pedig a fonon oldalsáv spektrális feloldása nem is lehetséges [68]. Rezonáns, azaz 737 nm-es gerjesztéssel vizsgálva a SiV centrum emissziójának rezgési oldalsávja jól beazonosíthatóvá válik, amit a szerző a színcentrumegyüttesen belüli egyes egységes csoportok szelektív gerjesztésével magyaráz. Ezek a jól megkülönböztethető szerkezetek nem ismerhetőek fel a spektrumban, amint egy nagyobb centrumegyüttest gerjesztünk, mivel az egyes centrumokra jellemző fononmódusok keverednek és elmosódnak [63]. Ez a megfigyelés is jól tükrözi azt, hogy a centrum környezete lehet eltérö, ami akár egy adott mintán belül is befolyásolja, és esetleg meg is változtatja a centrum spektrális tulajdonságait. 


\section{Célkitúzés}

Annak ellenére, hogy a gyémántban található optikailag aktív hibahelyek vizsgálata már több mint fél évszázados múltra tekint vissza, ezen típusú defektusok csak a nanotechnológia elterjedésével váltak igazán népszerüvé a kutatók körében. E mögött elsősorban azon újszerü alkalmazási lehetőségek, illetve már létező felhasználási területek revolúciója áll, melyek főként a nanooptikát, nanoszenzorikát, kvantuminformatikát és -kriptográfiát, illetve a nanobiológiát és gyógyászatot foglalják magukba.

Sok esetben azonban a nanogyémánt lumineszcencia centrumok kialakításához szükséges technológia, mely lehetővé teszi a tömbi kristályban már ismert és előnyös tulajdonságokkal rendelkező színcentrumok kialakítását, nehezen hozzáférhető, vagy nem teszi lehetővé gazdaságilag is hatékonyan a centrumok kialakítását nagy mennyiségben. Problémát jelenthet az is, hogy sokszor a tömbi gyémántkristálynál alkalmazott módszerek, a szerkezeti sajátosságok miatt nem alkalmazhatóak a nanogyémánt esetében, így új, a nanogyémánt szerkezetekre kihegyezett technológiai eljárások kidolgozása kiemelten fontos. Emellett alapkutatás szempontjából is kiemelt szerepe van az olyan egyedi tulajdonságokkal rendelkező hibahelyek nanogyémánt kristályokban történő utólagos kialakításának és vizsgálatának, melyek korábban csak nagyobb méretü gyémántkristályokban voltak megfigyelhetőek. Ilyen az UV közeli emisszióval és paramágneses tulajdonsággal rendelkező N3 centrum, mely bár a természetes kristályokban az egyik leggyakoribb hibahely, utólagos kialakítása a centrum szerkezetéből adódóan nem egyszerü és nanoméretű kristályokban mindeddig nem sikerült. Másrészről, a már jól bevált technológiákkal kialakított színcentrumok spektrális tulajdonságai, melyek számos alkalmazás szempontjából alapvetően fontos jellemzői az adott hibahelynek, széles tartományban változnak a különböző mintákban. Az egyfoton emitterként alkalmazható, közeli infravörös tartományban emittáló $S i V$ centrum zérusfonon vonalának csúcspozíciója az irodalmi eredmények alapján több 10 nm-t változhat, míg félértékszélessége akár egy nagyságrenddel is eltérhet a különböző mintákban. Ez egyrészt megnehezíti az adott alkalmazási területhez szükséges egységes spektrális tulajdonságokkal rendelkező hibahelyek korlátlan kialakítását, másrészt arra enged következtetni, hogy a szerkezeti tulajdonságok változtatásával a centrum spektrális tulajdonságai az adott alkalmazásra szabhatóak.

Kutatómunkám célkitüzéseit az irodalmi előzmények ismeretében a következőkben tudom összefoglalni:

Kis átlagos szemcseméretü $(<20 \mathrm{~nm})$ nanogyémántban nitrogén szennyezési centrumhoz köthető, komplex hibahely kialakítása olyan technikák alkalmazásával, amelyek kevésbé roncsolják a 
nanoszemcséket és laboratóriumi körülmények között könnyen hozzáférhetőek. A komplex centrum lehetőleg az ultraibolya hullámhosszakhoz közeli tartományban emittáljon.

A komplex lumineszcencia centrum kialakítása céljából a megfelelő hőkezelési eljárások kidolgozása, amelyek egyúttal a roncsolt szerkezet relaxációját is elősegítik. Ezen változások monitorozása Raman-spektroszkópiai vizsgálatokkal. A kialakított komplex lumineszcencia centrum beazonosítása az emisszió zérusfonon vonala és fonon oldalsávja alapján.

SiV centrumok kialakítása különböző preparációs körülmények mellett leválasztott nanogyémánt vékonyrétegekben a rétegnövesztés során MW CVD módszerrel. Az így kialakított $\mathrm{SiV}$ centrumok zérusfonon vonalának spektrális jellemzése lumineszcencia spektroszkópiai vizsgálatokkal. A lumineszcencia vizsgálatokból meghatározott spektrális paramétereknek a tanulmányozása a $\mathrm{SiV}$ centrum lokális környezetét jellemző belső feszültség és a nanogyémánt vékonyréteg textúráját jellemző átlagos szemcseméret függvényében. A belső feszültség meghatározására a gyémánt Ramanszórási sávját analizálom, míg a szemcseméretet a pásztázó elektronmikroszkópiával végzett vizsgálatokból határozom meg. A vizsgálatok célja, hogy felderítsük a zérusfonon vonal spektrális paramétereinek az irodalomban publikált jelentős szórásának fizikai hátterét. 


\section{Kísérleti rész}

Ez a fejezet három fö egységre tagolódik. Az első részben röviden bemutatom az N3 centrum utólagos kialakításához használt nanogyémánt kristályok előállításának folyamatát, illetve ismertetem a mintakészítés egyes lépéseit. Szintén ebben a részben ismertetem a nanogyémánt mátrix-anyagban színcentrumok utólagos kialakításához használt plazma immerziós ionimplantáció (PIII) és fókuszált ionnyalábos besugárzás (FIB) technikákat. Továbbá, itt foglalkozom az implantált minták utólagos hőkezelésével, majd egy közelítő feltételezést alkalmazva a nanogyémánt szemcsékből készült minták átlagos sűrüségére SRIM (Stopping and Range of Ions in Matter) kalkulációkkal meghatározom az implantált ionok mélységeloszlását a mintákban.

A második és harmadik alfejezetben kerül sor a kísérleti munkám során alkalmazott vizsgálati módszerek, így a Raman-spektroszkópia és a fotolumineszcencia spektroszkópia rövid bemutatására. Ennek keretében először a színcentrumok kialakítására szolgáló nanogyémánt mátrix-anyag jellemzésére kerül sor Raman-spektroszkópiával, majd ezt követi a MW CVD módszerrel leválasztott nanogyémánt rétegek morfológiájának bemutatása a SEM felvételek alapján, továbbá az átlagos szemcseméretek meghatározása az előállítási paraméterek függvényében. Végül a fotolumineszcencia vizsgálati módszerrel foglalkozom, amelyet a nanogyémántban kialakított színcentrumok beazonosítására és alkalmazás szempontjából lényeges spektrális paramétereinek jellemzésére használtam.

\subsection{Mintakészítés}

A kutatási célkitüzéseimben szereplö $N 3$ és $S i V$ színcentrumokat nanogyémánt mátrixanyagban alakítottam ki. A kísérleteimben két különböző módon előállított nanogyémánt szerkezetet használtam. Az N3 centrumot robbantásos eljárással előállított nanogyémántban alakítottam ki, míg a SiV centrumot az MW CVD módszerrel előállított nanokristályos vékonyrétegben hoztam létre a rétegnövesztési folyamat során.

A detonációval készült nanogyémántot kereskedelmi forgalomból szereztem be, ezért itt csak röviden ismertetem magát a robbantásos előállítási módszert. Részletesebben foglalkozom viszont a nanogyémánt vékonyrétegek előállításával, amelyek MW CVD módszerrel a saját laboratóriumunkban készültek.

\subsubsection{Nanogyémánt por}

Az N3 színcentrumok kialakítására a kereskedelmi forgalomból beszerezhető, NEOMOND Ltd. (Dél-Korea) által gyártott, elsősorban laboratóriumi felhasználásra készített, jó minőségü, detonációs nanogyémánt kristályokat használtam, melyeknek néhány tulajdonságát a dolgozat végén 
található 12.1. függelékben adom meg. A gyártó cég kiválasztásánál fontos szempont volt, hogy garantálják a nanogyémánt szemcsék megfelelő felületi tisztaságát a nagy fajlagos felület miatt és a gyémánt szemcsék dezintegrációját a megfelelő átlagos szemcseméret biztosítása céljából. E vonatkozásban a cég által rendelkezésre bocsátott adatokat utólagos méréssel ellenőriztem és a fejezetnek a minták minősítésével foglalkozó részében ismertetem az eredményeket. A kereskedelemben kapható nanogyémánt kristályok előállítási folyamatának lépései eltérőek lehetnek és ezek részleteiről általában a gyártó - saját érdekeit védve - kevés információt ad meg.

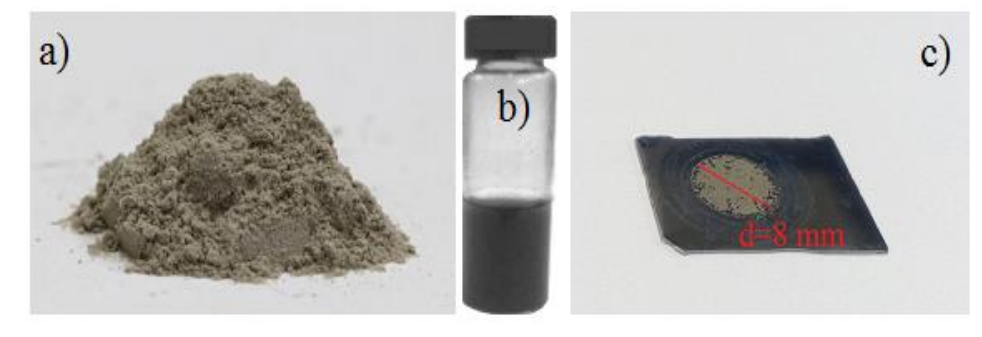

5.1. ábra: A kísérletek során használt (a) nanogyémánt por, (b) a belöle készittett $1.5 \mathrm{mg} / \mathrm{ml}$ sürüségü szuszpenzió és (c) a száradás utáni vékonyréteg.

Robbantásos eljárással nanoméretü gyémántkristályokat először a volt Szovjetunióban állítottak elő az 1960-as években [104]. A módszer lényege, hogy egy zárt fémkamrában trinitrotoluol $\left(\mathrm{C}_{6} \mathrm{H}_{2}\left(\mathrm{NO}_{2}\right)_{3} \mathrm{CH}_{3}\right)$ és hexogén $\left(\mathrm{C}_{3} \mathrm{H}_{6} \mathrm{~N}_{6} \mathrm{O}_{6}\right)$ elegyét robbantják föl $\mathrm{N}_{2}, \mathrm{CO}_{2}$, vagy $\mathrm{H}_{2} \mathrm{O}$ atmoszférában, így maga a robbanóanyag molekulái szolgáltatják a szén forrását, illetve a szükséges energiát az átalakuláshoz [4]. A robbanás terméke, az ún. detonációs korom, mely egyaránt tartalmaz néhány nanométer átmérőjű gyémánt szemcséket és a szén egyéb allotróp módosulatait, valamint más szennyezőanyagokat is. Ezt követően a detonációs kormot egy többlépcsős mosási, tisztítási és centrifugálási folyamatnak vetik alá, melynek végeredménye a felületi szennyezésektöl maximálisan megtisztított nanogyémánt.

A kísérleteimhez nanogyémánt port használtam, melyből szuszpenziót készítettem desztillált víz segítségével (5.1. ábra). A szuszpenzióban a nanogyémánt koncentrációja $1,5 \mathrm{mg} / \mathrm{ml}$ volt. Mivel a néhány nanométer átmérőjű nanogyémánt szemcsékre jellemző tulajdonság, hogy összetapadnak és agglomerátumot alkotnak, ezért a szuszpenziót 3 órás ultrahangos rázatásnak vetettem alá, mely elősegíti az agglomerátumok dezintegrációját és a szemcsék homogén eloszlását a desztillált vízben. A további kísérletek elvégzése, valamint a minták egyszerü kezelhetősége érdekében a fentiekben előállított szuszpenzióból „,vékonyréteget” készítettem szilícium lapkára történő cseppentéssel. Az egyes cseppek Si lapkán való pozícionálása és a nanokristályok egyenletes leülepítése céljából 0,8 cm átmérőjű O-gyürüket használtam, amelyek megakadályozták a szuszpenzió túl nagy felületen történő szétterülését. A leírt módon előkészített mintákat 48-72 órán keresztül szárítottam szobahőmérsékleten. 
A pozícionáló O-gyürűk eltávolítása után a szilícium hordozón kör alakú gyémánt „vékonyréteg” mintákat kaptam, melyeket a későbbiekben részletezett kezeléseknek vetettem alá.

\subsubsection{Implantálás}

Míg az MW CVD módszerrel előállított nanogyémánt rétegek esetében a $S i V$ centrumokat a nanogyémánt rétegnövesztése során alakítottam ki, addig a kereskedelemből beszerzett nanogyémánt kristályok esetében ionimplantációt, valamint komplex hőkezelési eljárásokat használtam az N3 centrum utólagos kialakítására.

A tömbi kristályoknál általában alkalmazott, jellemzően néhány száz keV-tól akár több tíz MeV-ig terjedő ionenergiák és akár a $10^{22} \mathrm{ion} / \mathrm{cm}^{2}-\mathrm{t}$ meghaladó fluxusok nem igazán alkalmazhatóak a nanoméretü gyémántoknál. Ezen parányi méretű kristályokon vagy „átszalad” az implantálni kívánt ion/molekula, vagy a nagy energia és fluxus miatt visszaállíthatatlanul roncsolódik a szerkezet. Általánosan igaz, hogy az ionenergiák növelésével a roncsolás mértéke is nő. A roncsolás lehet részben, vagy szinte teljesen visszaállítható folyamat, ugyanakkor okozhatja a kristály teljes tönkretételét is. Emellett a nagyenergiájú ionok előállítása sok esetben speciális iongyorsítókat igényel, ami jelentősen megnöveli az implantálás költségét, ebből fakadóan pedig a színcentrumok kialakítása gyakorlati alkalmazások számára gazdaságilag nem gazdaságos.

A fentiek ismeretében a célom az volt, hogy kis ionenergiák alkalmazásával olyan, szélesebb körben elérhető technikákkal alakítsak ki nitrogénhez köthető lumineszcencia centrumokat a detonációs nanogyémánt kristályokban, melyek kevésbé roncsolják a szerkezetet, illetve a későbbiekben egy gazdaságosabb alternatívaként lehetővé tegyék színcentrumok nagy mennyiségü kialakítását nanoméretü gyémánt kristályokban.

Az általános elgondolás az volt, hogy először $\mathrm{He}^{+}$besugárzásnak vetjük alá a mintákat abból a célból, hogy szénvakanciákat, hozzunk létre a kristályszerkezetben, ezzel „,helyet csinálva” a nitrogén szennyezőknek. A He ionok alkalmazásának több előnye is van. Kis méretének köszönhetően kevésbé roncsolja a szerkezetet, mint például a szén ionokkal történő bombázás, továbbá nehezen alakít ki kötéseket, így nem épül be a gyémántba. Második lépésként a mintákat $N_{2}^{+}$ionokkal implantáltuk, melyek nagyobb valószínűséggel eredményezik a több nitrogénből álló centrumok, így az N3 színcentrum kialakulását.

Az implantálás gyakorlati megvalósításához két különböző implantációs technikát alkalmaztunk: a plazma immerziós ionimplantációt (PIII) és a fókuszált ionnyalábos besugárzást (FIB) [105-107]. A minták implantálása együttmüködés keretében történt az MTA TTK Anyag- és Környezetkémiai Intézetében. 
A PIII lényege, hogy a szerkezetbe bejuttatni kívánt szennyező atomot tartalmazó gázt plazmává alakítják, melyre több lehetőség is kínálkozik. A legegyszerübb és emiatt legelterjedtebb eljárás az, hogy a kisnyomású gázelegyet nagyfrekvenciás térrel ionizálják (Penning kisülés). A negatív feszültségre előfeszített tárgy és a plazma között létrejön egy ionokat tartalmazó tértöltési réteg ("sheath"). Az implantáláshoz, azaz az ionoknak a tárgy felülete felé való gyorsításához lehet egyenfeszültséget vagy impulzusokat (akár 100 kV-os) alkalmazni. Ez utóbbi esetben minden impulzus alkalmával a plazma teljes "kiürülése" is elérhető. Ha a plazma elegendően sűrü, a tárgy és a plazma közötti tér jelentős feszültségesést tud fenntartani. Az ionok a semleges atomokkal való ütközéseikhez tartozó szabad úthossznak megfelelően jutnak el a tárgyba, vagy távoznak a vákuumrendszeren keresztül. Az ionok energia- és irányeloszlása a gáznyomástól, az alkalmazott feszültségtől, az ionok töltésállapotától és a tárgy felületének alakjától függ. Az egyszerübb konstrukciójú PIII-nál nincs sem tömegszeparáció, sem ionoptika, azonban az ionáramsürüség nagyon nagy lehet (akár $10^{16} \mathrm{~cm}^{-2} \mathrm{~s}^{-1}$ ) és nagy felületü tárgyak is gyorsan és homogénen besugározhatóak [107]. Ebből kifolyólag megfelelő paramétereket alkalmazva viszonylag egyenletes eloszlásban tudunk szennyezőket bevinni a detonációs nanogyémántból készült vékonyréteg mintákba. A PIII kísérletsorozatok során az implantálást 20 és $30 \mathrm{kV}$ gyorsító feszültséggel és $5 \mu \mathrm{s}$-ig tartó impulzusokkal végeztük. A kisebb gyorsító feszültségnél $\sim 10^{15} \mathrm{ion} / \mathrm{cm}^{2}$ ion fluxust, míg a nagyobbnál $\sim 10^{17} \mathrm{ion} / \mathrm{cm}^{2}$-t alkalmaztunk. A rádiófrekvenciás plazma $(27,13 \mathrm{MHz})$ teljesítménye $50 \mathrm{~W}$ volt.

A PIII módszer mellett a minták implantálására még a FIB módszert alkalmaztuk, mely jelentősen különbözik a PIII technikától. A FIB rendszer 3 fő egységre tagolható: ionforrás, ionoptika és a mintát mozgató tárgyasztal. A módszer szempontjából két alapvető ionforrást különböztetnek meg: fémfolyadék és gáz. Amint az ion bekerül az ionoptikába, hasonlóan az optikában a fény fókuszálására használt lencsékhez, itt megfelelő ion lencséket alkalmazva terelik végig a nyalábot. Jellemzően az ion lencsék nagy precizitással megmunkált középen lyukas korongra hasonlító elektródák. Az ionnyaláb áthalad a korong közepén és felgyorsul az elektromos tér által, majd a tömegszelektálóba kerül. Mivel az ide érkező ionok mindegyike egyforma potenciálra lett felgyorsítva, az eltérő tömeggel, vagy töltéssel rendelkező ionokat nem engedi tovább. Ezután következik a nyalábkioltó, mely arra szolgál, hogy egy elektróda pár segítségével ki-be kapcsolja a nyalábot 10-1000 ns ideig, a célnak megfelelően. Ezután következik a nyaláb fókuszálása akár néhány 10 nm átmérőjü foltra, majd annak pozícionálása a mintára, illetve, ha szükséges, akkor a minta szkennelése [106].

A FIB módszerrel történő implantálás előnye a PIII-vel szemben, hogy az implantálni kívánt ionokat jól lehet pozícionálni, ezért az egyes szemcsékbe hatékonyan tudunk kisebb energiával nitrogént bejuttatni anélkül, hogy nagyon roncsolnánk a teljes szerkezetet. A FIB kísérletek során a gyorsító feszültség $2 \mathrm{kV}$, míg az áram a nitrogénionok esetében $4 \mu \mathrm{A}$, a $H e^{+}$besugárzásnál 4,7 $\mu \mathrm{A}$ 
volt. A FIB kísérletek során az ionnyalábot $\sim 2 \mathrm{~mm}$ átmérőjüre fókuszáltuk és az implantálást a minta raszteres pásztázásával végeztük.

\subsubsection{Az implantált nanogyémánt minták hőkezelése}

A nanogyémánt minták implantálására ugyan viszonylag kis ionenergiákat és fluxusokat használtunk, azonban így is várható valamilyen mértékủ szerkezeti roncsolódás, amely minden esetben végigkíséri az idegen atomoknak a szerkezetbe történő beépülését. Ezért az implantálást követően a mintákat komplex hőkezelési eljárásnak vetettem alá. A komplex hőkezeléssel két feladatot kellett megoldani. Az idegen atomok bejuttatása még nem jelenti azt, hogy a kialakítani kívánt centrum létre is jött. Az N3 centrum, vagyis három nitrogén atomból és egy vakanciából álló komplex hibahely kialakulásához a nitrogén atomoknak és a vakanciáknak találkozni kell. A másik fontos feladat, hogy az implantációval okozott szerkezeti roncsolódást csökkentsük, a hibás kötéseket relaxáltassuk. Foglalkozzunk először a centrum kialakítása céljából végrehajtott hőkezeléssel.

Annak érdekében, hogy beinduljon a vakancia migrációja és megnöveljük a bejuttatott nitrogénionokkal való találkozás (csapdázódás) valószínűségét, ezáltal pedig elősegítsük a centrumképződést, $750{ }^{\circ} \mathrm{C}$ hőmérsékletü hőkezelést alkalmaztam [108, 44]. Emellett, a magas hőmérsékletủ hőkezelés hozzájárul az implantálás által okozott szerkezeti hibák által keltett belső feszültség csökkentéséhez és ezáltal elősegíti a szerkezet gyors relaxációját is. A hőkezeléseket csőkályhában végeztem, ahová a mintákat egy kvarccsőbe helyezve raktam. Mivel ezen a hőmérsékleten a gyémánt már eléghet, ezért ezeknél a kísérleteknél a mintákat tartalmazó kvarccsőben $3,5 \times 10^{-5}$ mbar vákuumot állítottam elő rotációs és olajdiffúziós szivattyúk segítségével. A vákuumban történt hökezelések 2 órán keresztül tartottak.

A nagyvákuumban, $750{ }^{\circ} \mathrm{C}$-on végzett hőkezeléseket egy második, alacsonyabb hőfokon végzett oxidációs folyamat követte. Ennek folyamán a mintákat szabad levegőn, lassú levegőáramlás mellett 5 órán át hőkezeltem $450{ }^{\circ} \mathrm{C}$ fokon. Utóbbi hőkezelésnek az volt a célja, hogy a gyémánt nanoszemcsék rendkívül nagy fajlagos felületén kialakult $\mathrm{sp}^{2}$ hibridizációjú kötéseket eltávolítsam a szerkezetből. Több kísérleti munka során igazolták, ugyanis hogy a $450{ }^{\circ} \mathrm{C}$ fok körüli hőmérsékleteken, levegőn végzett hőkezelés rendkívül hatékony az sp² kötések koncentrációjának csökkentésére [109].

\subsubsection{A nitrogénszennyezés és a vakancia mélységeloszlása}

Annak érdekében, hogy meghatározzuk a $\mathrm{He}^{+}$és $\mathrm{N}_{2}^{+}$besugárzással kialakított szénvakanciák és az implantált nitrogénionok mélységi eloszlását, ezáltal információt szerezzünk arról is, hogy a kísérletileg alkalmazott implantálási paraméterek mellett lehetséges-e komplex nitrogén-vakancia 
hibahelyek kialakítása, kalkulációkat végeztünk a Stopping and Range of Ions in Matter (SRIM) nevü programcsomag segítségével [110]. A program kvantummechanikai módszerek felhasználásával számolja az ionok hatótávolságát, valamint az anyag fékezőképességét. A fékezőképesség nem más, mint a töltött részecskék átlagos egységnyi úthosszra vett energialeadása az anyagban, ami az elektronokkal és az atommagokkal történő Coulomb kölcsönhatások következménye. A SRIM legátfogóbb programja a TRIM (Transport of Ions in Matter), ami egy töltött részecske transzport kód. Ez a kód Monte-Carlo számítást végez, amely nyomon követi az iont a céltárgyban, és részletesen kiszámolja minden (a céltárgyban levő) atommal történő ütközés esetére a leadott energiát. A TRIMmel akár 8 különböző összetételü rétegből álló komplex céltárgyakra is lehet kalkulációkat végezni. A program meghatározza az ionok végső térbeli eloszlását, és minden olyan kinetikus jelenséget, ami az ion energialeadásához kapcsolódik, úgymint a céltárgy károsodása, kialakított vakanciák száma, ionizáció, fonon keletkezés. A számolásokhoz a programcsomag 2012-es verzióját használtam. A számolások során a nanogyémánt sürüségére $3,15 \mathrm{~g} / \mathrm{cm}^{3}$, a kilépési küszöbenergiára $45 \mathrm{eV}$, a felületi kohéziós erőre pedig 4,3 eV értékeket használtam [111-113]. A kalkulációkhoz alkalmazott modell idealizált, mivel homogén rétegként kezeli a nanogyémánt szemcséket, melyek a teljes tartományban azonos szerkezettel rendelkeznek, ezért az implantáció során kapott tényleges mélységeloszlás némileg eltérhet a SRIM programmal meghatározottakétól, azonban egy közelítő képet mégis kaphatunk arról, hogy milyen mélységben alakítunk ki hibahelyeket, illetve juttatunk be nitrogén szennyezőket a mintáinkba.

$\mathrm{Az}$ 5.2. ábra mutatja a SRIM számolások eredményét a PIII és a FIB módszerrel végzett implantációs paraméterekre vonatkozóan. Az ábrán a bejuttatott nitrogén szennyezők, illetve a $H e^{+}$és a nitrogén implantáció által kialakított szénvakanciák mennyiségének mélységeloszlását láthatjuk. Jól látszik, hogy míg a PIII módszerrel implantált minták esetében viszonylag széles mélységi eloszlást kapunk mind a szénvakanciák, mind pedig a bejuttatott nitrogénionok tekintetében, addig a FIB implantálás egy keskeny tartományban fejti ki hatását. Míg a $2 \mathrm{keV}$ ionenergiával implantált minta esetében a nitrogén koncentrációjának maximuma $5 \mathrm{~nm}$ mélység körül található, addig az ionenergia megnövelése - először 20, majd $30 \mathrm{keV}$-re - a koncentráció maximumának eltolódását eredményezi 35 , illetve $50 \mathrm{~nm}$ mélységre. Hasonlóan a nitrogén implantációnál tapasztaltakhoz, a $\mathrm{He}^{+}$ besugárzással keltett szénvakanciák mélységi eloszlásának maximuma szintén a nagyobb értékek felé tolódik az ionenergia növelésével. 

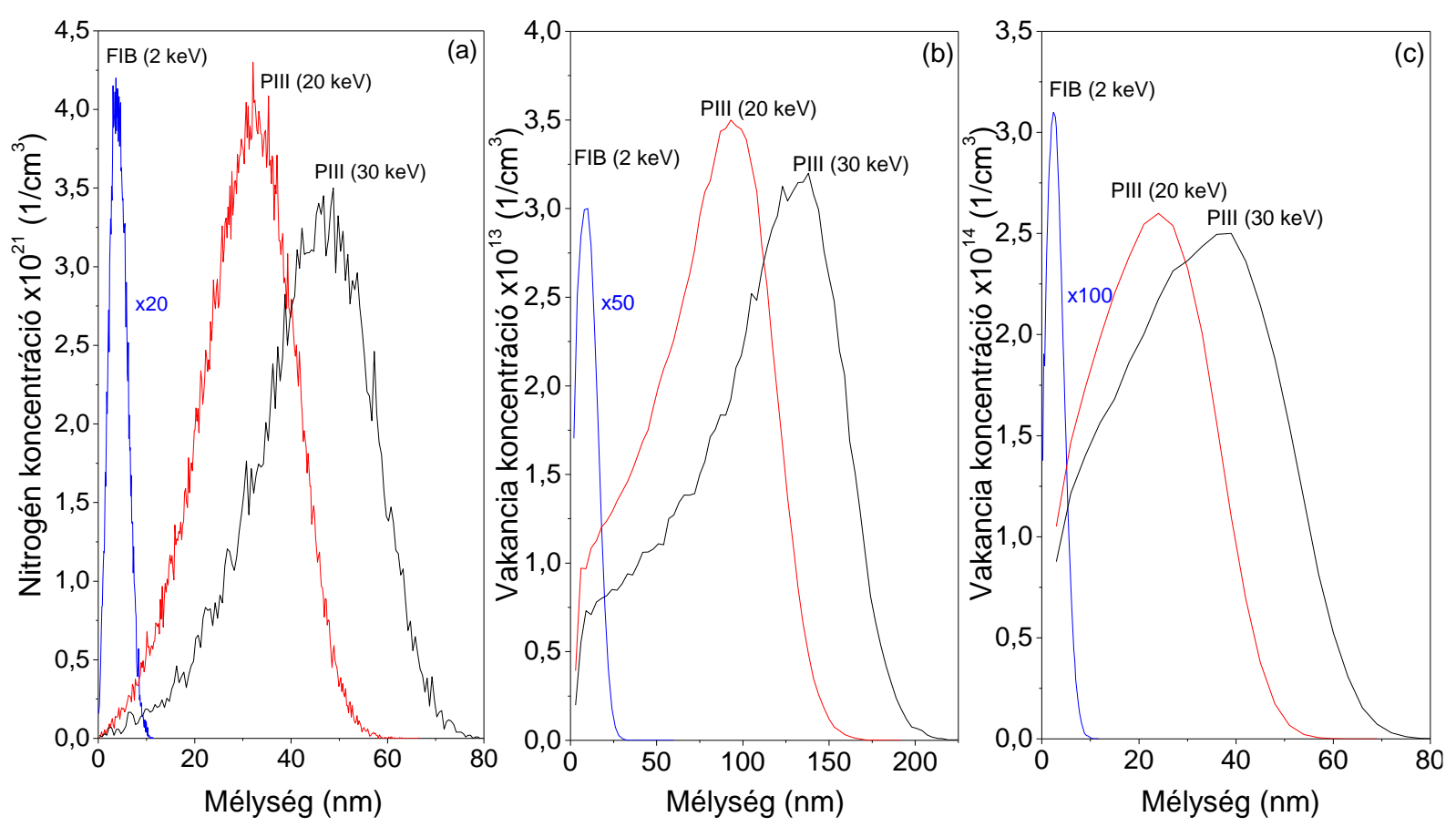

5.2. ábra: A SRIM számolások eredményei a PIII és FIB implantációkra: (a) a beimplantált nitrogén szennyezö mélységeloszlása a nanogyémánt rétegben; (b) a hélium besugárzással kialakitott szénvakanciák mélységi eloszlása és (c) a nitrogén implantáció során létrehozott szénvakanciák koncentrációjának mélységi eloszlása.

Annak érdekében, hogy következtetni lehessen a nitrogén-vakancia komplexumok kialakulásának valószínűségére, meg kell vizsgálni, hogy a megfelelő energiáknál alkalmazott nitrogén implantálás, valamint a vakancia képződés milyen mélységi tartományokban fedi át leginkább egymást. Ideális esetben a nitrogén eloszlás maximuma egybe kellene, hogy essen a szénvakancia eloszlás maximumával. Ez a feltétel a SRIM számolások alapján a FIB paraméterek alkalmazása mellett teljesül a leginkább. Azonban az említett hibahelyek kialakulása a PIII esetekben is feltételezhető, mivel maga a nitrogén implantáció is jelentős mennyiségű szénvakancia keltéssel jár, melyek mélységi eloszlása azonos az implantált nitrogénionokéval, így jelentősen hozzájárul a nitrogén-vakancia hibahely komplexumok kialakulásához. Ennek alapján kijelenthető, hogy a SRIM kalkulációk alapján számolt vakancia és nitrogénatomok mélységeloszlása arra utal, hogy az alkalmazott ionenergiákkal kialakíthatóak nitrogénhez köthető komplex hibahelyek a gyémántkristályban. A számolásokból kapott eloszlásokból arra is következtetni lehet, hogy a FIB módszer során alkalmazott paramétereknél nagyobb valószínűséggel várható a nitrogénhez köthető centrum kialakulása, illetve, mivel ebben az esetben a centrumképződés a felülethez közeli tartományban valószínűsíthető, ezért a roncsolás mértéke kisebb lehet, mint a PIII módszernél. 


\subsubsection{Nanogyémánt vékonyrétegek előállítása MW CVD módszerrel}

Ahogy az már korábban is említésre került, a gyémánt kristályok előállításának egy másik, széles körben elterjedt módszere az MW CVD, azaz a mikrohullámmal létrehozott kisnyomású plazmából történő kémiai gőzfázisú leválasztás. Az MW CVD módszer előnye a detonációs módszerrel szemben, hogy közvetlenül a kristály növesztése során lehetőség van különböző szennyező atomok bevitelére és így színcentrumok kialakítására a nanogyémánt szerkezetben [114]. Az 5.3. ábrán a nanogyémánt vékonyrétegek leválasztására használt MW CVD berendezés sematikus rajza látható.

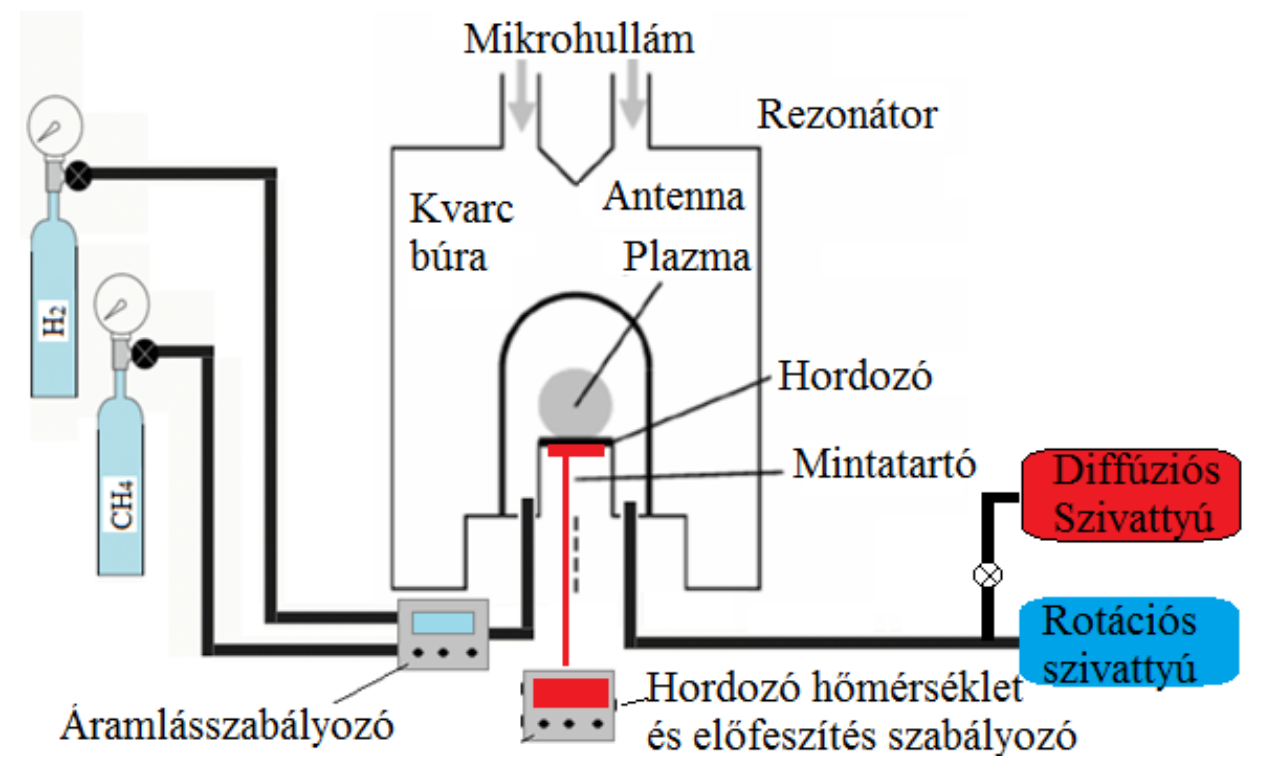

5.3. ábra: Az MW CVD gyémántleválasztó berendezés sematikus rajza.

Az MW CVD növesztés során a forrásgázok keveréke beáramlik a kvarc burával határolt reaktortérbe, ahol a hullámvezető által becsatolt mikrohullámú teljesítmény hatására aktiválódik. A kialakult plazmában különböző reakciótermékek jönnek létre, melyek egyaránt tartalmaznak semleges és ionizált molekulákat, továbbá gyököket. Ezek a részecskék konvekció és diffúzió útján eljutnak a hordozó felületéig. A felületen többfajta folyamat játszódik le egyidejűleg (adszorpció, diffúzió, kémiai reakciók, deszorpció), emiatt a felület közelében a kémiai összetétel eltérő lehet a plazmában található kémiai összetételtől [115]. Mindezen komplex folyamatok eredményeként gyémánt és más szén módosulatok leválása és marása zajlik párhuzamosan. A kémiai folyamatokat a gáztérben a hidrogén disszociációja dominálja, amely az elektronokkal való ütközés eredménye. Emellett az atomos hidrogén és szénhidrogének közötti reakciók fontosak még. A szénhidrogének hidrogénnel való reakciójának karakterisztikus ideje lényegesen rövidebb, mint a növekedési felület eléréséhez szükséges idő, így ezek a reakciók egyensúlyba kerülnek. Az említett folyamatok következtében a felület közelében kisebb nyomáson a $\mathrm{CH}_{3}, \mathrm{CH}_{4}, \mathrm{C}_{2} \mathrm{H}_{2}$ és a $\mathrm{C}_{2} \mathrm{H}_{4}$, míg nagyobb nyomástartományoknál 
a C, $\mathrm{CH}, \mathrm{CH}_{2}, \mathrm{C}_{2}$ és $\mathrm{C}_{2} \mathrm{H}_{4}$ szénhidrogének fordulnak elő legnagyobb arányban. Egyes szerzők szerint a növekedésben kulcsszerepe a $\mathrm{C}_{2} \mathrm{H}_{2}$, míg mások szerint a $\mathrm{CH}_{3}$ gyököknek van [116-118].

Az MW CVD módszerrel végzett gyémánt leválasztási folyamat jól kézben tartható, ezért lehetőség van a leválasztási paraméterek (gáz összetétel, gáz beáramlási sebesség, leválasztási nyomás, mikrohullámú teljesítmény, hordozóhőmérséklet, stb.) precíz változtatására. Az említett leválasztási paraméterek közül, a kialakuló réteg tulajdonságait tekintve elsősorban a hordozóhőmérsékletnek, a forrásgáz metánkoncentrációjának, továbbá a becsatolt mikrohullámú teljesítménynek van a legnagyobb jelentősége. Az utóbbi paraméter változtatására azonban csak a nagyobb teljesítménnyel rendelkező mikrohullámú források esetében van lehetőség. Az általunk használt rendszer mikrohullámú generátora csak $1200 \mathrm{~W}$ maximális teljesítménnyel képes müködni, ezért a kísérleteim során a hordozóhőmérsékletet és a forrásgáz metántartalmát változtattam szisztematikusan és ezáltal eltérő morfológiával, kötésszerkezettel rendelkező SiV centrumot tartalmazó nanogyémánt rétegeket állítsak elö.

Az MW CVD folyamat során a gyémántréteget valamilyen hordozóra növesztik, ami a legtöbb esetben szilícium lapka. Ahhoz, hogy gyémántkristályok kezdjenek növekedni a nem gyémánt hordozón, gyémánt magokat, kristálykezdeményeket kell kialakítani a felületen. Ez történhet a felület gyémánt porral történő polírozásával, vagy ultrahangos rázatással gyémánt nanokristályokat tartalmazó szuszpenzióban. Fontos módszer az előfeszítéssel segített nukleáció, amely során negatív (jellemzően 150-300 V) feszültséget kapcsolnak a hordozóra és a szénhidrogének arányát pedig megnövelik a gáztérben annyira, hogy előfeszítés nélkül már amorf szénréteg képződne. A módszer előnye az egyéb nukleációs technikákkal szemben, hogy sokkal homogénebb és viszonylag sűrü magképződést tesz lehetővé. Ezért a nanogyémánt minták készítése során előfeszítéses nukleációt alkalmaztam $150 \mathrm{~V}$ negatív előfeszültség mellett. A nukleációt követően a megfelelő leválasztási paraméterek mellett történik a réteg növesztése.

A plazma kémiai összetétele a gyémántréteg növekedése szempontjából 2 fö komponensre bontható. Az egyik a metánból keletkező különböző szénhidrogének, melyek a réteg növekedését táplálják, míg a másik komponens a hidrogénionok, melyek marják a növekedő felületet, így drasztikusan lecsökkentve a nem $\mathrm{sp}^{3}$ kötésü szénszerkezetek növekedési sebességét. Kis metánkoncentráció és nagy hidrogéntartalom mellett a növekedési sebesség kicsi. Általában ezen növekedési környezetben a forrásgáz mennyisége nem elég, hogy a különböző növekedési irányok versenyezzenek, ezért prekurzor limitált rezsimnek is nevezik. Jellemzően a kialakuló réteg jól textúrált, a felületet a domináns kristálysíkok uralják. A metánkoncentráció növelésével a prekurzor limitált növekedési környezet átvált egy olyan rezsimre, ahol a növekedést az elérhető kristályfelületek limitálják. Ilyenkor a nagy metánkoncentráció következtében a plazmában található felület közeli 
szénhidrogéneknek csak egy része tud bekötni és hozzájárulni a kristályok növekedéséhez, mivel a szabad felületek száma korlátozott. Az ilyen feltételek mellett növesztett rétegek jellemzően finom, apró szemcsével borítottak, kitüntetett kristálytani iránnyal vagy egyáltalán nem rendelkeznek, vagy az nehezen meghatározható.

A hordozóhőmérséklet hatással van a kialakuló réteg szerkezetére, mivel a felületen, valamint annak közelében lejátszódó reakciók kinetikáját befolyásolja. Növekedés során, termodinamikai egyensúlyban (amikor a hidrogénnel lezáródó felületi $\mathrm{sp}^{3}$ szén kötések és a keletkező szabad, vagy lógó felületi $\mathrm{sp}^{3}$ szén kötések száma megegyezik) a szabad $\mathrm{sp}^{3}$ szénkötések száma csak a hordozóhőmérséklet függvénye és független a hidrogén koncentrációtól. A hordozóhőmérséklet változása a felületen lévő szabad $\mathrm{sp}^{3}$ kötések számának változását, illetve a hidrogén általi marási sebességet is befolyásolhatja [119].

A nanogyémánt vékonyrétegeket $1200 \mathrm{~W}$ mikrohullámú teljesítménnyel, $100 \mathrm{sccm}$ teljes gázbeáramlási $\left(\mathrm{H}_{2}+\mathrm{CH}_{4}\right)$ sebesség és $4 \mathrm{kPa}$ leválasztási nyomás mellett állítottam elő különböző forrásgáz összetételeknél és hordozó hőmérsékleteknél, melyet a dolgozat végén a 12.2. függelékben összegzek. Minden egyes leválasztási folyamat azonos ideig (2 óra) tartott. A leválasztott rétegek vastagságát in situ lézerinterferometrikus módszerrel mértük, melyhez fényforrásként egy He-Ne lézer 633 nm-es vonala szolgált. Az egyes mintákra meghatározott értékeket a táblázat negyedik oszlopa tartalmazza. Itt tüntetem fel az egyes vékonyrétegekre meghatározott átlagos szemcseméreteket is, melyről bővebben az 5.2.2. alfejezetben beszélek.

A fentiekben részleteztem a gyémántréteg növekedését és annak változását a leválasztási paraméterekkel, a továbbiakban pedig áttérek a szilícium szennyező bevitelére a nanogyémánt rétegbe. Ahhoz, hogy a $\mathrm{SiV}$ centrumot kialakítsuk a gyémánt mátrixban, biztosítanunk kell a szilícium jelenlétét a plazmában. Szilícium forrásként a leggyakoribb esetben maga a hordozó szolgál, ha a leválasztás szilícium hordozóra történik, vagy esetenként még a reaktorteret határoló kvarc búra.

A kísérleteinkben szilícium lapkára növesztettük a rétegeket, de a plazmatérbe egy további Si lapkát is elhelyeztünk. Ez a lapka nem volt előfeszítve, tehát nem indult meg rajta a gyémánt nukleáció, így folyamatosan szabad szilícium felületet biztosított. A rétegnövesztés során az agresszív plazma marja a szilíciumot tartalmazó Si forrást is, melynek következtében a szilícium atomok bekerülnek a plazmatérbe, ahonnan beépülnek a növekvő kristályrácsba, majd végül a 3.3.1. alfejezetben ismertetett modell alapján kialakul az osztott vakancia szerkezet. Mivel a centrum vakanciát is tartalmaz és ezáltal „lágy” centrumként is viselkedhet, hasonlóan az $N V$ centrumokhoz. A „lágy” centrumokra jellemző, hogy sokkal érzékenyebbek a közvetlen környezetük szerkezeti sajátosságaira, így várható, hogy a nanogyémánt mátrix-anyag szerkezetének a módosulása mikro-, vagy nanoskálán hatással van a beépülő centrumok lumineszcencia tulajdonságaira. Ennek fordított megközelítéseként azt várhatjuk, 
hogy a nanogyémánt réteg, mint mátrix-anyag szerkezetének mikro-, vagy nanoskálájú változtatásával testre szabhatjuk, vagy optimalizálhatjuk a centrum kívánt emissziós paramétereit. Ezen megfontolások vezérelték azokat a kutatásaimat, amelyek során részletesen tanulmányoztam a $\mathrm{SiV}$ centrum emissziós tulajdonságainak a változását azokban a nanogyémánt vékonyrétegekben, amelyeket a hordozó hőmérsékletének, valamint a forrásgáz metán tartalmának, mint leválasztási paramétereknek a változtatásával állítottam elő.

\subsection{A minták minősítése}

A kutatásaim során használt nanogyémánt minták minősítésére, kötésszerkezetük jellemzésére a Raman-spektroszkópiai módszert alkalmaztam. Pásztázó elektronmikroszkópos vizsgálatok történtek az MW CVD módszerrel készült nanogyémánt vékonyrétegek textúrájának, szemcseméret eloszlásának jellemzésére. A kialakított színcentrumokat fotolumineszcencia spektroszkópiai módszerrel tanulmányoztam. Ezzel a gyémántban kialakított színcentrumok tanulmányozásában hatékony módszerrel külön alfejezetben foglalkozom. A következőkben az elöbb említett három vizsgálati módszer alapjait, valamint a segítségükkel kapott kísérleti eredményeket mutatom be a detonációs nanogyémánt mintákra és az MW CVD módszerrel készült nanogyémánt rétegekre vonatkozóan.

\subsubsection{Raman-spektroszkópia}

A Raman-spektroszkópia jól ismert, roncsolásmentes vizsgálati módszer, melyet széles körben és hatékonyan alkalmaznak a különböző szénszerkezetek kötésszerkezetének feltérképezésére, így jól használható a gyémánt szerkezetek, ezen belül is a nanogyémánt struktúrák jellemzésére is. A Ramanspektroszkópia jellemzően a monokromatikus fény valamely közegben való szóródását követően a detektált spektrumban megjelenő azon komponenseket vizsgálja, melyek frekvenciája különbözik a beesőtől. Maga a Raman-szórás egy kétfotonos folyamat, mely során a gerjesztő $\omega_{0}$ frekvenciájú foton elnyelődik, és egy tőle eltérő frekvenciájú $\omega_{S}$ szórt foton keletkezik. Általánosságban kijelenthető, hogy az egyes Raman-szórási komponensek eltolódása (a beeső/gerjesztő fény frekvenciájához képest) $\omega_{R}=\omega_{0}-\omega_{S}$ nem függ a gerjesztő fény frekvenciájától $\omega_{o}$, ez a vizsgált közegre jellemző tulajdonság. Abban az esetben, ha a szórt foton energiája kisebb a gerjesztő foton energiájánál $\left(\omega_{S}<\right.$ $\omega_{0}$ ), a folyamat Stokesi. Fordított esetben, azaz ha a szórt foton energiája nagyobb a gerjesztő foton energiájánál $\left(\omega_{S}>\omega_{0}\right)$, anti-Stokesi folyamatról beszélünk. Míg előbbi egy elemi gerjesztés keletkezésével, addig utóbbi annak megsemmisülésével jár. Kristályoknál ezek az elemi gerjesztések 
fononok és jellemzően csak a Brillouin zóna középpontjában találhatóak vesznek részt a szórási folyamatban.

Mivel a gyémántrács Brillouin zónájának középpontjában egyetlen, háromszorosan degenerált Raman-aktív optikai módus található $T_{2 g}$ szimmetriával, ezért a tiszta gyémánt egykristály Ramanspektruma egyetlen keskeny sávból áll, melynek csúcshelyzete $1332 \mathrm{~cm}^{-1}$-nél található. A nanoméretü gyémánt kristályok Raman-szórási spektrumai jellemzően más szórási sávokat is tartalmaznak az 1332 $\mathrm{cm}^{-1}$-nél található gyémánt csúcson kívül. Ezek a szórási sávok általában 1000 és $2000 \mathrm{~cm}^{-1}$ között találhatóak és különböző nem gyémánt kötésekhez, leginkább $\mathrm{sp}^{2}$ hibridizációjú szénatomokból álló szerkezetekhez köthetőek, melyek a nanoméretű kristályok felületén, vagy a vékonyrétegek esetében a szemcsék közötti határrétegben találhatóak. A leggyakoribb esetben mikrokristályos grafitra, vagy grafit klasztereket tartalmazó amorf szénre jellemző úgynevezett G és D szórási sávok tünnek fel a nanoméretű gyémánt kristályok Raman-spektrumaiban. Míg előbbi az $\mathrm{sp}^{2}$ hibridizációjú szénatom párok egymáshoz viszonyított síkbeli nyújtórezgéséhez rendelhető, addig utóbbi a szintén $\mathrm{sp}^{2}$ alkotta aromás, gyürüs elrendezésű szerkezetek lélegző módusához tartozik. A G sáv $1580 \mathrm{~cm}^{-1}$ körül található grafitos klasztereknél, a D sáv pedig $1355 \mathrm{~cm}^{-1}$ környékén jelentkezik a Raman-szórási spektrumban. Utóbbi pozíciója klaszterméret függő és a pozíciója változhat a gerjesztő energia függvényében [113]. Az említett két sávon kívül a nanoméretű gyémánt Raman-spektrumában szinte minden esetben megfigyelhető két, egymással kapcsolatban álló szórási sáv 1150 és $1450 \mathrm{~cm}^{-1}$ körül. A jelenleg általánosan elfogadott nézet szerint a két sáv, melyet gyakran a nanogyémánt „ujjlenyomat” sávjaiként is emlegetnek, a gyémántszemcsék felületén található transz-poliacetilén $v_{1}$ és $v_{3}$ rezgéseihez rendelhetöek [120].

A dolgozatban szereplő minták minősítésére, jellemzésére, továbbá a különböző kezelések hatására a kötésszerkezetben bekövetkezett változások nyomonkövetésére a Raman-spektroszkópiai vizsgálatokat alkalmaztam. A méréseket Leica DM/LM mikroszkóppal összeépített Renishaw 1000 típusú Raman-spektrométeren végeztem, melynek sematikus felépítése az 5.6. ábrán látható.

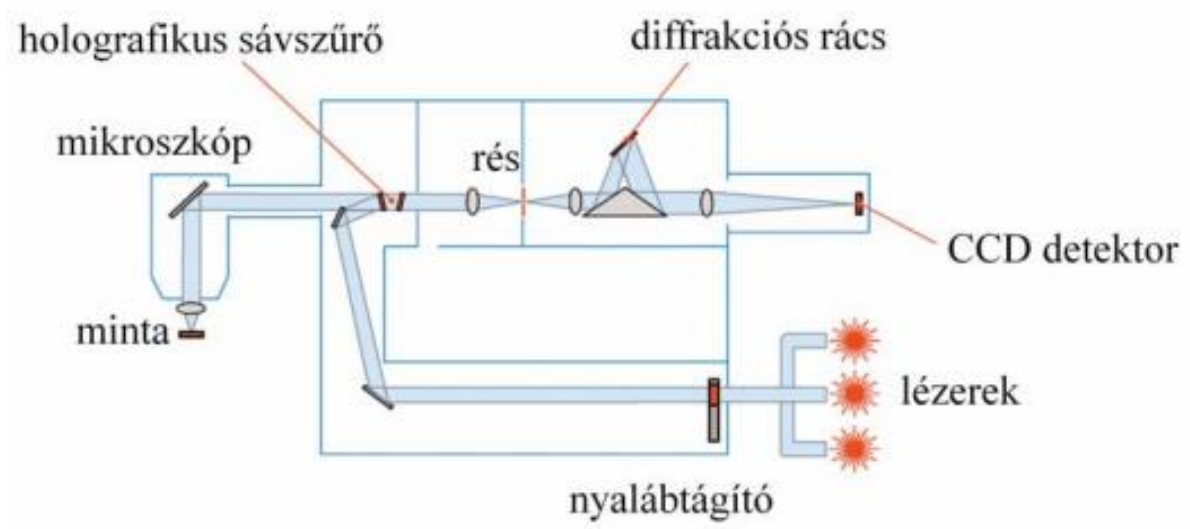

5.4. ábra: A Renishaw 1000 Raman-spektrométer felépitésének sematikus rajza 
A készülékben a szórt fény hullámhossz szerinti felbontása egy speciális holografikus szürő és egy monokromátor segítségével történik. A holografikus sávszürő rendeltetése, hogy kiszürje a spektrumból a gerjesztő lézer vonalát. Mivel a holografikus rács egy adott hullámhossz kiszürésére van optimalizálva, ezért különböző gerjesztési hullámhosszak alkalmazása során különböző holografikus rácsok alkalmazása szükséges, melyek általában a gerjesztő hullámhosszt a $\pm 100 \mathrm{~cm}^{-1}$-es környezetével együtt képesek blokkolni a szórt spektrumban. A mérések során a gerjesztéshez egy Spectra-Physics Ar ion lézer 488 nm-es vonalát használtam, melynek teljesítménye $1 \mathrm{~W}$. A gerjesztőfény intenzitása a készülékbe épített szürke szürökkel csökkenthető 50, 25, 10, és 1\%-ra. Miután a gerjesztő nyaláb áthalad egy nyalábtágítón, tükrök segítségével a mikroszkópba kerül, ahol megtörténik annak leképezése a mintára a megfelelő objektívek által. A mérések során használt objektívek 25x, 50x, 100x nagyítással rendelkeznek. A legtöbb esetben használt 100x nagyítással rendelkező objektív alkalmazása esetén a lézerfolt átméröje megközelítőleg 1 mikrométer volt. A visszaszórt fény benne a gerjesztő lézer és a gerjesztett térfogat Raman-szórási jelével a leképezést végző lencsén keresztül begyüjtésre kerül, majd eljut a holografikus rácsig, ami a gerjesztő fényt kiszüri. Ezt követően a nyalábot egy kollimáló lencse leképezi a monokromátor előtti résre, melynek szélessége szabályozható. A mérések során a résszélesség minden esetben 15 mikrométer volt, ami $1 \mathrm{~cm}^{-1}$ feloldóképességet tesz lehetővé a 488 nm hullámhosszú gerjesztő lézer alkalmazása mellett. A monokromátor bemenő rését követően a nyaláb a diffrakciós rács segítségével felbontásra kerül, majd a megfelelö hullámhossztartomány egy lencse segítségével fókuszálódik a detektorra. A detektor egy 576x20 pixeles töltéscsatolt CCD kamera, mely előtt egy a fényképezőgépekhez hasonló zárszerkezet található, amellyel a mérési idő szabályozható. A mérési időt az érzékelő túltelítődése korlátozza.

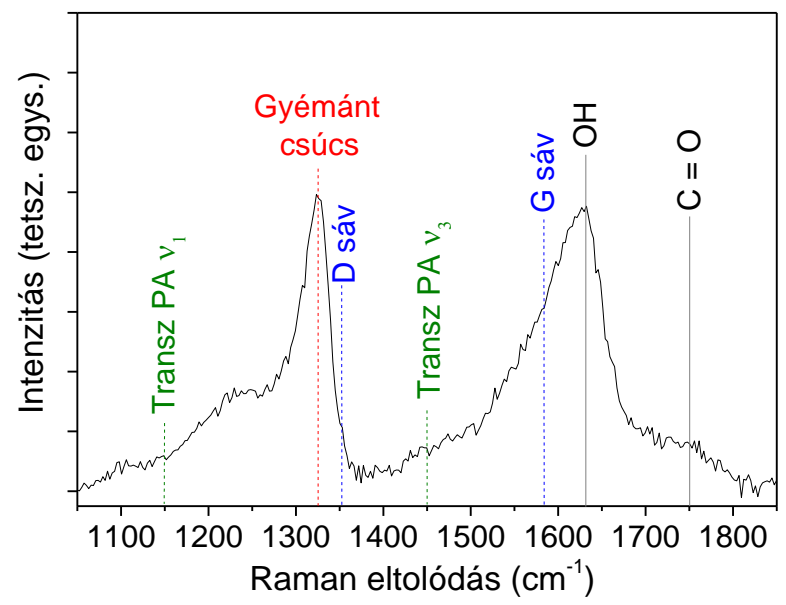

5.5. ábra: Az implantációs kisérletekhez használt detonációs nanogyémánt minta $488 \mathrm{~nm}$ lézerhullámhosszal gerjesztett Raman-szórási spektruma.

Az 5.5. ábrán az implantációs kísérletek során használt, detonációs módszerrel készült nanogyémánt por Raman-szórási spektruma látható az 1050-1850 cm² hullámszámtartományban. 
Annak ellenére, hogy a spektrum jelentősen eltér a gyémánt egykristály Raman-szórásától, a szerkezete tipikusnak mondható az irodalomban található nanogyémánton mért spektrumokkal összevetve [104]. A spektrum legintenzívebb csúcsa az $1324 \mathrm{~cm}^{-1}$-nél található karakterisztikus gyémánt szórási sáv, mely $8 \mathrm{~cm}^{-1}$-el a kisebb hullámszámok felé tolódott, továbbá kissé kiszélesedett az egykristály gyémánt szórási sávjához képest. A megfigyelt különbségek nagy valószínüséggel az eltérő előállítási/keletkezési körülményekből fakadnak. A detonáció során a nanokristályok keletkezése nagyságrendekkel gyorsabban lezajlik, mint a természetes egykristályok kialakulása, aminek következtében a szerkezet relaxációja csak részleges, így maradék belső feszültséggel rendelkezik. A belső feszültség pedig egyaránt okozhatja a gyémánt sáv kiszélesedését és eltolódását [104]. Egy másik lehetséges magyarázat lehet még a kvantum bezártság, mely a fononok élettartamának csökkenésével van kapcsolatban azoknál a nanogyémánt kristályoknál, melyek mérete kisebb 20 nm-nél [121]. Bár a fonon élettartam csökkenése által előidézett vonalkiszélesedés és eltolódás csak a $10 \mathrm{~nm}$-nél kisebb kristályok esetében válik igazán szignifikánssá, a detonációs módszerrel előállított nanogyémánt minták esetében, melyekben a nanokristályok egy része ebbe a mérettartományba esik, okozhatja a gyémánt Raman-szórási sáv paramétereiben tapasztalt eltéréseket [122].

Annak ellenére, hogy a gyártó megadja a nanogyémánt kristályok átlagos szemcseméretét, egyfajta kontroll céllal közelítőleg megbecsültem a minta szemcseméret eloszlását és átlagos szemcseméretét a Raman-spektrum gyémánt szórási sávjának analíziséből. Mivel a detonációs módszerrel előállított gyémánt mintát alkotó nanokristályok mérete egy bizonyos tartományon belül változik, azaz méreteloszlással jellemezhető, ezért a mért Raman-spektrum egyaránt tartalmazza a kisebb és nagyobb szemcsék hozzájárulását. A korábbi eredmények azt mutatják, hogy a gyémánt Raman-szórási sávjának vonalkiszélesedése $\Gamma$ (FWHM), melyet a fonon élettartam határoz meg, függ a kristálymérettől. A $\Gamma=A+\frac{B}{L^{2}}$ összefüggésből meghatározható a kristály mérete $(L)$. Az egyenletben az $A$ a tömbi gyémántkristály Raman-vonalának kiszélesedését jelöli, míg $B$ anyagfüggő paraméter, amely a vizsgált anyag Raman-vonalkiszélesedésének a kristálymérettől való függését jellemzi. A kalkulációk során $A=11,0 \mathrm{~cm}^{-1}$ és $B=491,25 \mathrm{~cm}^{-1} \mathrm{~nm}^{2}$ értékeket használtam, míg az egyes komponensek félértékszélességének meghatározását négy Lorentz görbével történő illesztéssel végeztem (5.6. ábra) [121]. A négy Lorentz görbe használatát az illesztés jóságát jellemző $\chi^{2}$ paraméter indokolta, mely ezáltal elérte a 0,9992-t. A számítások alapján a detonációs nanogyémánt 4,6 és 18,8 nm közötti nanokristályokat tartalmaz, az átlagos kristályméret pedig megközelítőleg 12 nm (egy Lorentz használata esetén ez az érték 10,9 nm, azonban az illesztés jósága mindössze $\chi^{2}=0,86$ ), mely értékek jó egyezést mutatnak a gyártó által megadott paraméterekkel. 


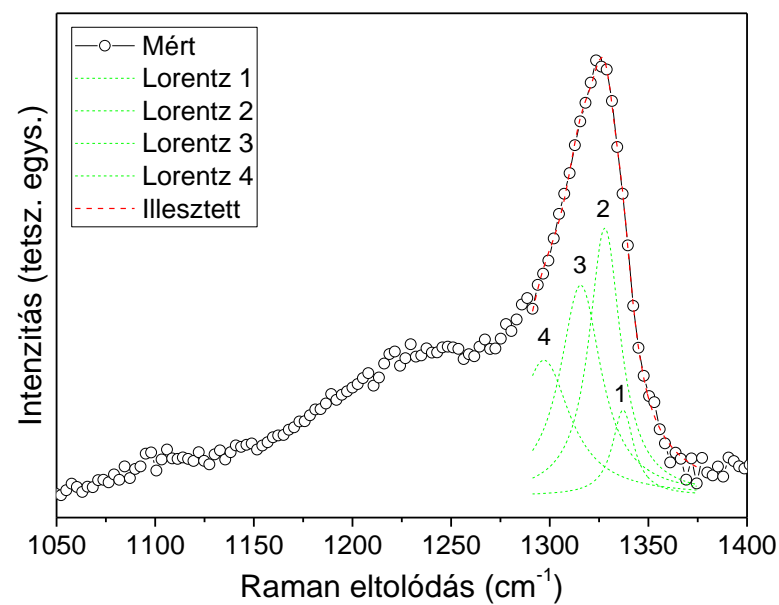

5.6. ábra: A különbözö méretü nanogyémánt kristályok illesztéssel meghatározott hozzájárulása a gyémánt csúcshoz a kísérletileg vizsgált minta Raman-szórási spektrumában.

A gyémánt sávon kívül $1640 \mathrm{~cm}^{-1}$-nél látható egy széles strukturált szórási sáv, mely a felülethez kötött $\mathrm{OH}$ csoportokhoz rendelhető. Ennek a széles sávnak a kisebb hullámszámú oldalán vállként jelentkezik a G sáv $1580 \mathrm{~cm}^{-1}$ körül, mely a korábban említett D sávval (a mi mintánk Ramanspektrumában $1355 \mathrm{~cm}^{-1}$ ) együtt némi $\mathrm{sp}^{2}$ tartalomra utal a mintában. Annak ellenére, hogy ezen szórási sávok relatív intenzitása összemérhető a gyémánt csúcsáéval, az $\mathrm{sp}^{2}$ tartalomra nem lehet mennyiségi becslést végezni. Azonban annak ismeretében, hogy az $\mathrm{sp}^{2}$ szerkezetek szórási keresztmetszete [122] az alkalmazott $488 \mathrm{~nm}$ gerjesztő hullámhossznál sokkal nagyobb, mint a gyémánté kijelenthető, hogy a mintánk $\mathrm{sp}^{2}$ tartalma lényegesen kisebb, mint amire a spektrumban látható szórási sávok intenzitásának arányából elsőre következtetnénk és azonos intenzitásarányokkal rendelkezik, mint az UV lézerrel $(3,815 \mathrm{eV})$ vizsgált hasonló nanogyémánt szerkezetek [121]. Továbbá, a spektrumban megtalálhatóak a nanoméretű gyémántkristályokra jellemző „ujjlenyomat” sávok 1150 és $1450 \mathrm{~cm}^{-1}$-nél, melyek transzpoliacetilén láncokhoz rendelhetőek, valamint a hibás gyémánt rácsszerkezethez rendelhető, vállként jelentkező szórási sáv $1250 \mathrm{~cm}^{-1}$ körül [123]. Emellett a felületen található oxigénre utaló szennyezések is kimutathatók, melyre az $1750 \mathrm{~cm}^{-1}$-nél lévő kisintenzitású szórási sáv jelenléte mutat.

A detonációs gyémánt előzőekben ismertetett Raman-vizsgálata a mátrix-anyagként szolgáló gyémánt minősítését jelenti. Az MW CVD-vel előállított nanogyémánt vékonyrétegek már a $\mathrm{SiV}$ színcentrumot is tartalmazzák, így azok Raman-szórási spektrumai már egy szándékosan szennyezett nanogyémánt réteg Raman-szórását mutatják, melyet $800-2000 \mathrm{~cm}^{-1}$ hullámszámtartományban vizsgáltam. A kapott eredményeket két reprezentáns sorozaton mutatom be, amelyekből jól követhető a forrásgázban lévő metántartalom, valamint a hordozóhőmérséklet változásának hatása a nanogyémánt vékonyréteg atomi kötésszerkezetére és így a Raman-szórási spektrumokra (5.7. ábra). 
A nanogyémánt rétegek szerkezeti felépítésüket tekintve nanoméretü kristályokból, az egyes kristályokat borító felületi határrétegböl és a szemcséket összekötő amorf szénfázisból állnak. Ezen szerkezeti struktúrákra jellemző szórási sávok 1100 és $1800 \mathrm{~cm}^{-1}$ között találhatóak és jellemzően a gyémánt csúcson kívül a különböző térbeli elrendezésű $\mathrm{sp}^{2}$ szénszerkezetekhez rendelhetőek, melyekről már a fejezet elején szó volt. Az 5.7. ábrán látható spektrumok mindegyikében jól beazonosítható a gyémánt szórási csúcsa $1333 \mathrm{~cm}^{-1}$ körül, azonban a pontos pozíciója változik az egyes sorozatokon belül. Lorentz görbével végzett illesztéssel meghatároztam a gyémánt szórási sávjának pozícióját és kiszélesedését az egyes mintákra. A gyémánt Raman-sávjának csúcshelyzete 1332,9 és $1335,4 \mathrm{~cm}^{-1}$ között változik a különböző $\mathrm{CH}_{4}$ koncentrációnál leválasztott sorozaton belül, míg a különböző hordozóhőmérsékleten leválasztott mintasor esetében 1333,5 és $1335,5 \mathrm{~cm}^{-1}$ között. Az említett leválasztási paraméterek a gyémánt Raman-szórási sávjának kiszélesedését is erősen befolyásolják, mely a különböző $\mathrm{CH}_{4}$ koncentrációnál leválasztott sorozaton belül 15,1 és $21,6 \mathrm{~cm}^{-1}$, illetve az eltér hodozóhőmérsékletek alkalmazása során 15,2 és 18,2 $\mathrm{cm}^{-1}$ közötti félértékszélességet eredményez.
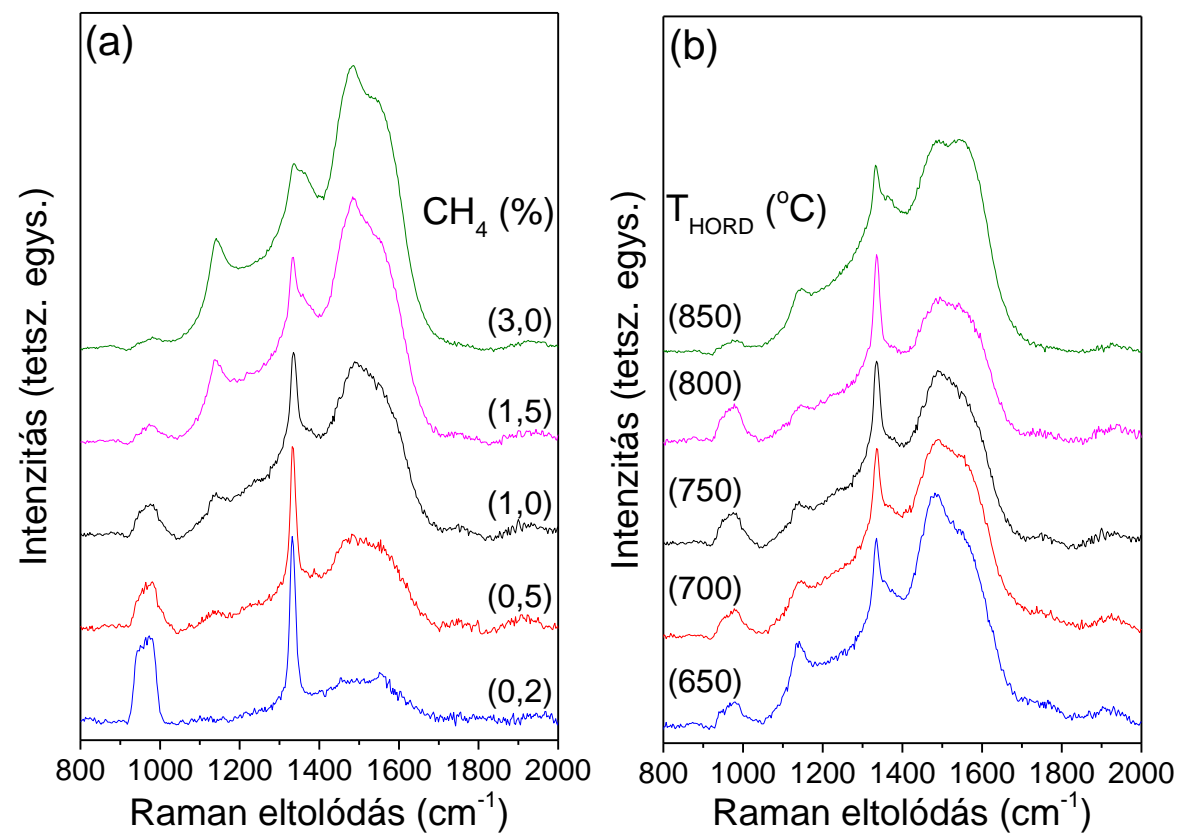

5.7. ábra: A leválasztott nanogyémánt rétegek 488 nm lézerhullámhosszal gerjesztett Raman-szórási spektrumai: (a) $750^{\circ} \mathrm{C}$ hordozóhőmérsékleten és a forrásgáz különbözö metánkoncentrációinál; (b)

$1 \% \mathrm{CH}_{4}$ koncentrációnál, de különbözö hordozóhömérsékleten.

$\mathrm{Az}$ 5.7. ábra (a) részén látható szórási spektrumok nagyon szemléletesen mutatják a nanogyémánt rétegek kötésszerkezetének változását a forrásgáz metántartalmával. Fokozatosan erősödnek a nem gyémánt kötések szórásához rendelhető sávok az 1100-1200 cm , valamint az 1400$1600 \mathrm{~cm}^{-1}$ hullámszámtartományban. További változás a gyémánt szórási csúcs közelében $\sim 1360 \mathrm{~cm}^{-}$ 
1'-nél kifejlődő szórási sáv, amelynek növekedése a gyémánt sáv deformációjához vezet a forrásgáz nagy metánkoncentrációjánál. A fokozatosan megjelenő szórási sávok pozícióját és félértékszélességét a Raman-szórási spektrum dekompozíciójával határoztam meg és a csúcspozíciókra kapott eredményeket az 5.1. táblázatban foglaltam össze.

Az $1130 \mathrm{~cm}^{-1}$ és $1460 \mathrm{~cm}^{-1}$-nél lévő sávok a nanogyémánt „ujjlenyomat” Raman-szórási sávjai, amelyek szórási intenzitása erősödik a forrásgáz metántartalmával. Ennek oka, hogy egyre kisebb szemcsék alkotják a réteget, amelyek egyre nagyobb fajlagos felületén nő a poliacetilén típusú $\mathrm{sp}^{2}$ kötések száma, és így szórási intenzitásuk is. Az 1560-1580 $\mathrm{cm}^{-1}$-nél és az $\sim 1360 \mathrm{~cm}^{-1}$-nél található G és D szórási sávok -az aromás gyürüs klaszterek nyújtó és lélegző módusai - a szemcsék közti amorf szén tartomány szórását reprezentálják.

Az 5.7. ábrán látható még egy széles szórási sáv $\sim 970 \mathrm{~cm}^{-1}$ körül, ami a vékonyrétegeknél használt Si hordozó kétfononos Raman-szórási csúcsa [124]. Ennek a sávnak az intenzitása jól láthatóan csökken a forrásgáz metánkoncentrációjának növekedésével. Ennek oka elsősorban nem csak a nanogyémánt réteg növekvő vastagsága, hanem döntően a kötésszerkezetének a változása. A gyémánt ugyanis átlátszó a 488 nm-es lézer hullámhosszra és a Si lapka által visszaszórt fényre is, azonban az $\mathrm{sp}^{2}$ szerkezetek kifejlődése növeli az optikai elnyelést a gyémánt tilos sávjánál kisebb energiáknál, ezáltal csökkentve a Si hordozó Raman-szórásának láthatóságát a spektrumban.

5.1. táblázat A $750^{\circ}$ C hordozóhömérsékleten és különbözö metánkoncentrációnál leválasztott nanogyémánt rétegek 488 nm-es gerjesztéssel mért Raman-spektrumából illesztéssel meghatározott szórási sávok csúcspozíciói $\mathrm{cm}^{-1}$-ben megadva.

\begin{tabular}{|c|c|c|c|c|c|c|}
\hline $\begin{array}{l}\mathrm{CH}_{4} \\
(\%)\end{array}$ & $\begin{array}{l}\text { Gyémánt } \\
\text { csúcs }\end{array}$ & $\begin{array}{c}\text { D-sáv } \\
\text { tartomány }\end{array}$ & $\begin{array}{l}\text { G-sáv } \\
\text { tartomány }\end{array}$ & $\begin{array}{c}v_{1} \\
\text { transz-PA }\end{array}$ & $\begin{array}{c}v_{2} \\
\text { transz-PA }\end{array}$ & $\begin{array}{c}\text { hibás } \mathrm{sp}^{3} \\
\sim 1240\end{array}$ \\
\hline 0,2 & $1332,9 \pm 0,1$ & $1355,1 \pm 12,2$ & $1557,8 \pm 10,8$ & $1114,8 \pm 8,3$ & $1456,7 \pm 15,3$ & $1249,9 \pm 40,7$ \\
\hline 0,5 & $1333,7 \pm 0,1$ & $1350,9 \pm 11,8$ & $1536,7 \pm 2,1$ & $1136,5 \pm 3,5$ & $1464,2 \pm 1,2$ & $1219,1 \pm 4,1$ \\
\hline 1,0 & $1335,4 \pm 0,1$ & $1363 \pm 3,8$ & $1563,1 \pm 2,4$ & $1144,2 \pm 1,8$ & $1481,8 \pm 1,3$ & $1222,8 \pm 2,3$ \\
\hline 1,5 & $1333,3 \pm 0,2$ & $1364,5 \pm 1,1$ & $1552,7 \pm 1,3$ & $1138,7 \pm 0,4$ & $1470,9 \pm 0,5$ & $1225,1 \pm 4,9$ \\
\hline 3,0 & $1334,6 \pm 0,4$ & $1363,7 \pm 0,8$ & $1553 \pm 0,7$ & $1141,5 \pm 0,3$ & $1469,4 \pm 0,3$ & $1216 \pm 2,9$ \\
\hline
\end{tabular}

A hordozóhőmérséklet változtatásának a nanogyémánt réteg kötésszerkezetére gyakorolt hatását a forrásgáz egy közepes metánkoncentrációjánál (1\%) leválasztott mintasoron mutatom be (5.7. ábra (b) része). A Raman-szórási spektrumok a kötésszerkezet mérsékeltebb változását mutatják a leválasztási hőmérséklettel. Emellett a változás tendenciája sem egyirányú. A korábbiakban már ismertetettekhez hasonlóan, ebben az esetben is dekompozícióval határoztam meg a szórási sávok pozícióit és félértékszélességeit, melyeket az 5.2. táblázatban foglalok össze. Ebből jól látható, hogy 
bár kisebb mértékben, de azért a hordozóhőmérséklet változtatása is befolyásolja a gyémánt Ramanszórási csúcsának pozícióját és félértékszélességét. A spektrumok nem gyémánt szerkezetekhez rendelhető szórási sávjait illetően az $\mathrm{sp}^{2}$ kötések szórási intenzitása mérsékeltebb a 700, 750 és $800{ }^{\circ} \mathrm{C}$ on leválasztott rétegeknél. A gyürüs $\mathrm{sp}^{2}$ kötésszerkezet kialakulása jobban érvényesül a $850{ }^{\circ} \mathrm{C}$-on leválasztott mintában, amit az is jelez, hogy a gyürüs szerkezetek lélegző módusának $1368 \mathrm{~cm}^{-1}$-nél jelentkező szórása láthatóan deformálja a gyémánt szórási csúcsát. Mindemellett a nanogyémánt „ujjlenyomat” sávjai 1140 és $1469 \mathrm{~cm}^{-1}$ körül jól megfigyelhetőek. A $970 \mathrm{~cm}^{-1}$-nél jelentkező Si kétfonon szórással már korábban foglalkoztam. E sáv szórási intenzitásának jelentős csökkenése a 850 ${ }^{\circ} \mathrm{C}$-nál készített mintában összhangban van azzal, hogy az $\mathrm{sp}^{2}$ kötésszerkezet Raman-szórása a gyémántéhoz képest jelentősen nő ebben a mintában. Érdemes azonban emellett kiemelni, hogy a hordozóhőmérséklet növelése egészen $800{ }^{\circ} \mathrm{C}$ körüli hőmérsékletekig jó hatással van a nanogyémánt réteg szerkezetére, mivel az ebben a tartományban leválasztott minták esetében az sp ${ }^{2}$ szerkezetekhez rendelhető szórási sávok intenzitása csökken a gyémánt szórási sávjának intenzitásához képest. Azonban a legmagasabb $\left(850^{\circ} \mathrm{C}\right)$ hömérsékleten leválasztott minta esetében a tendencia megszakad. A magasabb hordozóhömérsékletnél tapasztalt jelenség összhangban van a korábbi irodalmi eredményekkel, a magyarázata pedig a hőmérséklet reakciókinetikában okozott változásában keresendő. Magasabb hőmérsékleten a gyémánt felületén lévő lógó kötések az sp ${ }^{2}$ szénszerkezetek kialakulását részesítik előnyben, a hidrogén koncentrációja pedig már nem elegendő, hogy minden $\mathrm{sp}^{2}$ kötést elmarjon, így ezen szerkezetek is a gyémánttal párhuzamosan növekednek [125].

5.2. táblázat $\mathrm{Az}$ 1\% $\mathrm{CH}_{4}$ koncentrációnál és különbözö hordozóhőmérsékleteken leválasztott nanogyémánt rétegek 488 nm-es gerjesztéssel mért Raman-spektrumából illesztéssel meghatározott szórási sávok csúcspozíciói $\mathrm{cm}^{-1}$-ben megadva.

\begin{tabular}{ccccccc}
\hline $\begin{array}{c}\mathrm{T}_{\mathrm{H}} \\
\left({ }^{\circ} \mathrm{C}\right)\end{array}$ & $\begin{array}{c}\text { Gyémánt } \\
\text { csúcs }\end{array}$ & $\begin{array}{c}\text { D-sáv } \\
\text { tartomány }\end{array}$ & $\begin{array}{c}\text { G-sáv } \\
\text { tartomány }\end{array}$ & $\begin{array}{c}v_{1} \\
\text { transz-PA }\end{array}$ & $\begin{array}{c}v_{2} \\
\text { transz-PA }\end{array}$ & $\begin{array}{c}\text { hibás sp }^{3} \\
\text { (t240 }\end{array}$ \\
\hline 650 & $1334,3 \pm 0,2$ & $1366,9 \pm 1,4$ & $1550,6 \pm 2$ & $1137,8 \pm 0,5$ & $1470,3 \pm 0,6$ & $1220,2 \pm 5,3$ \\
700 & $1335,4 \pm 0,2$ & $1362,8 \pm 2,4$ & $1557 \pm 1,6$ & $1144 \pm 2,3$ & $14675 \pm 1$ & $1223,5 \pm 2,6$ \\
750 & $1335,4 \pm 0,1$ & $1363 \pm 3,8$ & $1563,1 \pm 2,4$ & $1144,2 \pm 1,8$ & $1481,8 \pm 1,3$ & $1222,8 \pm 2,3$ \\
800 & $1335,5 \pm 0,1$ & $1369 \pm 3,8$ & $1563,9 \pm 2,7$ & $1140,7 \pm 1,4$ & $1477,1 \pm 1,6$ & $1225,2 \pm 21,4$ \\
850 & $1333,5 \pm 0,2$ & $1368,4 \pm 1,4$ & $1555 \pm 0,7$ & $1140,6 \pm 0,6$ & $1469,3 \pm 0,6$ & $1224,4 \pm 8,4$ \\
\hline
\end{tabular}

A Raman-szórási spektrumok igazolják, a gyémánt kialakulását az MW CVD folyamatban és a leválasztott nanogyémánt rétegek kötésszerkezetének változását a forrásgáz metánkoncentrációjával. Amint később majd látni fogjuk a SEM képek analízisénél, mindez szoros kapcsolatban van a nanogyémánt vékonyréteg textúrájának, a gyémánt szemcsék méretének a változásával. 


\subsubsection{Pásztázó elektronmikroszkópia nanogyémánt vékonyrétegeken}

Amint azt már a korábbiakban részleteztem, nanogyémánt vékonyrétegek szisztematikus sorozatát állítottuk elő a forrásgáz metántartalmának, valamint a hordozó hőmérsékletének, mint leválasztási paramétereknek a változtatásával. A vékonyrétegek textúrájának, morfológiai jellemzőinek monitorozása pásztázó elektronmikroszkópiával (SEM) történt. A vizsgálatokat együttmüködés keretében végeztük az MTA Müszaki Fizikai és Anyagtudományi Kutatóintézetben. A SEM képeket egy Leo 1540XB fókuszált ionnyalábú berendezés segítségével rögzítettük. Valamennyi vékonyrétegről készült SEM felvétel különböző nagyításokkal, most azonban csak néhányat mutatok be, amelyek jól reprezentálják az adott paraméterek függvényében a textúra és morfológia változását.

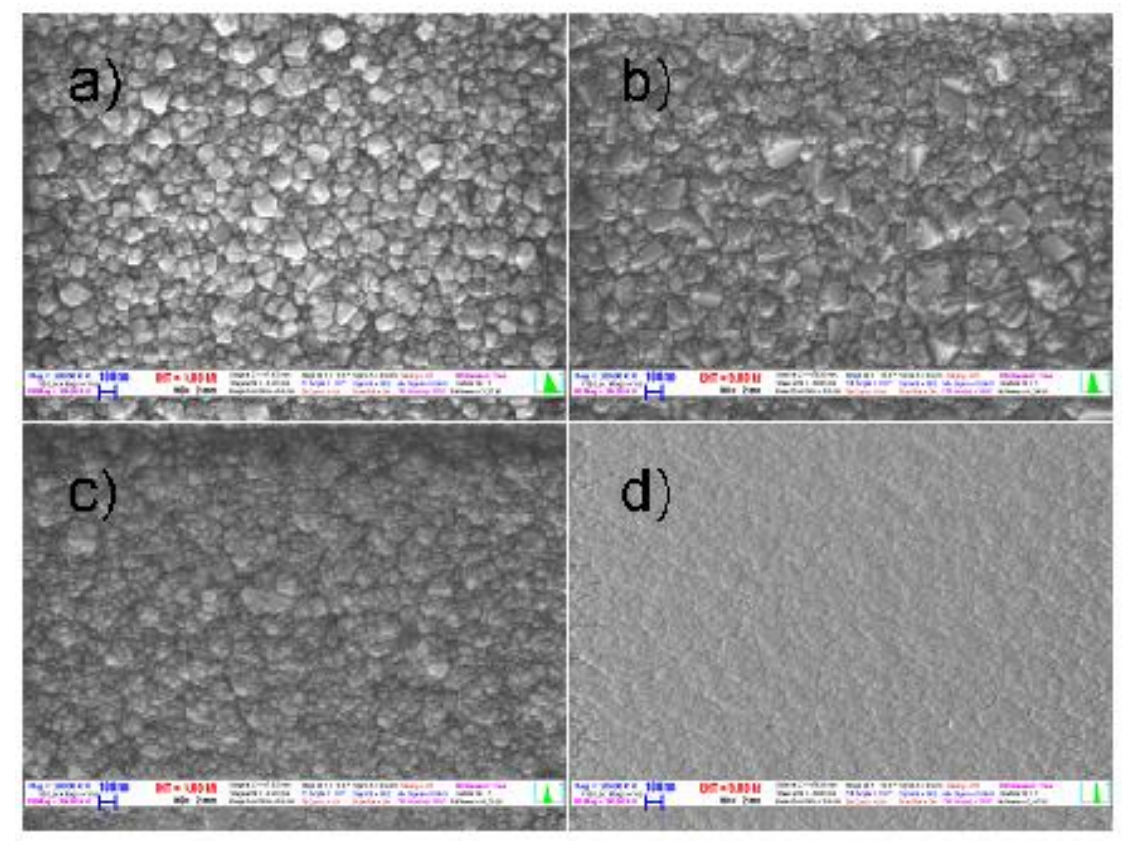

5.8. ábra: $M W C V D$ módszerrel $650^{\circ}$ C hordozóhömérsékletnél leválasztott nanokristályos gyémánt vékonyrétegek pásztázó elektronmikroszkópos felvétele a forrásgáz különbözö $\mathrm{CH}_{4}$ tartalma mellett:

$$
\text { (a) } 0,2 \% \text {; (b) } 0,5 \% \text {; (c) } 1,0 \% \text {; (d) } 2,0 \% \text {. }
$$

$\mathrm{Az}$ 5.8. ábrán a $650{ }^{\circ} \mathrm{C}$ hordozó hőmérsékletnél és a forrásgáz $0,2 \%, 0,5 \%, 1 \%$ és $2 \%$ metánkoncentrációnál leválasztott nanogyémánt vékonyrétegek SEM képei láthatóak. A felvételeken jól látszik, hogy a forrásgáz metántartalma jelentős hatással van a leválasztott vékonyréteg térbeli struktúrájára. A forrásgázban a legkisebb $\mathrm{CH}_{4}$ tartalom mellett leválasztott réteg esetében a legnagyobb a felületen látható kristályszemcsék mérete, de méretük még ebben az esetben sem haladja meg a 150 nm-t. A $\mathrm{CH}_{4}$ koncentráció minimális növelése 0,2\%-ról 0,5\%-ra már jelentős változást okoz a réteg textúrájában. Míg 0,2\%-nál a felületet viszonylag homogén méretü és jól kivehető formájú kristályok borítják, addig a $0,5 \%$ mellett leválasztott rétegen a szemcseméret eloszlást mutat. Az is megfigyelhető, 
hogy míg a kisebb $\mathrm{CH}_{4}$ koncentrációnál az $<110>$ felületek a dominánsak, addig a metán koncentráció növekedése számos nagyobb méretü kristály esetében az $<100>$ felületek megjelenéséhez vezet.

A forrásgáz $\mathrm{CH}_{4}$ koncentrációjának további növelése 1,0\%-ra a szemcsék határainak összeolvadását okozza. A réteg egyes részein összenőtt ikerkristályok is láthatók, melyek növekedési irányát nehéz meghatározni. További sajátosság, hogy a legtöbb nagyobb kristályon számos kisebb méretü kristály látható, ami a másodlagos nukleáció folyamatára utal.

$2 \% \mathrm{CH}_{4}$ koncentráció mellett a réteg karfiolszerü karaktert vesz fel. Apró, közel azonos méretü szemcsék borítják a felületet. Az alacsonyabb metánkoncentrációnál korábban tapasztalt jól megkülönböztethető kristályfelületek teljes hiánya jellemzi a mintát.

Az 5.9. ábrán a forrásgáz $1,0 \% \mathrm{CH}_{4}$ tartalma mellett, de különböző hordozó hőmérsékleteknél leválasztott nanogyémánt vékonyrétegek SEM felvételeit mutatom be. Alacsonyabb hordozó hömérsékleten $\left(650^{\circ} \mathrm{C}\right)$, a réteg felülete túlnyomórészt karfiolszerü szerkezetet mutat, valamint néhány ikerkristály is megtalálható, melyek felülete sűrűn borított néhány nanométer átmérőjü kristálykákkal. Hasonlóan a nagy $\mathrm{CH}_{4}$ koncentráció mellett leválasztott mintákhoz, a kristályfelületek meghatározása szinte lehetetlen.

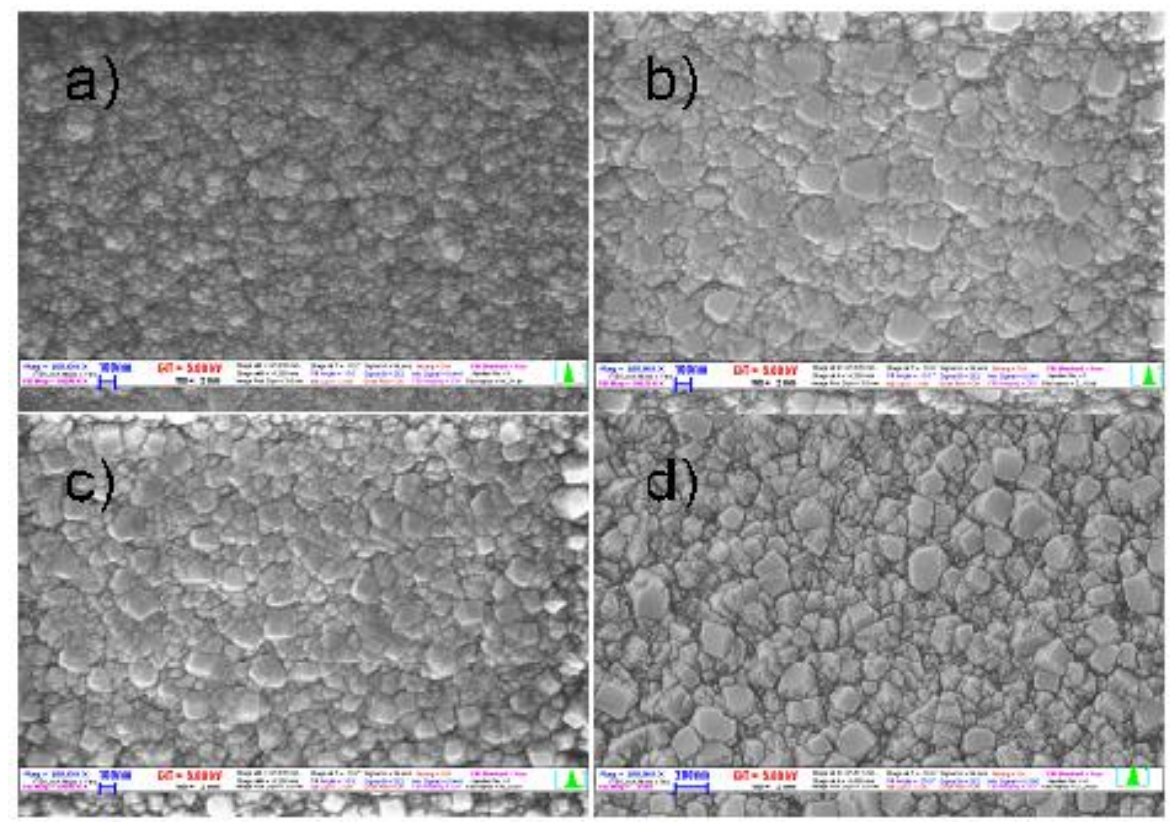

5.9. ábra: $M W$ CVD módszerrel a forrásgáz 1,0\% CH4 tartalma mellett, különbözö hordozó hömérsékleten leválasztott nanokristályos gyémánt vékonyrétegek pásztázó elektronmikroszkópos felvétele: (a) $650{ }^{\circ} \mathrm{C}$; (b) $700{ }^{\circ} \mathrm{C}$; (c) $750{ }^{\circ} \mathrm{C}$; (d) $800^{\circ} \mathrm{C}$.

A hordozóhőmérsékletnek 650 -ről $700{ }^{\circ} \mathrm{C}$-ra történő emelése az $<100>$ felületek megjelenését eredményezi a rétegben. A jellemzően nagy átmérővel rendelkező kristálykák mellett még továbbra is előfordulnak ikerkristályok, valamint részben jelen van a karfiolos szerkezet. A hordozóhőmérséklet további emelése $750{ }^{\circ} \mathrm{C}$-ra az $<100>$ felületü, nagyméretü kristálykák számának látványos csökkenését 
okozza. Emellett a rétegben megjelennek az $<110>$ felületü kristálykák, azonban továbbra is az <100> felület a domináns. Ennek ellenére, a szemcseméret sokkal homogénebb eloszlást mutat, mint a 700 ${ }^{\circ} \mathrm{C}$-on leválasztott mintánál.

A $800{ }^{\circ} \mathrm{C}$-on leválasztott rétegben folytatódik az $<110>$ felülettel rendelkező kristálykák számának növekedése. A réteg sokkal strukturáltabbá válik az alacsonyabb hőmérsékleten leválasztottakhoz képest, azonban a szemcseméret nem mutat olyan homogén eloszlást, mint a $650{ }^{\circ} \mathrm{C}$ on és $0,2 \% \mathrm{CH}_{4}$ koncentrációnál leválasztott mintánál (lásd 5.8. ábra (a) képe).

A SEM felvételek lehetőséget adnak arra, hogy a nanogyémánt vékonyrétegek morfológiáját az átlagos szemcseméret megadásával jellemezzük. A szemcseméret meghatározására két módszert alkalmaztunk. Az első módszer során az ImageJ [126] ingyenes JAVA alapú számítógépes szoftvert használtuk, melyet széles körben alkalmaznak képfájlok feldolgozására és analizálására. A program funkciói többek között lehetővé teszik a felhasználó által kijelölt terület pixelértékekben történő meghatározását, illetve a megfelelő kalibrálás után a geometriai méretek megjelenítését, melyekből később akár különböző statisztikákat tudunk meghatározni. A program gyengéje, hogy szemcseméret meghatározás során nagyon kritikus a készített SEM felvétel minősége, illetve a kontrasztbeállítás befolyásolhatja a kapott értékeket. Ezzel a problémával én is szembesültem, mikor a nagyon finom szemcsével borított karfiolszerü rétegeket, illetve néhány „sötét” felvételt analizáltam. Ezeknél az eseteknél a szoftver irreális értékeket határozott meg az átlagos szemcseméretre. A program által meghatározott szemcseméretek kontrollálása érdekében egy egyszerü, ám elég pontos statisztikai eljárást alkalmaztam.

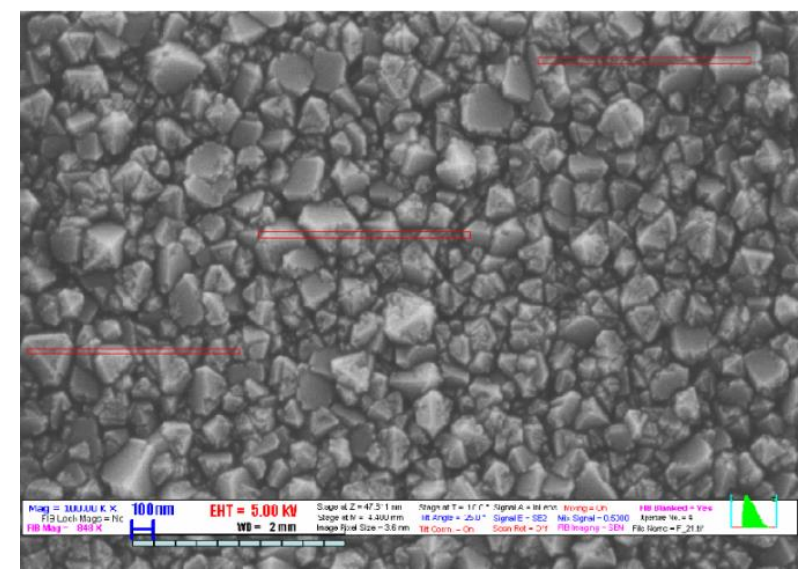

5.10. ábra: A nanogyémánt vékonyrétegek átlagos szemcseméretének meghatározására alkalmazott statisztikus módszer illusztrálása a $850^{\circ} \mathrm{C}$-on és $0,5 \% \mathrm{CH}_{4}$ koncentráció mellett leválasztott mintán.

A módszer lényege, hogy a készített képeken eredetileg feltüntetett skála alapján 1 mikrométer (az eredeti SEM képen feltüntetett szakasz tízszerese) hosszú vonalat szerkesztettem minden egyes minta 3 különböző területére (jobb felső, középső és bal alsó sarok) (5.10 ábra). Ezt követően meghatároztam, hogy hány szemcsén haladnak keresztül az egyes vonalak, majd a vonal hosszúságát 
elosztottam a szemcsék számával, így megkapva az adott terület átlagos szemcseméretét. A három különböző érték átlaga pedig az adott réteg átlagos szemcseméretét adta (12.2. függelék).

$\mathrm{Az}$ 5.11. ábrán látható az átlagos szemcseméret változása a nanogyémánt vékonyrétegekben a forrásgáz metántartalmának és a hordozó hőmérsékletének, mint leválasztási paramétereknek a függvényében. Mivel az átlagos szemcseméret viszonylag nagy hibával határozható csak meg (lásd a 12.2. függeléket), ezért elsősorban a változás tendenciáját érdemes vizsgálni. Nézzük meg először a forrásgáz metántartalmának hatását a réteg morfológiájára. Az 5.11.(a) ábra alapján azt mondhatjuk, hogy a réteg átlagos szemcsemérete fokozatosan csökken, amint a forrásgáz metánkoncentrációja 0,2\%-ról 3\%-ra nő. A változás a legnagyobb a $850{ }^{\circ} \mathrm{C}$ hordozó hőmérsékleten leválasztott mintasorozaton, amely esetben 150 nm-ről 50 nm alá csökken. A szemcseméret csökkenése a legkisebb a $650{ }^{\circ} \mathrm{C}$ hordozó hőmérsékleten készült vékonyrétegekben. A változás $\sim 50 \mathrm{~nm}$, amint a forrásgáz $\mathrm{CH}_{4}$ tartalma 0,2\%-ról 2\%-ra nő. A 750 és $800{ }^{\circ} \mathrm{C}$-on leválasztott mintákban az átlagos szemcseméretnek kissé nagy a fluktuációja az 1-2\% metántartalomnál. A szemcseméret változása a kis metánkoncentrációk tartományában 1-1,5\%-ig meredekebb, majd a göbék ellaposodnak és közelítőleg telítésbe mennek. Ez szépen tükrözi a rétegnövekedés mechanizmusának változását. Az első szakaszban ugyanis a rétegépítés sebességét a plazmában rendelkezésre álló szabad gyökök mennyisége, míg a második szakaszban, amikor a nagy metánkoncentráció folyamatosan biztosítja a plazmában a rétegnövekedéshez rendelkezésre álló gyököket, a növekedési sebességet a szabad helyek száma korlátozza. Ez azt is jelenti, hogy az első szakaszban lehetőség van a nagyobb méretü nanogyémánt kristálykák növesztésére, míg a második szakaszban jelentősen lecsökken a kristálykák mérete és a legnagyobb metánkoncentrációknál már alig változik az átlagos szemcseméret.

Érdemes ezek után megnézni, hogy a forrásgáz egy adott metántartalma mellett milyen hatással van az átlagos szemcseméretre a hordozó hőmérsékletének változtatása. A hőmérséklet általában a folyamat kinetikájára van hatással, így a magasabb hordozóhőmérséklet segíti a felületi kötések relaxációját, gyorsítja a struktúra rendeződését, elősegítve ezáltal a réteg növekedését. Alacsonyabb hőmérsékleteken ezek a folyamatok lassabban mennek végbe, így a gyémánt kristálykák növekedése is kisebb mértékü. Természetesen ezektől a tendenciáktól és az adott növekedési mechanizmustól is függ a hordozó hőmérsékletének a hatása. A $0,2 \%, 0,5 \%$ és $1 \% \mathrm{CH}_{4}$ koncentrációknál a vizsgált hordozó hőmérséklettartományban nagyon hasonló a változás tendenciája. A $650{ }^{\circ} \mathrm{C}$ alacsony hömérséklet a kristálykák növekedésére, ezért egy ugrásszerü szemcseméret növekedés tapasztalható, amint a hordozó hőmérsékletét $700{ }^{\circ} \mathrm{C}$-ra növeljük. A szemcsék mérete alig változik, ha a hőmérsékletet $800{ }^{\circ} \mathrm{C}$-ra emeljük. Egy újabb jelentős szemcseméret növekedés tapasztalható a hordozó hőmérsékletének $850^{\circ} \mathrm{C}$-ra történő emelésekor. Ez azt jelenti, hogy ilyen metánkoncentrációk mellett 700-800 ${ }^{\circ} \mathrm{C}$-on lehet növeszteni gyémánt kristályokat, de az ideális hőmérséklet $850{ }^{\circ} \mathrm{C}$. Nagyobb 
metánkoncentrációknál, amelyeknél már a növekedés mechanizmusa is változik, a hordozó hömérséklet növelésének elönyös hatása kevésbé tud érvényesülni, ezért az átlagos szemcseméret változása a $750{ }^{\circ} \mathrm{C}$ és $850{ }^{\circ} \mathrm{C}$ hőmérsékletek között nem mutat egyértelmű tendenciát.
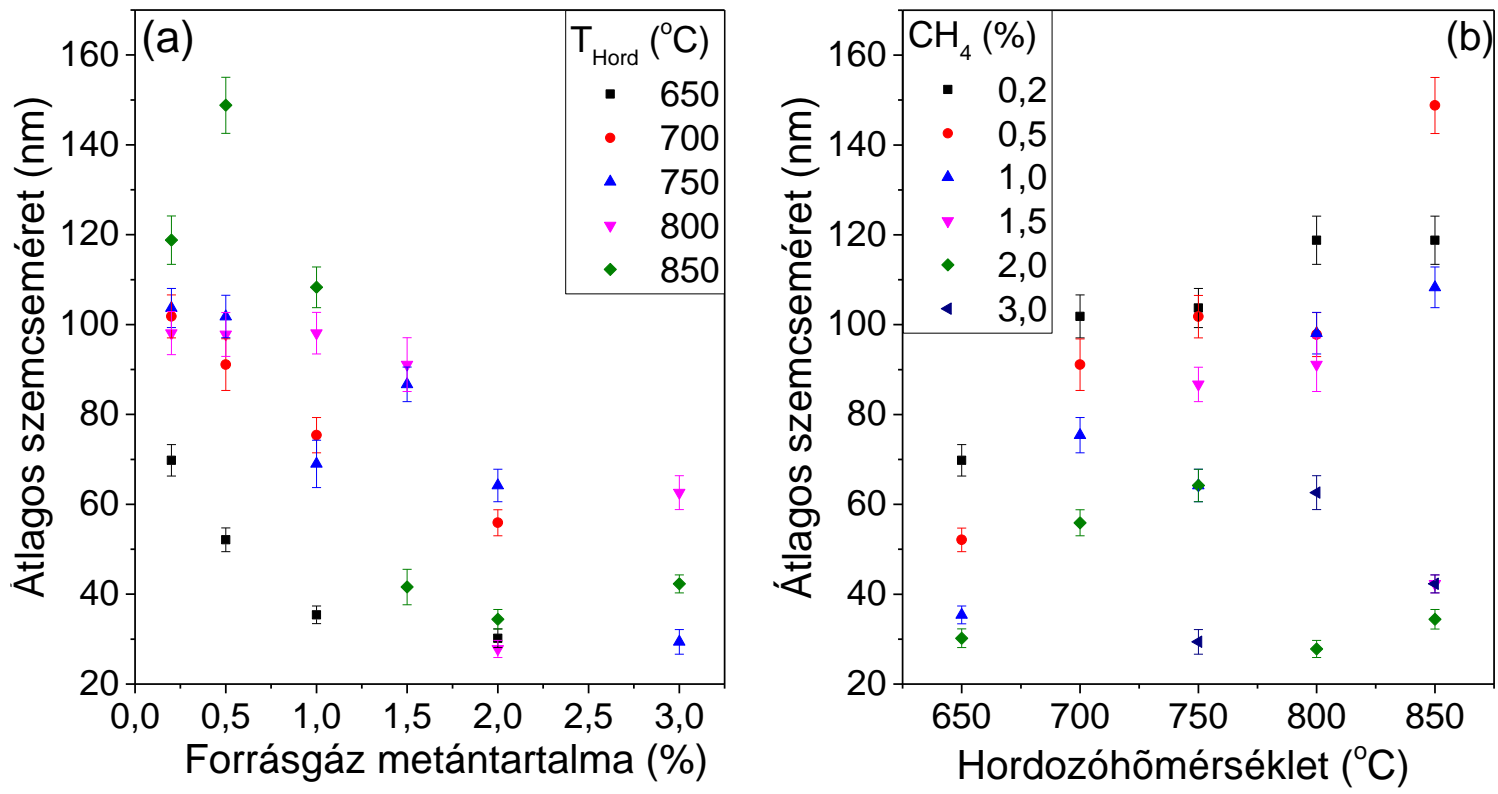

5.11. ábra: A nanogyémánt vékonyrétegek átlagos szemcseméretének változása (a) a forrásgáz $\mathrm{CH}_{4}$ koncentrációjának és (b) a hordozó hömérsékletének függvényében.

Összeségében a SEM képek vizsgálata alapján megállapítható, hogy a forrásgáz metántartalma és a hordozó hőmérséklete egyaránt hatással van a növesztett rétegek textúrájára és morfológiájára. A tapasztalt változások összhangban vannak a nanogyémánt vékonyrétegek Raman-szórási spektrumaiból kapott eredményekkel.

\subsection{Fotolumineszcencia vizsgálatok}

A lumineszcenciának, mint vizsgálati módszernek, előnyös tulajdonsága a nagy érzékenysége. Jól analizálható jelet már $\sim 10^{14}$ centrum $/ \mathrm{cm}^{3}$ sürüségnél mérhetünk. Ezzel függ össze, hogy már kicsi gerjesztő intenzitások mellett is információt kaphatunk a különböző optikai átmenetekről, a vizsgálandó anyag károsodása nélkül. Ezek az optikai átmenetek a vizsgált anyag elektronszerkezetével kapcsolatos elektronátmeneteket és ezen átmeneteknél fellépö kölcsönhatásokat jellemzik. A fotolumineszcencia vizsgálati módszer különösen előnyös külső szennyezésekkel, valamint kristályhibákkal kapcsolatos optikai centrumok tanulmányozására.

A lumineszcencia vizsgálatok fizikai hátterei, melyek hatékonnyá teszik ezt a módszert a gyémántban található optikailag aktív hibahelyek vizsgálatára: a gyémántkristály magas Debye hőmérséklete, amely a könnyü szénatomok közötti erős kovalens kötéssel függ össze és a centrumoknál fellépő viszonylag gyenge elektron-fonon kölcsönhatás. A felsorolt tulajdonságoknak köszönhetően a 
gyémántban található optikailag aktív hibahelyek többsége karakterisztikus zérusfonon emisszióval és a hozzá tartozó rezgési oldalsávval rendelkezik szobahőmérsékleten, vagy akár afölött is. Minthogy a zérusfonon vonal és a hozzá kapcsolódó rezgési oldalsáv a centrumra jellemző, így a fotolumineszcencia nem csak a centrumok karakterizálására, hanem azok beazonosítására is jól használható.

\subsubsection{Emissziós spektroszkópia}

Az emissziós spektroszkópia széles körben alkalmazott módszer a gyémántszerkezetekben található optikailag aktív hibahelyek feltérképezésére és beazonosítására. A vizsgálat során a mintát egy adott hullámhosszú (energiájú) fénynyalábbal világítják meg és detektálják a gerjesztés hatására a minta által emittált fény hullámhossz szerinti eloszlását.

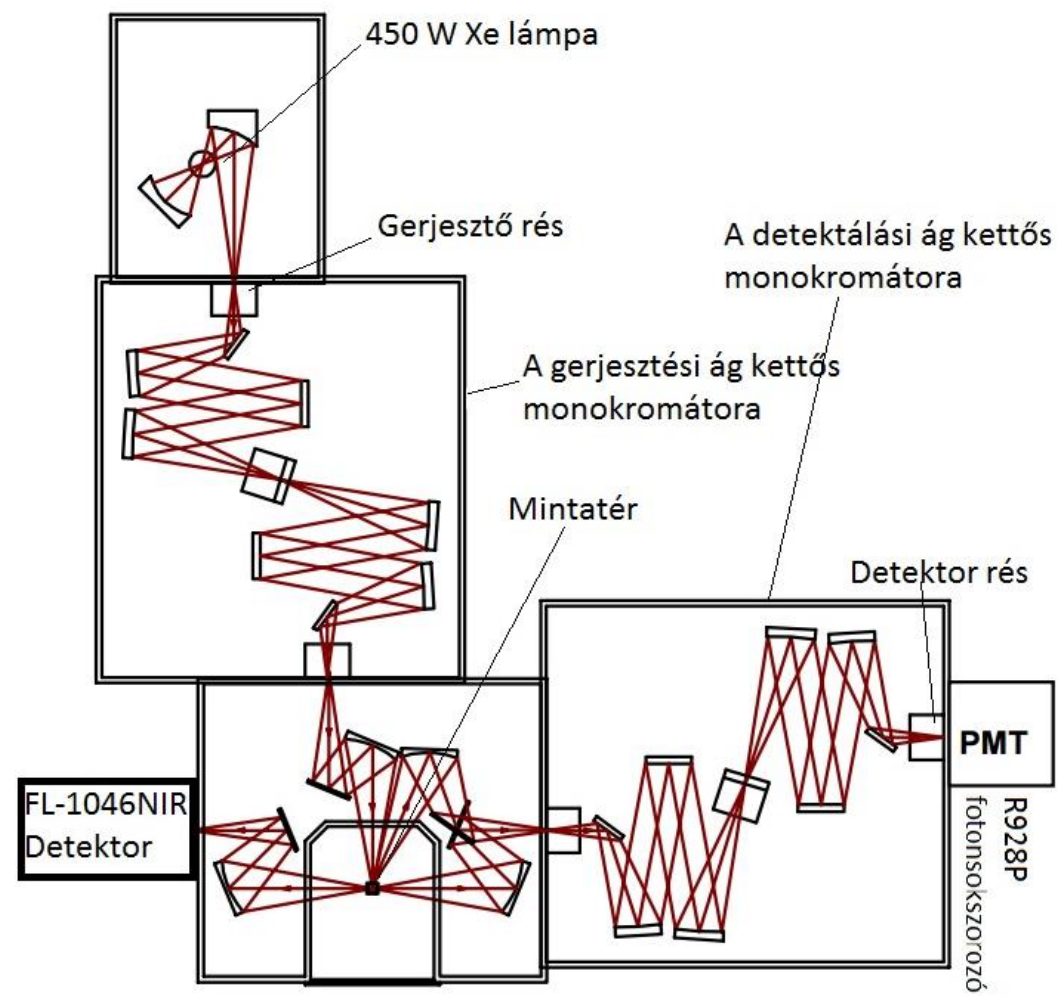

5.12. ábra: A Horiba Jobin Yvon FL3-221 típusú spektrométer elvi rajza.

Az emissziós spektrumok mérésére két különböző készüléket használtam. A mélykékben emittáló N3 centrumot tartalmazó mintákat egy Horiba Jobin Yvon FL3-221 típusú spektrométer segítségével vizsgáltam. A méréseket szoba- és alacsony hőmérsékleten végeztem reflexiós geometriában. A készülékben található kettős monokromátor, melyben a rácsok mozgatása léptetőmotorral történik, lehetővé teszi az emisszió széles tartományon belüli vizsgálatát (250-1500 $\mathrm{nm})$, valamint a gerjesztő hullámhossz precíz kiválasztását. Gerjesztő fényforrásként egy $450 \mathrm{~W}$ teljesítményü magasnyomású Xe lámpa szolgál, de lehetőség van külső, akár lézerfény használatára is. 
Mind a gerjesztési, mind pedig a detektálási oldalon változtatható a spektrális résszélesség 0,1-20 nm között. Az adott emissziós spektrumokhoz tartozó feloldóképességet az ábrákon fogom feltüntetni. A jel/zaj viszony javítása érdekében változtatható az integrálási idő, illetve a lépésköz. Továbbá, lehetőség van a spektrumok felvételének automatikus ismétlésére és szoftveres összeadására. Az emissziós spektrumok minél precízebb meghatározása céljából változtatható a detektálási lépésköz. A készülékbe 2 detektor került beépítésre, az egyik egy R928P foton sokszorozó, mely 250-900 nm között teszi lehetővé az emisszió detektálását, míg a másik egy cseppfolyós nitrogénnel hüthető FL-1046NIR félvezető fotodióda, amely 850-1500 nm között használható. A készülék automatikusan korrigálja a mért spektrumokat a gerjesztő fény intenzitás eloszlására, a spektrométer átviteli függvényére, valamint a detektor érzékenységének hullámhossz függésére. A készülék elvi rajza az 5.12. ábrán látható.

Az emissziós spektrumok felvételét 1,65-4,25 eV (750-290 nm) tartományban végeztem különböző gerjesztések mellet. Az ábrákon megadom, hogy a spektrumot milyen gerjesztő energia mellett mértem. A minél monokromatikusabb gerjesztés érdekében a gerjesztő monokromátoron keskeny kilépő rést ( $2 \mathrm{~nm}$ ) használtam. A kiértékelés során a spektrumokat a maximális intenzitásra, mint egységre normáltam. Egyes méréseknél a gerjesztő vonal másodrendjének kiszürése érdekében Oriel gyártmányú W302, GG13, B221 típusú vágószürőket használtam.

A $S i V$ centrum emissziós tulajdonságainak vizsgálata során a méréseket döntően mikroszkóp alatt végeztem a Raman-méréseknél már részletezett Renishaw 1000 típusú spektrométer segítségével. A mérések során 100x nagyítású objektívet használtam. A fotolumineszcencia és Raman-spektrumok felvétele minden egyes minta esetében egyidejűleg, ugyanazon gerjesztett térfogatból történt, a Ramanspektrumok felvételénél is használt mérési paraméterek mellett. A gerjesztéshez a legtöbb esetben egy Spectra-Physics Stabilite 2017 típusú Ar ion lézer 488 (2,54 eV) nm-es vonalát használtam, továbbá végeztem méréseket különböző diódalézerek $405 \mathrm{~nm}(3,06 \mathrm{eV}), 532 \mathrm{~nm}(2,33 \mathrm{eV})$ és $635 \mathrm{~nm}(1,95$ eV) használatával is.

\subsubsection{Gerjesztési spektroszkópia}

Az előzőekben részletezett emissziós spektroszkópia mellett az optikailag aktív centrumok vizsgálatának ugyancsak elterjedt módszere az abszorpciós spektroszkópia. Ez a módszer azonban valamennyi hibahelytől származó abszorpciót méri az adott fotonenergiánál. Éppen ezért, ha egy adott optikai centrum (amely egyben lumineszcencia centrum is) abszorpcióját szeretnénk vizsgálni, akkor a gerjesztési spektroszkópia módszerét célszerủ alkalmazni. A gerjesztési spektrum felvételekor az adott centrum emissziós intenzitásának változását vizsgáljuk a gerjesztő fotonenergia függvényében. A módszer előnye az abszorpciós spektroszkópiával szemben, hogy itt csak a ténylegesen emissziót 
okozó optikai átmeneteket detektáljuk. Itt érdemes megjegyezni azonban, hogy a centrumon belüli, tehát rezonáns gerjesztéshez tartozó elektronátmenetek mellett lehetséges nagyobb fotonenergiájú gerjesztése is a centrumnak, pl. rezonáns energiatranszfer révén.

Kísérleteink során a lumineszcencia gerjesztési spektrumokat az emissziós spektrumok felvételére is alkalmazott Horiba Jobin Yvon FL3-221 típusú spektrométerrel rögzítettem. A készülék 450 W Xe lámpája lehetővé teszi a különböző emissziós centrumok gerjesztési tulajdonságainak széles tartományban történő (250-900 nm (4,959-1,378 eV)) vizsgálatát. Ebben a mérési összeállításban a gerjesztési spektrumot különböző emissziós hullámhosszaknál lehet vizsgálni, azonban a legcélszerübb az emissziós spektrum csúcspozíciójának az emissziós monokromátor résszélessége által meghatározott spektrális tartományában mérni. A spektrumok felvétele során az emissziós intenzitás függvényében különböző spektrális résszélességeket alkalmaztam. A méréseket minden esetben ún. front-face geometriában végeztem. Míg az N3 centrumot tartalmazó minták esetében a lumineszcencia gerjesztési spektrumok vizsgálata 4,95-2,75 eV fotonenergia-tartományban történt, addig a $\mathrm{SiV}$ centrum gerjesztési tulajdonságait 3,1-1,67 eV fotonenergia-tartományon belül analizáltam.

\subsubsection{Alacsony hőmérsékletü mérések}

Az emisszió ZPL-jének spektrális pozícióját elsősorban a megfelelő optikailag aktív hibahely atomi szerkezete határozza meg. Az optikai centrum elektron átmenetével kölcsönhatásban lévő kvázilokális és/vagy lokális rezgések energiái kizárólag a megfelelő defektus atomi szerkezetével vannak összefüggésben. Azonban tudnunk kell, hogy a centrum a gyémánt mátrixba van ágyazva, tehát a csúcspozíció és a lokális, kvázi-lokális rezgési energia a gyémánt mátrix egyedi jellemzője. Abból a célból, hogy a gyémánt fonon energiáinál kisebb $(<70 \mathrm{meV})$ energiájú lokális és kvázi-lokális rezgésekről minél több információt gyüjtsünk, lumineszcencia méréseket végeztünk alacsony hőmérsékleten $(\sim 8 \mathrm{~K})$. Az alacsony hőmérsékletű mérések során egyaránt vizsgáltuk az N3 és a $\mathrm{SiV}$ centrumok emissziós és gerjesztési spektrumait. A mérési paraméterek megegyeztek a szobahőmérsékleten végzett mérésekével. A minták $8 \mathrm{~K}$ hőmérsékletre való lehütését egy zárt ciklusú, hélium hütőközegü Air Products kriosztát segítségével végeztem. A mérések során a kriosztát választható ablakai közül a látható tartományban jó transzmissziós tulajdonságokkal rendelkező, kvarcból készült ablakokat használtam. A kriosztát mintatartóját a lehütés előtt $2 \times 10^{-5}$ mbar vákuumra szívtam le. A mintatartót mechanikai $x, y$ és $z$ tengelyü pozicionálók és egy rezgésmentesített állvány segítségével pozícionáltam a fluorológ készülék mintaterében. A mérések minden esetben front-face geometriában történtek. 


\section{Eredmények és diszkussziójuk}

A kutatási célkitüzéseimnek megfelelően $N 3$ és $S i V$ optikai centrumokat alakítottam ki nanogyémántban az adott szennyező atomoknak a gyémánt kristályrácsába történő beépítésével. Lumineszcencia spektroszkópiai módszerrel igazoltam az említett két centrum kialakulását és meghatároztam azok spektroszkópiai jellemzőit. Az elvégzett kutatások eredményeit és azok diszkusszióját két alfejezetben ismertetem.

Az első alfejezetben detonációs módszerrel készült, $\sim 12 \mathrm{~nm}$ átlagos szemcsemérettel rendelkező nanokristályokban kialakított N3 optikai centrumokkal foglalkozom. A második alfejezetben mutatom be az MW CVD módszerrel előállított nanogyémánt rétegekben kialakított $\mathrm{SiV}$ centrumokra vonatkozó eredményeimet.

\subsection{Az $N 3$ centrum}

Ebben az alrészben először bemutatom a kezeletlen nanogyémánt lumineszcencia spektrumát, majd ezután foglalkozom a PIII módszerrel, 20 és $30 \mathrm{keV}$ ionenergiákkal implantált nanogyémánt lumineszcenciájával, majd a $750{ }^{\circ} \mathrm{C}$-on és azt követően $450{ }^{\circ} \mathrm{C}$-on végrehajtott hőkezeléseknek a lumineszcencia spektrumra gyakorolt hatását tárgyalom. Ezt követően az implantálás és a hőkezelések által okozott kötésszerkezeti változások analízise következik. Hasonló módon történik a FIB módszerrel, $2 \mathrm{keV}$ ionenergiáknál végrehajtott implantáció hatásának a bemutatása is. Az implantációval és hőkezelésekkel kialakított új lumineszcencia sáv spektrális jellemzőinek analízise következik ezután. Végül a 8 K-en mért emissziós és gerjesztési spektrumokat ismertetem, amelyek további kísérleti eredményekkel támasztják alá az N3 centrum kialakítását.

\subsubsection{A kezeletlen nanogyémánt szemcsék fotolumineszcenciája}

Abból kiindulva, hogy a lumineszcencia spektroszkópiát használtam a nanogyémántban kialakítandó $N 3$ optikai centrum beazonosítására és jellemzésére, fontos tudni, hogy az eredeti minta milyen lumineszcencia spektrummal jellemezhető. A különböző módon előállított nanogyémánt kristályok széles fotonenergia-tartományt átfogó lumineszcencia spektrummal rendelkeznek, egyrészt a rácshibáknak, másrészt a keletkezésük során beépült különböző szennyező atomoknak köszönhetően. Ez jellemző a robbantással előállított nanogyémánt kristályokra is [127]. Annak érdekében, hogy a nanogyémánt szemcsékben lévő hibahelyekhez, szennyezésekhez köthető emissziós szerkezeteket minél szélesebb tartományban vizsgálhassuk, érdemes nagy energiájú gerjesztést alkalmazni. A 6.1. ábrán a kísérleteinkhez használt nanogyémánt porból készített nanogyémánt „réteg” fotolumineszcencia spektruma látható, amit 4,59 eV $(270 \mathrm{~nm})$ fotonenergiával gerjesztettünk. 


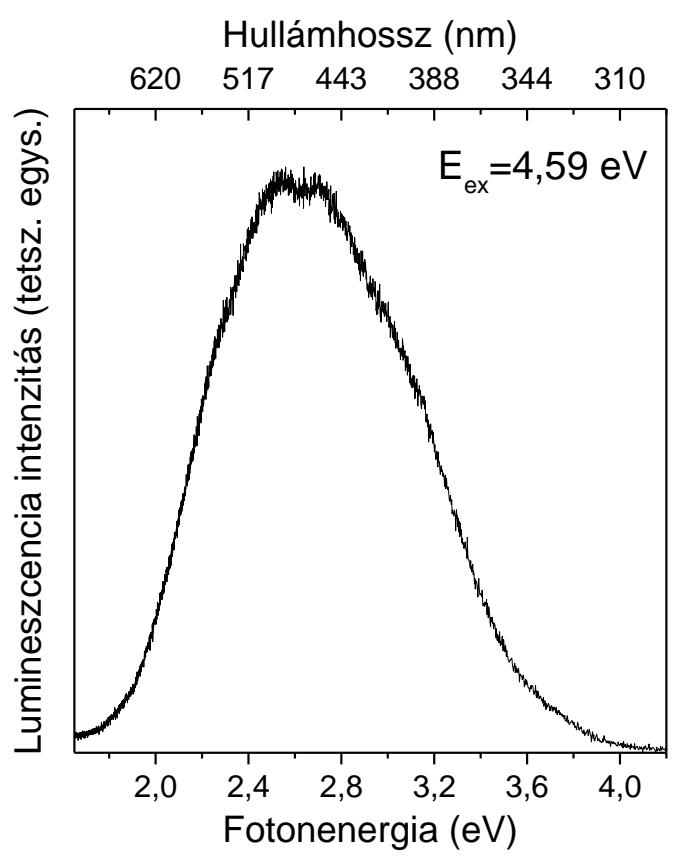

6.1. ábra: Az N3 optikai centrum kialakitására használt, 12 nm átlagos szemcseméretü nanogyémánt fotolumineszcencia spektruma szobahömérsékleten.

Az emissziós spektrum széles, némileg aszimmetrikus eloszlást mutat 1,8-3,8 eV fotonenergiák között, mely tipikusnak nevezhető az azonos módszerrel előállított és hasonló kristálymérettel rendelkező nanogyémántok esetében $[104,128]$. A szobahőmérsékleten mért spektrum nem tartalmaz intenzív, keskeny sávot, ami esetleg valamely ismert, akár nitrogénhez, vagy más szennyezőhöz köthető, optikailag aktív hibahelyhez lenne rendelhető. A két legintenzívebb emissziós csúcs 2,54 és 2,7 eV környékén található. Ezen kívül két nehezen beazonosítható vállszerkezet figyelhető meg a spektrumban 2,3 és 3,1 eV környékén. Mivel a detonáció gyorsan lezajló folyamat, ezért a detonációs nanogyémánt tartalmaz(hat) szerkezeti kristályhibákat, valamint a nem tökéletes tisztítási eljárás miatt felületi szennyezőket. A nanogyémánt mintánkon tapasztalt lumineszcencia forrásai egyaránt lehetnek a szerkezetben található, optikailag aktív hibahelyek és a felületen található szennyezések. Mivel jellemzően az utóbbihoz köthető emisszió intenzitása jelentősen kisebb, mint a színcentrumoké, ezért valószínűsíthető, hogy a mintánkban tapasztalt emisszió különböző szerkezeti hibákhoz köthető [129, 130]. A sávok nagy félértékszélessége és átlapolása pedig a szerkezeti hibákkal és az emissziós centrumok eltérő környezetével magyarázható. A 3,1 eV környékén jelentkező váll a mesterséges gyémántban az N-sávként (N-band) azonosított hibahelyhez rendelhető, mely gyakran megfigyelhetö a CVD módszerrel növesztett gyémánt rétegekben. Az N-sáv hibahely szerkezetét tekintve feltehetően egy szubsztitúciós nitrogén atomból áll $[58,131]$. Ami az emisszió kisenergiájú oldalán jelentkező gyengén kifejezett vállat illeti, nagy valószínüséggel az ún. zöld emissziós sávnak tulajdonítható. A 2,3 eV környékén jelentkező zöld emisszió eredetét számos cikkben diszkutálják, de nincs elfogadott 
értelmezése. A nanogyémánt nagy fajlagos felülete miatt a felületet lezáró nem gyémánt kötések, mint hibahelyek elfogadható magyarázatát adják ennek a sávnak.

Az emissziós spektrum két legintenzívebb csúcsának hibahely szerkezethez való rendelése már némileg bonyolultabb, mivel ebben a tartományban több olyan centrum is emittál, melyek okozhatják az egymással átlapoló, széles emissziós sávokat. Míg a nagyobb energiánál $(2,7 \mathrm{eV})$ jelentkező emisszió forrása nagy valószínűséggel intersticiális nitrogénhez köthető hibahely [89, 1], addig a kisebb energiánál jelentkező sáv forrása egyaránt lehet intrinszik hibahely, vagy felületi szennyezés is. Ezért aztán a 2,54 eV körül látható emissziós sáv forrása vagy az N-V-N szerkezetü, nitrogénhez köthető hibahely, amely a természetes gyémántokban plasztikai deformáció által alakítható ki [132, 1], vagy a felületre kötött különböző karbokszil csoportok [130].

\subsubsection{PIII módszerrel implantált nanogyémánt}

A gyémánt szerkezetekben utólagosan hibahelyeket kialakítani leghatékonyabban ion implantációval, vagy más, kisméretü részecskével történő besugárzással lehet. Sokszor azonban az implantálni kívánt különböző részecskék felgyorsítása a megfelelő kinetikus energiára összetett és költséges berendezéseket igényel. Nem beszélve arról, hogy a leggyakrabban használt nagy ionenergiák alkalmazása jelentősen roncsolja a kristályszerkezetet, amely folyamat akár visszafordíthatatlanul a szerkezet teljes elpusztításához vezethet. Fokozottan igaz ez a nanogyémánt kristályok esetében, ahol a kristályméret miatt a szerkezet teljes roncsolása sokkal inkább valószínúbb, mint a tömbi kristálynál. Ezek a tényezők inspiráltak, hogy a detonációs nanogyémánt minták esetében olyan technikát használjak, ami kis ionenergiáknál is jól müködik és szélesebb körben elérhető a laboratóriumokban, így esett a választás a plazmaimmerziós ionimplantáció módszerre, melynek eredményeit az alábbiakban ismertetem.

\subsubsection{Fotolumineszcencia spektrumok}

A PIII módszerrel implantált nanogyémánt tulajdonságaiban az alkalmazott kezelések hatására bekövetkezett változásokat fotolumineszcencia spektroszkópiával követtem nyomon. Az előző részben már analizáltam az implantációs kísérletekhez használt detonációs nanogyémánt lumineszcencia spektrumát, ezért a továbbiakban erre nem térek ki részletesen, azonban a kezelésekkel okozott változások szemléltetése érdekében a nem kezelt nanogyémánt spektrumát is bemutatom az egyes ábrákon. A vizsgált fotonenergia-tartományon belül meghatározott spektrumalakok összevethetősége érdekében az egységre normált spektrumokat ábrázolom, a normálás minden esetben a maximális intenzitásra történt. 


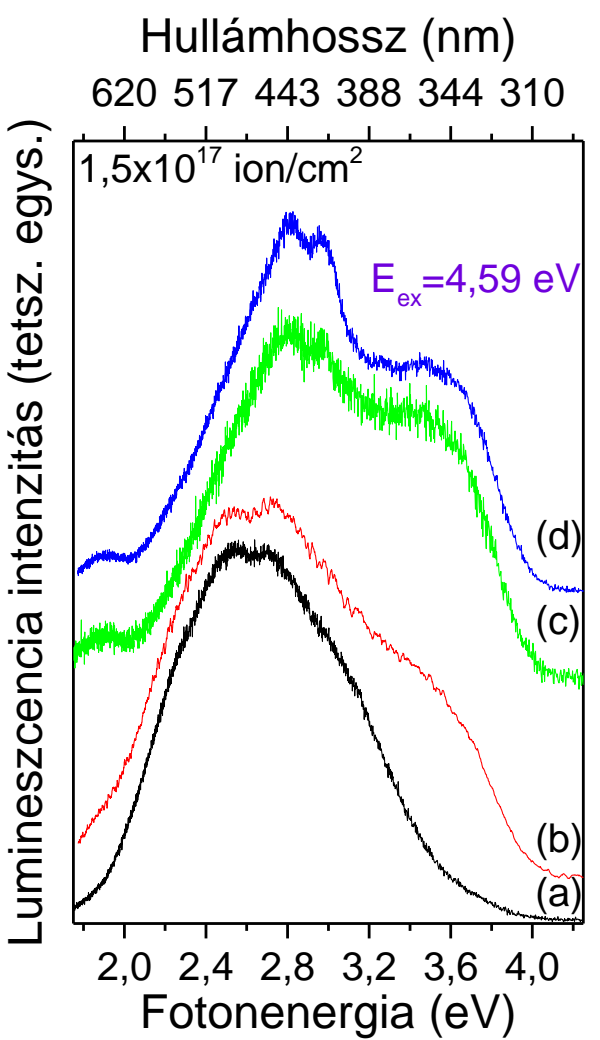

6.2. ábra: A PIII technikát használva 30 keV ionenergiával és különbözö típusú ionokkal végzett implantálás hatása a nanogyémánt minta lumineszcencia spektrumára: (a) nem kezelt minta, (b) He ${ }^{+}$ és $\mathrm{N}_{2}^{+}$ionokkal implantált minta, (c) $\mathrm{He}^{+}$ionokkal implantált minta, (d) $\mathrm{N}_{2}^{+}$ionokkal implantált minta.

A 6.2. ábra szemlélteti a PIII technikával, $30 \mathrm{keV}$ ionenergiával végzett $\mathrm{He}^{+}$és $\mathrm{N}_{2}^{+}$ionok implantációjának hatását a nanogyémánt fotolumineszcencia spektrumára. Az alapelgondolás, mely szerint keskeny emissziós sávval rendelkező lumineszcencia centrumot alakítunk ki a mintákban egy komplex technológia révén, melynek során $\mathrm{He}^{+}$besugárzással szénvakanciákat hozunk létre, majd implantáljuk a nitrogént, első ránézésre nem hozta a várt eredményt a $30 \mathrm{keV}$-os ionenergiák alkalmazása során. Bár a 4,59 eV fotonenergiával gerjesztett emissziós spektrumokon jól látszik, hogy a különböző ionokkal implantált minták spektrumai jelentősen különböznek, azonban a színcentrumokra általában jellemző, jól megkülönböztethető, keskeny emissziós sáv nem detektálható egyik esetben sem. A keskeny emissziós sáv hiánya azonban egyáltalán nem jelenti azt, hogy hatástalan volt az implantáció, ugyanis a megfelelő szerkezetű hibahelyek kialakítása nem egyszerü folyamat. Főleg nem az N3 optikai centrum esetében, amelynél három nitrogén atomnak és egy vakancia hibahelynek kell egy adott szerkezeti környezetben találkoznia. Hasonlóan más kísérleti megfigyelésekhez várható, hogy a komplex centrum utókezelések hatására fejlődik csak ki [133]. Ennek ellenére érdemes megvizsgálni, hogy az egyes implantált szennyezések milyen változásokat eredményeznek a nem implantált nanogyémánt spektrumában. Mindez hozzájárul ahhoz, hogy 
megértsük a hibahelyek kialakulását a nanogyémánt szerkezetekben utólagos ionimplantáció alkalmazása során.

A spektrumokon jól látható, hogy az implantált ionok fajtájától függetlenül az emissziós spektrum minden esetben kiszélesedett a nem implantált mintáéhoz képest. Míg a csak nitrogén (6.2.(d) ábra), vagy csak héliumionokkal (6.2.(c) ábra) történő bombázás alkalmazása közel azonos emissziós komponensek kialakulását eredményezi a spektrum kisenergiájú oldalán található emissziós sáv relatív intenzitásának csökkenése mellet, addig a két ionnal történő együttes (6.2.(b)) bombázást követően a legszélesebb eloszlású emissziós spektrumot kapjuk. Emellett valamennyi implantált nanogyémánt minta fotolumineszcencia spektrumának közös tulajdonsága a nagy energiájú oldalon, 3,5 eV körül megjelenő széles emissziós váll. Ez a váll kevésbé hangsúlyos a héliummal és nitrogénnel is implantált nanogyémántban. A széles fotonenergia-tartományt átfogó, nagyenergiáknál megjelenő sáv több hibahely-együttes jelenlétéhez rendelhető, melyek emissziós vonalai átlapolnak egymással. Többek között a széles lumineszcencia sáv egyik komponense $\sim 3,6$ eV-nál diszlokációkhoz rendelhető. A tömbi gyémántban 3,65 eV-nál detektált elektronátmenetet, mely a vezetési sávból történik a diszlokációk által kialakított, a vegyértéksáv maximumától 1,75 eV-ra található nívókra az említett rácshibahely típussal magyarázták [133]. A nagyenergiájú emissziónak az implantáció által kialakított szerkezeti rácshibákhoz való rendelését az is alátámasztja, hogy az függetlenül az implantált ion típusától, minden esetben megjelenik a spektrumokban. Megalapozottnak tűnik az egyes elméleti megfontolásokban vizsgált, különböző térbeli szerkezettel és elektromos töltéssel rendelkező szénvakancia struktúrákhoz $\left(\mathrm{V}, \mathrm{V}_{2}\right)$ és szubsztitúciós nitrogénhez $\left(\mathrm{N}_{\mathrm{s}}\right)$ rendelni az implantáció hatására keletkező széles emissziós sávot, mivel ezen szerkezetek sávjai a számolások alapján ebbe a tartományba esnek [134].

A fentiekben részletezett emissziós sávon kívül a csak nitrogénnel implantált minta esetében egy dupla csúcsú emissziós szerkezet jelenik meg a spektrumban, mely a csak héliummal történő implantáció során is megfigyelhető, azonban utóbbi esetben kevésbé hangsúlyos. A 2,97 és 2,81 eV körül detektálható csúcsok a természetes kristályból jól ismert $N 3$ centrumhoz rendelhetőek, mivel a nagyobb energiáknál található sáv közel esik az említett hibahely 2,985 eV-nál jelentkező ZPL-jéhez, míg a kisebb energiáknál jelentkező a ZPL-hez tartozó fonon oldalsávhoz köthető. Mivel az emissziós sáv a $\mathrm{He}^{+}$implantációnál is megjelenik, joggal feltételezhető, hogy a kiindulási anyagunk tartalmaz nitrogén szennyezőket, azonban ezen szennyezők nem képeznek lumineszcencia centrumot, ahogyan azt a nanogyémánt por emissziós spektrumának analízise során is láthattuk. A detonációs módszerrel készült nanogyémántban kismértékben jelen lévő nitrogén szennyezést mások is detektáltak [132]. Ennek magyarázata, hogy a robbantás során nagy mennyiségű nitrogén forrás (TNT és hexogén) található a detonációs kamrában, melynek egy része beépül a szerkezetbe. Emellett vegyük figyelembe, 
hogy a csak $\mathrm{He}^{+}$ionokkal implantált minta lumineszcencia spektruma rossz jel/zaj viszonnyal rendelkezik, ami arra utal, hogy a mintában csak elenyésző számú centrum alakulhatott ki, így további nitrogének bevitele feltétlenül szükséges a centrum hatékony kialakításához. Továbbá, a nitrogénszennyezők bevitele kedvezőbb körülményeket teremt a nitrogén-vakancia komplex centrumok kialakulásához, mivel a nitrogénionok az implantálás során azonos mélységi tartományban alakítanak ki vakanciákat a szerkezetben, ahogyan ezt a SRIM szimulációkból is jól láthattuk.

Némileg különös lehet, hogy az $\mathrm{N}_{2}^{+}$és $H e^{+}$ionok együttes alkalmazása nem eredményezi az N3 emissziós szerkezet további erősödését a spektrumban, mint ahogy az várható lenne, bár tény, hogy az említett tartományban a minta emissziója relatíve intenzív. A tapasztalt változások lehetséges magyarázata, hogy ezen ionokkal történő besugárzás egymás után, kvázi kétszeres ionsürüséggel történt, melynek következtében a nanogyémánt felületek nagyobb mértékben sérültek, mint az egyfajta ionnal kezelt minták esetében. Az ionoknak a szerkezetben való fékeződése a szénatomok közötti kötés felszakításával járhat, aminek következtében elsősorban a felületen (mivel itt a legnagyobb az ionok energiája) $\mathrm{sp}^{2}$ hibridizációjú szénatomokat tartalmazó szerkezetek alakulhatnak ki. Ezek a kötések a gyémánt tilos sávjában hoznak létre lokalizált állapotokat, amelyek önabszorpció révén csökkentik az emittált lumineszcencia intenzitást, de természetesen emissziós centrumként is szerepelhetnek. Az sp ${ }^{2}$ szerkezet kialakulásával kapcsolatos feltételezéseket a Raman-spektroszkópiával végzett kötésszerkezeti vizsgálatok is megerősítették, melyekről részletesebben a 6.1.2.3. részben lesz majd szó.

A 6.2. ábrán bemutatott kísérleti eredmények és azok analízise arra enged következtetni, hogy az implantált ionok típusa és mennyisége is hatással van a nanogyémánt minta lumineszcencia tulajdonságaira. Ezért egy másik kísérletsorozat során azt vizsgáltam, hogy az ionsürüség változtatása milyen hatással van a nanogyémánt minta fotolumineszcencia spektrumára. Ennek érdekében a nitrogénnel történő implantálás során $1,5 \times, 3,0 \times, 4,5 \times 10^{15}$ ion $/ \mathrm{cm}^{2}$ ionsürüséget használtunk, míg a héliummal történő implantálást állandó, $1,8 \times 10^{15} \mathrm{ion} / \mathrm{cm}^{2}$ mellett végeztük. Mivel a célunk nitrogénhez köthető lumineszcencia centrumok utólagos kialakítása detonációs módszerrel előállított nanogyémántban a lehető legkisebb energiák alkalmazásával, ezért ezen kísérleteinkben az implantált ionok energiáját $20 \mathrm{keV-re} \mathrm{csökkentettük.} \mathrm{A} \mathrm{választott} \mathrm{ionenergia} \mathrm{hatékonyságát} \mathrm{a} \mathrm{korábban} \mathrm{elvégzett}$ SRIM kalkulációk is alátámasztják (SRIM rész). Továbbá, az előző kísérletekben megfigyeltek alapján, ahol a csak nitrogénionokkal történő implantálás hatékonyabbnak bizonyult (karakteresebb és relatíve intenzívebb nitrogén centrumhoz köthető emissziós sáv a 6.2. ábrán) a csak hélium implantációval szemben, ezért ebben a kísérletben csak a nitrogén, illetve a hélium- és nitrogénionok együttes hatását vizsgáltam. 
Hullámhossz (nm)

620517443388344310

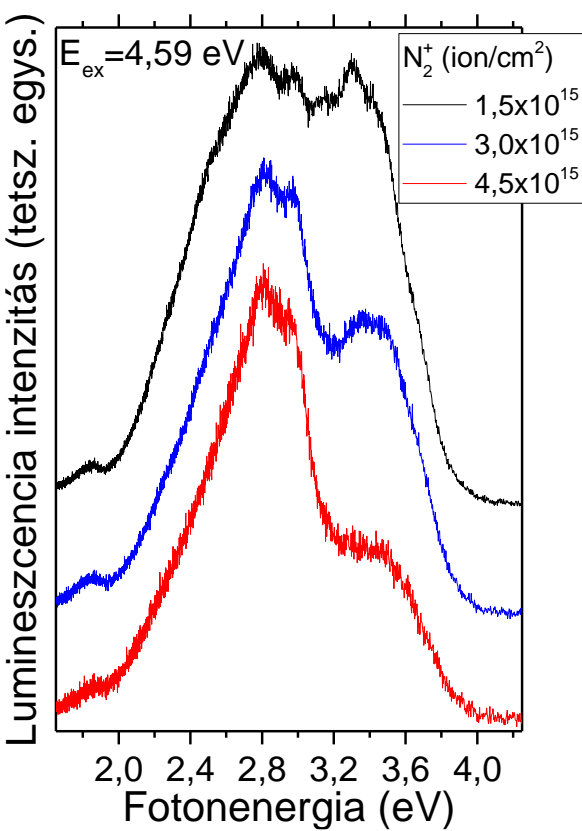

6.3. ábra: Az implantált $N_{2}^{+}$ionfluxus változtatásának hatása a nanogyémánt lumineszcencia spektrumára 20 keV energiájú ionokkal történő implantálás esetében.

A 6.3. ábrán a $20 \mathrm{keV}$ ionenergiával végzett $N_{2}^{+}$ionimplantáció hatása látható, mely 3 különböző iondózis alkalmazása mellett történt. A lumineszcencia spektrumban bekövetkezett változások jól mutatják, hogy a nitrogénionok számának növelésével a spektrumot egyre inkább az N3 lumineszcencia centrumhoz rendelhető emissziós sáv dominálja. A kisebb iondózis alkalmazása a már korábban említett nagyenergiájú tartományban eredményez egymással átlapoló emissziós sávokat 3,13,8 eV fotonenergiák között, melyek egyszerübb szerkezeti hibák kialakulására, valamint a nitrogén szubsztitúciós helyre való beépülésére engednek következtetni. Az $N_{2}^{+}$ionok számának növelése az ionnyalábban egyértelmúen a komplexebb szerkezettel rendelkező, több nitrogén atomot tartalmazó centrumhoz köthető emisszió $(2,81-2,97 \mathrm{eV})$ relatív intenzitásának növekedéséhez vezet a spektrumban. A tapasztalt változás lehetséges magyarázata, hogy a kisebb számú nitrogénionnal történő implantálás során a gyémánt szerkezetben kialakulnak szénvakanciák, melyeket a nitrogénionok a kristályban megtett trajektóriájuk során a rácshelyeken elhelyezkedő szénatomok „,kiütésével” alakítanak ki, miközben fokozatosan elveszítik energiájukat. Emellett a nitrogénionok egy része szubsztitúciós helyre épül be, azonban nem tud hatékonyan komplex szerkezettel rendelkező centrumot kialakítani, mivel nincs a közvetlen szomszédságában több nitrogén és/vagy szénvakancia. Az implantált nitrogénionok számának a növelése mind a vakanciák, mind pedig a beépülő nitrogének mennyiségének a növekedéséhez vezet, aminek következtében a komplex nitrogénhez köthető centrumok kialakulásának a valószínüsége is megnő, amit a lumineszcencia spektrumok változása is 
jól tükröz (6.3. ábra). A komplex nitrogén centrumra utaló emissziós sávok mellett a spektrumban továbbra is megtalálható a 3,5eV-nál jelentkező széles sáv, ami arra utal, hogy a kialakított szerkezeti hibáknak (vakanciák) csak egy része vesz részt a komplex nitrogén centrum kialakításában. Ezt az implantált ionok és a keltett hibahelyek mélységeloszlásának a SRIM kalkulációja is mutatja. Az ionok viszonylag széles mélységi eloszlásban alakítanak ki hibahelyeket, valamint implantálódnak és ezen tartományok nem teljesen fedik át egymást (5.1.1.3. rész).

\section{Hullámhossz (nm)}

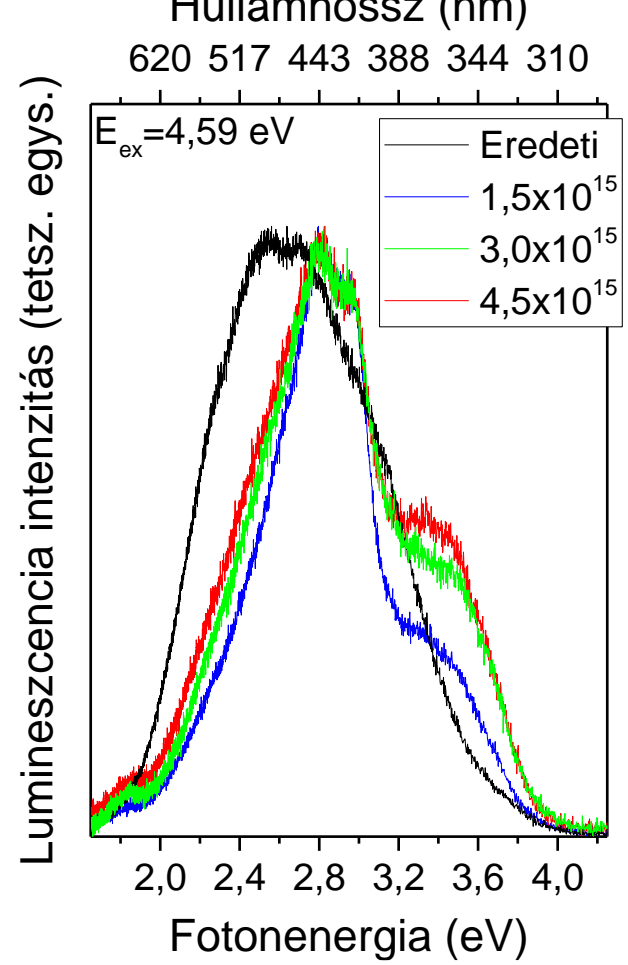

6.4. ábra: $1,8 \times 10^{15}$ ion $/ \mathrm{cm}^{2}$ fluxusú $\mathrm{He}^{+}$és az ábrán feltüntetett 3 különbözö fluxusú $\mathrm{N}_{2}^{+}$ ionnyalábokkal implantált nanogyémánt minták lumineszcencia spektrumai.

Az előzőekben leírt kísérletek eredményeinek az értelmezése során, amikor csak $N_{2}^{+}$ionokkal implantáltuk a mintáinkat, láthattuk, hogy a nitrogénionok fluxusának növelése a komplex nitrogén centrumhoz köthető emissziós sáv relatív intenzitásának növekedéséhez vezet a lumineszcencia spektrumban. Azonban azt is láthattuk, hogy ezen komplex centrumok hatékony kialakításához szénvakanciákra és lokálisan több nitrogénatomra van szükség. Tény, hogy a nitrogén implantálás is létrehoz hibahelyeket, ám ezek nem mindig találhatóak azonos mélységben a beépült nitrogén atomokkal, így logikusan merül fel az ötlet, hogy vizsgáljuk meg a komplex nitrogén centrumok kialakulását az emissziós spektroszkópia alkalmazásával olyan mintákban, amelyekben már előzőleg kialakítottunk vakanciákat. Ebből a célból az előbbiekben alkalmazott nitrogén fluxusoknak megfelelő ionnyalábbal implantáltuk azokat a mintákat, melyeket előzőleg $1,8 \times 10^{15}$ ion/ $/ \mathrm{cm}^{2} \mathrm{He}^{+}$bombázásnak 
tettünk ki. A $\mathrm{He}^{+}$ionok kis méretüknek köszönhetően kevésbé roncsolják a szerkezetet, azonban az alkalmazott ionenergiák mellett hatékonyan képeznek szénvakanciákat a gyémántszerkezetben.

A 6.4. ábrán az $1,8 \times 10^{15}$ ion $/ \mathrm{cm}^{2}$ fluxusú $\mathrm{He}^{+}$ionnyalábbal történő bombázást követő, különböző fluxusú $N_{2}^{+}$ionokkal végzett ionimplantációnak a lumineszcencia spektrumra gyakorolt hatása látható. Ellentétben az előző kísérletsorozattal, ahol csak nitrogénnel implantáltuk a nanogyémántot, az ezt megelőzően $H e^{+}$ionnyalábbal végrehajtott implantáció kedvező hatással van a 2,97 és 2,81 eV fotonenergiáknál megjelenő emissziós sávok kialakulására. Az említett két sáv minden esetben dominálja a spektrumot, azonban a dózis növelésével az emissziós sáv némileg kiszélesedik a spektrum kisenergiájú oldalán. Ez feltehetően azzal van kapcsolatban, hogy a szerkezetbe juttatott nitrogének egyre növekvő mennyisége lehetővé teszi egyre komplexebb szerkezettel rendelkező centrumok kialakulását. Ilyen például a 2,64 eV fotonenergiánál emittáló $N 4$ centrum, mely könnyen okozhatja a spektrumokon megfigyelhető intenzitásnövekedést a kisenergiájú oldalon [44]. A 3,5 eVnál jelentkező széles emissziós komponens relatív intenzitása az iondózis növelésével növekszik, ami nincs összhangban azon eredményekkel, amelyeket a csak $N_{2}^{+}$ionnyalábbal történő bombázásnál a fluxus növelésekor tapasztaltunk (lásd 6.3. ábra). Ez a látszólagos ellentmondás feloldható, ha figyelembe vesszük, hogy egy implantált nanogyémánt szerkezetbe juttatjuk be az $N_{2}^{+}$ionokat, továbbá, hogy a $\mathrm{He}^{+}$ionnyaláb legalább 2,5-szer akkora mélységben hoz létre vakanciákat és intersticiális szénatomokat, mint amilyen mélységbe az $N_{2}^{+}$ionok bejutnak. Az $N_{2}^{+}$iondózis növekedése növekvő mértékben okozza a már hibás gyémánt szerkezetben újabb vakanciák és intersticiális szénatomok kialakulását, ami növelheti a $\sim 3,5$ eV-os sáv relatív lumineszcencia intenzitást. Másként fogalmazva ez azt jelenti, hogy egy bizonyos ionkoncentráció felett a szerkezetben kialakított vakanciák már fölösleget képeznek, mivel a bejuttatott nitrogének centrumképzése során, azok limitált száma miatt, a vakanciák egy része nem tud részt venni a komplex hibahelyszerkezetek kialakulásában.

PIII módszert alkalmazva $\mathrm{N}_{2}^{+}$és $H e^{+}$ionokat implantáltam $\sim 12 \mathrm{~nm}$ átlagos szemcseméretü nanogyémántba. Megmutattam, hogy 20 és $30 \mathrm{keV}$ ionenergiákkal $1,5-4,5 \times 10^{15} \mathrm{ion} / \mathrm{cm}^{2}\left(N_{2}^{+}\right)$és $1,8 \times 10^{15}\left(\mathrm{He}^{+}\right)$ionfluxusok alkalmazásával a mélykék és ultraibolya hullámhosszaknál emittáló komplex lumineszcencia centrumot és intrinszik hibahelyeket lehet kialakítani $\sim 12$ nm-es nanogyémánt kristályokban. A lumineszcencia spektroszkópia alkalmazásával kísérletileg igazoltam, hogy $\mathrm{He}^{+}$implantálásával már $1,5 \times 10^{15} \mathrm{ion} / \mathrm{cm}^{2}$ ionfluxussal is hatékonyan alakítható ki nitrogénnel kapcsolatos komplex hibahely centrum, amely 2,98 eV-nál emittál, ugyanakkor a nitrogén ionfluxus növelése már kedvez a 3,5 eV-nál emittáló intrinszik hibahelyek létrejöttének. A várakozásoknak megfelelően csak $N_{2}^{+}$ionokkal végzett implantálásnál a nagyobb ionfluxusok kedveznek a 2,98 eV-nál 
emittáló komplex szennyezési centrum képződésének, ugyanis ezen implantációnál már az $N_{2}^{+}$ionok hozzák létre a centrum kialakulásához szükséges szénvakanciákat is. A kizárólag $H e^{+}$ionokkal implantált minta esetében a kis intenzitású, mélykék emissziós sáv kialakulása az előállítási technológiájával összefüggő, kismértékű nitrogén szennyezettségével magyarázható.

\subsubsection{A hőkezelések hatása a fotolumineszcencia spektrumra}

Az előző részben bemutattam, hogy a PIII implantáció már mérsékelt ionenergiák mellett is alkalmas komplex szennyezési centrum és intrinszik hibahelyek kialakítására nanogyémántban. A lumineszcencia spektrumokból (lásd a 6.3. és 6.4. ábrákon) azonban jól látszik, hogy a nitrogénhez köthető komplex szennyezési centrumok emissziója széles fotonenergia-tartományt fed át. Ennek nyilvánvalóan a legfőbb okai az implantáció okozta roncsolódás, a csak részlegesen relaxált gyémánt és színcentrum szerkezetek lehetnek. További problémát okoz, hogy az implantálással kialakított vakanciák csapdázódása a nitrogén szennyező atomoknál csak részben következett be, így a komplex szennyezési centrum szerkezeti elrendeződése nem tudott megvalósulni megfelelő hatékonysággal. Abból a célból, hogy helyreállítsuk a roncsolt gyémánt szerkezetet és elősegítsük minél több komplex szennyezési centrum létrejöttét és relaxációját, az implantált nanogyémántot $1,5 \times 10^{-5} \mathrm{mbar}$ nyomáson, vákuumban $750{ }^{\circ} \mathrm{C}$-on hőkezeltem 2 órán keresztül. Jól ismert, hogy ez a hőmérséklet elegendő a vakancia migráció beindításához és így hozzájárul a kristály- és hibahelyszerkezet relaxációjához, ezáltal pedig a kedvező emissziós tulajdonságok kialakításához is [44].

A vákuumban végzett hőkezelést minden esetben egy 5 órás $450{ }^{\circ} \mathrm{C}$-on történő oxidációs folyamat követte, melyet levegőn végeztem. A második hőkezelés célja az implantációs folyamatok során keletkezett különböző $\mathrm{sp}^{2}$ kötéseket tartalmazó szénszerkezetek eloxidálása volt. Az alkalmazott hőmérséklet hatékonyan csökkenti az $\mathrm{sp}^{2}$ hibridizációjú szénatomok mennyiségét azok eloxidálása által, míg az sp ${ }^{3}$ szerkezetek oxidációja ezen a hőmérsékleten nagyságrendekkel lassabban megy végbe [109].

A 6.5.(a) ábrán a különböző hőmérsékleten és atmoszférában végzett hőkezelések fotolumineszcencia spektrumra gyakorolt hatását mutatom be a $\mathrm{He}^{+}$és $\mathrm{N}_{2}^{+}$ionokkal, $20 \mathrm{keV}$ ionenergia mellett implantált nanogyémánt minta esetében. Jól látható, hogy már a $750{ }^{\circ} \mathrm{C}$-on végzett hőkezelés hatására jelentősen megváltozik az implantált minta emissziós spektruma. A 2,98 és 2,81 eV fotonenergiák körül jelentkező sávok relatív intenzitása megnő, utóbbi egyben a detektált spektrum maximumhelye is. Míg az implantálást követően a két sáv szinte teljesen átlapolt egymással, addig a $750{ }^{\circ} \mathrm{C}$-on végzett hőkezelés hatására jól elkülönülnek. További látványos változás a kisebb energiájú 
oldalon hosszan elnyúló váll intenzitásának jelentős csökkenése, valamint a nagyobb energiáknál jelentkező széles emissziós sáv elkülönülése a 2,98 eV fotonenergiánál található emissziós sávtól.
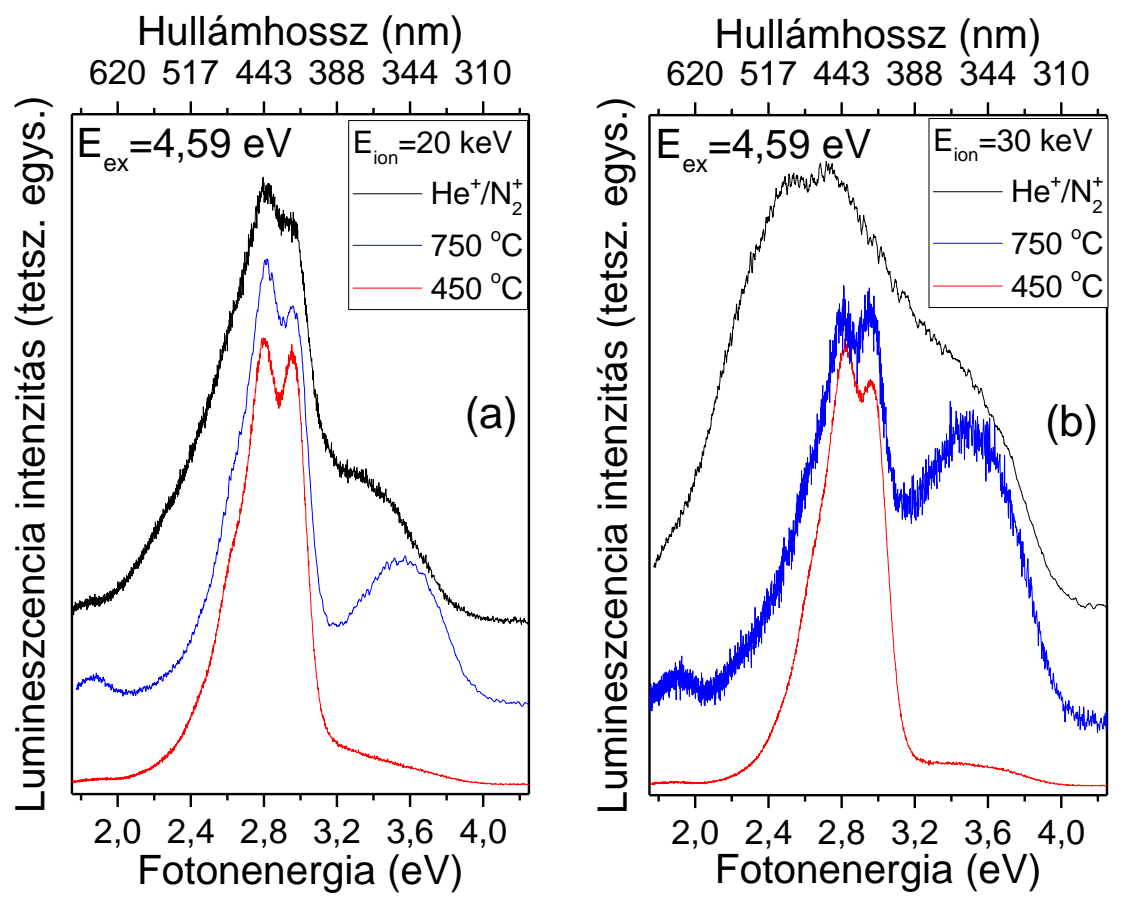

6.5. ábra: A (a) $20 \mathrm{keV}$ és (b) $30 \mathrm{keV}$ ionenergia alkalmazása mellett $\mathrm{He}^{+}$és $\mathrm{N}_{2}^{+}$ionokkal implantált nanogyémánt minta lumineszcencia spektrumai implantálás után, a $750^{\circ} \mathrm{C}$-on nagyvákuumban végzett 2 órás, majd ezután a $450{ }^{\circ} \mathrm{C}$-on atmoszférikus nyomáson végzett hökezeléseket követöen.

$\mathrm{Az} 5$ órás, $450{ }^{\circ} \mathrm{C}$-on levegőn végrehajtott hőkezelés a lumineszcencia spektrum finomszerkezetében 2,98 és 2,81 eV-nál határozott sávok megjelenését eredményezi, további, a spektrum kisenergiájú oldalán vállként jelentkező struktúrákkal együtt. Ugyanakkor a 3,5 eV-nál jelentkező, intrinszik hibákkal összefüggő széles emissziós sáv szinte teljesen eltűnik. Az emissziós spektrum kiszélesedése is csökken, elsősorban a kisenergiájú oldalon jelentkező emisszió gyengülése miatt.

A lumineszcencia spektrumokban tapasztalt változások azt mutatják, hogy az elvégzett hőkezelések egyértelműen az implantációval kialakított finomszerkezettel rendelkező mélykék emissziós sávra hatottak kedvezően. Míg a magasabb hőfokon végzett hőkezelés hozzájárult a lumineszcencia sávért felelős hibahelyszerkezet és környezetének rendeződéséhez, addig az oxidációs folyamat az intrinszik hibák drasztikus csökkenését okozta. Az N3 centrum kialakulása két lehetséges módon mehet végbe a nanogyémántban. Az első, melyet a tömbi kristályban is megfigyeltek, a komplexebb nitrogén ( $B$ centrum) hibahely felbomlása és egy szubsztitúciós helyen lévő nitrogén, valamint szénvakancia közremüködésével való hibahelyszerkezet kialakulása. A másik, mely csak a nagymennyiségü nitrogénionok implantációja során várható, hogy már implantálást követően egymás környezetében lesznek az N3 hibahelyhez szükséges nitrogén atomok és a szénvakancia. Azonban a 
relaxált szerkezettel rendelkező hibahely csak a magas hőmérsékletű hőkezelés hatására alakul ki. A nagyenergiájú széles emissziós sáv intenzitásának csökkenése pedig azzal függhet össze, hogy a levegőn $450{ }^{\circ} \mathrm{C}$-on végzett hőkezelés során a nanogyémánt szemcsékben implantációval kialakított szerkezeti hibák nagy részét eloxidáltuk.

Foglalkozzunk most a $30 \mathrm{keV}$ ionenergiával $1,5 \times 10^{17}$ ion $/ \mathrm{cm}^{2}$ fluxussal implantált nanogyémánt mintákkal. Azt már korábban láttuk (6.2. ábra), hogy ezek az implantálási paraméterek a nanogyémántban jelentős szerkezeti roncsolódást idéznek elő, ami a nanogyémánt lumineszcenciájára is jelentős hatással van. A két lépcsőben végrehajtott hőkezelésnek a nanogyémánt lumineszcencia spektrumára gyakorolt hatását mutatja be a 6.5.(b) ábra. A kiindulási spektrum egy alig strukturált, nagyon széles fotonenergia-tartományt átfogó emisszió. A spektrum alakja drasztikusan megváltozik a $750{ }^{\circ} \mathrm{C}$-on végzett hökezelés hatására, mégpedig egy karakterisztikus struktúra alakul ki, ami a komplex nitrogén szennyezési centrumra jellemző. A spektrum kisenergiájú oldalán jelentősen csökken az emisszió és elkülönül a 3,5 eV-nál jelentkező sáv. Érdemes megjegyezni, hogy romlik a jel/zaj viszony. A $450{ }^{\circ} \mathrm{C}$-on végzett hőkezelés teljesen hasonló eredményre vezetett, mint amit a $20 \mathrm{keV}$ energiájú ionokkal kezelt mintáknál tapasztaltunk. A hőkezelés okozta változások hátterében ugyanazok a relaxációs folyamatok, valamint a vakancia migrációjához kapcsolódó defektcentrum változások állnak, melyeket a fentiekben már részleteztem.

Hullámhossz (nm)

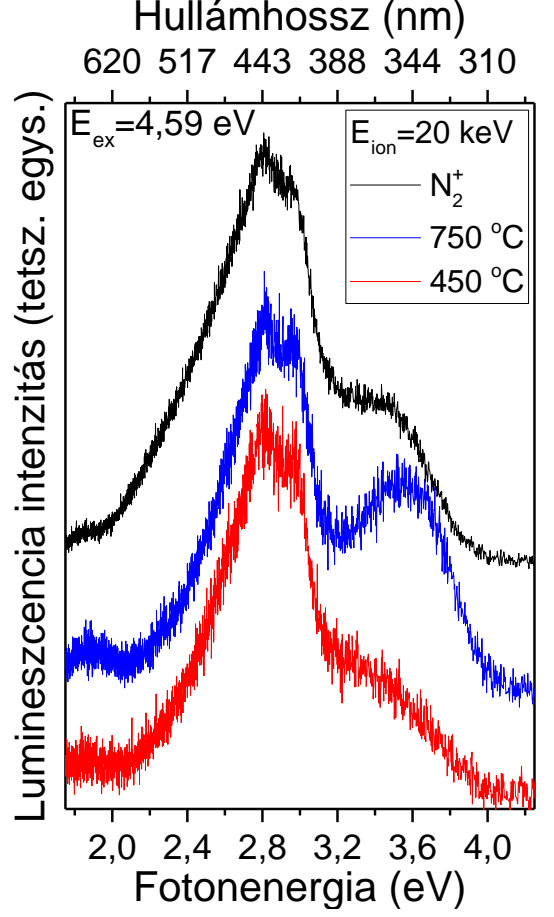

6.6. ábra: A $20 \mathrm{keV}$ ionenergiával és csak $\mathrm{N}_{2}^{+}$ionokkal $\left(1,5 \times 10^{15} \mathrm{ion} / \mathrm{cm}^{2}\right.$ fluxussal) implantált nanogyémánt minta lumineszcencia spektrumának változása a $750{ }^{\circ} \mathrm{C}$-on vákuumban, majd $450{ }^{\circ} \mathrm{C}$ on levegön végzett hökezelések hatására. 
Érdekes megvizsgálni a komplex hőkezelés hatását a lumineszcencia spektrumra azon nanogyémánt mintáknál, amelyek csak nitrogénnel lettek implantálva (6.6. ábra). Mivel a nitrogén implantációja is generál vakanciákat a nanogyémántban, így elvileg adottak a feltételek a komplex nitrogén szennyezési centrumok kialakulására. A $750{ }^{\circ} \mathrm{C}$-os hőkezelés jelentősen csökkentette az implantált minta spektrumának kiszélesedését a kisenergiájú oldalon lévő emissziós sáv intenzitásának csökkenése révén, emellett a 3,5 eV-nál jelentkező emissziós sáv is elkülönül. Ezek a változások összhangban vannak azzal a folyamattal, amelyek során a már kialakult komplex nitrogén szennyezési centrumok környezete relaxál. A spektrumon jól látható jel/zaj viszony romlása viszont arra enged következtetni, hogy az implantálással bevitt nitrogén és a keltett vakanciák nem járulnak hozzá a mélykékben emittáló centrumok képződéséhez. A vakanciák pl. intersticiális szenekkel „annihilálódnak” migrációjuk során. A $450{ }^{\circ} \mathrm{C}$-on végrehajtott oxidáció jelentősen csökkenti az emissziót 3,5 eV-nál, hasonlóan a korábban tapasztaltakhoz.

Összességében a kísérletekből megállapítható, hogy a komplex hőkezelési eljárás jelentős változást eredményez valamennyi implantált minta lumineszcencia spektrumában. $\mathrm{A} 750{ }^{\circ} \mathrm{C}$-on végzett hőkezelés azáltal, hogy termikusan aktiválja a vakancia migrációt, elősegíti a már kialakult szennyezési centrumok környezetének relaxációját, ugyanakkor hozzájárul még több nitrogén atomokat és vakanciát tartalmazó szennyezési centrum kialakulásához. A $450{ }^{\circ} \mathrm{C}$-on végzett hőkezelés elsősorban az $\mathrm{sp}^{2}$ hibridizációjú szénatomok oxidációját segíti elő, csökkentve ezáltal az implantáció okozta szerkezeti roncsolódást és a nanogyémánt felületének amorfizációját. A hőkezelésekkel előidézett szerkezeti változások eredményeként a mélykék hullámhosszaknál intenzív emissziót mutató, komplex nitrogén szennyezési centrumot sikerült kialakítani és jelentősen csökkenteni az intrinszik hibahelyekkel kapcsolatos emissziót a nanogyémánt mintákban. A mélykék emisszió energetikai pozíciójából $(2,98 \mathrm{eV})$ és a kisenergiájú oldalon megfigyelhető strukturáltságból az N3 centrum kialakulására lehet következtetni.

\subsubsection{Az implantálás és hőkezelés okozta kötésszerkezeti változások}

A nagyenergiájú részecskével történő besugárzás a szerkezet roncsolását eredményezi [135]. A roncsolás mértéke nő az ionenergiával és az implantált ionok mennyiségével. Még az általunk használt mérsékelt ionenergiák mellett is felmerül a kérdés, hogy nem tesszük-e tönkre teljesen a gyémánt szerkezetet az implantáció során, továbbá, hogy mi történik a mintánkkal a hőkezelések hatására. Ennek monitorozására Raman-spektroszkópiai méréséket végeztem az implantált, majd hőkezelt nanogyémánt mintákon. 
A 6.7. ábrán a 30 és $20 \mathrm{keV}$ ionenergiák, valamint különböző $\left(1,5 \times 10^{17} ; 1,5 \times 10^{15} \mathrm{ion} / \mathrm{cm}^{2}\right)$ ion fluxusok mellett $\mathrm{He}^{+}$és $\mathrm{N}_{2}^{+}$ionokkal implantált nanogyémánt minták Raman-szórási spektrumában a különböző kezelések hatására bekövetkezett változásokat mutatom be. A spektrumokat a G szórási sáv tartományára egységre normáltam a spektrumalakok összevethetősége érdekében. Az egyes spektrumokat egymáshoz képest a függőleges tengely mentén eltolva ábrázoltam.

A $30 \mathrm{keV}$ ionenergiával implantált minta $488 \mathrm{~nm}$-es lézerhullámhosszal gerjesztett Ramanspektruma jelentősen megváltozik az ionimplantálás hatására a nem kezelt mintáéhoz képest (6.8.(a) ábra). Az addig $1324 \mathrm{~cm}^{-1}$-nél jól detektálható gyémánt szórási sáv az implantálást követően nem látható a spektrumban. A nanokristályos grafitra jellemző $\mathrm{D}\left(1355 \mathrm{~cm}^{-1}\right)$ szórási sáv és a grafit G (1590 $\mathrm{cm}^{-1}$ ) szórási sávja dominálják a Raman-szórási spektrumot. Ezen változás magyarázata, hogy az alkalmazott ionenergiánál a nagy iondózis $\left(1,5 \times 10^{17} \mathrm{ion} / \mathrm{cm}^{2}\right)$ következtében az implantált nanogyémánt szemcsék szerkezete roncsolódik és nem gyémánt kötések alakulnak ki. Ezek az sp ${ }^{2}$ hibridizációjú szénatomok különböző lokális struktúrákat alakítanak ki. Mivel az aromás gyürüs szerkezet Raman-szórási hatáskeresztmetszete jelentősen nagyobb az $\mathrm{sp}^{3}$ hibridizációjú gyémántszerkezethez viszonyítva, ezért a detektált spektrumot a különböző méretű aromás gyürüs klaszterek dominálják.
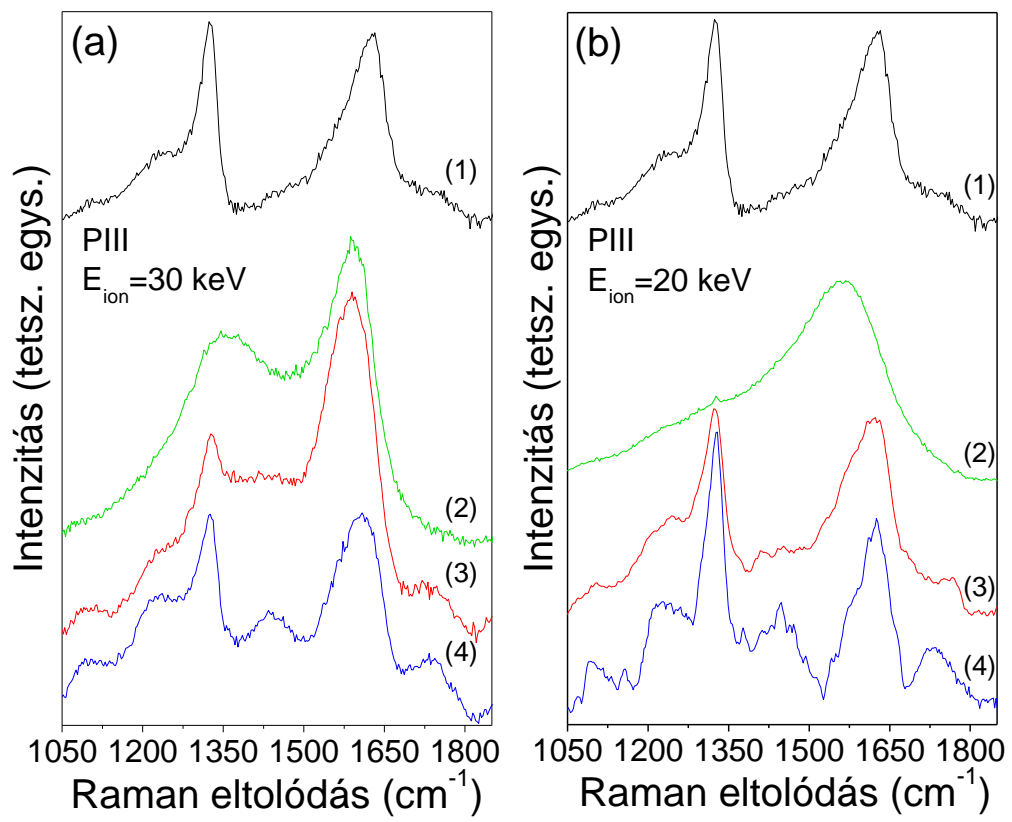

6.7. ábra: A (a) 30 és (b) 20 keV ionenergiával implantált nanogyémánt minták 488 nm-es gerjesztö hullámhosszal mért Raman-szórási spektrumának változása a különbözö kezelések hatására. Mindkét esetben az (1) görbe a nem kezelt; (2) a $\mathrm{He}^{+} / \mathrm{N}_{2}^{+}$ionimplantált; (3) az implantációt követöen vákuumban $750^{\circ} \mathrm{C}$-on hökezelt; (4) a magas hömérsékletü hökezelést követöen $450{ }^{\circ} \mathrm{C}$-on levegön hőkezelt minta Raman-szórási spektrumát jelöli. 
A nagyvákuumban végzett 2 órás, $750{ }^{\circ} \mathrm{C}$-os hőkezelés hatására azonban a Raman-spektrumban ismét detektálhatóvá válik a gyémánt szórási sávja és a Raman-spektrum kezd hasonlóvá válni a kiindulási anyag Raman-szórásához. Ez azzal hozható kapcsolatba, hogy a szerkezet relaxációja az sp ${ }^{2}$ hibridizációjú kötésszerkezet átrendeződéséhez vezet, aminek következtében az aromás gyürü struktúrák leépülnek és inkább láncszerü képződmények keletkeznek. Ezt jelzi a gyürüs szerkezetek lélegző módusához rendelhető D szórási sáv ellaposodása és a láncszerü struktúrák megjelenésére utaló szórások 1450 és $1150 \mathrm{~cm}^{-1}$ hullámszámoknál.

A $450{ }^{\circ} \mathrm{C}$-on végzett hőkezelés hatására aztán a gyémánt szórási sáv tovább erősödik, és a Raman-spektrum legintenzívebb csúcsává válik. Relatív intenzitását tekintve némileg még az eredeti minta gyémánt sávját is meghaladja, ami a szerkezet rendeződésére, valamint a felületi $\mathrm{sp}^{2}$ grafitos szénszennyezők jelentős csökkenésére utal. A spektrumban tovább erősödnek a nanogyémántra jellemző ujjlenyomat sávok 1150 és $1450 \mathrm{~cm}^{-1}$ körül. Szintén lényeges változás az $1250 \mathrm{~cm}^{-1}$ körüli szórási váll erősödése, melyet a gyémántrácsban található defektusokkal hoznak kapcsolatba, és amely utalhat az implantálással bejuttatott jelentős mennyiségű nitrogén szennyezőkre és a kialakított rácshibákra is egyaránt. Emellett az $1750 \mathrm{~cm}^{-1}$ körül megjelenő kis intenzitású szórási sáv felületi oxigénszennyezők számának növekedésére utal, mely várható az oxidációs kezelés után, mivel a szakadt kötések egy része oxigénnel zárul le.

Mivel a nanogyémánt minták implantálása során a legkisebb szerkezeti roncsolódásra törekedtünk, amit a kísérleteinkben az ionenergia és a fluxus csökkentésével próbáltunk meg kivitelezni, ezért most vizsgáljuk meg, hogy a $20 \mathrm{keV}$ ionenergiával és $10^{15}$ ion/ $\mathrm{cm}^{2}$ ionsürüséggel implantált minták esetében milyen szerkezeti változások olvashatók ki a Raman-szórási spektrumból.

A 6.7.(b) ábrán a nanogyémánt Raman-szórási spektrumának változása látható a $20 \mathrm{keV}$ ionenergia és $10^{15}$ ion $/ \mathrm{cm}^{2}$ ionsürüség mellett végzett $\mathrm{He}^{+}$és $\mathrm{N}_{2}^{+}$ionimplantálás, valamint a további hőkezelések hatására. Az implantált minta Raman-szórását egyetlen sáv uralja $1565 \mathrm{~cm}^{-1}$ csúcspozícióval, azonban nagyon széles eloszlással. A gyémánt szórási csúcsa $1326 \mathrm{~cm}^{-1}$ körül alig detektálható. A szórási spektrum jellege egy amorf szerkezet kialakulására utal, legalábbis ami a szórást domináló $\mathrm{sp}^{2}$ kötésű struktúrát illeti. Az adott paraméterekkel bíró ionnyaláb roncsolta ugyan a szerkezetet, de ahhoz nem volt sem az energia, sem pedig a dózis elég nagy, hogy az sp² kötések határozott térbeli elrendeződését eredményezze. Inkább különböző mérettel jellemezhető láncszerü struktúrák kialakulásához vezetett, nem pedig gyürüs elrendeződéshez. Ezt támasztja alá, hogy mind a $\mathrm{D}$, mind pedig a $\mathrm{G}$ szórási sáv hiányzik a Raman-spektrumból. Az $1565 \mathrm{~cm}^{-1}$-es csúcs az sp ${ }^{2}$ szénatomok alkotta, különböző méretü, láncszerű struktúrák nyújtási módusainak Raman-szórása. A $750{ }^{\circ} \mathrm{C}$-on végzett hőkezelés egyik szembetűnő hatása az intenzív gyémánt szórási csúcs megjelenése a spektrumban. Ez mutatja azt is, hogy a szerkezet relaxál és ennek következtében az sp² kötési 
szerkezetek átrendeződnek. Ez a magyarázata, hogy az $1565 \mathrm{~cm}^{-1}$-nél lévő szórási sáv pozíciója eltolódik nagyobb hullámszámok felé, ami a szerkezeti egységek méretének csökkenésével függ össze. Ugyanakkor a szórási sáv kiszélesedésének csökkenése az $\mathrm{sp}^{2}$ szerkezetek kisebb méreteloszlását tükrözi. A $450{ }^{\circ} \mathrm{C}$-on történő hőkezelés a Raman-spektrumban határozott struktúrák kialakulását eredményezi. A nanogyémántra jellemző szórási sávok mellett intenzívebbé válik az oxigén szennyezéssel kapcsolatos szórás $1730 \mathrm{~cm}^{-1}$ körül, valamint a különböző defektcentrumokkal, intrinszik hibákkal kapcsolatos szórás $\sim 1240 \mathrm{~cm}^{-1}$-nél.

Látványos különbség a nagyobb energiákkal implantált mintákhoz képest, hogy a $450{ }^{\circ} \mathrm{C}$-on, levegőn végzett hőkezelés hatására az $1240 \mathrm{~cm}^{-1}$ körüli kristályhibákhoz rendelhető szórási sáv sokkal hangsúlyosabb a $20 \mathrm{keV}$ ionenergiával implantált mintákban. Ennek lehetséges magyarázata, hogy míg a nagyobb ionenergiák és fluxus alkalmazása a nanogyémánt szemcsék külső részének kristályszerkezetét teljesen tönkreteszi, ami a hőkezelések hatására egyszerüen elég, addig a kisebb ionenergia és fluxus arányaiban véve több hibahelyet hoz létre a nanogyémántban, így mindamellett, hogy kevésbé roncsolja a mintát, hatékonyabban alakít ki színcentrumokat a 20 nm-nél kisebb átlagos szemcseméretü nanokristályokban.

\subsubsection{FIB módszerrel implantált nanogyémánt}

Napjainkban a szubmikronos méretű félvezető eszközök és más nanométeres skálán mozgó struktúrákra való növekvő igény miatt egyre nagyobb kereslet mutatkozik a felületek minél precízebb megmunkálására, ami sokszor csak fókuszált ionnyalábbal oldható meg. Emiatt az utóbbi néhány évtizedben rohamosan fejlődött a fókuszált ionnyalábos technológia, és a modern ionoptikai rendszereknek köszönhetően, melyek manapság már lehetővé teszik az ionnyaláb átmérőjét $10 \mathrm{~nm}$ alatti értékekre fókuszálni, olyan kisméretü (akár néhány 10 nanométeres) szerkezetek alakíthatóak ki, amelyek realizálása más módszerrel csak nehezen, vagy egyáltalán nem lenne megoldható. Azonban a felületi megmunkáláson kívül a módszer lehetőséget nyújt bizonyos típusú szennyezők kis mélységekbe történő bejuttatására is, így jól használható a nanogyémánt szerkezetek implantálására. A kis implantálási mélység a módszer által elérhető kis ionenergiáknak tudható be, mely jellemzően néhány keV-től néhány 10 keV-ig terjed [136].

Mivel az egyik kutatási célkitüzésem nitrogén szennyezéshez köthető komplex szerkezetü lumineszcencia centrum kialakítása volt a nanogyémánt szerkezetben, annak minél kisebb roncsolása mellett, ezért kísérleteket végeztünk a FIB módszer alkalmazásával. Ezen technikával végzett kísérleteink során az ionenergiát közel egy nagyságrenddel csökkentettük a PIII módszernél alkalmazotthoz képest. Az implantációt $2 \mathrm{keV}$-al végeztük, miközben az iondózis változatlanul $1,5 \times 10^{15}$ ion $/ \mathrm{cm}^{2}$ volt. A minták homogén implantálását az ionnyaláb $\mathrm{x}-\mathrm{y}$ irányú pásztázásával 
végeztük. Hasonlóan a korábbi kísérletekhez, egyes mintáknál csak közvetlenül $N_{2}^{+}$implantációt, míg másoknál $H e^{+}$előkezelést is alkalmaztunk.

\subsubsection{Fotolumineszcencia spektrumok}

A FIB módszerrel történő ionimplantálás, annak ellenére, hogy jelentősen kisebb ionenergiákkal történt a plazmaimmerziós ionimplantációval végzett kísérletekhez képest, mégis jelentős változást okozott a nanogyémánt lumineszcencia spektrumában.

A 6.8.(a) ábrán a $2 \mathrm{keV}$ ionenergiájú és $1,5 \times 10^{15}$ ion $/ \mathrm{cm}^{2}$ ionfluxusú $\mathrm{He}^{+}$és $\mathrm{N}_{2}^{+}$ionnyalábbal implantált minta 4,59 eV fotonenergiával gerjesztett emissziós spektrumai láthatóak implantáció előtt, az implantálást, majd pedig a komplex hőkezelési eljárást követően. Jól látható, hogy az implantálás hatására a minta szobahőmérsékletű emissziós spektruma drasztikusan megváltozik, főleg az egyes komponensek relatív intenzitásarányát illetően. A spektrum legalább két jól beazonosítható széles emissziós komponensre bontható, melyek közül az intenzívebb maximumhelye $\sim 2,8$ eV körül található. Ezt az emissziós sávot már számos korábbi vizsgálat során megfigyelték tömbi gyémántban nitrogénion implantációt követően, így az a mi mintáinkban is az implantált nitrogén általa kialakított szerkezeti hibákra utalhat. Az emissziós sávhoz tartozó hibahelyszerkezet feltehetően egy nitrogén atomból és a körülötte elhelyezkedő néhány intersticiális szénatomból áll [1]. A centrum kialakulására a FIB implantációs módszer technikai részleteiben kell a magyarázatot keresni. Szemben a PIII technikával a FIB lokálisan, kis mélységben alakít ki hibahelyeket, ahogy azt a SRIM kalkulációkból is láthattuk. Emellett, az alkalmazott kis ionenergia sokkal kevesebb szénatomot képes a gyémántrácsból kiütni és sokszor inkább csak intersticiális pozícióba tudja azt billenteni, ami jól magyarázza a FIB implantáció következtében kialakuló intersticiális szénatomokhoz és nitrogén szennyezőhöz köthető emissziós sáv dominanciáját a lumineszcencia spektrumon belül.

A másik komponens a 2,8 eV-os emissziós sáv nagyenergiájú oldalán széles spektrális eloszlású vállként jelentkezik és a korábban már többször tapasztalt 3,1-3,8 eV fotonenergia-tartományba esik. Ez a lumineszcencia sáv, amint már a PIII módszerrel kezelt mintáknál részleteztem, az implantáció által generált szerkezeti hibahelyek által kialakított emissziós centrumoknak tulajdonítható.

A komplex hőkezelések után a spektrum kiszélesedése jelentősen csökken és finomszerkezetet mutat. A 2,98 és 2,83 eV fotonenergiáknál jelentkező sávok viszonylag jól elkülönülnek és a 2,68 eVnál jelentkező emissziós váll is megjelenik a spektrumban. A lumineszcencia spektrum változásaiból arra következtethetünk, hogy a nitrogén atomok egy része komplex hibahellyé állt össze, mivel a mélykék tartományba eső sáv $N 3$ centrumhoz rendelhető. Emellett az implantálást követően a 3,6 eV körül jelentkező emissziós sáv relatív intenzitása jelentősen csökken, ami arra utal, hogy a hőkezelés 
hatására bekövetkező relaxációs folyamatok átalakították a nanogyémánt egyszerübb, vakanciákhoz rendelhető hibahelyek szerkezetét. Ennek egy lehetséges magyarázata, hogy a magas hőmérsékletü hőkezelés hatására kiváltott vakancia migráció során ezen „egyszerü” hibahelyek jelentős része össeztettebb szerkezetü nitrogént is tartalmazó hibahelyeket alkottak, melyek az N3 centrum emissziós tartományával megegyező, alakjában pedig nagyon hasonló lumineszcencia sávot hoztak létre. A vakanciák a migráció során intersticiális szénatomokkal annihilálódhatnak, csökkentve ezáltal a rácshibák koncentrációját is.
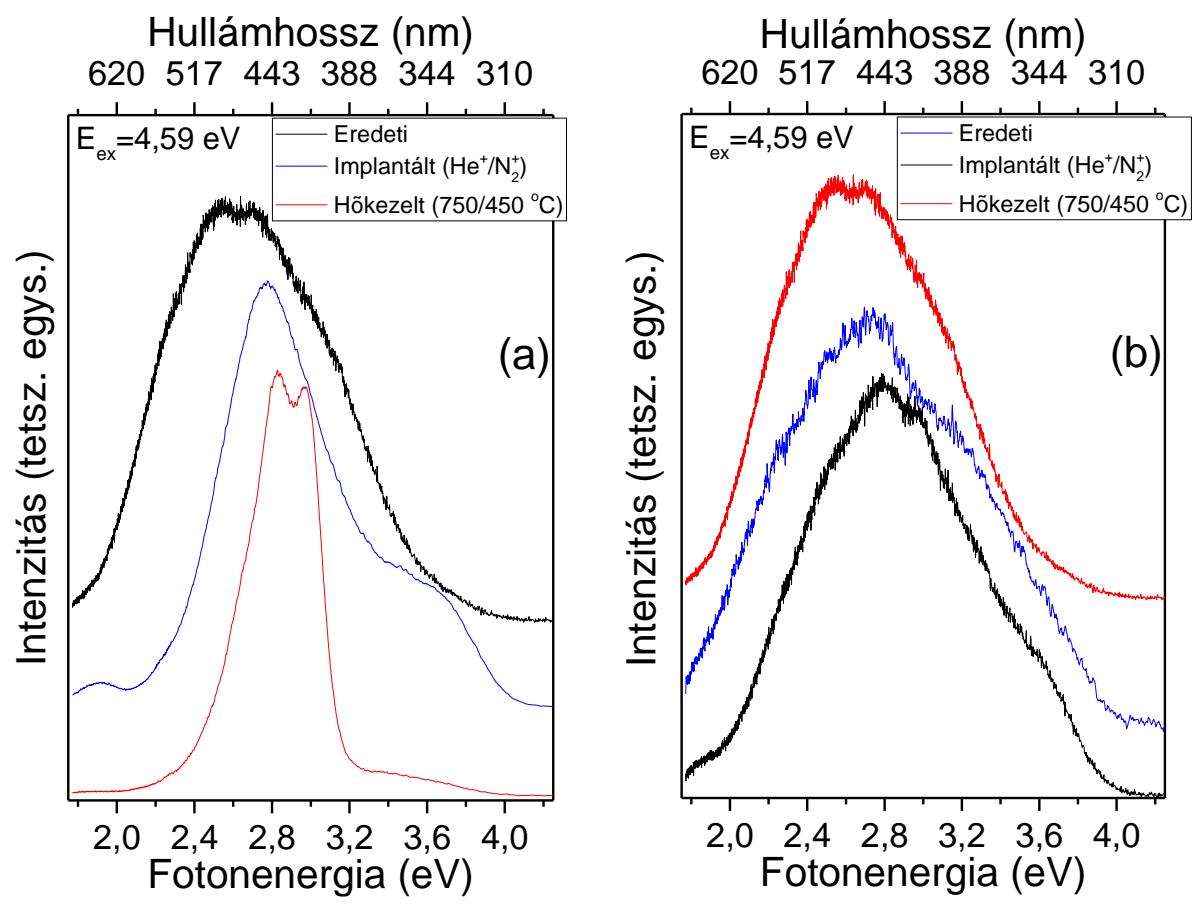

6.8. ábra: A FIB módszerrel $2 \mathrm{keV}$ ionenergiájú és $1,5 \times 10^{15}$ ion $/ \mathrm{cm}^{2}$ ionfluxusú (a) $\mathrm{He}^{+}$és $N_{2}^{+}$ionnyalábbal, valamint (b) csak $N_{2}^{+}$ionokkal implantált nanogyémánt lumineszcencia spektrumai az implantálást megelözöen, implantálás követöen, illetve a komplex hökezelés után.

Hasonlóan a PIII technikával végzett kísérletsorozathoz, a FIB implantációk során szintén vizsgáltuk a csak $N_{2}^{+}$ionok hatását a nanogyémánt lumineszcenciájára. A 6.8.(b) ábrán a $N_{2}^{+}$ionokkal implantált minta lumineszcencia spektruma látható, valamint annak változása a különböző hőkezelések hatására. Az ábrán jól látható, hogy az ionimplantálás hatására a spektrum még inkább kiszélesedik, valamint a nagyenergiájú tartomány relatív intenzitása megnő a 3,1-3,8 eV fotonenergia-tartományban. Az emissziós intenzitás növekedése az említett fotonenergia-tartományban a szerkezetbe becsapódó ionok által kialakított vakanciát is tartalmazó különböző hibahely szerkezetekkel van összefüggésben. Ugyancsak látványos változás a spektrum maximumhelyének eltolódása 2,76 eV környékére, ami a korábban leírtakhoz hasonlóan nitrogén és intersticiális szénatomokhoz köthető hibahelyek kialakulásával van összefüggésben $[134,1]$. Bár az emissziós sáv csúcspozíciója közelítőleg megegyezik a $\mathrm{He}^{+}$és $\mathrm{N}_{2}^{+}$ionokkal implantált nanogyémántban megfigyelt pozícióval, a sáv maga 
sokkal kevésbé hangsúlyos az egyéb fotonenergiáknál is megfigyelhető, hasonló intenzitású emisszió miatt. Ennek az lehet a magyarázata, hogy az ionbombázással kialakított intersticiális szénatomok kisebb arányban keletkeznek a $\mathrm{He}^{+}$és $\mathrm{N}_{2}^{+}$ionnyalábokkal végzett implantációkhoz képest.

Sokkal szembetűnőbb különbség jelentkezik az emissziós spektrumban a korábban megfigyelt változásokhoz képest a komplex hőkezelési eljárás végén. A kétlépcsős, először vákuumban $750{ }^{\circ} \mathrm{C}$ on végzett hőkezelés, majd levegőn $450{ }^{\circ} \mathrm{C}$-on végzett oxidációs folyamat hatására a korábbi kísérleti eredményektől lényegesen eltérő változások figyelhetőek meg a lumineszcencia spektrumban, mégpedig nem alakul ki a mélykék spektrális tartományba eső keskeny emissziós sáv. Tény, hogy 2,98 és 2,81 eV körül megjelenik két feloldatlan csúcs, melyek a kisszámú komplex nitrogén centrum kialakulásával függhetnek össze, azonban ezek intenzitása a többi emissziós szerkezettel összemérhető és a korábbi kísérletekben tapasztalt duplacsúcsú emissziós sávokhoz képest jelentéktelen. A hőkezelések alkalmazása ellenére a spektrum kiszélesedett és továbbra is detektálható a nagyenergiájú részen tapasztalt szerkezeti hibákhoz rendelhető széles emissziós váll, habár kisebb intenzitással. A spektrum kisenergiájú oldalán $\sim 2,2 \mathrm{eV}$ körül az intenzitás ugyancsak jelentősen csökken. Mivel ebbe a tartományba a szén divakancia hibahely emissziója esik, ezért elképzelhető, hogy a sáv intenzitásának relatív csökkenése a hökezelések hatására beindított vakancia migrációval van összefüggésben, mely az ilyen típusú hibahelyek annihilációjához vezethet, vagy a szerkezetbe bejuttatott nitrogének, vagy a kialakított intersticiális szénatomok közremüködésével [1].

A lumineszcencia mérések eredményeit a következőképpen lehet összegezni. Az $\mathrm{N}_{2}^{+}$és $\mathrm{He}^{+}$ szennyező atomoknak a nanogyémánt szemcsékbe történő bevitele fókuszált ionnyalábbal már $2 \mathrm{keV}$ ionenergiánál és viszonylag kis dózis $\left(1,5 \times 10^{15}\right.$ ion $\left./ \mathrm{cm}^{2}\right)$ mellett hatékonyan müködött a nitrogén szennyező atomokhoz köthető komplex lumineszcencia centrum kialakítása szempontjából. A 2,98 eVnál megfigyelhető keskeny, intenzív emisszió ehhez a komplex centrumhoz rendelhető optikai átmenet, míg a kisebb energiáknál (pl. $\sim 2,83 \mathrm{eV}$ és $\sim 2,68 \mathrm{eV}$ ) megfigyelhető szerkezetek a tiszta elektronátmenet rezgési oldalsávjai. A csak $N_{2}^{+}$ionok implantálása a fenti paraméterek mellett alacsony hatásfokú a komplex szennyezési centrum kialakítása szempontjából, ami a széles eloszlást mutató lumineszcencia spektrumban egy feloldatlan vállként jelentkező emissziót eredményez csupán. Ennek valószínüleg a keletkezett vakanciák kis koncentrációja az oka.

\subsubsection{Az implantálás és hőkezelés okozta kötésszerkezeti változások}

A PIII módszerrel végzett különböző ionenergiájú és fluxusú ionnyalábokkal történt kísérletek során láthattuk, hogy a kisebb ionenergiák és ionfluxusok alkalmazása a nanogyémánt kristály kisebb mértékü roncsolásához vezet. Ezek alapján azt várjuk, hogy a FIB módszerrel, 2 keV ionenergiával és 
$1,5 \times 10^{15}$ ion $/ \mathrm{cm}^{2}$ fluxussal implantált minták esetében ez a tendencia tovább javul. Az implantációs módszerek alapvető technikai különbségeiből adódóan azonban a kötésszerkezetben végbemenő változások eltérőek lehetnek a PIII módszernél tapasztaltaktól, amit az alábbi Raman-spektroszkópiai vizsgálatok is alátámasztanak.

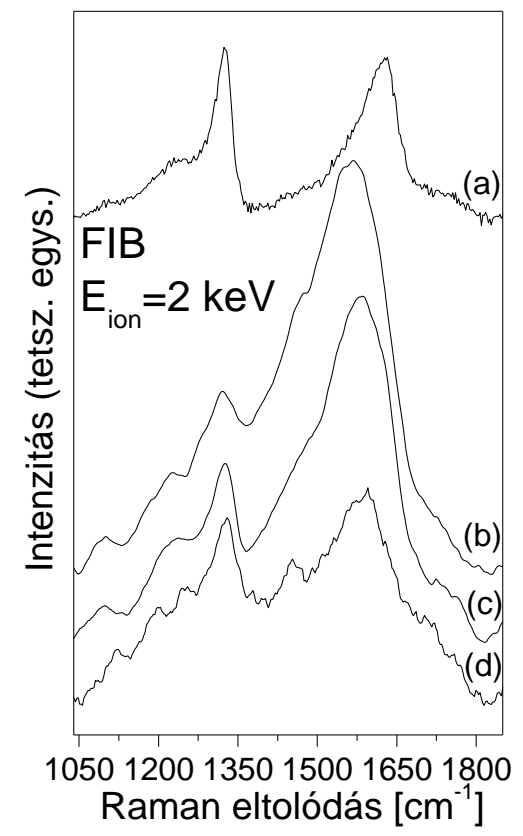

6.9. ábra: A nanogyémánt $488 \mathrm{~nm}$ gerjesztő hullámhosszal mért Raman-szórási spektrumának változása: (a) nem kezelt minta; (b) $2 \mathrm{keV}$ ionenergiával és $1,5 \times 10^{15} \mathrm{ion} / \mathrm{cm}^{2}$ fluxussal $\mathrm{He}^{+} / \mathrm{N}_{2}^{+}$ ionimplantált; (c) hökezelt $750^{\circ}$ C-on vákuumban; (d) a magas hömérsékletü hökezelést követöen 450 ${ }^{\circ}$ C-on levegön.

A 6.9. ábrán a FIB technikával implantált nanogyémánt minta $488 \mathrm{~nm}$ lézeres gerjesztéssel mért Raman-szórási spektrumai láthatóak a különböző kezelések után. A FIB módszerrel történő implantálás karakterisztikus változást eredményezett a nanogyémánt Raman-szórási spektrumában. Az implantálás után mérhető spektrum (6.9. ábra (b) görbe) nagyon emlékeztet a $20 \mathrm{keV}$-tal, PIII módszerrel implantált mintáéra (6.7.(b) ábra (2) görbe). A gyémánt szórási sáv $1324 \mathrm{~cm}^{-1}$-nél továbbra is detektálható, azonban kis szórási intenzitással és nagy félértékszélességgel. A nanogyémántra jellemző ujjlenyomat sávok 1100 és $1470 \mathrm{~cm}^{-1}$ hullámszámoknál szintén jól látszanak. Az implantálás által generált szerkezeti hibák Raman-szórása $1230 \mathrm{~cm}^{-1}$-nél jól beazonosíthatóvá válik. Azonban az $1572 \mathrm{~cm}^{-1}$-nél megjelenő G szórási sáv összetett, ami gyürüs aromás klaszterek jelenlétére utal. Ezt a gyémánt szórási sávja alatt, széles háttérként megjelenő D sáv is alátámaszt. Szemben a PIII kezeléseknél tapasztaltakkal, ezen kötésszerkezetek nem fedik be teljesen a gyémánt szemcsék felületét, ezért mérhető a gyémánt csúcs a FIB esetben. A G tartomány szórásához különböző klaszterméretű $\mathrm{sp}^{2}$ kötéseket tartalmazó láncok is hozzájárulnak. 
A $750{ }^{\circ} \mathrm{C}$-os hőkezelés szembetűnő változást eredményezett a gyémánt Raman-szórási csúcsában. A nem tökéletes kristályszerkezettel kapcsolatos szórási váll $\sim 1230 \mathrm{~cm}^{-1}$ környékén már nem detektálható és a gyémánt szórási sáv kiszélesedése is jelentősen csökkent. A nem gyémánt kötéseket tartalmazó klaszterek szerkezete is változott. Az aromás gyürüs struktúrák jelentősen visszaszorultak, amit a D sáv szórási tartományában csökkenő intenzitás is jelez. A $450{ }^{\circ} \mathrm{C}$-os hőkezelés hatására az $\mathrm{sp}^{2}$ kötések alkotta szerkezetek jelentős része eloxidálódik. Ezt tükrözi a $\mathrm{G}$ szórási sáv intenzitásának jelentős mértékü gyengülése a gyémánt szórási sávjához képest. Emellett kierősödnek a nanogyémánt ujjlenyomat sávjai is.

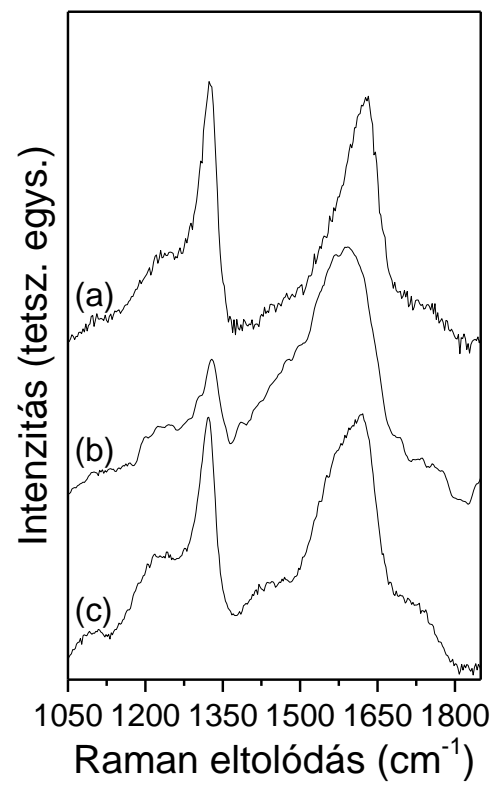

6.10. ábra: A FIB módszerrel (b) 2 keV ionenergiájú és $1,5 \times 10^{15} \mathrm{ion} / \mathrm{cm}^{2}$ fluxusú $\mathrm{N}_{2}^{+}$ionnyalábbal implantált és (c) kétlépcsős hökezelésnek kitett nanogyémánt $488 \mathrm{~nm}$ lézerhullámhosszal gerjesztett Raman-spektrumai. Összehasonlitás céljából a (a) nem implantált nanogyémánt Raman-spektrumát is ábrázoltam.

Foglalkozzunk most azzal a kísérletsorozattal, amikor a FIB implantálás csak $N_{2}^{+}$ionnyalábbal történt. A megfelelő Raman-szórási spektrumokat a 6.10. ábra mutatja. Egyaránt enyhe grafitosodásra utal a $\mathrm{G}$ sáv szórási tartományának és a hozzá tartozó D sávnak az intenzitás növekedése az ábra (b) görbéjén. A gyémánt sáv szórási intenzitásának csökkenése is ennek a következménye. A G sáv kiszélesedése a kisebb hullámszámok felé arra utal, hogy $\mathrm{sp}^{2}$ kötéseket tartalmazó láncok is képződnek az implantálás során. Részben ez a kiszélesedése a G szórási sávnak, valamint az $1326 \mathrm{~cm}^{-1}$-nél megfigyelhető gyémánt szórási csúcs elfedi a gyürüs szerkezetek lélegző módusához rendelhető D sávot $1360 \mathrm{~cm}^{-1}$ környékén. A gyémántrácsnak az implantáció miatti roncsolódását mutatja a gyémánt sáv kiszélesedése és a szórási intenzitás relatív növekedése az $\sim 1230 \mathrm{~cm}^{-1}$ körüli hullámszámnál. 
A komplex hőkezelési eljárás eredményeként bekövetkező szerkezeti változásokat a 6.10. ábra (c) görbéje mutatja. A gyémánt szórási sáv relatív intenzitása megnő, emellett a gyémánt rácsban generált hibahelyek karakterisztikusabb szórási szerkezetet mutatnak $1230 \mathrm{~cm}^{-1}$ körül. A nanogyémántra jellemző ujjlenyomat sávok jól elkülönülnek. A G szórási sáv relatív intenzitása jelentősen csökken a spektrumban, ugyanakkor erősödik a felületi OH csoportokhoz rendelhető szórási sáv $\sim 1620 \mathrm{~cm}^{-1}$ körül. Az oxidációs kezelés hatására a felületi oxigénkötések szórási intenzitása is megnő $1720 \mathrm{~cm}^{-1}$ hullámszámnál.

Összefoglalásként elmondható, hogy a FIB implantálási módszer alkalmazása kevésbé károsítja a nanogyémánt mintát, mint a PIII technikával történő implantálás. Ez nem csak az alkalmazott ionenergiával, de az implantációs technikák közötti implantálási mechanizmusokkal is összefüggésben állhat. A FIB implantálás során az ionok egy nyalábba fókuszálva érik el a nanogyémánt felületét, lokálisan lehetővé téve a nagymennyiségü nitrogénszennyezők bevitelét, míg a PIII implantálás során a minta teljes felülete különböző ionütközéseknek van kitéve, amely nagyobb mértékű grafitosodást okoz, ahogyan ez a Raman-spektrumokban is jól látható.

\subsubsection{Az implantációs technikákkal kialakított $N 3$ centrum emissziójának jellemzése}

A korábban bemutatott PIII és FIB technikával implantált, majd komplex hőkezelési eljárásnak alávetett nanogyémánt lumineszcencia spektrumai azt mutatták, hogy mindkét implantációs módszerrel hatékonyan lehet kialakítani olyan szennyezési centrumot a $\sim 12 \mathrm{~nm}$ átlagos szemcseméretü nanogyémántban, amely a mélykék hullámhossztartományba eső, keskeny emissziós sávval jellemezhető és további fontos tulajdonsága, hogy az emissziója szobahőmérsékleten is intenzív. A tömbi gyémántban vizsgált nitrogén szennyezéshez köthető lumineszcencia centrumokra vonatkozó korábbi kísérleti eredmények alapján a kialakított keskeny emissziós sáv nagy valószínűséggel az úgynevezett $N 3$ centrumhoz rendelhető, ami egy szénvakancia körül elhelyezkedő 3 nitrogénatomból álló hibahely szerkezettel rendelkezik [52]. Az említett emissziós centrum jellegzetessége a tiszta elektronátmenet, vagyis a ZPL 2,985 eV fotonenergiánál található és hozzá egy finomszerkezettel rendelkező fonon-oldalsáv (a ZPL elektron-fonon csatolás révén keletkező replikája) kapcsolódik a keskeny emissziós sáv kisenergiájú oldalán. Abból kiindulva, hogy a centrum ZPL-jének spektrális tulajdonságai, mind a fonon oldalsáv finomszerkezete, mind pedig az emissziós sáv gerjesztési tulajdonságai a centrum egyedi jellemzőit tükrözik, ezért a nanogyémánton mért lumineszcencia spektrumokat és azok finomszerkezetét részletesen analizáltam. Emellett meghatároztam a gerjesztési spektrumot szobahőmérséklet mellett, alacsony hőmérsékleten is. Az ezekre vonatkozó eredményeket a következő alrészekben ismertetem. 


\subsubsection{A szobahőmérsékleten mért lumineszcencia spektrum spektrális tulajdonságai}

Azzal a céllal, hogy a nanogyémántban különböző technikákkal kialakított $N 3$ centrum emissziós tulajdonságairól részletesebb képet kapjak, továbbá, hogy össze tudjam hasonlítani az egyes implantációs technikákkal kialakított lumineszcencia centrumok főbb spektrális tulajdonságait, elvégeztem a szobahőmérsékleten mért lumineszcencia spektrum finomszerkezetének és az illesztéssel meghatározott ZPL-ek spektrális paramétereinek részletes analízisét. Ennek érdekében, első lépésként korrigáltam a spektrum alapvonalát a nagyenergiájú tartománynál 3,1-3,9 eV között jelentkező, különböző szerkezeti hibahelyekhez rendelhető széles emissziós sávra, majd az így kapott spektrumalak nagyenergiájú részétől a kisenergiák felé indulva kijelöltem a ZPL tartományát egészen az első lokális maximumhelyig ( 2,98 eV) és a kapott tartományra Gauss görbét illesztettem (6.11. ábra). Szimmetrikus vonalalak esetében, amit korábbi irodalmi eredmények is alátámasztanak az N3 centrum ZPL-jére vonatkozóan [62], viszonylag elég pontosan meghatározhatóak a ZPL spektrális paraméterei már a görbe egyik oldalának ismeretében is. Ez esetünkben a nagyenergiájú oldalt jelenti, mivel az erős elektron-fonon csatolás következtében a zérusfonon vonal és a rezgési oldalsáv nagymértékben átlapol [137]. Az illesztéssel meghatározott ZPL paramétereket a 6.1. táblázatban foglalom össze. Ugyanebben a táblázatban tüntetem fel az egyes mintákra jellemző rezgési energiákat, melyekkel kölcsönhat a centrum az optikai gerjesztés során. Ezek meghatározása a lumineszcencia spektrum ZPL mamximumhelyének és a fonon oldalsávban megjelenő szerkezetek pozíciójának különbségképzésével történt. Itt megjegyezném, hogy ezen értékek csak közelítőlegesek, mivel pontos meghatározásuk az egyes fonon-szerkezetek nagy kiszélesedése és egymással való átfedése miatt nem lehetséges.

A nanogyémántban mért ZPL csúcspozíciója megegyezik, vagy alig tér el az N3 centrum tömbi gyémántban mért csúcspozíciójától, az 2,984-2,986 eV között változik. Meglepően nagy azonban a ZPL félértékszélessége (68-75 meV). Még a FIB módszerrel, $2 \mathrm{keV}$ ionenergiával kialakított $N 3$ centrum ZPL-jének 74 meV-os vonalkiszélesedése is meglehetősen nagy érték. A ZPL ilyen nagymértékü kiszélesedése valószínüleg a vonalalak inhomogén kiszélesedésével kapcsolatos. A lumineszcencia mérésekor nagyszámú $N 3$ centrumot gerjesztünk, és ha az egyes centrumok lokális környezete nem teljesen azonos mértékben relaxálódott a különböző gyémánt nanoszemcsékben, akkor mind a ZPL csúcspozíciója, mind pedig a kiszélesedése centrumról centrumra változhat. Ha több ilyen centrum emisszióját mérjük egyszerre, akkor egy inhomogénen kiszélesedett ZPL-t kapunk. Ez a kiszélesedés jóval nagyobb lehet, mint egy egyedi centrum homogénen kiszélesedett ZPL-je. Mindez persze akkor lehetséges, ha a centrumnál a szennyező atom és a vakancia által a kristályszerkezetben generált lokális belső feszültségek eltérőek. Tekintettel arra, hogy szennyező atomok jelentős 
mennyiségét juttatjuk be a nanogyémánt szemcsékbe, a gyémánt rács lokális szerkezeti relaxációjának mértéke könnyen eltérhet az egyes szemcsékben. A ZPL inhomogén kiszélesedése az oka annak, hogy a rezgési oldalsávtól nem válik külön, ugyanis az egyes centrumokhoz tartozó ZPL-ek és a fonon oldalsáv szerkezetei átfedhetnek egymással (a nagyobb energiánál emittáló N3 centrum fonon oldalsávja részben átfedhet a kisebb energiáknál emittáló $N 3$ centrum ZPL-jével). A centrum kialakítását követően a lokális belső feszültség nő a gyémántrácsban, amire a gyémánt Raman-szórási sávjának kiszélesedése is utal (lásd a 6.1.2.3. alfejezet megfelelő részét). Mindezek ellenére, a ZPL maximumhelye megerősíti azt a feltételezést, mely szerint $N 3$ komplex centrumot alakítottunk ki. Ennek további bizonyítékai a fonon oldalsáv analíziséből kapott eredmények.

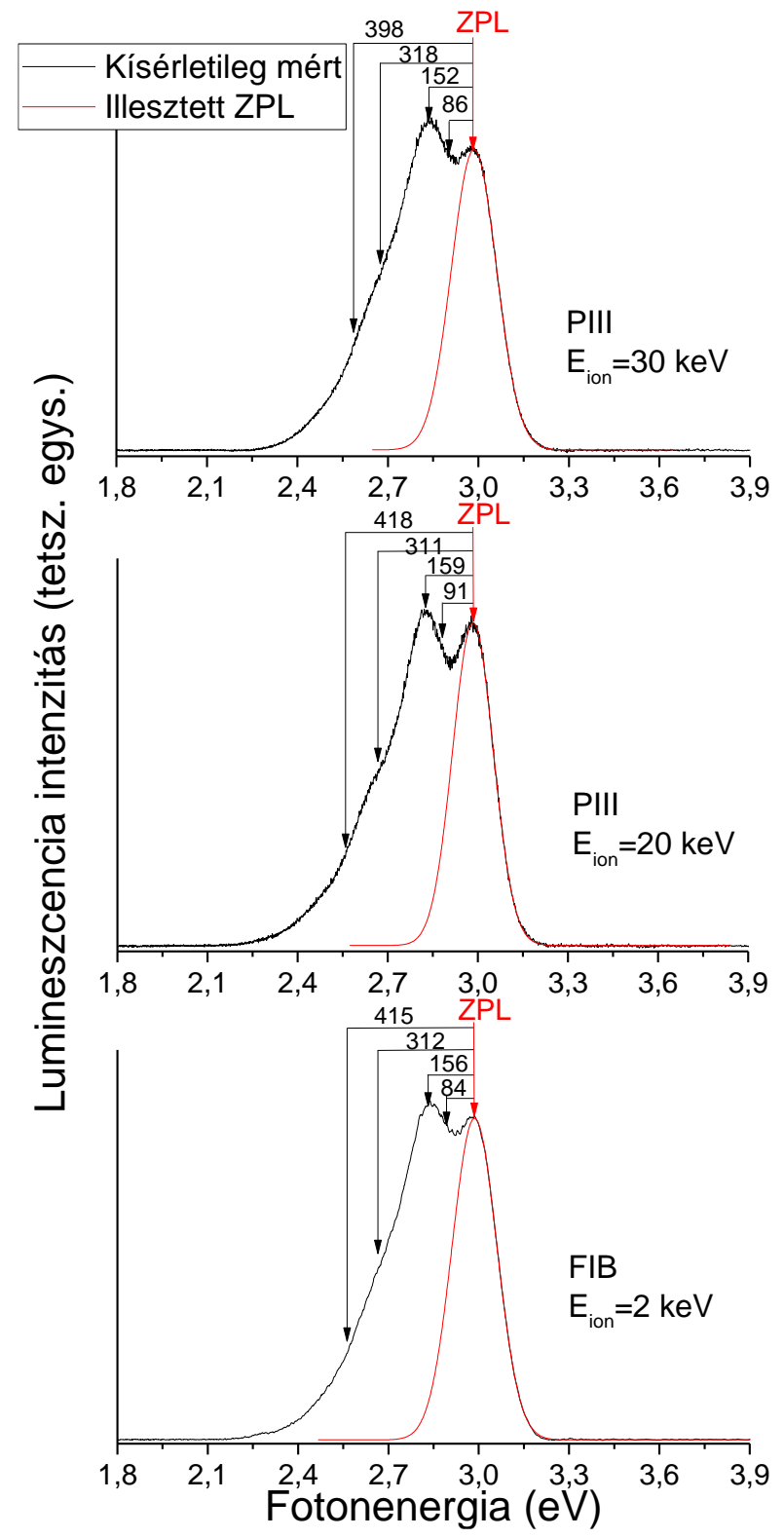

6.11. ábra: A nanogyémántban különbözö implantációs módszerekkel kialakitott N3 centrumok 4,59 eV fotonenergiával gerjesztett szobahömérsékletü lumineszcencia spektrumai. A vörös színü görbék a Gauss illesztéssel meghatározott ZPL-ek alakját mutatják. 
A 6.11. ábrán jól látható, hogy az illesztett Gauss görbe jól követi a kísérletileg mért spektrumban a ZPL nagyenergiájú oldalát mindegyik esetben. Azonban a kisenergiájú oldalon, a csúcspozíció közelében, leginkább a PIII technikával, $20 \mathrm{keV}$ ionenergiák alkalmazása mellett kialakított centrum esetében a legnagyobb mértékü az átfedés. Szintén ennél a mintánál a leghangsúlyosabbak a fonon oldalsáv egyes finomszerkezetei, ami az implantálási paramétereknek tudható be. A kisebb ionenergia és dózis kevésbé roncsolta a nanogyémánt kristályokat, amit a Ramanszórási vizsgálatok is alátámasztanak, így az egyes rezgési módusok terjedése kevésbé torzult kristályrácsban történik. A fonon oldalsáv finomszerkezetének hangsúlyossága kiemelten igaz a 91 meV és a $~ 311$ meV körül megjelenő vállakra. Míg elöbbi az egyfononos kölcsönhatás energiatartományába tartozik és akusztikus fononokkal való kölcsönhatáshoz rendelhető, addig utóbbi többfononos kölcsönhatással magyarázható. Szintén a többfononos kölcsönhatás eredménye a 410 meV körül jelentkező gyenge, a nagyobb energiáknál jelentkező szerkezetekkel erősen átlapoló váll is [57]. Ezen kívül mindegyik spektrumról elmondható, hogy a rezgési oldalsáv legintenzívebb szerkezete a ZPL maximumától átlagosan 156 meV-ra lévő fononcsúcs, mely valószínüleg longitudinális optikai (LO) fononokkal való kölcsönhatáshoz rendelhető, mivel a gyémánt rezgési állapotsürüségének eloszlásában 166,7 meV körül LO fononok intenzív, keskeny sávja található [15].

6.1. táblázat A különbözö implantációs paraméterek mellett kialakitott N3 centrumok illesztéssel meghatározott ZPL paraméterei és a karakterisztikus fonon módusok rezgési energiái.

\begin{tabular}{ccccccc}
\hline Ionenergi (keV) & ZPL (eV) & FWHM (meV) & \multicolumn{3}{c}{ Fonon módusok (meV) } \\
\hline 30 (PIII) & $2,985 \pm 0,002$ & $75 \pm 3$ & $86 \pm 5$ & $152 \pm 4$ & $318 \pm 8$ & $398 \pm 10$ \\
20 (PIII) & $2,984 \pm 0,003$ & $68 \pm 4$ & $91 \pm 4$ & $159 \pm 4$ & $311 \pm 7$ & $418 \pm 10$ \\
2 (FIB) & $2,986 \pm 0,002$ & $74 \pm 2$ & $84 \pm 4$ & $153 \pm 5$ & $310 \pm 7$ & $415 \pm 9$ \\
\hline
\end{tabular}

Összehasonlítva a nanogyémánt mintáinkban ionimplantálás és komplex hőkezelés alkalmazásával kialakított $N 3$ centrumok domináns rezgési energiáit az irodalomban található, tömbi kristályra vonatkozó eredményekkel kijelenthető, hogy az illesztési hibákat is figyelembe véve a nanogyémánt minta emissziójának fonon oldalsávjához rendelhető rezgési energiák jó egyezést mutatnak a tömbi gyémántban tapasztalt domináns rezgési energiákkal. A tapasztalt kismértékü eltérés a hibahelyszerkezet torzulásával lehet összefüggésben, amit akár a centrumok környezetében lévő belső feszültség is okozhat. A maradék belső feszültség jelenléte a nanokristályokban a magas hőmérsékletü hőkezelés ellenére, valószínüleg a kristályok nm-es méretével függ össze, aminek következtében már a kevés szennyezőatom bevitele után kialakuló szerkezeti feszültség is a kötések torzulását eredményezheti. A vakanciát tartalmazó úgynevezett „lágy” centrumok pedig érzékenyek lehetnek ezekre a lokális torzulásokra. 


\subsubsection{Az $N 3$ centrum lumineszcencia spektruma alacsony hőmérsékleten}

A gyémánt magas Debye hőmérséklete $(2220 \mathrm{~K})$ miatt az egyes optikailag aktív hibahelyek lumineszcencia tulajdonságai nem változnak jelentős mértékben a minták alacsony hőmérsékletű vizsgálatai során, mivel már a szobahőmérséklet is alacsony hőmérsékletnek számít [138]. Azonban a gyémántban lévő több optikai centrum lumineszcenciájának alacsony hőmérsékleten mért jellemzői arra engednek következtetni, hogy az N3 centrumot tartalmazó nanogyémánt minták emisszióját érdemes alacsony hőmérsékleten is megvizsgálni. A hőmérséklet csökkenése hatással van a centrum elektronátmenetére jellemző elektron-fonon csatolásra, és így a ZPL-hez kapcsolódó fonon oldalsávra is. A hőmérséklet csökkenésével a ZPL inhomogén kiszélesedése ugyan nem változik, azonban a homogén kiszélesedés csökken. Mindez hozzájárul ahhoz, hogy a spektrum finomszerkezete jól felismerhetővé válik. Ezen megfontolások alapján vizsgáltam a nanogyémánt mintákban kialakított N3 centrumok emissziós tulajdonságait $8 \mathrm{~K}$ hőmérsékleten.

Korábban láthattuk, hogy a nagyobb energiával végzett ionimplantálás során a nanogyémánt kristály jelentősebb mértékben sérül, ennek következtében nagyobb a kialakuló belső feszültség a mintában, ezért az alacsony hőmérsékletü vizsgálatokat a legkisebb energiával implantált mintán végeztem. Várható, hogy a kisebb ionenergia és a célzott ionsugár által kialakított $N 3$ centrumok környezete ezeknél a mintáknál kevésbé sérült, így az esetlegesen az emissziós spektrum finomszerkezetében tapasztalt változások sokkal inkább az eredeti nanogyémánt szerkezethez köthetőek, mint a nagyobb energiával kialakított mintáknál.

A 6.12. ábrán a FIB technikával (2 keV) kialakított $N 3$ centrum $8 \mathrm{~K}$ és $300 \mathrm{~K}$ hőmérsékleteken mért lumineszcencia spektrumai láthatóak. A lehűtés határozott változást eredményezett a lumineszcencia spektrum kiszélesedésében és finomszerkezetében egyaránt. Utóbbi különösen jól látszik az ábrán betétként látható kinagyított spektrumrészleten.

A 2,985 eV fotonenergiánál található ZPL félértékszélessége jelentősen csökken, hasonlóan a hozzá tartozó fonon oldalsáv intenzitásához. Az említett változások következtében a centrum spektrumát alkotó zérusfonon vonal és rezgési oldalsáv nagyobb mértékben válik külön egymástól a szobahőmérsékletű spektrumhoz képest. Ez lehetővé teszi az ionimplantálással kialakított $N 3$ centrum ZPL spektrális tulajdonságainak pontosabb meghatározását. A ZPL-en kívül a rezgési oldalsáv is szerkezetgazdagabbá válik, valamint az egyes fononcsúcsok intenzitásaránya is megváltozik a lehütés hatására. A Gauss görbe illesztésével kapott ZPL paramétereket és a fonon oldalsáv rezgési módusainak energiáit a 6.2. táblázatban tüntetem fel. 


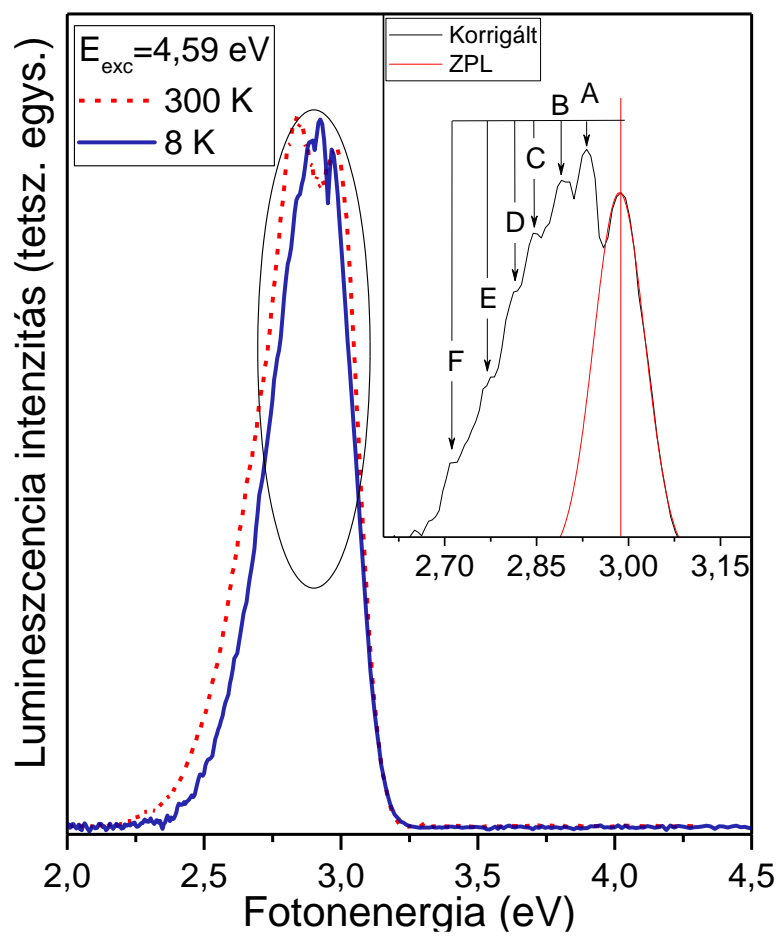

6.12. ábra: A FIB (2 keV) technikával és komplex hökezeléssel a nanogyémántban kialakitott N3 centrum szobahömérsékleten $(T=300 \mathrm{~K})$ és alacsony hömérsékleten $(T=8 \mathrm{~K})$ felvett lumineszcencia spektrumai. Az ábra jobb felső részében a háttér emisszióra korrigált alacsony hömérsékletü spektrum nagyitott képe látható a finomszerkezet könnyebb beazonosithatósága céljából.

Összehasonlítva az alacsony hőmérsékletü mérés illesztésével meghatározott zérusfonon sáv csúcspozícióját és félértékszélességét a szobahőmérsékletűvel, elég jelentős eltérést tapasztalhatunk utóbbi paraméter esetében. Míg a csúcspozíció 2,986 eV-ról 2,985 eV-ra tolódik, amely változás valójában csak a szobahőmérsékleten történő illesztés hibájából fakad, addig a félértékszélesség 74 meV-ról 42 meV-ra csökken. Bár a félértékszélesség több, mint 40\%-kal csökken, de még így is legalább a négyszerese a tömbi kristályban vizsgált N3 centrum vonalkiszélesedésének [57]. Ennek valószínűsíthető magyarázata, hogy bár a hőmérséklet csökkenésével az elektron-fonon kölcsönhatás erőssége csökken, ami egyértelmüen a vonalkiszélesedés homogén komponensének csökkenését eredményezi, azonban a sztatikus kiszélesedés, vagyis, hogy a gerjesztett tartományban lévő egyes színcentrumok ZPL-jének csúcshelyzete, melyek környezete különböző mértékben relaxálódott, továbbra is egy eloszlást mutat. Ezen centrumokhoz tartozó ZPL vonalak átlapolnak egymással, ezáltal pedig egy kiszélesedett zérusfonon vonalat mérünk kísérletileg [139].

Vizsgáljuk meg most a fonon oldalsáv finomszerkezetében a lehütés hatására bekövetkezett változásokat. Amint az a spektrumon (6.12. ábra) látható, a fonon oldalsáv intenzitása jelentősen csökken a 8 K-en mért lumineszcencia spektrumban. Még inkább szembetünő a változás a ZPL-től távolodva az egyre kisebb energiák felé, melyek a többfononos kölcsönhatáshoz rendelhető rezgési 
sávoknak tulajdoníthatóak. Ennek magyarázata, hogy alacsony hőmérsékleten a többfononos kölcsönhatás valószínüsége lecsökken, így az ezekhez tartozó szerkezetek intenzitása is mérséklödik a lumineszcencia centrum rezgési oldalsávjában.

6.2. táblázat A FIB módszerrel kialakitott N3 centrum $8 \mathrm{~K}$ hömérsékleten felvett emissziós spektrumából illesztéssel meghatározott ZPL paraméterek és a karakterisztikus fonon módusok rezgési energiái.

\begin{tabular}{|c|c|c|c|c|c|c|c|}
\hline \multirow{2}{*}{ ZPL (eV) } & \multirow{2}{*}{ FWHM (eV) } & \multicolumn{7}{|c|}{ Fonon módusok (eV) } \\
\cline { 3 - 8 } & & $\mathrm{A}$ & $\mathrm{B}$ & $\mathrm{C}$ & $\mathrm{D}$ & $\mathrm{E}$ & $\mathrm{F}$ \\
\hline 2,985 & 0,042 & 0,047 & 0,090 & 0,143 & 0,174 & 0,220 & 0,276 \\
$\pm 0,002$ & $\pm 0,0037$ & $\pm 0,002$ & $\pm 0,003$ & $\pm 0,003$ & $\pm 0,004$ & $\pm 0,005$ & $\pm 0,005$ \\
\hline
\end{tabular}

A másik figyelemre méltó változás, hogy a fonon oldalsáv finomszerkezete sokkal karakterisztikusabbá válik, emellett jól detektálhatóak az olyan fononcsúcsok is, melyek a szobahőmérsékletű spektrumban nem voltak láthatóak az egyes rezgési sávok átlapolása miatt. Ezekhez tartozik a ZPL csúcshelyzetétől 47 meV-ra megjelenő szerkezet. Mivel a gyémántrácshoz tartozó rezgések energiája a 70-168 meV tartományba esik, ezért az ennél nagyobb, vagy kisebb frekvenciájú rezgéseket lokális, vagy kvázi-lokális rezgéseknek tulajdonítják [15]. A 47 meV-nál jelentkező szerkezet kvázi-lokális rezgésnek tulajdonítható és a centrum vakancia szegmenséhez rendelhető, melyet már korábban tömbi kristályban vizsgált $N 3$ centrum lumineszcencia spektrumában is megfigyeltek alacsony hőmérsékleten [57]. A vakanciára utaló szerkezet a fonon oldalsávban további bizonyíték arra, hogy az ionimplantálással és komplex hőkezeléssel $N 3$ centrumot alakítottunk ki a nanogyémánt kristályokban.

A vakanciához rendelhető fononszerkezeten kívül megjelennek még lokális csúcsok a ZPL-től 143, 220 és 276 meV-ra, melyek nem figyelhetőek meg a szobahőmérsékletű rezgési oldalsávban. Míg elöbbi az egyfononos kölcsönhatás tartományába esik és a fononállapotsűrüségi spektrumban a 146 meV-nál megjelenő optikai és akusztikus fononrezgések által okozott lokális maximumhoz rendelhető, addig a két kisebb energiánál megjelenő szerkezet a kétfononos tartományba esik és a 90 meV-os akusztikus fononokkal történő kölcsönhatás replikái $[1,15,57]$.

A 8 K-en végzett lumineszcencia mérések megerősítik a nanogyémántban kialakított N3 centrumszerkezetre vonatkozó feltételezéseket, amit mind a ZPL csúcspozíciója, mind pedig a fonon oldalsáv rezgési szerkezetei alátámasztanak. Utóbbinál a ZPL-től 47 meV-ra jelentkező rezgési szerkezet egyértelműen a centrum vakacia-fragmenséhez rendelhető. 


\subsubsection{A kialakított N3 centrum vizsgálata fotolumineszcencia gerjesztési spektroszkópiával}

Fényabszorpció során, ha a beérkező fotonok energiája megfelelö, akkor a gyémántban található optikailag aktív hibahelyek által a tilos sávban kialakított elektronnívók részlegesen, vagy teljesen betöltésre kerülnek, és a töltések sugárzó rekombinációja során kibocsátott lumineszcencia spektrum finomszerkezettel rendelkezik. Az emissziós sáv zérusfonon vonala a fononmentes elektronátmenet, melynek ismétlődése az elektron-fonon csatolás következtében adja a ZPL rezgési oldalsávját a spektrum kisenergiájú oldalán. Az ilyen módon kialakuló emissziós sáv spektrális analíziséből egyértelmủen beazonosítható a lumineszcencia centrum, melynek atomi szerkezete más független mérésekből ismert. Sajnos azonban a lumineszcencia spektrumból nem határozható meg a hibahely által létrehozott nívók pozíciója a tilos sávon belül. Ezen információkat a centrum fotolumineszcencia gerjesztési spektrumának analíziséből tudjuk megszerezni, melynek során az adott emissziós sáv intenzitását vizsgáljuk a gerjesztő hullámhossz függvényében. Hasonló információkhoz juthatunk az abszorpciós vizsgálatokból is, de annak értelmezése sokkal bonyolultabb lehet. Ennek az az oka, hogy míg az abszorpció során a minta összes hibahelye által elnyelt fényt detektáljuk, addig a gerjesztési spektrum csak azokat az abszorpciós átmeneteket detektálja, amelyek hatékonyak az adott emissziós centrum gerjesztése szempontjából.

Az irodalomban a gyémánt egykristályban és mikron méretű gyémántkristályokat tartalmazó CVD rétegekben kialakított $N 3$ centrum gerjesztési spektruma jól ismert, ezért azt érdemes összevetni a PIII és FIB módszerekkel implantált nanogyémántban kialakított $N 3$ centrum gerjesztési spektrumával, hogy további megerősítést kapjunk arra vonatkozóan, hogy milyen centrumot alakítottunk ki a nanogyémántban. A nanogyémántban kialakított centrum gerjesztési spektrumának vizsgálata a kísérleti részben részletesen leírt Horiba Jobin Yvon FL-3 típusú készüléken történt szobahőmérsékleten és 8 K-en.

A 6.13. ábrán a FIB ionimplantációs módszerrel és komplex hőkezelési eljárás alkalmazásával kialakított $N 3$ centrum emissziós és gerjesztési spektruma látható $8 \mathrm{~K}$ hőmérsékleten. Az emissziót 3,26 eV (380 nm) fotonenergiával gerjesztettem és a ZPL csúcsnál $3 \mathrm{meV}$ feloldóképességgel mértem, míg a gerjesztési spektrum fölvétele $2,97 \mathrm{eV}(417 \mathrm{~nm})$ fotonenergiánál történt $28 \mathrm{meV}$ sávszélességben. A nanogyémánt mintánkban kialakított $N 3$ centrumok gerjesztési spektruma alacsony hömérsékleten kis mértékben ugyan, de eltér az irodalomban tömbi gyémántra vonatkozóan publikált eredményektől. Mielőtt diszkutálnánk ezen eltéréseket, utalnunk kell arra, hogy a ZPL a gerjesztési spektrumban azért nem látszik, mert abban a fotonenergia-tartományban mértük a lumineszcencia intenzitást, tehát gerjesztésre azokat a fotonenergiákat nem használhattuk, így abban a tartományban 
csupán korrigáltuk a gerjesztési spektrumot. Lineáris elektron-fonon csatoláskor általában várható, hogy az emissziós és gerjesztési spektrumok tükörszimmetrikusak a ZPL-hez képest. Ha azonban az $N 3$ centrum gerjesztett állapotában ( ${ }^{2} \mathrm{E}$ állapot) az elektron más fononokkal lép kölcsönhatásba, mint a centrum alapállapotában $\left({ }^{2} \mathrm{~A}_{1}\right.$ állapot), akkor ez a tükörszimmetria nem teljesül.

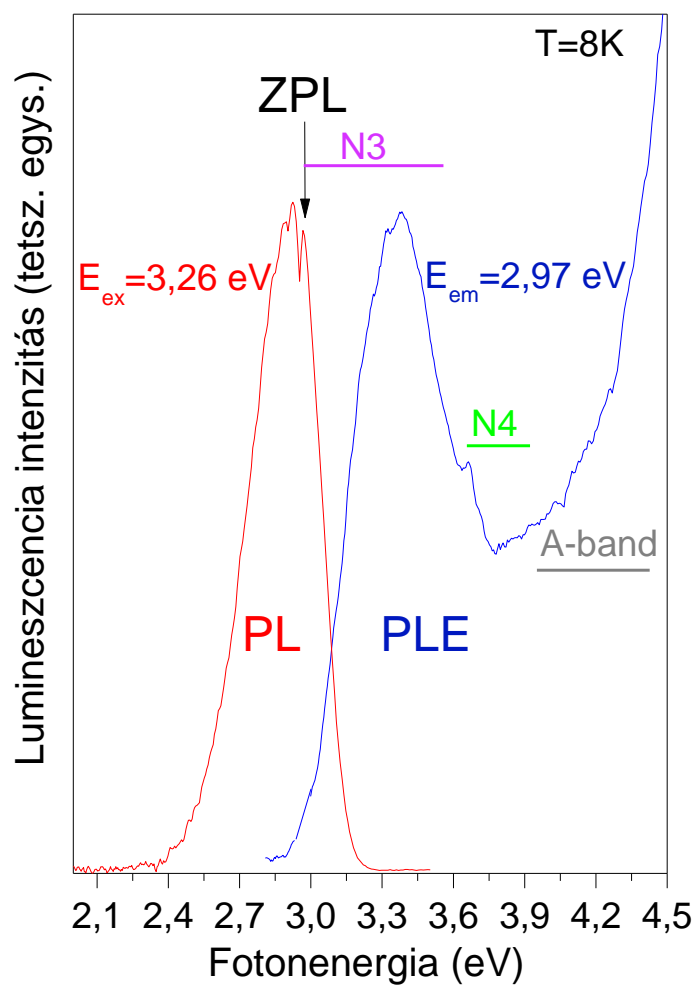

6.13. ábra: A nanogyémántban FIB implantációs módszerrel kialakitott N3 centrum emissziós és gerjesztési spektrumai 8 K hömérsékleten.

A gerjesztési spektrum fonon oldalsávja $3-3,7 \mathrm{eV}$ fotonenergia-tartományra terjed ki, maximumhelye pedig 3,38 eV körül található, hasonlóan az irodalomban publikált eredményekhez [52, 53]. A gerjesztési spektrum csúcspozíciója és az emissziós intenzitás csökkenése a spektrum nagyenergiájú oldalán arra enged következtetni, hogy az N3 centrum elektronnívói a tilos sávban lévő lokalizált állapotok és a legkisebb energiájú gerjesztett állapot $\sim 0,4$ eV-ra találhatóak a vezetési sáv aljától. Ez az érték jó egyezésben van az N3 centrummal kapcsolatos termostimulált lumineszcencia mérési eredményeivel [140]. A gerjesztési spektrum maximumánál nagyobb energiáknál az emissziós intenzitás csökken, mivel a gerjesztés az elektronokat már a vezetési sávba juttatja és ahhoz, hogy ezek sugárzóan rekombinálódjanak az N3 centrumnál, csapdázódniuk kell a centrum tilos sávban lévő lokalizált nívóinak egyikénél. A 3,6 eV-nál megfigyelhető lokális maximum az N4 optikai sáv, amely az N3 centrumhoz kapcsolódó optikai átmenet [55]. Az N4 optikai átmenet a centrumban a nitrogénen lokalizált $e$ pályáról elektron feljuttatását jelenti egy a vezetési sávhoz közel lévő sekély csapda nívóra, 
ami a vakancián kívül lokalizált $a_{1}^{*}$ pálya és egy újabb bizonyítéka a kialakított N3 hibahelyszerkezetnek.

Az emissziós intenzitás újból növekszik $\sim 3,75$ eV-nál nagyobb fotonenergiáknál. Az optikai abszorpciós spektrumban [52] ennél a fotonenergiánál megfigyelhető növekedést „második abszorpciós élnek" nevezik és a szennyező nitrogének $A$ aggregátumával hozzák kapcsolatba. Ez a szennyezési centrum tulajdonképpen szubsztitúciós nitrogén párokból áll (bővebben a 3.2. részben). Az N3 centrum emissziójának gerjesztése energiatranszfer útján lehetséges. Két molekuláris centrum közötti energiatranszfer a jól ismert Förster mechanizmusok révén lehetséges [141].

A nanogyémántban kialakított lumineszcencia centrum gerjesztési spektrumának alapvető jellemzői megegyeznek az N3 centrum irodalomban publikált gerjesztési spektrumával. A kialakított centrum lokális környezetének relaxációjában mutatkozó eltéréseknek az oka, hogy a gerjesztési spektrum fonon oldalsávjában nem minden struktúra jelentkezik karakterisztikusan a nanogyémántban. Az extra gerjesztést okozó szubsztitúciós nitrogén párokhoz kapcsolódó centrum kialakulása pedig lehetséges a FIB módszerrel a nanogyémántba implantált $N_{2}^{+}$ionok jelentős mennyisége miatt.

\section{Összefoglaló:}

A dolgozatnak ebben a fejezetében bemutattam, hogy mérsékelt ionenergiák (2-30 keV) és iondózisok $\left(1,5 \times 10^{15}-4,5 \times 10^{15}\right)$ alkalmazása mellett viszonylag egyszerü és széles körben elérhetö PIII és FIB implantációs technikákkal, valamint komplex hökezelés utólagos alkalmazásával a mélykék hullámhossztartományban, szobahömérsékleten is intenzíven emittáló szennyezési centrumot lehet kialakitani $\sim 12 \mathrm{~nm}$ átlagos szemcsemérettel rendelkezö, robbantásos módszerrel készült nanogyémánt kristályokban.

A gyémánt nanoszemcsék környezetében, a rácsstruktúrában az implantálás hatására bekövetkezö változásokat Raman-spektroszkópiai módszerrel vizsgálva megmutattam, hogy a roncsolódás során kialakult nem gyémánt kötések döntően $s^{2}$ hibridizációjú szénatomokat tartalmazó gyürüs és láncos struktúrák. A nagyobb ionenergiánál és fluxusoknál föként grafitos rendezödést mutató nanofragmensek kialakulása jellemzö. A kisebb ionenergia és fluxus kedvez az sp kötéseket tartalmazó láncszerü szerkezeti elrendezések kialakulásának. A $450{ }^{\circ}$ C-on, levegön végzett hökezelés eloxidálja az $\mathrm{sp}^{2}$ kötéseket tartalmazó szerkezetek jelentős hányadát. A gyémántrácsnak az implantáció okozta roncsolódását a gyémánt karakterisztikus Raman-szórási csúcsának $\left(\sim 1332 \mathrm{~cm}^{-1}\right)$ kiszélesedése mutatja. A különbözö hibahelyek, szennyezési centrumok kialakulására az 1230 és $\sim 1280 \mathrm{~cm}^{-1}$ körüli hullámszámoknál megjelenö széles szórási sávokból lehet következtetni.

Az implantált nanogyémánt lumineszcencia spektrumainak részletes vizsgálatával megmutattam, hogy a kialakitott, nitrogént tartalmazó komplex hibahely az N3 centrum. A 
lumineszcencia spektrum illesztéssel meghatározott zérusfonon vonalának csúcspozíciója 2,985 eV, míg kiszélesedése 68-75 meV között változik. A nagy spektrális vonalszélesség inhomogén kiszélesedéssel függ össze, amit az N3 centrumok lokális környezetének különbözö mértékü relaxációja magyaráz.

A $8 \mathrm{~K}$ hömérsékleten meghatározott lumineszcencia spektrum fonon oldalsávjának részletes vizsgálata során megmutattam, hogy a kialakitott centrum vakanciát tartalmaz és a tömbi gyémántban vizsgált N3 centrumra jellemzö fononszerkezetek rezgési energiáival jó egyezést mutat. Az implantált nanogyémántban 8 K hömérsékleten mért gerjesztési spektrum alapvetö jellemzöi megegyeznek a tömbi gyémántban vizsgált N3 centrum gerjesztési spektrumával. A 3,6 eV körül jelentkezö lokális maximum az N3 hibahelyszerkezethez tartozó N4 optikai átmenete. A nanogyémántban kialakitott komplex szennyezési centrum elektronnívói a tilos sávban lévö lokalizált állapotok és a legkisebb energiájú gerjesztett állapot 0,4 eV-ra található a vezetési sáv aljától. A 3,75 eV gerjesztő fotonenergiától az emissziós intenzitás újbóli növekedése a szubsztitúciós helyen lévö, nitrogén párok által létrehozott szennyezési centrum optikai abszorpciójával és az N3 centrumnak energiatranszfer útján történö gerjesztésével magyarázható. 


\subsection{A SiV centrum}

A gyémántrácsban kialakított $\mathrm{SiV}$ szennyezési centrum fénykibocsátása az alkalmazási lehetőségek széles spektrumát tárja elénk. A centrum egyfoton emitterként való alkalmazásához elkerülhetetlen, hogy mindegyik $S i V$ centrum ugyanazokkal a spektrális paraméterekkel rendelkezzen. Az irodalmi eredményekkel foglalkozó fejezetben már részleteztem, hogy mekkora a szórás mind a zérusfonon vonal csúcshelyzetében, mind pedig a kiszélesedésben a különböző laboratóriumok által publikált eredmények között [77, 88, 142]. Általános magyarázatként a SiV centrumok környezetében kialakuló eltérő lokális feszültségeket említik a különböző szerzők. Ennek a javaslatnak a szisztematikus kísérletsorozatokkal történő alátámasztására eddig még nem került sor. A SiV centrum zérusfonon vonalának gyakran megfigyelt aszimmetrikus alakja ugyancsak nem előnyös tulajdonság a gyakorlati alkalmazás szemszögéből. Ezekhez a problémákhoz kapcsolódóan célként tüztem ki, hogy kutatásaim során megpróbálom szisztematikusan változtatni a $\operatorname{SiV}$ centrum kialakításának paramétereit. Ennek hátterét és körülményeit már részletesen tárgyaltam a kísérleti résszel foglalkozó fejezetben, most pedig az elvégzett vizsgálatok eredményeinek a bemutatására és azok diszkussziójára kerül sor.

\subsubsection{A $S i V$ centrum lumineszcencia spektruma nanogyémánt vékonyrétegekben}

A különböző paraméterek mellett nanogyémánt vékonyrétegekben kialakított SiV defektcentrumokat fotolumineszcencia spektroszkópiai módszerrel vizsgáltam. A 6.14. ábrán néhány reprezentáns emissziós spektrumot mutatok be, amelyeket szobahőmérsékleten 2,54 eV (488 nm) gerjesztéssel mértem. A spektrumsorozat jól demonstrálja, hogy mind a ZPL csúcshelyzete, mind pedig annak kiszélesedése mintáról mintára némileg változik. Szemmel látható a fonon oldalsáv módosulása is. Érdemes még megfigyelni néhány mintánál, hogy a ZPL a kis energiájú oldalon aszimmetrikussá válik. A spektrumok részletes elemzésére a későbbiekben kerül sor.

Ahhoz, hogy a SiV centrum lumineszcenciájának a 6.14. ábrán bemutatott változásait ténylegesen a nanogyémánt preparálási paramétereivel, illetve a nanogyémánt más fizikai jellemzőivel összefüggésbe lehessen hozni, tudnunk kell, hogy egy adott paraméter-együttes mellett preparált nanogyémántban mekkora a szórása a SiV centrumok emissziós tulajdonságainak. Ennek meghatározására a nanogyémánt vékonyrétegeken egy $10 \times 10 \mu \mathrm{m}^{2}$-os felületet pásztázva mértem a lumineszcencia spektrumokat, majd térképet készítettem a $S i V$ centrum emissziós csúcshelyzetének és félértékszélességének változásáról. Mivel a gerjesztésre használt lézer $1 \mu \mathrm{m}$ átmérőjű foltot világít meg, így $2 \mu \mathrm{m}$ lépésközt választottam, hogy a mintavételezési területek ne fedjenek át egymással. 


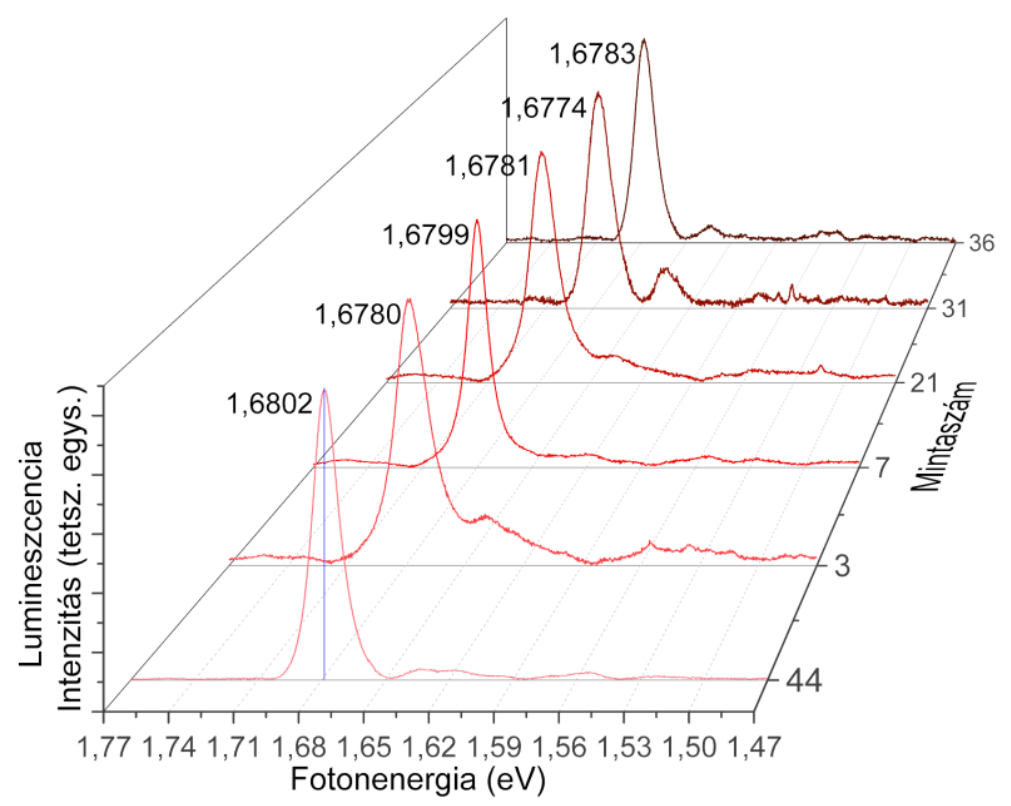

6.14. ábra: A különbözö paraméterek mellett elöállitott nanogyémánt vékonyrétegekben lévő SiV centrumok 2,54 eV (488 nm) fotonenergiával gerjesztett lumineszcencia spektrumai szobahömérsékleten.

A 6.15. és 6.16. ábrákon tipikus példaként mutatom be a különböző textúrával rendelkező nanogyémánt vékonyrétegekben a SiV centrum emissziójára kapott eredményeket. Megjegyzem csupán, hogy a SiV centrum ZPL-jének csúcspozíciójánál a mérőrendszerünk feloldóképessége 0,25 meV. Mindkét ábrán jól látható, hogy a nanogyémánt vékonyrétegeken belül a vizsgált spektrális paraméterek változása csak nagyon kis tartományon belül mozog. Míg a kis átlagos szemcseméretü, karfiolos textúrájú nanogyémántban a ZPL csúcspozíciója 1,6799-1,6808 eV között változik (6.15. ábra), addig a nagyobb átlagos szemcseméretü, több kifejlett kristályfelülettel rendelkező nanogyémánt rétegnél a ZPL csúcspozíciója 1,6780-1,6788 eV tartományba esik (6.16. ábra). A félértékszélesség a kisebb átlagos szemcséjű nanogyémántban 8,1-8,9 meV között változott, míg a nagyobb átlagos szemcseméretünél 16,1-16,9 meV közötti értékek voltak mérhetők. A csúcspozícióban és a félértékszélességben tapasztalt $\sim 0,8 \mathrm{meV}$ szórás egy nanogyémánt rétegen belül kis értéknek számít az irodalmi eredményekhez képest. Főleg a csúcspozíció esetében számolnak be egyedi centrumoknál több mint egy nagyságrenddel nagyobb szórásról [90]. Ebből kifolyólag a fenti vizsgálatokból megállapítható, hogy a $S i V$ centrum zérusfonon vonalának spektrális paraméterei egy adott mintára jellemzőek, a tapasztalt nagyon kismértékü szórás pedig a centrumok nem teljesen egyformán relaxált környezetével lehet kapcsolatban. 

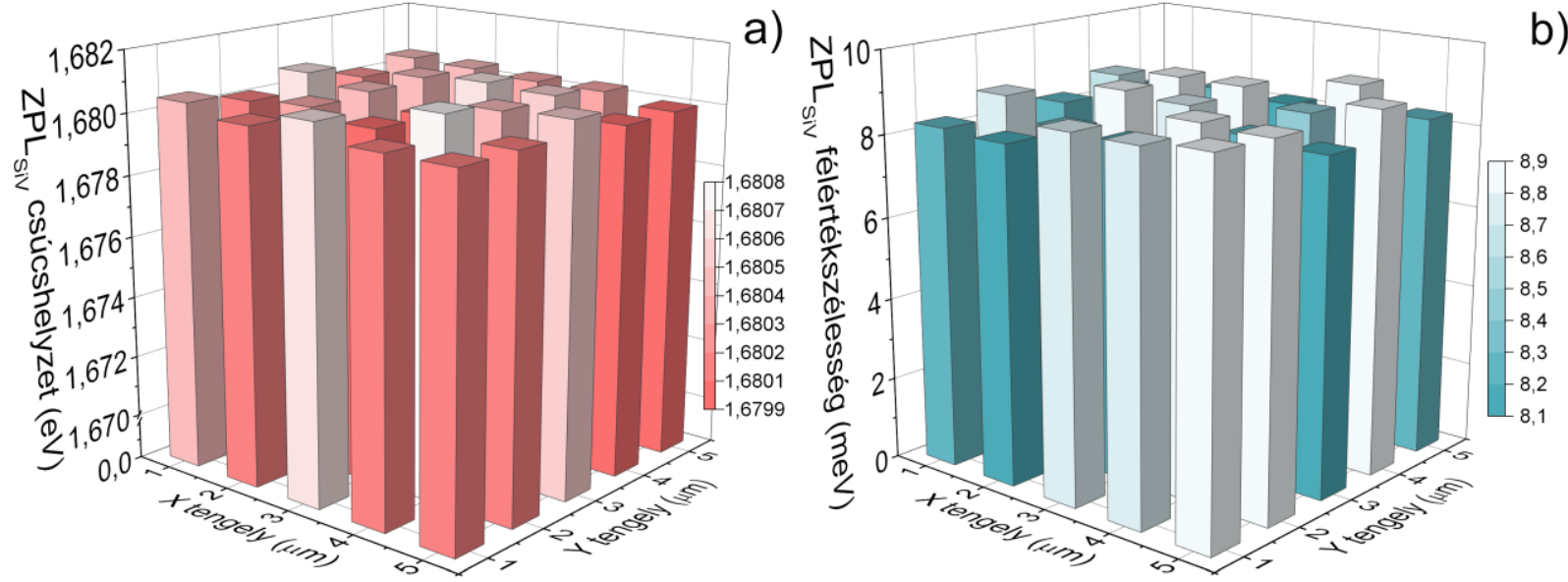

6.15. ábra: A SiV optikai centrum lumineszcencia spektrumában a ZPL csúcshelyzetének (a) és félértékszélességének (b) változása a $750{ }^{\circ} \mathrm{C}$ hordozóhömérsékleten és 3\% $\mathrm{CH}_{4}$ tartalom mellett leválasztott vékonyréteg (CRRP7) esetében. A réteg átlagos szemcsemérete 29,4 nm.

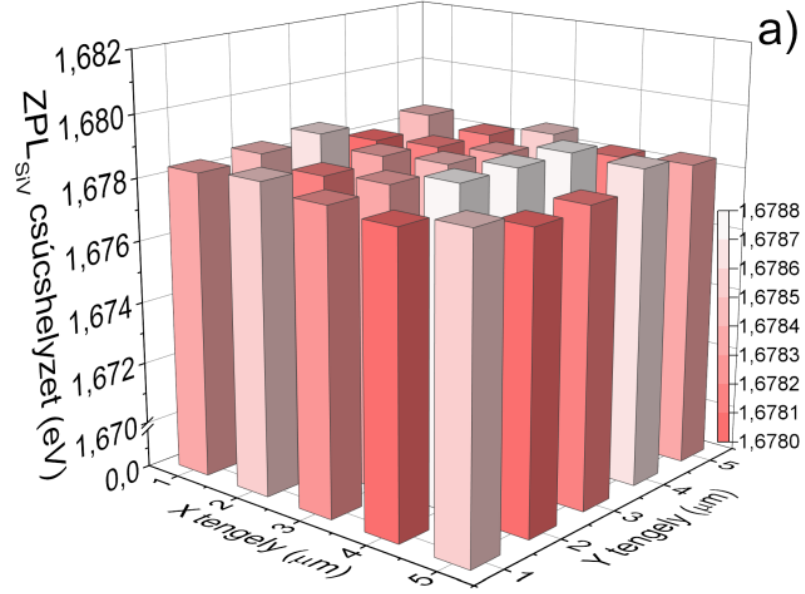

a)

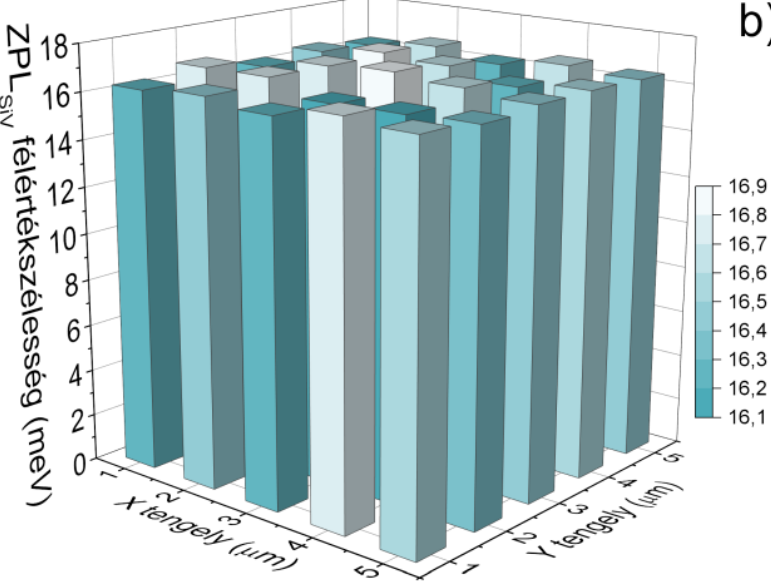

6.16. ábra: A SiV optikai centrum lumineszcencia spektrumában a ZPL csúcshelyzetének (a) és félértékszélességének (b) változása a $750{ }^{\circ} \mathrm{C}$ hordozóhömérsékleten és 0,5\% $\mathrm{CH}_{4}$ tartalom mellett leválasztott vékonyréteg (CRRP3) esetében. A réteg átlagos szemcsemérete 108,8 nm.

\subsubsection{A centrum zérusfonon vonalának (ZPL) spektrális eloszlása}

A nanogyémánt vékonyrétegekben kialakított $S i V$ centrum emissziójának vizsgálata során gyakran tapasztaltuk a ZPL aszimmetrikus kiszélesedését, amit már mások is megfigyeltek korábban [91]. Az aszimmetria minden esetben az emissziós sáv kisenergiájú oldalán jelentkezik és mértéke változik a különböző mintákban. Ez jelentősen rontja a centrum egyfoton emitterként való alkalmazásának lehetőségeit, ugyanakkor korlátozza a spektrális paraméterek pontos meghatározását is, így fizikai hátterének felderítése mindenképp indokolt.

Bár a SiV ZPL aszimmetrikus kiszélesedését többen megfigyelték [91, 6], annak magyarázatára eddig nem született meggyőző kísérleti eredmény. E. Neu [6] szerint az aszimmetria oka a 
polikristályos CVD rétegen belüli belső feszültség eltérések, amelyek a színcentrum-együttesen belüli egyes centrumok csúcshelyzetének egyenlőtlen eloszlását, illetve a centrumok ZPL-jeinek inhomogén kiszélesedését okozzák. Azt, hogy az egyes csúcspozíciókra miért kizárólag csak a vörös eltolódás a jellemző, nem részletezi. Azonban ami a leginkább kétségbe vonja a magyarázatot, az az egyetlen centrum esetében bemutatott szobahőmérsékletű lumineszcencia spektrum, melyre jól látható módon nem teljesen illik a szimmetrikus görbe [6. irodalom, 127. oldal].

A SiV centrum ZPL-jének aszimmetriájára az egyik lehetséges magyarázat egy másik centrum emissziója, mely atomi szerkezete ugyan eltér a $S i V$-től, azonban ZPL vonala ahhoz nagyon közel esik. Ahogyan azt már a 3.3.3.1. alrészben részleteztem, a GRl centrumot - melynek ZPL-je 1,673 eV-nál található - mint az aszimmetriáért felelős hibahelyet elvetették a lehetőségek közül [91]. Véleményünk szerint azonban érdemes ezzel a centrummal kapcsolatosan további vizsgálatokat végezni. Mivel a GRl centrum természeténél fogva elsősorban a felület közelében, a nagyobb méretü, kiterjedtebb kristályfelülettel rendelkező szemcsékben alakul ki [1], legalábbis a mikrokristályos CVD rétegeket illetően, ezért eltérő szemcsemérettel rendelkező nanogyémánt vékonyrétegekben vizsgáltuk az 1,68 eV környéki emissziós sáv alakját, különböző fotonenergiájú lézeres gerjesztést alkalmazva.
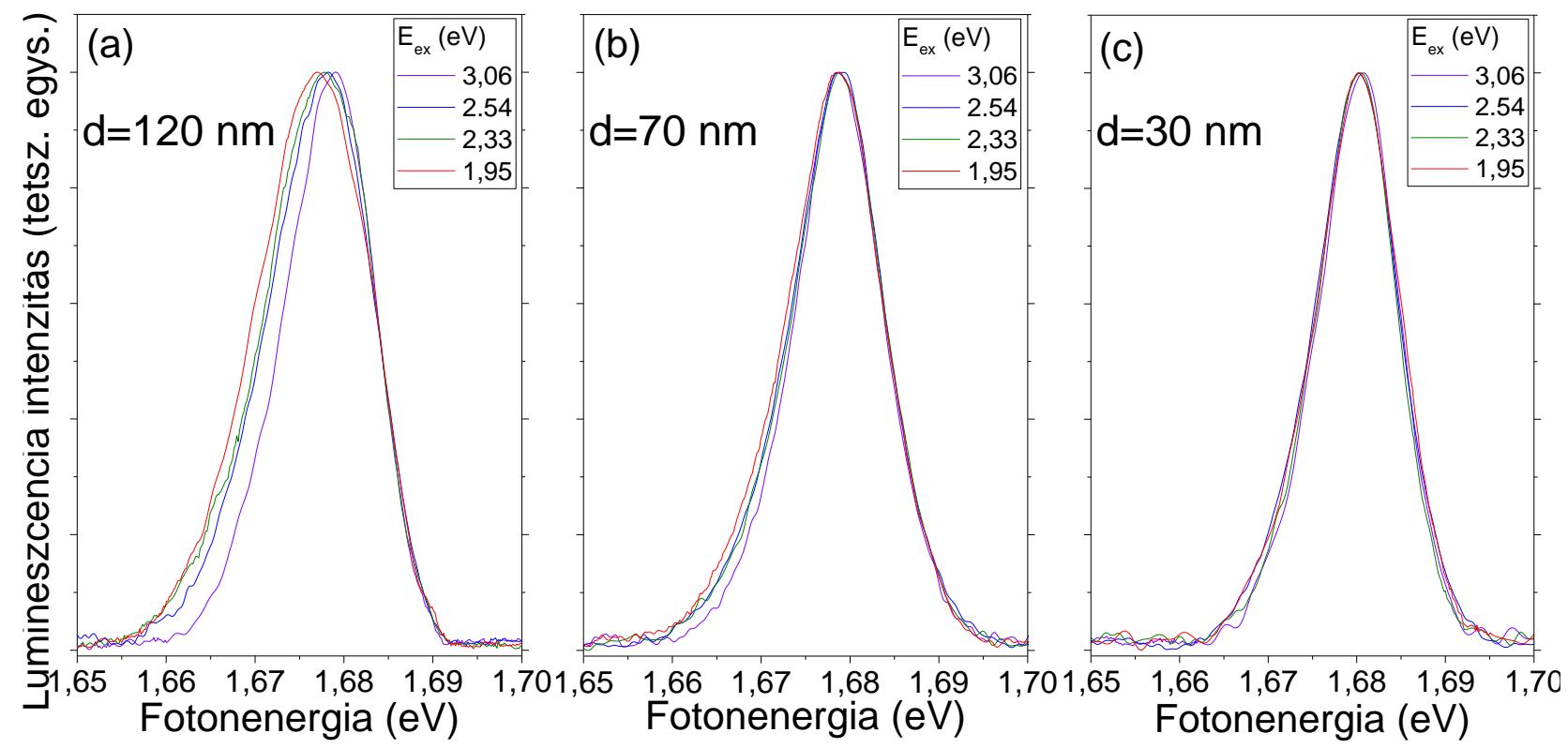

6.17. ábra: A 120 (a), 70 (b) és $30 \mathrm{~nm}$ (c) átlagos szemcseméretü nanogyémánt vékonyrétegekben a SiV centrum lumineszcencia spektrumában a ZPL (1,68 eV) alakjának változása a különbözö fotonenergiájú lézeres gerjesztés hatására. A spektrumok felvétele minden egyes gerjesztés során ugyanabban a pozicióban, szobahömérsékleten történt.

A 6.17. ábrán az 1,68 eV-os emissziós sáv alakjának a változását mutatom be a különböző fotonenergiájú lézeres gerjesztések hatására három különböző átlagos szemcseméretű nanogyémánt rétegen. Jól látható, főleg a két nagyobb szemcseméretü minta esetében, hogy a gerjesztő energia 
változásával a spektrum alakja változik. A változás elsősorban a sáv kiszélesedésében mutatkozik meg, amit az emissziós sáv kisenergiájú oldalán tapasztalható intenzitásnövekedés okoz. A legnagyobb változás a $120 \mathrm{~nm}$ átlagos szemcseméretű nanogyémánt rétegben figyelhető meg 1,95 eV-os gerjesztés mellett. Ennél a mintánál a gerjesztő energia csökkentése a csúcspozíció jelentős vörös eltolódását is okozza. Az átlagos szemcseméret csökkenésével mind a kisenergiájú oldalon tapasztalt változás, mind pedig az aszimmetria mértéke csökken, azonban a ZPL spektrumok nagyenergiájú oldala egyik esetben sem változik.

Ezen eredmények összhangban vannak azzal a feltételezéssel, hogy a SiV ZPL vonalalakjának aszimmetriáját egy másik centrum emissziója okozza. A nagyobb átlagos szemcseméretü nanogyémántban a $G R 1$ centrumok könnyebben tudnak kialakulni, mivel preferálják az $\{111\}$ síkot [103], ezért ezekben a mintákban a gerjesztő energia csökkenésével jelentősebbé válik az aszimmetria, azaz a GRl centrumok hozzájárulása az 1,68 eV-os emissziós sávhoz.

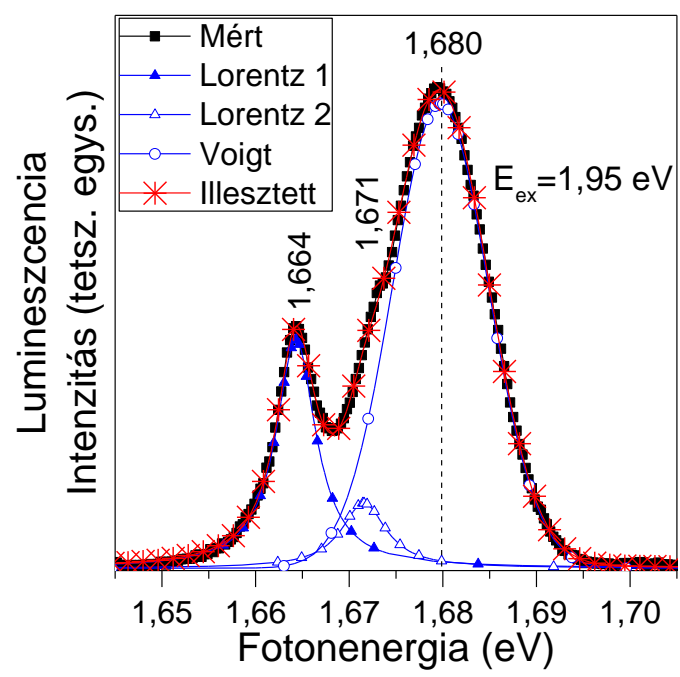

6.18. ábra: A $120 \mathrm{~nm}$ átlagos szemcseméretü nanogyémánt vékonyréteg nagy GR1 koncentrációjú területen 1,95 eV lézeres gerjesztéssel, szobahömérsékleten mért lumineszcencia spektruma. A spektrum dekompozíciója egy Voigt és két Lorentz görbével történt a különbözö lumineszcencia centrumok csúcspozícióinak meghatározása céljából.

A fentiekben részletezett feltételezés további megerősítése az a kísérleti eredmény, melyet a nagyobb szemcseméretű nanogyémánt vékonyrétegekben lévő GRl centrum emissziós maximumhelyére $(1,673 \mathrm{eV})$ optimalizált pásztázó mérések során kaptam 1,95 eV-os gerjesztéssel. Az így mért lumineszcencia spektrumot a 6.18. ábrán adom meg. A spektrum két jól elkülönülő emissziós sávból áll, melyek közül a relatíve szélesebb maximumhelye 1,680 eV-nál található, míg a keskenyebb 1,664 eV-nál jelentkezik. Utóbbi a vállként 1,671 eV-nál jelentkező emissziós sávval alkotja a GRI centrum dupla komponensü zérusfonon vonalát, míg az 1,680 eV-os sáv a SiV centrumhoz rendelhető. A GR1 ZPL-jének felhasadását, mely gyakran megfigyehető a CVD módszerrel előállított gyémánt 
rétegekben a jelentős mértékü lokális belső feszültség okozza [1], mely a mi esetünkben is helytálló. A tapasztalt vörös eltolódás mindkét centrum esetében nagy valószínűséggel szintén a mintában jelenlévő feszültséggel függ össze.

\subsubsection{A ZPL spektrális paramétereinek meghatározása}

A nanogyémánt vékonyrétegekben különböző preparációs feltételek mellett kialakított $S i V$ szennyezési centrum lumineszcencia tulajdonságainak összehasonlítása céljából a ZPL spektrális paramétereit, így a csúcspozíciót, a félértékszélességet, valamint a DW, vagy HR faktorokat illesztéssel határoztam meg. A 6.19. ábrán egy példát mutatok be arról, hogy hogyan határoztam meg a „nyers” kísérleti eredményből a megfelelő spektrális jellemzőket.
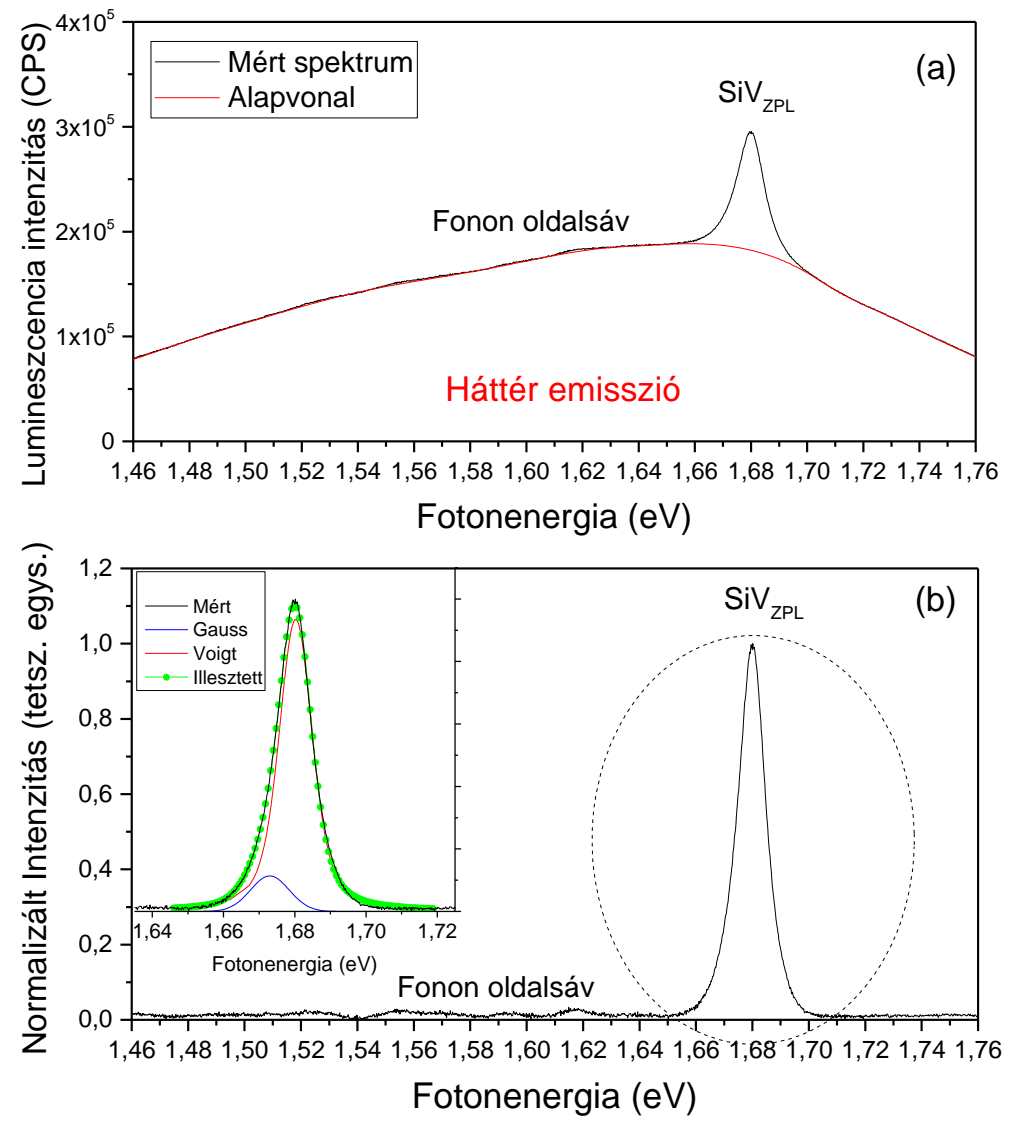

6.19. ábra: A SiV centrum spektrális tulajdonságainak meghatározása céljából végzett alapvonal korrekció (a) és a ZPL Voigt és Gauss görbével történö illesztése (b).

A nanogyémánt vékonyrétegekben kialakított $\operatorname{SiV}$ centrumok gerjesztésére $2,54 \mathrm{eV}$ fotonenergiát használtam, ami más szerkezeti hibák, szennyezési centrumok lumineszcenciáját is gerjesztheti, amelyek így háttér emisszióként megjelenhetnek a mért spektrumban. A vizsgált nagyszámú minta többségében ilyen háttér emissziót tapasztalhatunk, melyek intenzitása változik, így megnehezíti az illesztést, ezért a mért lumineszcencia spektrumokon minden esetben alapvonal 
korrekciót kellett végezni. Ennek során $8 \mathrm{db}$ rögzített pontot (anchor points) alkalmaztam az alapvonal meghatározására, melyeket „spline” görbével kötöttem össze. Az alapvonal korrigált spektrum lehetővé tette a zérusfonon vonal illesztését és a fonon oldalsáv, valamint a ZPL relatív intenzitásának a meghatározását a vizsgált nanogyémánt vékonyrétegekben. Az illesztés eredményeit ezután fel lehetett használni az elektron-fonon csatolás vizsgálata szempontjából lényeges DW faktor meghatározására.

Az alapvonal korrekciót követően az 1,68 eV környékén jelentkező aszimmetrikus emissziós sávot 2 görbével illesztettem. A SiV centrum spektrális paramétereinek meghatározása céljából Voigt görbét használtam, míg a kis energiájú oldalon jelentkező aszimmetriát okozó GRl centrum emisszióját Gauss görbével kompenzáltam, melyet az előző részben kapott kísérleti eredmények indokoltak. Az említett görbék alkalmazhatóságát az illesztés jósága ( $\chi^{2}$ paraméter) is megerősítette, mely minden esetben meghaladta a 0,998-es értéket. A Voigt görbe jó illeszkedése mellett annak fizikai háttere is megalapozott. Stoneham [143] részletesen foglalkozott a belső feszültség okozta spektrális vonalkiszélesedés elméleti vizsgálatával. Ennek lényege, hogy ha a kristályban a belső feszültség az egyenletesen eloszló ponthibáktól származik, akkor a lumineszcencia vonalalak Lorentz, ha viszont a belső feszültség forrása diszlokációkhoz köthető, akkor a vonalak Gauss görbe alakú lesz. Abban az esetben, ha mindkét típusú hibahely megtalálható a szerkezetben, ahogy ez a nanogyémánt vékonyrétegekben is igaz, akkor az emissziós vonalalak az említett két görbe konvolúciója lesz, ami a Voigt profil [143].

\subsubsection{A spektrális paraméterek változásának vizsgálata}

A 6.2.2 és 6.2.3 alfejezetekben részletezett vonalalak aszimmetriát és illesztési folyamatot figyelembe véve elvégeztem a ZPL spektrális paramétereinek meghatározását a különböző paraméteregyüttesek mellett kialakított $S i V$ centrumokra. Az illesztés eredményeit és azok hibahatárát a dolgozat végén található 12.3. függelékben foglalom össze. Mielőtt azonban részletesen foglalkoznék a paraméterek változásával, érdemes felidézni a pásztázással meghatározott ZPL paraméterek szórását egy mintán belül (a csúcspozíció és a félértékszélesség is $\sim 0,8 \mathrm{meV}$ értékkel változott egy $10 \times 10 \mu \mathrm{m}^{2}$ tartományban).

Az illesztések alapján a nanogyémántban a SiV centrumok ZPL-jének csúcspozíciója 1,6772 és 1,6808 eV között változik, míg a félértékszélessége 6,5 és 18,1 meV között. A teljes mintasorozaton a csúcspozícióban kapott 3,6 meV-os változás több mint négyszeres, míg a kiszélesedésben tapasztalt közel 12 meV-os változás legalább 1 nagyságrenddel nagyobb, mint amit egyetlen mintán belül kaptunk. Ebből arra a következtetésre lehet jutni, hogy a különböző preparálási körülmények megváltoztatják a SiV centrum ZPL-jének spektrális paramétereit. Itt csupán megjegyeznénk, hogy az 
általunk mért vonalkiszélesedés kisebb, mint amit más szerzők SiV centrum-együttesekre (több centrumot mérnek egyszerre) kaptak és több esetben egyedi centrumokéval összemérhető [77, 80, 84].

Abból a célból, hogy közelebb jussunk a változások fizikai hátterének megértéséhez érdemes megnézni, hogy van-e korreláció a csúcspozíció és a félértékszélesség változása között. A 6.20. ábra a ZPL csúcspozícióját ábrázolja a félértékszélesség függvényében.

Jól látható, hogy a félértékszélesség változása korrelációt mutat a csúcspozíció változásával, mely arra is utal, hogy a kísérleti eredmények alapján meghatározott változása a csúcspozíciónak és a félértékszélességének ugyanarra a fizikai jelenségre vezethető vissza. Ebből a szempontból érdemes megvizsgálni a nanogyémántban kialakított $S i V$ centrumok környezetének a változását, melyet az eredő lokális belső feszültségváltozáshoz rendelhetünk, valamint a nanogyémánt vékonyréteg textúráját jellemző átlagos szemcseméretet is.

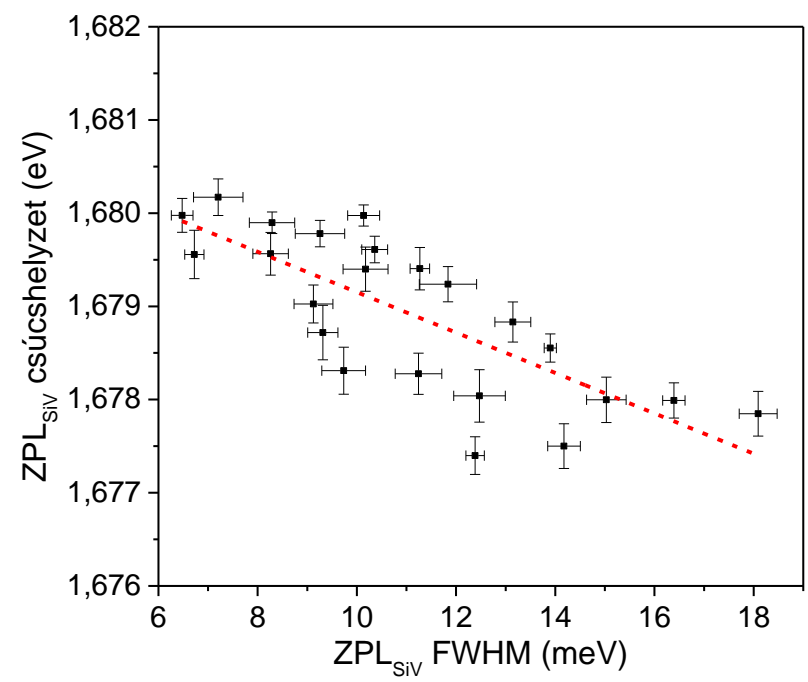

6.20. ábra: A különböző preparálási paraméterek mellett kialakitott SiV centrum zérusfonon vonalának illesztéssel meghatározott csúcshelyzete és félértékszélessége. A piros szaggatott vonal a legkisebb négyzetek módszerével meghatározott változási tendenciát jelöli.

Az egyedi $S i V$ centrumok környezetét jellemző lokális feszültséget közvetlenül mérni nem tudjuk, azonban a gyémánt Raman-szórási spektrumát ugyanabban a gerjesztett térfogatban meg tudjuk mérni, amely térfogatban a lumineszcencia jellemzőket is. A gyémánt Raman-szórási sávjából pedig meg lehet határozni a nanogyémánt vékonyréteg adott térfogatelemére jellemző belső feszültséget. Így lehetőség van arra, hogy kapcsolatot keressünk a ZPL spektrális paramétereinek változása és a belső feszültség változása között.

\subsubsection{A maradék belső feszültség meghatározása a gyémánt Raman-szórási sávjából}

A tökéletes, feszültségmentes gyémánt kristály Raman-szórási sávjának csúcspozíciója 1332,3 $\mathrm{cm}^{-1}$ hullámszámnál található, azonban a kialakult különböző belső feszültség hatására ez a 
csúcshelyzet a nagyobb, vagy a kisebb hullámszámok felé tolódhat [90, 144]. Ha a kisebb hullámszámok irányába tolódik, akkor húzó (tensile) feszültségről beszélünk, ellenkező esetben pedig nyomófeszültségröl (compressive). A gyémánt Raman-csúcshelyzetének $\Delta v$ eltolódása a $\sigma$ feszültség hatására a következő egyenlettel írható le [144, 90]:

$$
\Delta v=v-v_{0}=-\alpha \sigma,
$$

ahol $\alpha$ a nyomásegyüttható, $v$ a spektrumból meghatározott csúcshelyzet, $v_{0}$ pedig a természetes, feszültségmentes gyémánt egykristály Raman-csúcsának pozíciója. A belső feszültség meghatározásához használt (6.1) egyenletnél a természetes gyémánt egykristály Raman-szórási csúcshelyzetét $v_{0}=1332,3 \mathrm{~cm}^{-1}$-nek, a nyomásegyütthatót pedig $\alpha=1,9 \mathrm{~cm}^{-1} /$ GPa-nak vettem [144].

A nanogyémánt rétegben az eredő belső feszültség kialakulásának több oka is lehet, amelyek külön-külön, de akár együttesen is okozhatják a Raman-sáv eltolódását. Ezek közül a leggyakoribbak a hordozó és a gyémántréteg különböző hővezetési együtthatójából eredő feszültségkülönbségek, a hordozó és a gyémánt rácsállandójából eredő feszültségek, a felületi sp ${ }^{2}$ határréteg okozta feszültség, illetve magában a gyémánt szerkezetben lévő hibák (ponthibák és kristályhibák) által generált feszültség. Mivel a rétegen belül különböző eredetű feszültségek vannak jelen, ezért a gyémánt Ramancsúcsának az eltolódása csak az eredő belső feszültséget tükrözi és nem alkalmas arra, hogy a forrását, vagy irányát beazonosítsa. Azonban azonos térfogatot gerjesztve a Raman-spektrumból meghatározott eredő feszültség az ugyanabban a térfogatban lévő SiV centrumokra ható belső feszültséget tükrözi, így használható a mikrokörnyezet változásának jellemzésére és a spektrális paraméterekre gyakorolt hatásának a vizsgálatára.

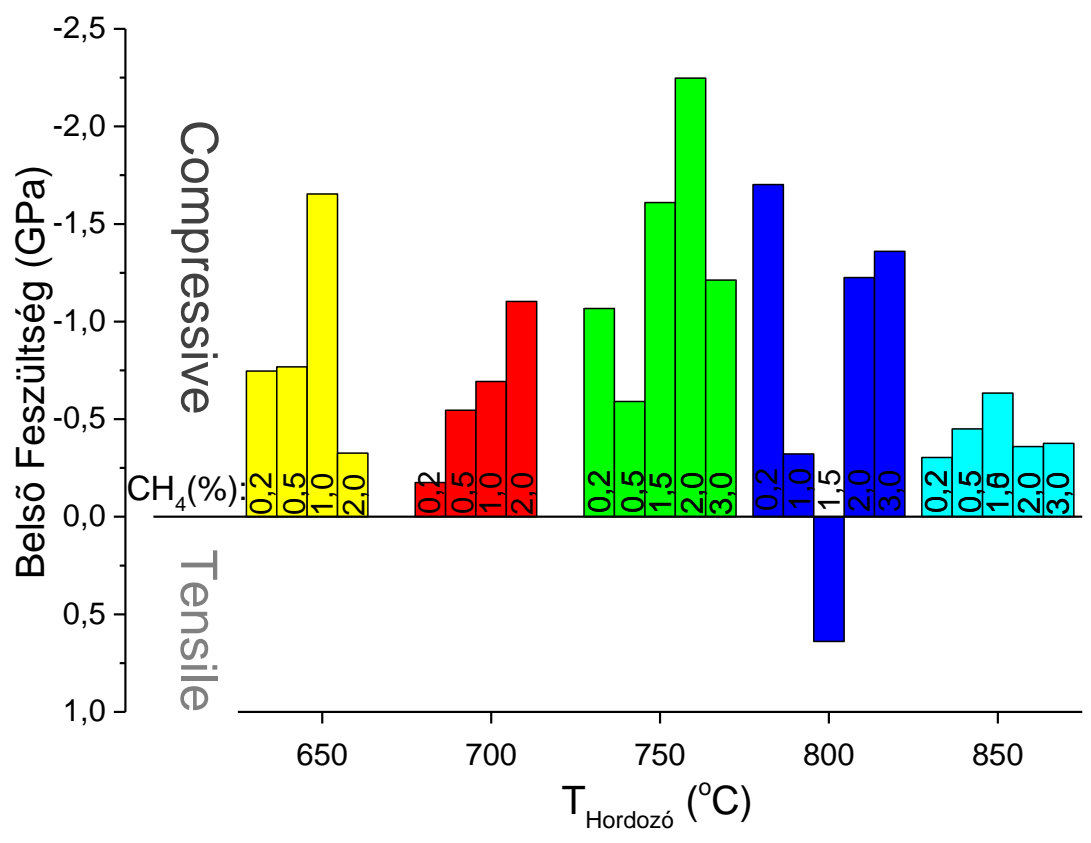

6.21. ábra: Az eredö belsö feszültség változása a különbözö hordozóhömérsékleten és metántartalomnál leválasztott minták esetében. 
A gyémánt Raman-szórási sávjából meghatározott belső feszültség értékei a különböző hordozóhőmérséklet alkalmazása mellett és eltérö $\mathrm{CH}_{4}$ tartalomnál leválasztott mintákra a 6.21. ábrán láthatóak. Az ábrán jól látható, hogy a mintákban a maradék belső feszültség viszonylag széles tartományon belül változik, és egy kivételével minden esetben nyomó típusú belső feszültség van jelen. A legnagyobb nyomófeszültséggel $(2,25 \mathrm{GPa})$ a $750{ }^{\circ} \mathrm{C}$-on és $1,5 \% \quad \mathrm{CH}_{4}$ koncentráció mellett leválasztott minta rendelkezik, míg a legkisebb nyomó feszültsége a $700{ }^{\circ} \mathrm{C}$-on $0,2 \% \quad \mathrm{CH}_{4}$ koncentrációnál leválasztott rétegnek van. A húzó feszültséggel rendelkező minta belső feszültsége $0,64 \mathrm{GPa}$.

Természetesen önmagában is fontos az a kísérleti eredmény, hogy a hordozóhőmérséklet és a forrásgáz metántartalma befolyásolja a nanogyémánt vékonyrétegben kialakult belső feszültséget, azonban jelenlegi kutatásaink szempontjából lényegesebb, hogy a feszültségváltozás és a $S i V$ centrumokra jellemző spektrális paraméterek változása között összefüggés van. Szintén lényeges, hogy ennek az összefüggésnek a vizsgálatát az a méréssorozat teszi lehetővé, mely során mind a feszültség meghatározáshoz használt Raman-spektrumot, mind pedig a $S i V$ spektrális paramétereinek meghatározásához használt lumineszcencia spektrumot egyidejüleg, a réteg azonos térfogatából veszem fel.

\subsubsection{A $S i V \mathrm{ZPL}$ spektrális paramétereinek változása a belső feszültséggel}

Miután meghatároztuk ugyanabban a mikrokörnyezetben a nanogyémánt réteg belső feszültségét és a $\mathrm{SiV}$ centrum zérusfonon vonalának spektrális paramétereit, nézzük meg, hogy milyen kapcsolat van ezen mennyiségek változása között. A 6.22. ábrán a SiV ZPL csúcspozíciójának és félértékszélességének a változása látható a nanogyémánt vékonyréteg eredő belső feszültségének függvényében. Annak ellenére, hogy a változás mértéke nem kiugró és az egyes mintákra meghatározott értékek jelentős szórást is mutatnak, mely a vizsgált térfogatban található egyedi centrumokra ható eltérő irányú és mértékủ nyomáskomponeneseknek tulajdonítható, a változás tendenciája elég jól beazonosítható az értékekre illesztett egyenes által (piros szaggatott vonal). Ennek alapján a csúcspozíció a nagyobb fotonenergiák felé tolódik el (kékeltolódás), míg a félértékszélesség csökken, amint a nanogyémántban az eredő belső feszültség egy kisebb értékű húzó feszültségről egyre nagyobb nyomófeszültséggé változik. A csúcspozíció 2,6 meV-os kékeltolódása a feltüntetett belső feszültség tartományban nem nagy érték ugyan, de meghaladja az egy mintára meghatározott szórás mértékét (zöld téglalappal jelölt tartomány a 6.22. ábrán). A tapasztalt kismértékü változás fontosságát talán leginkább a $\mathrm{SiV}$ centrum egyfoton emitterként való gyakorlati alkalmazása támasztja alá, amelynél az emittált fotonok megkülönböztethetetlensége alapfeltétel. Eredményeink ugyanakkor 
kísérletileg igazolják, hogy a lokális belső feszültség változása a $S i V$ centrum környezetében a ZPL maximum helyének szórását eredményezheti az egyedi centrumok szintjén is.
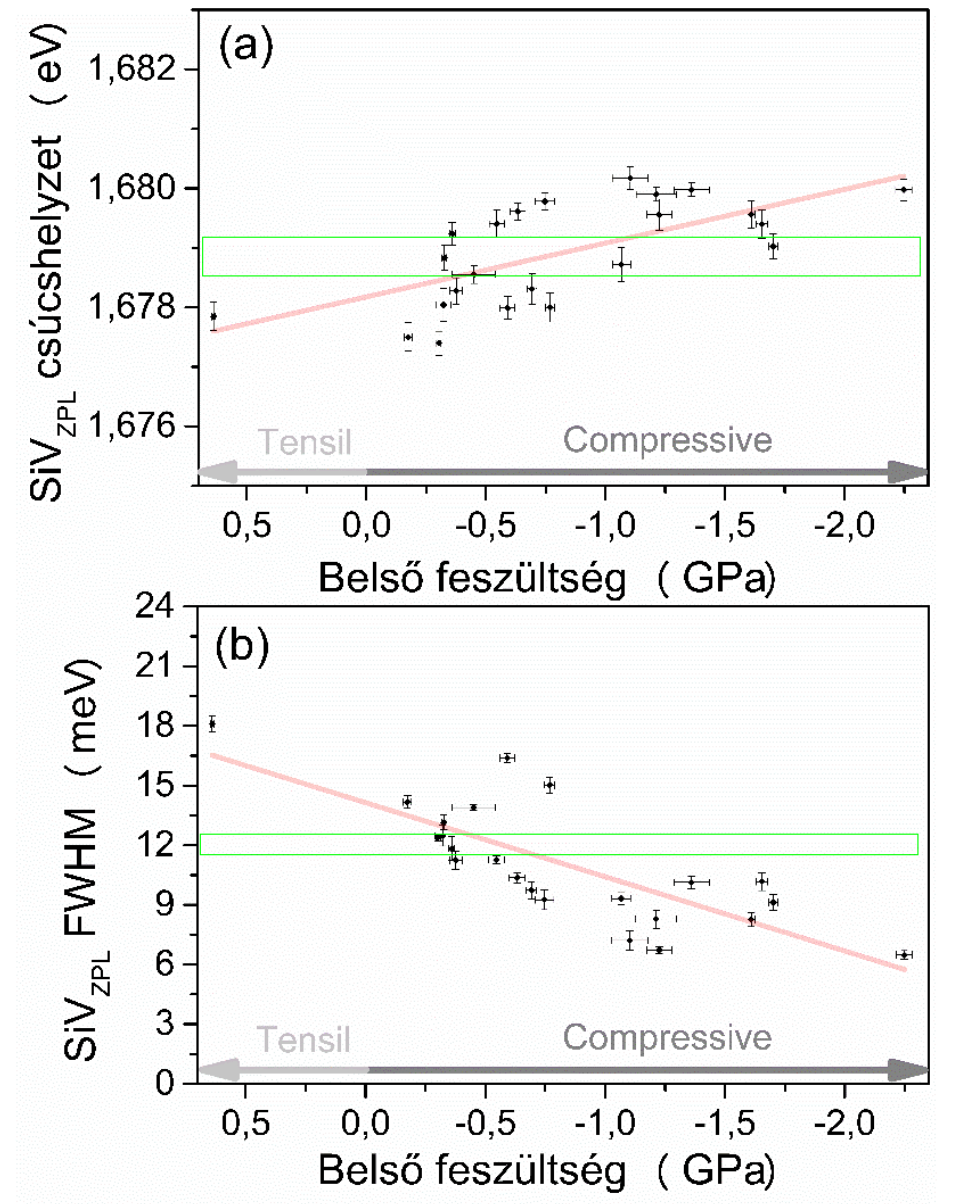

6.22. ábra: Az illesztéssel meghatározott SiV centrum ZPL (a) csúcspozíciójának és (b) félértékszélességének változása a lokális belső feszültség függvényében. Az illesztéssel meghatározott piros szinü egyenes a változás tendenciáját mutatja.

Szemben a ZPL csúcspozíció esetében tapasztalt kisebb mértékủ változással a lokális belső feszültség nagyobb hatással van a vonalkiszélesedésre. A húzó feszültségnél tapasztalt 18,1 meV-os kiszélesedés elég jelentősnek mondható, még a színcentrum-együttesekre vonatkozó korábbi eredményeket figyelembe véve is. Azonban az eredő nyomófeszültség növekedésével a vonalkiszélesedés drasztikusan csökken és a -2,25 GPa értéknél tapasztalt 6,4 meV-os ZPL félértékszélesség már az egyedi centrumra meghatározott értékeknél is kedvezőbb. Míg a nanogyémánt vékonyrétegeinkben a vonalkiszélesedés $6,4-18,1 \mathrm{meV}$ között változik, addig az egyedi centrumra meghatározott kiszélesedés szobahőmérsékleten 11,4 meV [84]. A ZPL csúcspozíciójának kísérletileg meghatározott kékeltolódása és félértékszélességének változása egymással kapcsolatban van, ahogyan ezt korábban már bemutattuk a 6.20. ábrán. A változás mögött lévő fizikai folyamatról pedig képet alkothatunk, ha megnézzük a SiV centrum energianívóit és a hozzá kapcsolódó elektron és fonon 
átmeneteket. A 6.23. ábrán a SiV centrum elektron energianívóit, valamint a különböző optikai és fonon átmeneteket adom meg a [146] irodalom alapján.

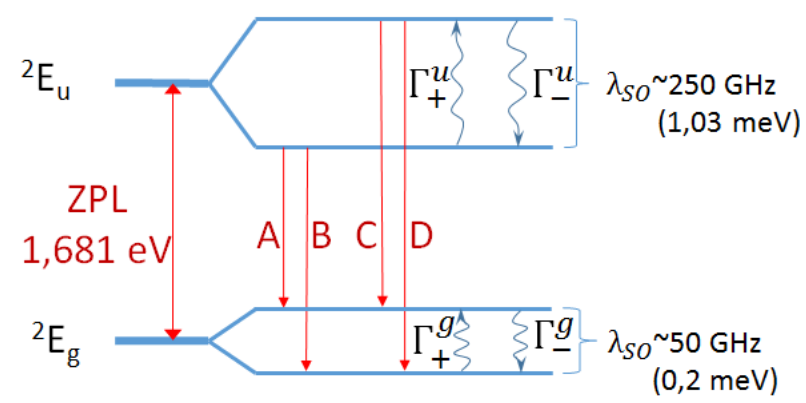

6.23. ábra: A SiV centrum elektron energianivói és sugárzó (egyenes vonal), valamint nem sugárzó (hullámos vonal) átmenetei. Az E szimmetriájú, kettős pálya degenerációt mutató ${ }^{2} E_{g}$ és ${ }^{2} E_{u}$ állapotok között van az optikai átmenet. Az ábrán nincs feltüntetve, de mindegyik szint spin 1/2 dublett. A spin-pálya kölcsönhatás részben megemeli a degeneranciát, elöidézve az alap és gerjesztett nívók dublett szerkezetét [145].

A sajátállapotok közötti optikai és fonon átmenetek spin megőrzőek és pálya szabadsági fokhoz kapcsolódnak. Az ZPL finomszerkezete (A, B, C és D átmenetek) $100 \mathrm{~K}$ felett nem látható. Az elektron-fonon folyamatok lineáris Jahn-Teller kölcsönhatás eredményei az E szimmetriájú elektronállapotok és az E szimmetriájú akusztikus fonon módusok között [146, 59]. Elsőrendü elektron-fonon átmenetek egyetlen, a felhasadással rezonáns frekvenciájú fonon elnyelésével, illetve emissziójával képes magyarázni a ZPL vonalkiszélesedésének hőmérsékletfüggését $20 \mathrm{~K}$ alatt. Magasabb hőmérsékleteknél másodrendü elektron-fonon átmenetek válnak dominánssá [146]. Az egyetlen, rezonáns fonon részvételével lejátszódó pálya-relaxációs folyamat sebességét a fonon állapotsűrűség és a spin-pálya felhasadás energiájánál lévő betöltöttségnek a kombinációja határozza meg. A nagy belső feszültségü terek megnövelik mind az alap, mint pedig a gerjesztett elektron állapotok felhasadását és ezáltal csökkentik a fonon állapotok betöltöttségét, ami a relaxációs folyamat visszaszorítását eredményezi [146]. Ez összhangban van azon kísérleti eredményünkkel, ami a ZPL csúcspozíciójának kékeltolódását mutatja a belső feszültség növekedésével. A megfigyelt 2,6 meV-os kékeltolódás azonban jelentősen meghaladja az 1,03 meV-nak megfelelő spin-pálya felhasadást. Ez arra utal, hogy más folyamatok is befolyásolják a ZPL csúcshelyzetét. Egy lehetséges magyarázat lehet a kvantum pöttyöknél és kvantum gödröknél, valamint nanohuzaloknál megfigyelt tilos sáv kiszélesedés, ami ezen anyagok szerkezeti sajátosságaival áll kapcsolatban [60, 61]. A nanoméret miatt ezen szerkezetek optikai tulajdonságai érzékenyebbek a szerkezeti hibákra, melyek torzíthatják a sávhatárokat. Ez a mi esetünkben azt jelenti, hogy a felhasadás következtében megnövekedett optikai átmenet energiáját a sávhatárok változása még inkább kiszélesítheti, ez pedig a kísérleteinkben 
tapasztalt kékeltolódáshoz vezethet. Az elektron-fonon kölcsönhatás révén végbemenő relaxációs folyamat visszaszorulása a nem sztatikus vonalkiszélesedést csökkenti. A ZPL sztatikus kiszélesedését a több, különböző lokális környezetben lévő centrum emissziójának a hozzájárulása okozza.

Magasabb hőmérsékleteknél (pl. szobahőmérsékleten) azonban a kétfononos folyamatok dominanciáját javasolták [146]. Azon feltételezés, hogy ez a kétfononos relaxációs folyamat visszaszorul, amint az alap és a gerjesztett állapotok felhasadása nő, ésszerünek tünik. Ezt a feltételezést alátámasztja a DW faktor növekedése, ami az elektron-fonon csatolás gyengülését mutatja.

\subsubsection{A SiV ZPL spektrális paramétereinek változása az átlagos szemcsemérettel}

Az előző pontokban azzal a kérdéskörrel foglalkoztam, hogy szisztematikusan változtatva a $\mathrm{SiV}$ centrum preparálási paramétereit, lehet-e kapcsolatot találni az emisszió ZPL-jének spektrális paramétereinek változása és a lokális környezet jellemzésére használt maradék belső feszültség között. Minthogy ezek a paraméterek különböző textúrájú, szemcseméretű és kötésszerkezetű nanogyémánt vékonyrétegeket eredményeztek, így több szempontból is fontos lehet megnézni, hogy változnak-e a SiV centrum emissziójának spektrális jellemzői a szemcsemérettel (a szemcseméret meghatározásával az 5.2.2. részben foglalkoztam). Mindemellett a szemcseméret a nanogyémánt réteg egészére jellemző tulajdonság, tehát nem lokális.
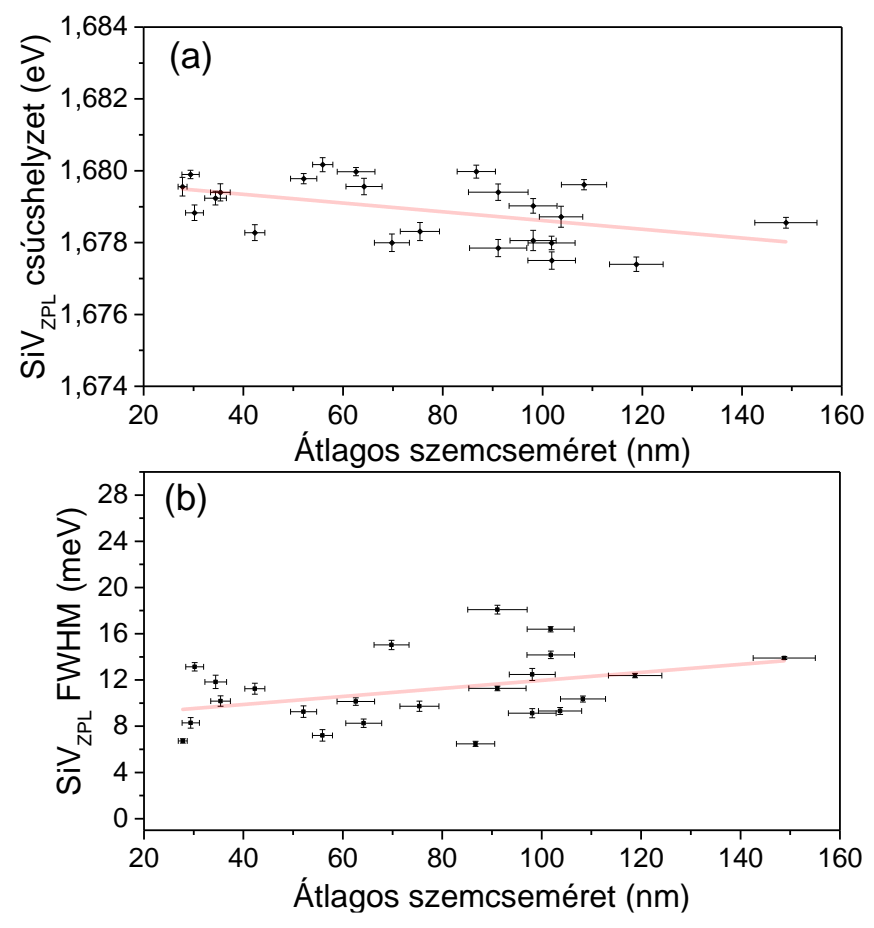

6.24. ábra: A SiV centrum ZPL-jének illesztéssel meghatározott spektrális paraméterei: (a) csúcspoziciója és (b) félértékszélessége a nanogyémánt réteg átlagos szemcseméretének a függvényében. Az illesztett piros egyenes a változás tendenciáját mutatja. 
A 6.24. ábrán a $S i V$ centrum ZPL-jének spektrális paramétereit ábrázoltam a rétegek átlagos szemcseméretének függvényében. Míg a szemcseméret csökkenése a csúcshelyzetet a nagyobb energiák felé tolja, addig a kisebb szemcséjü mintákban a vonalkiszélesedés csökkenő tendenciát mutat. A félértékszélesség változásának a mértéke azonban közel sem olyan látványos, mint a maradék belső feszültség változásakor. A nagyobb mértékü szórás valószínüleg azzal áll kapcsolatban, hogy az átlagos szemcseméret meghatározása egy eloszlási spektrumból történik, amelynek kiszélesedése változó. Ha nagy a kiszélesedés, vagyis eléggé különböző méretű nanokristályok találhatóak az adott rétegben, akkor könnyen előfordulhat, hogy a SiV centrumok nem az átlagos szemcseméretre jellemző környezetben vannak.

A tapasztalt $\operatorname{SiV}$ ZPL spektrális paraméterek szemcseméret függése összefüggésbe hozható az optikai gerjesztést követő relaxációs folyamatokban szerepet játszó fononok bezártságával. A legkisebb akusztikus fonon módus frekvenciája szemcseméret függő [146]. Az erős bezártság következtében a nanogyémánt szemcsék egyfajta fononikus tilos sávként viselkednek. A 120 nm-nél kisebb nanogyémánt szemcsékben korlátozva van azoknak a hullámoknak a terjedése, melyek frekvenciája kisebb 50 GHz-nél, míg a 40 nm-nél kisebb szemcsékben a $250 \mathrm{GHz}-n e ́ l$ nagyobb frekvenciák esetében. Mivel szinte a mintáink mindegyikénél a szemcseméret 27-120 (egy kivételével, amelynél $147 \mathrm{~nm}$ ) nm-es tartományba esik, ezért a relaxációs folyamat csökkenése az elektron-fonon kölcsönhatás miatt megjósolható [147].

\subsubsection{Elektron-fonon kölcsönhatás a $\mathrm{SiV}$ centrumnál}

\subsubsection{A Debye-Waller faktor}

Egy lumineszcencia centrum gyakorlati alkalmazhatósága nagyban függ attól, hogy az emittált fény egy széles spektrális eloszlást mutató rezgési oldalsávba koncentrálódik, vagy pedig egy kis kiszélesedésü, közel monokromatikus zérusfonon vonalba. Ezért fontos jellemzője a centrumnak az emittált fény megoszlása a ZPL és a rezgési oldalsáv között. Ennek jellemzésére használhatjuk a DW faktort, mely a ZPL intenzitásának aránya a centrum teljes intenzitásához. A 6.25.(a) ábra szemlélteti a $S i V$ centrum emisszióját és a DW faktor meghatározási módját.

A DW faktor az adott lumineszcencia centrumra jellemző mennyiség, azonban várhatóan az értéke különböző lesz, ha az adott $S i V$ centrum lokális környezete változik. Ennek megfelelően valamennyi nanogyémánt vékonyrétegben, amelyeknél a SiV centrumok különböző preparálási körülmények között lettek kialakítva, meghatároztuk a DW faktort és ezeknek a statisztikáját mutatom be a 6.25.(b) ábrán. A mintáinkban a DW faktor 0,623 és 0,875 között változik, azonban a legtöbb esetben a 0,75-0,8 tartományba esik, ami azt jelenti, hogy átlagosan a centrum emissziójának 74 \%-a 
a ZPL-ben koncentrálódik. Ez némileg jobb értéket jelent az irodalomban található 70\%-nál [90]. A DW faktor értékeinek változása a rétegekben arra enged következtetni, hogy változik az elektron-fonon csatolás mértéke. Mivel korábban már láttuk, hogy a SiV centrum ZPL-jének spektrális paraméterei függnek a lokális környezet jellemzésére használt maradék belső feszültségtől és változnak a nanogyémánt rétegek textúráját jellemző átlagos szemcsemérettel, ezért érdemes megvizsgálni a DW faktor változását ezen paraméterek függvényében, mivel azok a centrumok lokális és kiterjedtebb környezetét, illetve azok változását mutatják.
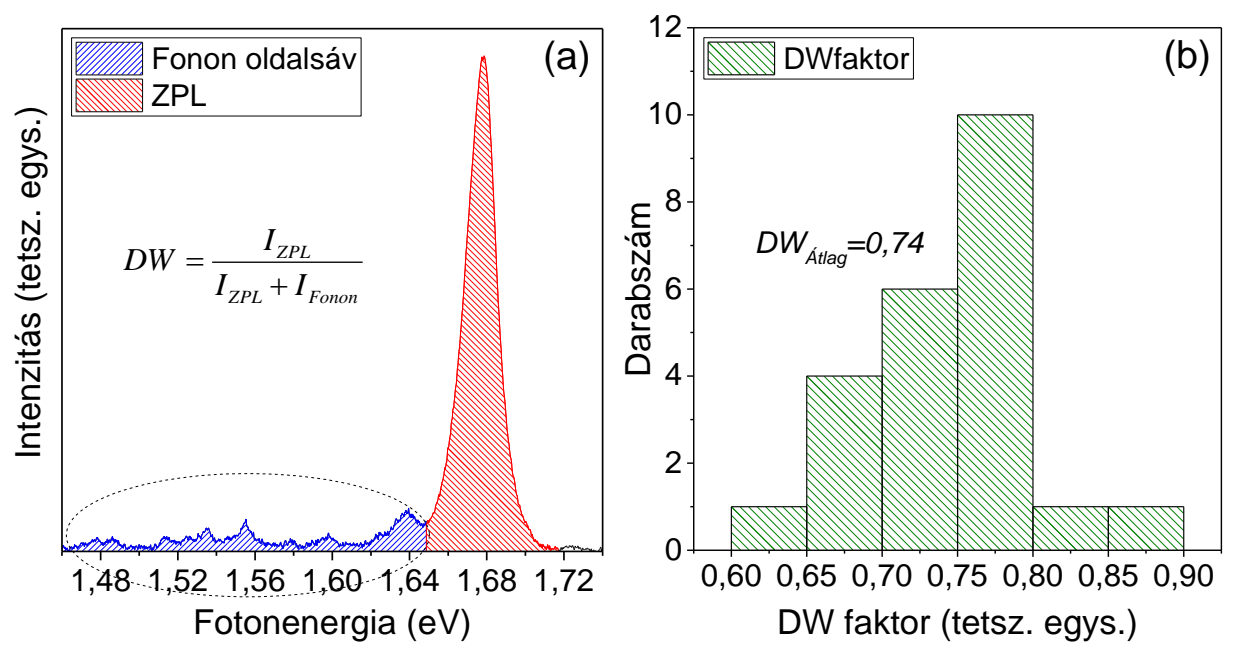

6.25. ábra: A SiV centrum DW faktorának (a) meghatározása a különbözö módon vonalazott ZPL és a fonon oldalsáv intenzitásokból és (b) annak eloszlása a vizsgált rétegekben.

A 6.26. ábra (a) és (b) részén a DW faktor értékének változását ábrázoltam a belső feszültség és az átlagos szemcseméret változásával. A DW faktor értéke nő az eredő nyomófeszültség növekedésével, ami azt jelenti, hogy az emittált fény nagyobb hányada koncentrálódik a zérusfonon vonalba. Ez a fotogenerált töltéshordozó az elektron-fonon csatolás révén lejátszódó relaxáció visszaszorulását jelenti a nagyobb belső feszültségü környezetben. A nagyobb belső feszültség a centrum energianívóinak a szeparációját növeli mind az alap, mind pedig a gerjesztett állapotban, ami hatással van az elektron-fonon csatolással végbemenő relaxációra. Az átlagos szemcseméret hatása a DW faktorra az úgynevezett fononikus tilos sáv kialakulásával magyarázható. A szemcseméret csökkenésével először a gerjesztett állapotban végbemenő relaxációhoz szükséges akusztikus fononok ( $\sim 250 \mathrm{GHz})$ záródnak be, majd $40 \mathrm{~nm}$ alatt már az alapállapotban végbemenő relaxáció fononjai ( 50 $\mathrm{GHz}$ ) sem tudnak terjedni. Ez a hatása a csökkenő szemcseméretnek, mely gyengíti az elektronok csatolását, a DW faktor növekedését eredményezi. A belső feszültségnek és az átlagos szemcseméretnek az elözőekben leírt hatása az elektron-fonon csatolásra azt jelenti, hogy a zérusfonon vonal kiszélesedésének csökkennie kell, tehát a DW faktor és a ZPL vonalkiszélesedésének változása között kapcsolat áll fenn. Ezt a kapcsolatot ábrázoltam a 6.26.(c) ábrán. A várakozásoknak megfelelően 
a lineáris elektron-fonon csatolás erösödése azt eredményezi, hogy csökken a ZPL-ben emittált fény aránya az összemisszióhoz képest. A DW faktor csökkenése az elektron-fonon csatolás erősödését jellemzi, ami jó korrelációban van a zérusfonon vonal félértékszélességének növekedésével.
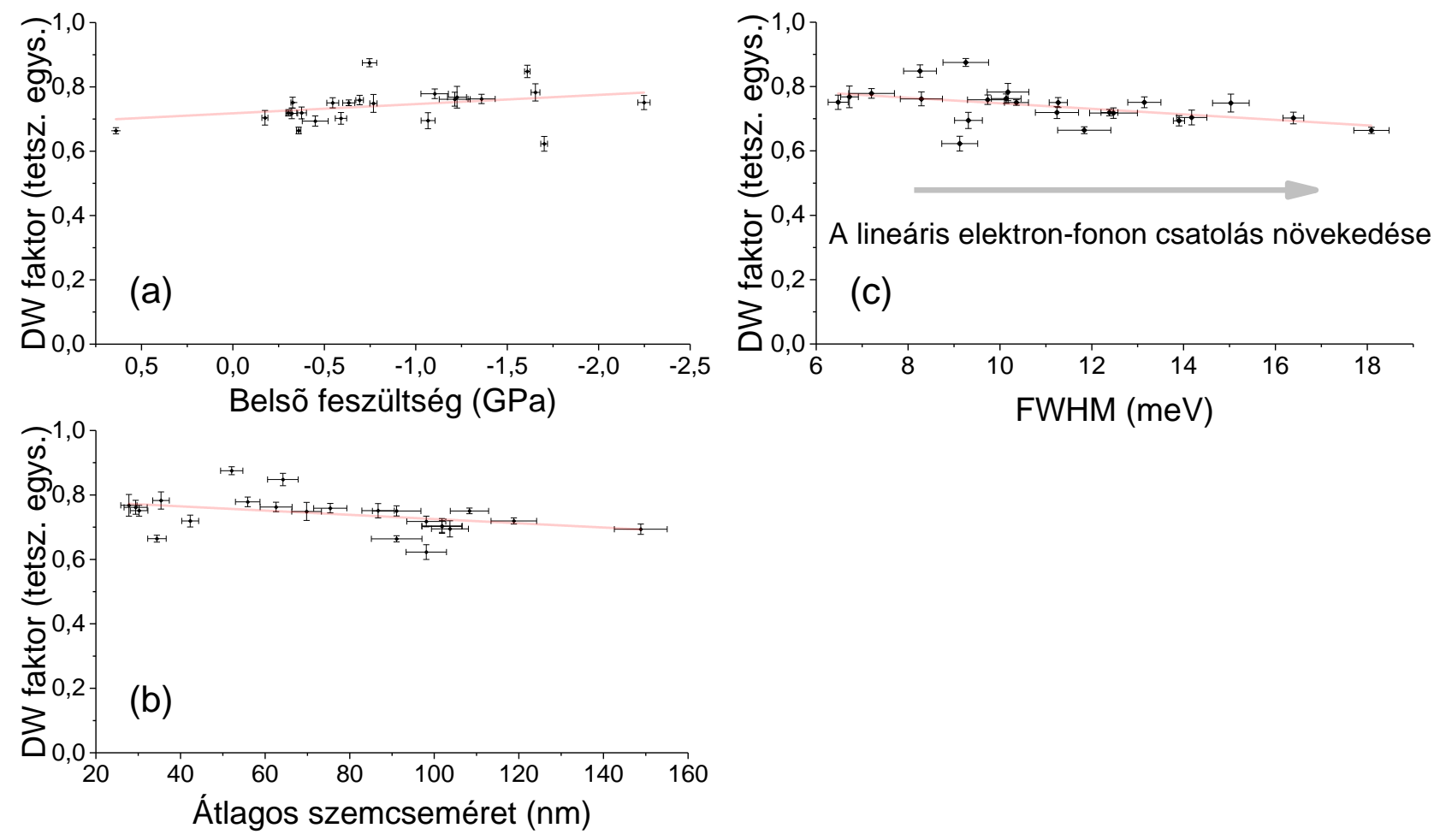

6.26. ábra: A nanogyémánt vékonyrétegekben különbözö paraméterek mellett preparált SiV centrumokra meghatározott DW faktorok változása (a) a belsőfeszültség és (b) az átlagos szemcseméret függvényében. A (c) ábra a DW faktor változását mutatja a ZPL félértékszélességének függvényében.

\subsubsection{A SiV centrum emissziójának fonon oldalsávja}

Az eddigiekben elsősorban azoknak a kísérleti eredményeknek a bemutatására fókuszáltam, melyek a különböző lokális környezettel rendelkező SiV centrumok spektrális paramétereinek a változását igazolták. Illetve, ezen spektrális paraméterek, valamint a DW faktornak a változását vizsgáltam a lokális belső feszültség és az átlagos szemcseméret függvényében. Most azonban nézzük meg van-e változás a fonon oldalsáv szerkezetében, annak jellemző frekvenciáiban. Mivel a fonon oldalsáv szintén a centrum karakterisztikus jellemzője, és annak atomi szerkezetéről is tartalmaz információt, ezért ezen vizsgálatoktól azt várjuk, hogy további információt szolgáltatnak a centrumok eltérő lokális környezete és a spektrális paraméterek változása közötti kapcsolt fizikai hátteréről.

Azt már korábban néhány reprezentatív spektrumon bemutattam, hogy a különbözö paraméterek mellett preparált nanogyémánt vékonyrétegekben a $S i V$ centrumok ZPL-jeinek spektrális 
paraméterein kívül az azokhoz tartozó fonon oldalsávok szerkezete is jelentősen különbözik (lásd a 6.14. ábrán), tehát a fentiekben megfogalmazott feltételezések nem alaptalanok.

Általános esetben egy optikai centrumnál történő elektronátmenet kétféle rezgési módussal hathat kölcsön: a rácsmódusokkal, melyek jelen esetben a gyémánt rács rezgéseinek felelnek meg, valamint a lokális, és kvázi-lokális módusokkal, melyek a centrumnak, mint egységnek a rezgéseit jellemzik. A rácsmódusokkal való csatolást a gyémánt kristályrács fonon állapotsűrüsége határozza meg, melyet elméleti és kísérleti vizsgálatokkal határoztak meg [15, 99, 148]. Ezek alapján a fonon állapotsűrüségi spektrum a nagyenergiájú oldalon egy éles csúcs után levág 168 meV-nál, valamint 70 meV alatt az intenzitása drasztikusan csökken. Ennek következtében a fonon oldalsáv szerkezetek 70 meV alatt és 168 meV fölött kvázi-lokális és lokális módusokhoz rendelhetők. Azok a lokális módusok, melyek energiája a kristályrács rezgési tartományába esik a kvázi-lokális módusokhoz tartoznak [90].

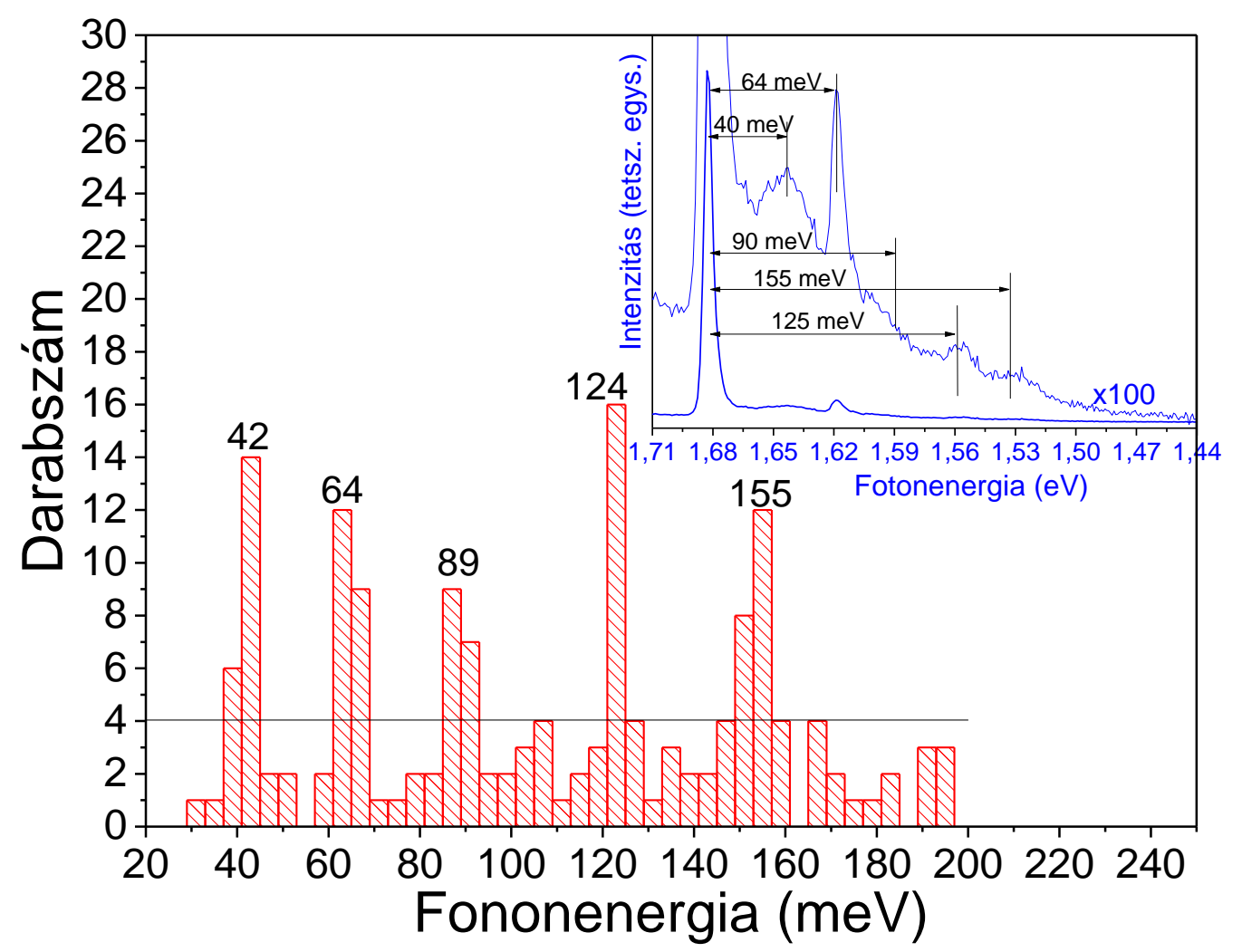

6.27. ábra: A SiV centrum emissziós spektrumának fonon oldalsávjából meghatározott karakterisztikus rezgési energiák statisztikája. A jobb felső sarokban a 10 um szemcseméretü mikrokristályon, 8 K hömérsékleten mért SiV centrum fonon oldalsávjának szerkezete látható.

A 6.27. ábrán a kísérletileg meghatározott karakterisztikus rezgési energiák eloszlása látható, melyet a nanogyémántban, különböző paraméterek mellett kialakított $S i V$ centrumok lumineszcencia spektrumaiból határoztam meg. Összehasonlítás céljából megadtam egy mikrokristályos (10 $\mu \mathrm{m})$ gyémánt minta $S i V$ centrumának fonon szerkezetét $8 \mathrm{~K}$ hőmérsékleten. Az ábrán jól látható, hogy a mikrokristályban található SiV centrumra jellemző rezgési energiák értékeinek közelében a 
nanokristályos gyémántban lévő $S i V$ centrumok többsége is rendelkezik a karakterisztikus rezgési sávval. Ennek ellenére a nanogyémántban némi eltérés megfigyelhető, mely egyik karakterisztikus fononszerkezet esetében sem haladja meg a 2 meV-tot.
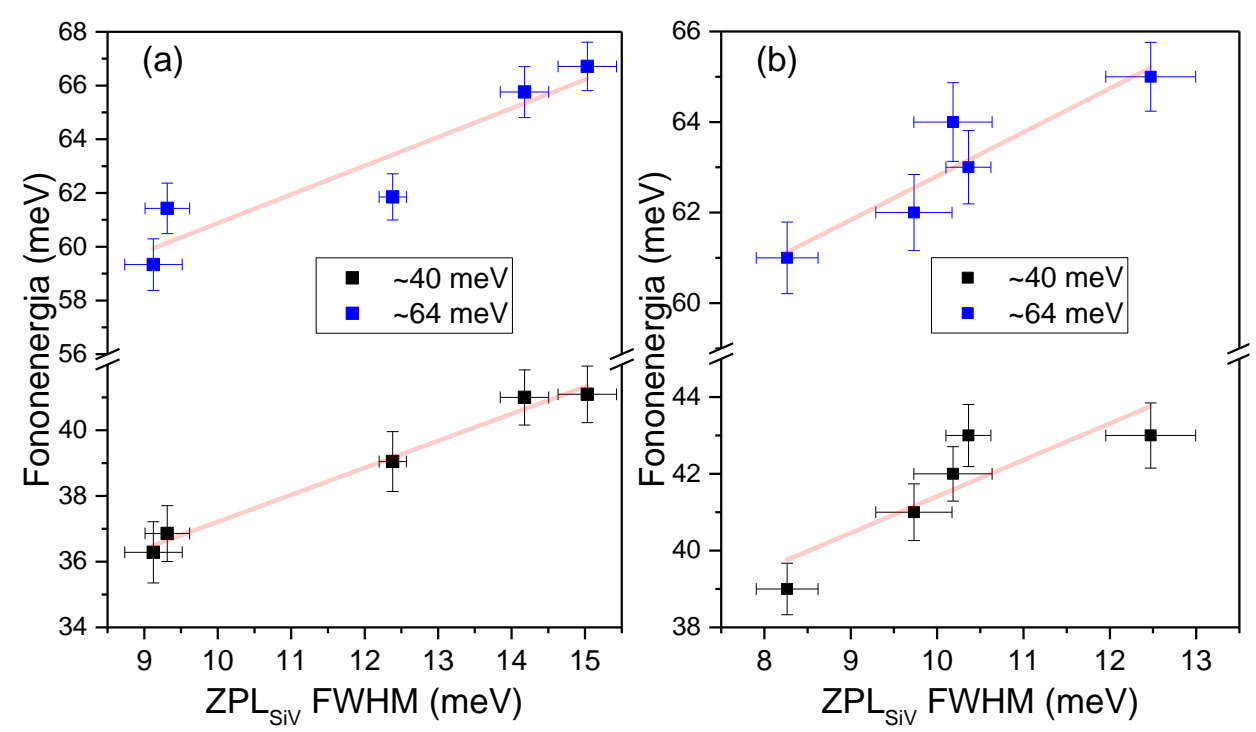

6.28. ábra: A lokális rezgési energiák változása a ZPL félértékszélességének függvényében a (a) 0,2\% és (b) $1 \% \mathrm{CH}_{4}$ koncentráció mellett, különböző hőmérsékleteken leválasztott nanogyémánt sorozatok esetében. A 40 meV közeli lokális energiák a SiV centrum vakancia komponenséhez, míg a

64 meV közeli lokális rezgési energiák a SiV centrum szilícium atomjához rendelhetö rezgések.

Mivel a 40 és 64 meV energiájú rezgések a centrum környezetét jellemzik, ezért várható, hogy a környezetének változása, pl. a belső feszültség növekedése torzítja a kötésszögeket, ami a lokális rezgések frekvenciájának változásában kell, hogy jelentkezzen. A kötésszög torzulása csökkenti a kötés erősségét és így a lokális rezgési energia változását, mégpedig csökkenését eredményezi. A ZPL spektrális paramétereinek vizsgálatánál láttuk, hogy a vonalkiszélesedés jelentősen változik a centrum környezetére jellemző belső feszültséggel (lásd a 6.22.(b) ábrán), így érdemes megnézni, hogy van-e valamilyen kapcsolat a ZPL kiszélesedése és a centrum környezetét jellemző energiák között. A 6.28.as ábrán a $0,2 \%$ és $1 \% \quad \mathrm{CH}_{4}$ koncentrációk mellett, különböző hőmérsékleteken elöállított nanogyémántban lévő SiV centrumok ZPL-jének kiszélesedése függvényében ábrázoltam a centrum környezetére jellemző két lokális rezgési sávot. Azt a kísérleti eredményeim korábbi analízise (6.2.4.2. alfejezet) is mutatta, hogy amint a nyomófeszültség csökken a SiV centrumok környezetében, úgy nő a ZPL félértékszélessége. Ezzel teljesen korrelál a lokális rezgési energiák változása, mivel azok a félértékszélesség növekedésével a tömbi, azaz közel feszültségmentes kristályokban megfigyelt rezgési energiák felé tolódnak. A 6.28. ábrán is jól látható, hogy mindkét mintasorozatnál a lokális rezgések energiája csak a sorozaton belüli legnagyobb ZPL félértékszélességek mellett érik el a nagyméretü kristályokra jellemző rezgési energiákat. 


\section{Összefoglaló:}

A kutatási céljaimmal összhangban SiV lumineszcencia centrumot alakitottam ki nanogyémánt vékonyrétegben különbözö preparációs paraméterek mellett, azért, hogy változtassam a centrumok lokális környezetét. A gyémánt Raman-szórási sávjának csúcspozíciójából meghatároztam a maradék belsö feszültséget ugyanabban a térfogati tartományban, ahol a lumineszcenciát is mértem. Ezt a belsö feszültségértéket a SiV centrumok lokális környezetének, míg a SEM képekböl meghatározott átlagos szemcseméretet a rétegek textúrájának jellemzésére használtam.

A nanogyémánt vékonyrétegeken $10 \times 10 \mu \mathrm{m}^{2}$-es területek lumineszcenciájának pásztázó feltérképezésével meghatároztam a SiV centrumok zérusfonon vonalának spektrális paramétereit, hogy meghatározzam egy adott mintán belül ezeknek a paramétereknek a szórását. A mérések a SiV centrum környezetének homogenitását mutatták az egyes mintákon belül. Ezt követöen a centrum lokális környezetének jellemzésére használt belső feszültség függvényében vizsgálva a SiV ZPL paramétereit megállapitottam, hogy a csúcspozíció nagyobb energiák felé tolódik el, míg a félértékszélesség csökken a belsö feszültség növekedésekor. Ezt a változást a belsö feszültségnek a SiV centrum elektron energianivóira gyakorolt hatásával, és emiatt az elektron-fonon csatolással történö relaxációnak a visszaszorulásával magyaráztam. Továbbá, megállapítottam, hogy a szemcseméret csökkenése a csúcspozíció nagyobb energiák felé történő eltolódását, valamint a félértékszélesség csökkenését eredményezi. Ezen változások a fononikus tiltott sáv megjelenésével magyarázhatóak, amely a szemcseméret változásával a relaxációhoz szükséges akusztikus fononok terjedését gátolja.

A nanogyémánt vékonyrétegekben különbözö paraméterek mellett preparált SiV centrumokra meghatároztam a DW faktort, mely 0,623-0,875 között változik. Igazoltam, hogy a SiV centrum lokális környezetére jellemzö maradék belsö feszültség növekedésével nö a DW faktor és függ a minták textúráját jellemzö átlagos szemcsemérettől is. A SiV centrum DW faktorának kísérletileg tapasztalt változásait a belsö feszültségnek a SiV centrum elektron energianívóira gyakorolt hatásával és a fononikus tilos sáv kialakulásával magyaráztam.

Különbözö mintákban vizsgálva a SiV centrum emissziójának fonon oldalsávját azt tapasztaltam, hogy a lokális rezgések energiája változik az adott mintákban mért ZPL kiszélesedésével. Ebböl arra lehetett következtetni, hogy a lokális belsö feszültségtöl függ a rezgési energia. A nagyobb nyomófeszültség torzítja a kötésszögeket hozzájárulva ezáltal a rezgési energia csökkenéséhez. 


\section{7. Összefoglalás}

A dolgozatban bemutatott eredményeket az alábbi tézispontokban foglalom össze:

1. Kísérletileg igazoltam, hogy mérsékelt ionenergiák $(2-30 \mathrm{keV})$ és iondózisok $\left(1,5-4,5 \times 10^{15}\right.$ ion $/ \mathrm{cm}^{2}$ ) alkalmazása mellett, viszonylag egyszerü és széles körben elérhető plazmaimmerziós ionimplantáció (PIII) és fókuszált ionnyaláb (FIB) implantációs technikákkal, $\mathrm{N}_{2}^{+}$és $\mathrm{He}^{+}$ionokat bejuttatva a nanogyémántba, majd komplex hőkezelés utólagos alkalmazásával, a mélykék hullámhossztartományban, szobahőmérsékleten is intenzíven emittáló szennyezési centrumokat lehet kialakítani $12 \mathrm{~nm}$ körüli átlagos szemcsemérettel rendelkező nanogyémánt kristálykákban. SRIM szimulációs programcsomag segítségével meghatároztam az $\mathrm{N}_{2}^{+}$és $\mathrm{He}^{+}$ionok implantációs mélységét és a létrehozott rácshibák mélységeloszlását. [T1]

2. Az implantált nanogyémánt lumineszcencia spektrumainak részletes vizsgálatával megmutattam, hogy a mélykék hullámhossztartományban detektált intenzív és keskeny emissziós sáv a szénvakancia körül elhelyezkedö, 3 db nitrogént tartalmazó komplex hibahelyszerkezethez, az ún. N3 centrumhoz rendelhető. Ezt a lumineszcencia spektrum alakja és az illesztéssel meghatározott zérusfonon vonal csúcspozíciója $(\sim 2,985 \mathrm{eV})$ is megerösíti. A ZPL nagy $(68-75 \mathrm{meV})$ spektrális vonalszélessége az inhomogén kiszélesedéssel függ össze, amit az N3 centrumok lokális környezetének különböző mértékü relaxációja magyaráz. [T1, T2]

3. A $8 \mathrm{~K}$ hömérsékleten mért lumineszcencia spektrumok fonon oldalsávjának részletes vizsgálata során megmutattam, hogy a kialakított komplex szennyezési centrum vakanciát tartalmaz és a tömbi gyémántban vizsgált $N 3$ centrumra jellemző fononszerkezetek rezgési energiáival jó egyezést mutat. A szintén $8 \mathrm{~K}$ hőmérsékleten mért gerjesztési spektrumok maximuma az N3 centrumra jellemzően 3,37 eV fotonenergiánál található és a nagyenergiájú oldalon 3,66 eV-nál lokális maximummal rendelkezik, mely az említett hibahelyszerkezethez tartozó, ún. N4 optikai átmenet. [T2]

4. $10 \times 10 \mu \mathrm{m}^{2}$ nagyságú területek lumineszcenciájának pásztázó feltérképezésével megmutattam, hogy egy adott paraméterkombináció mellett leválasztott nanogyémánt vékonyrétegben a szilícium-vakancia centrumok környezete kis eltérést mutat, mivel a zérusfonon vonal spektrális paramétereinek a szórása egy keskeny, 0,8 meV-os sávon belül marad. A gerjesztő fotonenergia változtatásával igazoltam, hogy a különböző feltételek mellett preparált szilícium-vakancia centrumok zérusfonon vonalának aszimmetrikus alakját a GRl centrum emissziója okozza. Pásztázó lumineszcenciás mérésekkel megmutattam, hogy a nagy lokális GRl koncentrációval rendelkező területeken a $S i V$ centrum emissziójától jól elkülöníthető a GRl centrum emissziója. [P1] 
5. A preparálási feltételek változtatásával módosítottam a $S i V$ centrumok lokális környezetét a nanogyémánt vékonyrétegekben. A SiV centrumok lokális környezetének jellemzésére a nanogyémánt rétegben kialakult eredő belső feszültséget használtam, amelyet a nanogyémánt Raman-szórási csúcsából határoztam meg. Megmutattam, hogy a SiV centrum zérusfonon vonalának spektrális paraméterei változnak a belső feszültséggel. A ZPL csúcspozíciója 2,6 meV kékeltolódást szenved, míg a félértékszélessége 18,1 meV-ról 6,4 meV-ra csökken, amint a nanogyémánt rétegben az eredő belső feszültség 0,64 GPa húzófeszültségről 2,25 GPa nyomófeszültségre változik. A kísérleti eredmények lehetséges magyarázata, hogy a nagyobb lokális nyomófeszültség megnöveli a $\mathrm{SiV}$ centrum elektron energianívóinak a felhasadását az alap és gerjesztett állapotban egyaránt, visszaszorítva a kis energiájú akusztikus fononok közremüködésével végbemenő pályarelaxációt. [T3, T4]

6. A különböző feltételek mellett kialakított szilícium-vakancia centrumok zérusfonon vonalának spektrális paraméterei változnak a nanogyémánt réteg textúrájának jellemzésére használt átlagos szemcsemérettel. A ZPL csúcshelyzete a nagyobb energiák felé tolódik, míg a vonalkiszélesedése kisebb lesz, amint az átlagos szemcseméret 150 nm-röl 30 nm-re csökken. Ez a változási tendencia a nanogyémánt szemcsék méretével összefüggő fonon tilos sáv kialakulásával hozható kapcsolatba, ami a kis energiájú akusztikus fononok terjedését korlátozza és így a fotogerjesztést követő relaxációs folyamatokat is. A $120 \mathrm{~nm}$-nél kisebb szemcsékben teljes fonon tilos sáv alakul ki a $v<50 \mathrm{GHz}$ frekvenciájú akusztikus fononokra a bezáródás miatt. [T4] 


\section{Summary}

The new scientific results achieved in my research work are summarized in the following Thesis:

1. I showed experimentally that color centers emitting intensively even at room temperature in the deep blue wavelength region can be created in nanodiamond crystallites of $\sim 12 \mathrm{~nm}$ average grain size by the implantation of $\mathrm{N}_{2}^{+}$and $\mathrm{He}^{+}$ions at moderate ion energies (2-30 keV) and ion doses (1.5$4.5 \times 10^{15}$ ions $/ \mathrm{cm}^{2}$ ) using relatively simple and widely available plasma immersion ion implantation (PIII) or focused ion beam (FIB) techniques and subsequent complex heat treatments. The implantation depth of $\mathrm{N}_{2}^{+}$and $\mathrm{He}^{+}$ions and the distribution of the created lattice defects were determined using the SRIM simulation program. [T1]

2. By the detailed investigation of the photoluminescence spectra of implanted nanodiamonds I showed that the intensive and narrow emission band detected in the deep blue wavelength region is related to a complex nitrogen-vacancy defect structure, the so called $N 3$ center. This was confirmed by the shape of the emission band and the position of the zero phonon line $(\sim 2.985 \mathrm{eV})$ determined by fitting. The significant ZPL broadening (of $68-75 \mathrm{meV}$ ) observed in our samples is related to the inhomogeneous line broadening mechanism, caused by the differently relaxed local environment of the $N 3$ centers. [T1, T2]

3. By the investigation of the phonon sideband structures in the photoluminescence spectra recorded at $8 \mathrm{~K}$ I showed that the created complex defect center contains a vacancy fragment and the position of fine structures are in good agreement with the vibrational energies of phonon structures characteristic for the $N 3$ center created in bulk diamond. The maximum of luminescence excitation spectrum recorded at $8 \mathrm{~K}$ is located at $3.37 \mathrm{eV}$, which is typical for $N 3$ center. The local maximum at $3.66 \mathrm{eV}$ was assigned to the so called N4 optical transition related to the same N3 defect structure. [T2]

4. By mapping the spectral parameters of the SiV ZPL within a $10 \times 10 \mu \mathrm{m}^{2}$ area on nanodiamond thin films I showed that the SiV centers have only slightly different environment. The deviation of the spectral parameters does not exceed $0.8 \mathrm{meV}$ for a sample deposited at given conditions. Using multiwavelength laser excitation I showed that the asymmetric line shape of the $\mathrm{SiV}$ centers formed at different conditions is caused by the emission of the GRl center. By scanning photoluminescence measurements I showed that the emission of the GRI center is well distinguishable from the emission of the SiV center in areas with high local concentration of the GRI centers. [P1] 
5. By using different preparation conditions $S i V$ centers of different local surroundings were formed in nanodiamond thin films. The residual internal stress in the local vicinity of $\mathrm{SiV}$ centers, determined from the diamond Raman peak was used to characterize the local surrounding of the $\mathrm{SiV}$ centers. I showed that the spectral parameters of the zero phonon line of the $\mathrm{SiV}$ center depend on the internal stress. The ZPL peak position was found to be blue-shifted by $2.6 \mathrm{meV}$ and narrowed from $18.1 \mathrm{meV}$ to $6.4 \mathrm{meV}$ when the tensile internal stress of $0.64 \mathrm{GPa}$ changes to compressive stress of 2.25 GPa. The dependence of the ZPL spectral parameters on the local internal stress can be explained by the higher splitting of both the ground and excited states of the electronic levels of the SiV center due to the increased local internal stress, which suppresses the rate of the orbital relaxation via low energy acoustic phonons. [T3, T4]

6. I showed that the ZPL spectral parameters of SiV centers created under different conditions depend on the average grain size used to characterize the texture of the nanodiamond films. The ZPL peak position shifts to higher values and the peak narrows when the average grain size decreases from $150 \mathrm{~nm}$ to $30 \mathrm{~nm}$. This tendency can be related to phononic band gap being dependent on the size of the nanodiamond grains, which restricts the propagation of acoustic phonons and so the relaxation processes following the photoexcitation. The confinement causes the formation of a total phononic band gap in grains having size below $120 \mathrm{~nm}$ for the acoustic phonons with $<50 \mathrm{GHz}$ frequency. [T4] 


\section{Publikációk}

\section{A disszertáció alapjául szolgáló közlemények:}

[T1] Himics L., Tóth S., Veres M., Tóth, A. and Koós M. (2015). Effective implantation of light emitting centers by plasma immersion ion implantation and focused ion beam methods into nanosized diamond, Applied Surface Science 328, 577.

[T2] Himics L., Tóth S., Veres M., Balogh Z. and Koós M. (2014). Creation of deep blue light emitting nitrogen-vacancy center in nanosized diamond, Applied Physics Letters, 104(9), 093101-01.

[T3] Himics L., Tóth S., Veres M., Csíkvári P. and Koós M. (2015). Influence of microwave plasma parameters on light emission from $\mathrm{SiV}$ color centers in nanocrystalline diamond films, Open Chemistry, 13(1), 263.

[T4] Himics L., Tóth S., Veres M. and Koós M. (2016). Spectral properties of the zero-phonon line from ensemble of silicon-vacancy center in nanodiamond, Optical and Quantum Electronics 48(8), 394.

[P1] Himics L., Tóth S., Veres M., Rigó I. and Koós M. (2016). Investigation of the 1.68eV NearInfrared Emission Lineshape in Nanodiamond Films by Selective Laser Excitation, International Conference on Advanced Laser Technologies (ALT) 2016, 2016. szeptember 12-16., Galway, Írország (poszter).

\section{A disszertáció témájához kapcsolódó közlemények:}

1. Tóth S., Himics L. and Koós, M. (2016). Creation of near-infrared emitting optical center related to nickel-silicon impurity complex in nanodiamond grains, Journal of Luminescence, 176, 367-371.

2. Tóth S., Himics L. and Koós M. (2015). Nickel-Silicon Related Color Center Formed in Nanodiamond Grains under CVD Growth, Journal of Nanoscience 2016, 282967.

3. Tóth S., Himics L., Veres M., Balogh Z., Ralchenko V. G. and Koós M. (2015). Zero-phonon line characteristics of $\mathrm{SiV}$ center emission in microcrystalline diamond probed with intensive optical excitation, Journal of Luminescence, 158, 260-264.

4. $\quad$ Himics L., Tóth S., Veres M., Czitrovszky A., Nagy A., Oszetzky D., Kerekes A., Kugler Sz., Rigó I., Tóth A. and Koós M. (2015). Creation of blue light emitting color centers in nanosized diamond for different applications, In Nanoscience Advances in CBRN Agents Detection, Information and Energy Security (pp. 93-101). Springer Netherlands. 
5. Veres M., Koós M., Tóth S., and Himics L. (2010). Sp2 carbon defects in nanocrystalline diamond detected by Raman spectroscopy, In IOP Conference Series: Materials Science and Engineering (Vol. 15, No. 1, p. 012023).

6. Petkov C., Glebe U., Petkov E., Pasquarelli A., Pietzka, C., Veres M., Himics L., Merz R., Kulisch W., Siemeling U., Reithmaier, J.P. and Popov C. (2013). Grafting of manganese phthalocyanine on nanocrystalline diamond films, Physica Status Solidi (a), 210(10), 20482054.

\section{Egyéb közlemények:}

7. Mitsa V., Holomb R., Marton A., Veres M., Tóth S., Himics L., ... and Popescu M. (2016). Investigation of atmospheric corrosion by photon energy dependent luminescence and Raman spectroscopy in aged and freshly fractured g-, c-As 2 S 3 with photosensitive realgar inclusions. Journal of Non-Crystalline Solids, 453, 23-27.

8. Ignatovych M., Borysenko M., Davydenko L., Borysenko L., Veres M., Himics L. and Koós M. (2016). Cerium and europium nanospecies in quartz glass: synthesis and spectral study. Materialwissenschaft und Werkstofftechnik, 47(2-3), 193-197.

9. Rigó I., Veres M., Himics L., Tóth S., Czitrovszky A., Nagy A. and Fürjes, P. (2016). Comparative analysis of SERS substrates of different morphology. PROCEDIA ENGINEERING.

10. Bonyar A., Csarnovics I., Veres M., Himics L., Csík A., Kaman J., ... and Kökényesi S. (2016). Investigation of the performance of thermally generated $\mathrm{Au} / \mathrm{Ag}$ nanoislands for SERS and LSPR applications. PROCEDIA ENGINEERING.

11. Kerekes A., Veres M., Himics L., Tóth S., Czitrovszky A., Nagy A. and Koós M. (2015). Determination of the distribution of inhaled drugs in human airways by Raman spectroscopy. In Nanoscience Advances in CBRN Agents Detection, Information and Energy Security (pp. 437-442). Springer Netherlands.

12. Bányász I., Rajta I., Nagy G. U. L., Zolnai Z., Havranek V., Himics L., Pelli S., ... and Righini G. C. (2014, March). Ion beam irradiated optical channel waveguides. In SPIE OPTO (pp. 898814-898814). International Society for Optics and Photonics.

13. Veres M., Tóth A., Mohai M., Bertóti I., Szépvölgyi J., Tóth S., Himics L., ... and Koós M. (2012). Two-wavelength Raman study of poly (ethylene terephthalate) surfaces modified by helium plasma-based ion implantation. Applied Surface Science, 263, 423-429. 


\section{Irodalomjegyzék:}

[1] Zaitsev, A. M., Optical properties of diamond: a data handbook. Springer Science \& Business Media, 2013.

[2] Balmer, R. S. et al., Journal of Physics: Condensed Matter 21 (2009), 364221.

[3] Schwander, M., \& Partes, K., Diamond and Related Materials 20 (2011), 1287-1301.

[4] Dolmatov, V. Y., Russian Chemical Reviews 70 (2001), 607-626.

[5] Ferro, S., Journal of Materials Chemistry 12 (2002), 2843-2855.

[6] Neu, E. K., Silicon vacancy color centers in chemical vapor deposition diamond: New insights into promising solid state single photon sources, (2012).

[7] Breeding, C. M., \& Shigley, J. E., Gems \& Gemology 45 (2009), 96-111.

[8] Aharonovich, I. et al., Reports on Progress in Physics 74 (2011), 076501.

[9] Aharonovich, I., \& Neu, E. Advanced Optical Materials 2 (2014), 911-928.

[10] Achatz, P., Applied Physics Letters, 88 (2006), 101908-101908.

[11] Nesládek, M., Physical Review B 54 (1996), 5552.

[12] Walker, J., Reports on Progress in Physics 42 (1979), 1605.

[13] Bharuth-Ram, K, Physical Review B 64 (2001), 195207.

[14] Bharuth-Ram, K., Beam Interactions with Materials and Atoms 190 (2002), 835-839.

[15] Zaitsev, A. M. Physical Review B 61 (2000), 12909.

[16] Santori, C. et al., Nanotechnology 21 (2010), 274008.

[17] Babinec, T. M. et al., Nature Nanotechnology 5 (2010), 195-199.

[18] Faraon, A. et al., Nature Photonics 5 (2011), 301-305.

[19] Riedrich-Möller, J. et al., Nature Nanotechnology 7 (2012), 69-74.

[20] Friel, I. et al., Diamond and Related Materials 18 (2009), 808-815.

[21] Mildren, R. P. et al., Optics Express 16 (2008), 18950-18955.

[22] Dobrinets, I. A., Vins, V. G., \& Zaitsev, A. M., HPHT-treated diamonds (p. 257). Springer Verlag, 2013.

[23] Smith, W. V., Sorokin, P. P., Gelles, I. L., \& Lasher, G. J., Physical Review 115 (1959), 1546.

[24] Tucker, O. D., Newton, M. E., \& Baker, J. M., Physical Review B 50 (1994), 15586.

[25] Boyd, S. R., Kiflawi, I., \& Woods, G. S., Philosophical Magazine B 69 (1994), 1149-1153.

[26] Rondin, L. et al., Physical Review B 82 (2010), 115449.

[27] Gaebel, T et al., Nature Physics 2 (2006), 408-413.

[28] Faklaris, O. et al., Small 4 (2008), 2236-2239.

[29] Maze, J. R. et al., Nature 455 (2008), 644-647.

[30] Nayar, P. G., Proceedings Mathematical Sciences 14 (1941), 1-17.

[31] Loubser, J., \& van Wyk, J., Reports on Progress in Physics 41 (1978), 1201.

[32] Runciman, W. A., Proceedings of the Physical Society 86 (1965), 629.

[33] https://en.wikipedia.org/wiki/Crystallographic_defects_in_diamond

[34] Shcherbakova, M.Y. et al., Journal of Structural Chemistry 19 (1978), 261-269.

[35] Collins, A. T., Kamo, M., \& Sato, Y., Journal of Materials Research 5 (1990), 2507-2514.

[36] Kiflawi, I., \& Bruley, J., Diamond and Related Materials 9 (2000), 87-93. 
[37] Woods, G. S., Philosophical Magazine B 50 (1984), 673-688.

[38] Varichenko, V.S., Zaitsev, A.M., Stelmakh, V.F., Physica Status Solidi A 95 (1986), K25-K28.

[39] Teicher, M., \& Beserman, R., Journal of Applied Physics 53 (1982), 1467-1469.

[40] Gippius, A. A. et al., Physica B+ C 116 (1983), 187-194.

[41] Kompan, M. E. et al., Physics of the Solid State 39 (1997), 1928-1929.

[42] Mikov, S. N., Igo, A. V., Gorelik, V. S., Physics of the Solid State 41 (1999), 1012-1014.

[43] Gorelik, V. S., Rakhmatullaev, I. A., Inorganic Materials 40 (2004), 686-689.

[44] Yu, S. J. et al., Journal of the American Chemical Society 127 (2005), 17604-17605.

[45] Naydenov, B. et al., Applied Physics Letters 96 (2010), 163108.

[46] Aharonovich, I., Physical Review B 81 (2010), 121201.

[47] Willardson, R. K., Weber, E. R., \& Stavola, M., Identification of Defects in Semiconductors (Vol. 51). Academic Press, 1998.

[48] Walker, J., Vermeulen, L. A., \& Clark, C. D., Proceedings of the Royal Society of London A: Mathematical, Physical and Engineering Sciences 341 (1974), 253-266.

[49] Coomer, B. J., A first principles study of defects in semiconductors, University of Exeter, 1997.

[50] Vij, D. R. (Ed.)., Luminescence of solids. Springer Science \& Business Media, 2012.

[51] Peter, Y. U., \& Cardona, M., Fundamentals of semiconductors: physics and materials properties, Springer Science \& Business Media, 2010.

[52] Thomaz, M. F., Davies, G., Proceedings of the Royal Society of London A: Mathematical, Physical and Engineering Sciences 362 (1978), 405-419.

[53] Iakoubovskii, K., Adriaenssens, G. J., Physical Review B 61 (2000), 10174.

[54] Rand, S. C., Optics Letters 13 (1988), 140-142.

[55] Jones, R., Goss, J. P., Briddon, P. R., Öberg, S., Physical Review B 56 (1997), R1654.

[56] Crowther, P. A., Dean, P. J., Journal of Physics and Chemistry of Solids 28 (1967), 1115-1136.

[57] Gaillou, E. et al., Diamond and Related Materials 19 (2010), 1207-1220.

[58] Gordon Davies, Properties and growth of diamond. INSPEC, the Institution of Electrical Engineers, 1994.

[59] Hsiao-Chi, L. et al., Optics and Photonics Journal 3 (2013), 25-28.

[60] Audoit, G. et al., Journal of Materials Chemistry 15 (2005), 4809-4815.

[61] Xia, R. et al., IEEE Photonics Technology Letters 14 (2002), 893-895.

[62] Davies, G., Journal of Physics C: Solid State Physics 7 (1974), 3797.

[63] Maradudin, A. A., Solid State Physics 18 (1966), 273-420.

[64] Stoneham, A. M., Theory of defects in solids: electronic structure of defects in insulators and semiconductors. Oxford University Press, (2001).

[65] Vavilov, V. S., Gippius, A., Sov. Phys. Semicond. 14 (1980), 1078-1079.

[66] Ruan, J., Choyke, W. J., \& Partlow, W. D., Journal of Applied Physics 69 (1980), 6632-6636.

[67] Bergman, L. et al., Journal of Applied Physics 73 (1993), 3951-3957.

[68] Gorokhovsky, A.A. et al., Applied Physics Letters 66 (1995), 43-45.

[69] Hepp, C. et al., Physical Review Letters 112 (2014), 036405.

[70] Musale, D.V., Sainkar, S.R., Kshirsagar, S.T., Diamond and Related Materials 11 (2002), 75.

[71] Sittas, G., Kanda, H., Kiflawi, I., Spear, P.M., Diamond and Related Materials 5 (1996), 866. 
[72] Breeding, C. M., \& Wang, W., Diamond and Related Materials 17 (2008), 1335-1344.

[73] Zaitsev, A.M., Vavilov, V.S., Gippius, A.A, Sov. Phys. Lebedev Inst. Rep. 10 (1981), 15-17.

[74] Clark, C. D., Dickerson, C. B., Surface and Coatings Technology 47 (1991), 336-343.

[75] Collins, A. T. et al., Diamond and Related Materials 3 (1994), 932-935.

[76] Iakoubovskii, K. et al., Journal of Physics: Condensed Matter 12 (200), 189.

[77] Feng, T., Schwartz, B. D., Journal of Applied Physics 73 (1993), 1415-1425.

[78] Jahnke, K. D., Low temperature spectroscopy of single colour centres in diamond-the siliconvacancy centre in diamond, Universität Ulm, 2015.

[79] Sternschulte, H. et al., Physical Review B 50 (1994), 14554.

[80] Clark, C. D., Kanda, H., Kiflawi, I., \& Sittas, G., Physical Review B 51 (1995), 16681.

[81] Goss, J. P. et al., Physical Review B 72 (2005), 035214.

[82] Brown, S. W., Rand, S. C., Journal of Applied Physics 78 (1995), 4069-4075.

[83] Sternschulte, H. et al., Diamond and Related Materials 4 (1995), 1189-1192.

[84] Wang, C. et al., Journal of Physics B: Atomic, Molecular and Optical Physics 39 (2005), 37.

[85] Basov, A. A. et al., Physica Status Solidi (a) 206 (2009).

[86] Barjon, J. et al., Physica Status Solidi (a) 202 (2005), 2177-2181.

[87] Neu, E. et al., Applied Physics Letters 98 (2011), 243107.

[88] Goss, J. P. et al., Physical Review Letters 77 (1996), 3041.

[89] Iakoubovskii, K., Adriaenssens, G. J., Diamond and Related Materials 9 (200), 1349-1356.

[90] Neu, E. et al., Physical Review B 84 (2011), 205211.

[91] Bergman, L., Nemanich, R. J., Journal of Applied Physics 78 (1995), 6709-6719.

[92] Rossi, M. C. et al., Diamond and Related Materials 6 (1997), 1564-1567.

[93] Siyushev, P. et al., Physical Review Letters 110 (2013), 167402.

[94] Müller, T. et al., New Journal of Physics 13 (2011), 075001.

[95] Siyushev, P. et al., New Journal of Physics 11 (2009), 113029.

[96] Vlasov, I. I. et al., Advanced Materials 21 (2009), 808-812.

[97] Neu, E., New Journal of Physics 13 (2011), 025012.

[98] Davies, G., Reports on Progress in Physics 44 (1981), 787.

[99] Lin-Chung, P. J., Physical Review B 50 (1994), 16905.

[100] Wehner, R. et al., Solid State Communications 5 (1967), 307-309.

[101] Solin, S. A., Ramdas, A. K., Physical Review B 1 (1970), 1687.

[102] Brout, R., Visscher, W., Physical Review Letters 9 (1962), 54.

[103] Von Kaenel, Y. et al., Physica Atatus Solidi (a) 154 (1996), 219-238.

[104] Mochalin, V. N. et al., Nature Nanotechnology 7 (2012), 11-23.

[105] Lieberman, M. A., Journal of Applied Physics 66 (1989), 2926-2929.

[106] Melngailis, J., Journal of Vacuum Science \& Technology B 5 (1987), 469-495.

[107] Giber János, Vargáné Josepovits Katalin, Gyulai József, Biró László Péter: Diffúzió és implantáció szilárdtestekben (Egyetemi tankönyv, Műegytemi Kiadó, 1997)

[108] Rabeau, J. R. et al., Applied Physics Letters 88 (2005), 023113.

[109] Mona, J. et al., Journal of Applied Physics 113 (2013), 114907. 
[110] Ziegler, J. F., Ziegler, M. D., Biersack, J. P. Nuclear Instruments and Methods in Physics Research Section B: Beam Interactions with Materials and Atoms 268 (2010), 1818-1823.

[111] Koike, J., Parkin, D. M., Mitchell, T. E., Applied Physics Letters 60 (1992), 1450-1452.

[112] Vereshchagin, A. L., Sakovich, G. V., Mendeleev Communications 11 (2001), 39-41.

[113] Ullmann, J., Delan, A., Schmidt, G., Diamond and Related Materials 2 (1993), 266-271.

[114] Butler, J. E., Sumant, A. V., Chemical Vapor Deposition 14 (2008), 145-160.

[115] Butler, J. E. et al., Philosophical Transactions of the Royal Society of London A: Mathematical, Physical and Engineering Sciences 342 (1993), 209-224.

[116] D’Evelyn, M. P. et al., Journal of Applied Physics 71 (1992), 1528-1530.

[117] Johnson, C.E., Weimer, W.A., Cerio, F.M., Journal of Materials Research 7 (1992), 1427-1431.

[118] Martin, L. R., Journal of Materials Science Letters 12 (1993), 246-248.

[119] Larson, J. M., Girshick, S. L., Diamond and Related Materials 12 (2003), 1584-1593.

[120] Ferrari, A. C., Robertson, J., Physical Review B 63 (2001), 121405.

[121] Osswald, S. et al., Physical Review B 80 (2009), 075419.

[122] Yoshikawa, M. et al., Applied Physics Letters 67 (19955), 694-696.

[123] Prawer, S. et al., Chemical Physics Letters 332 (2000), 93-97.

[124] Uchinokura, K., Sekine, T., Matsuura, E., Solid State Communications 11 (1972), 47-49.

[125] Sternschulte, H. et al., Diamond and Related Materials 15 (2006), 542-547.

[126] https://imagej.nih.gov/ij/

[127] Chung, P. H., Perevedentseva, E., Cheng, C. L., Surface Science 601 (2007), 3866-3870.

[128] Obraztsova, E. D. et al., Nanostructured Materials 6 (1995), 827-830.

[129] Wang, Z., Xu, C., Liu, C., Journal of Materials Chemistry C 1 (2013), 6630-6636.

[130] Hu, S. et al., Materials Science and Engineering: B 157 (2009), 11-14.

[131] Pereira, E., Pereira, L., Raue, R., Diamond and Related Materials 1 (1992), 901-905.

[132] Turner, S. et al., Advanced Functional Materials 19 (2009), 2116-2124.

[133] Pezzagna, S. et al., New Journal of Physics 13 (2011), 035024

[134] Deák, P. et al., Physical Review B 89 (2014), 075203.

[135] Petráková, V., Advanced Functional Materials 22 (2012), 812-819.

[136] Reyntjens, S., Puers, R., Journal of Micromechanics and Microengineering 11 (2001), 287.

[137] Lawson, S. C. et al. Journal of Physics: Condensed Matter 4 (1992), 3439.

[138] Sastry, M. D., International Journal of Luminescence and Applications 3 (2013), 23-26.

[139] Harley, R. T. et al., Journal of Physics C: Solid State Physics 17 (1984), L233.

[140] Sobolev, E. V., Eliseev, A. P., Journal of Structural Chemistry 17 (1976), 802-804.

[141] Dexter, D. L., The Journal of Chemical Physics 21 (1953), 836-850.

[142] Arend, C. et al., Physical Review B 94 (2016), 045203.

[143] Stoneham, A. M., Reviews of Modern Physics 41 (1969), 82.

[144] Chen, K. H. et al., Diamond and Related Materials 4 (1995), 460-463.

[145] Sipahigil, A. et al., Physical Review Letters 113 (2014), 113602.

[146] Jahnke, K. D. et al., New Journal of Physics 17 (2015), 043011.

[147] Albrecht, A. et al., New Journal of Physics 15 (2013), 083014.

[148] Windl, W. et al., Physical Review B 48 (1993), 3164. 


\section{Köszönetnyilvánítás}

Ezúton szeretnék köszönetet mondani mindazoknak, akik valamilyen módon hozzájárultak munkám sikeréhez és a dolgozatom elkészítéséhez. Elsősorban köszönettel tartozom témavezetőmnek, Koós Margitnak a folyamatos támogatásáért, hasznos tanácsaiért és útmutatásaiért, valamint a rengeteg biztatásért, amelyekkel jelentős mértékben hozzájárult a munkám sikeréhez.

Köszönet illeti a kutatócsoportunk további tagjait, Tóth Sárát, Veres Miklóst és Rigó Istvánt a kutatásaimhoz nyújtott segítségükért. Továbbá köszönöm belső konzulensemnek, Nánai Lászlónak, a támogatását.

Köszönetem szeretném kifejezni Tóth Andrásnak a minták különböző módszerekkel végzett ionimplantálásáért, Csíkvári Péternek a nanogyémánt vékonyrétegek elóállításában nyújtott segítségéért, valamint Kovács Lászlónak az alacsony hőmérsékleten végzett mérésekhez szükséges kriosztát rendelkezésemre bocsájtásáért.

Köszönetet szeretnék mondani az MTA WIGNER FK SZFI igazgatóinak, Buka Ágnesnek és Czitrovszky Aladárnak, továbbá a WIGNER FK teljes vezetőségének a kutatómunkámhoz szükséges megfelelö légkör biztosításáért.

A fenti eredmények a következö szervezetek támogatásával születtek:

- Magyar Tudományos Akadémia,

- Országos Tudományos Kutatási Alapprogramok. 


\section{Függelékek}

12.1. függelék Az N3 centrum kialakitásához használt robbantással elöállitott (NEOMOND Ltd.), por állagú gyémánt nanokristályok paraméterei:

\begin{tabular}{lc}
\hline \multicolumn{1}{c}{ Tulajdonságok } & \multicolumn{1}{c}{ Érték } \\
\hline Szemcseméret & $3 \sim 20 \mathrm{~nm}$ \\
Fajlagos felület & $270-335 \mathrm{~m}^{2} / \mathrm{g}$ \\
Alak & közelítőleg gömb \\
Sủrüség & $3,05 \sim 3,3 \mathrm{~g} / \mathrm{cm}^{3}$ \\
Törésmutató & 2,417 \\
\hline
\end{tabular}

12.2 függelék Az egyes nanogyémánt vékonyrétegek leválasztási paraméterei, rétegvastagsága és átlagos szemcsemérete:

\begin{tabular}{cccccc}
\hline $\begin{array}{c}\text { THORDOzó } \\
\left({ }^{\circ} \mathrm{C}\right)\end{array}$ & $\begin{array}{c}\text { Metánarány } \\
(\%)\end{array}$ & Minta & $\begin{array}{c}\text { Rétegvastags. } \\
(\mathrm{nm})\end{array}$ & $\begin{array}{c}\text { Átl. szemcseméret } \\
(\mathrm{nm})\end{array}$ & $\begin{array}{c}\text { Eredö belső feszültség* } \\
(\mathrm{GPa})\end{array}$ \\
\hline 650 & 0,2 & 53 & 156 & $69,8 \pm 3,6$ & $-0,77 \pm 0,02$ \\
650 & 0,5 & 52 & 250 & $52,1 \pm 2,7$ & $-0,75 \pm 0,03$ \\
650 & 1 & 51 & 313 & $35,4 \pm 2$ & $-1,65 \pm 0,02$ \\
650 & 2 & 54 & 345 & $30,2 \pm 2,1$ & $-0,33 \pm 0,01$ \\
\hline 700 & 0,2 & 43 & 156 & $101,83 \pm 4,8$ & $-0,175 \pm 0,02$ \\
700 & 0,5 & 42 & 250 & $91,1 \pm 5,8$ & $-0,55 \pm 0,03$ \\
700 & 1 & 41 & 330 & $75,4 \pm 4$ & $-0,69 \pm 0,02$ \\
700 & 2 & 44 & 390 & $55,9 \pm 2,9$ & $-1,10 \pm 0,07$ \\
\hline 750 & 0,2 & 4 & 172 & $103,7 \pm 4,4$ & $-1,07 \pm 0,04$ \\
750 & 0,5 & 3 & 250 & $101,8 \pm 4,7$ & $-0,59 \pm 0,03$ \\
750 & 1 & 2 & 345 & $64,2 \pm 3,7$ & $-1,61 \pm 0,01$ \\
750 & 1,5 & 6 & 345 & $86,7 \pm 3,9$ & $-2,25 \pm 0,03$ \\
750 & 3 & 7 & 320 & $29,4 \pm 2,8$ & $-1,21 \pm 0,06$ \\
\hline 800 & 0,2 & 24 & 200 & $98,1 \pm 4,8$ & $-1,70 \pm 0,02$ \\
800 & 1 & 21 & 320 & $98,1 \pm 4,7$ & $-0,32 \pm 0,03$ \\
800 & 1,5 & 26 & 345 & $91,1 \pm 6$ & $0,64 \pm 0,01$ \\
800 & 2 & 22 & 345 & $27,8 \pm 2$ & $-1,22 \pm 0,05$ \\
800 & 3 & 23 & 375 & $62,6 \pm 3,8$ & $-1,36 \pm 0,07$ \\
\hline 850 & 0,2 & 31 & 188 & $118,8 \pm 5,4$ & $-0,30 \pm 0,01$ \\
850 & 0,5 & 32 & 190 & $148,8 \pm 6,3$ & $-0,45 \pm 0,07$ \\
850 & 1 & 33 & 220 & $108,3 \pm 4,5$ & $-0,63 \pm 0,03$ \\
850 & 2 & 35 & 330 & $34,42 \pm 2,2$ & $-0,36 \pm 0,01$ \\
850 & 3 & 36 & 376 & $42,3 \pm 2,1$ & $-0,38 \pm 0,02$ \\
\hline
\end{tabular}

*Az egyes értékek előtt a ,„-" előjel a nyomó (compressive) típusú eredő belső feszültséget jelöli. 
12.3. függelék Az illesztéssel meghatározott SiV ZPL spektrális paraméterei, valamint a DebyeWaller (DW) faktor a különbözö leválasztási paraméterek mellett elöállitott nanogyémánt vékonyrétegekben:

\begin{tabular}{ccccccc}
\hline Minta & SiVZPL & SiVZPL hiba & Si $V_{\text {FWHM }}$ & SiVFWHM hiba & DW faktor & DW faktor \\
& $(\mathrm{eV})$ & $(\mathrm{eV})$ & $(\mathrm{eV})$ & $(\mathrm{eV})$ & & hiba \\
\hline 2 & 1,6796 & $2,28831 \mathrm{E}-4$ & 0,00826 & $3,57483 \mathrm{E}-4$ & 0,84805 & 0,01929 \\
3 & 1,6780 & $1,88747 \mathrm{E}-4$ & 0,01639 & $2,25025 \mathrm{E}-4$ & 0,70229 & 0,01826 \\
4 & 1,6787 & $2,91936 \mathrm{E}-4$ & 0,00931 & $3,03165 \mathrm{E}-4$ & 0,69496 & 0,02501 \\
6 & 1,680 & $1,81326 \mathrm{E}-4$ & 0,00648 & $2,19069 \mathrm{E}-4$ & 0,7513 & 0,02214 \\
7 & 1,6799 & $1,15842 \mathrm{E}-4$ & 0,00829 & $4,57211 \mathrm{E}-4$ & 0,7617 & 0,02171 \\
21 & 1,6781 & $2,81518 \mathrm{E}-4$ & 0,01247 & $5,2062 \mathrm{E}-4$ & 0,71761 & 0,01639 \\
22 & 1,6796 & $2,59812 \mathrm{E}-4$ & 0,00672 & $1,94198 \mathrm{E}-4$ & 0,76801 & 0,0337 \\
23 & 1,680 & $1,13543 \mathrm{E}-4$ & 0,01014 & $3,22678 \mathrm{E}-4$ & 0,76258 & 0,01468 \\
24 & 1,6790 & $2,03467 \mathrm{E}-4$ & 0,00912 & $3,91041 \mathrm{E}-4$ & 0,62289 & 0,02297 \\
26 & 1,6778 & $2,39959 \mathrm{E}-4$ & 0,01809 & $3,82721 \mathrm{E}-4$ & 0,66375 & 0,00967 \\
31 & 1,6774 & $2,02034 \mathrm{E}-4$ & 0,01238 & $1,85229 \mathrm{E}-4$ & 0,71931 & 0,00984 \\
32 & 1,6785 & $1,51291 \mathrm{E}-4$ & 0,0139 & $1,22434 \mathrm{E}-4$ & 0,69378 & 0,01596 \\
33 & 1,6796 & $1,42351 \mathrm{E}-4$ & 0,01036 & $2,60311 \mathrm{E}-4$ & 0,75044 & 0,00867 \\
35 & 1,6792 & $1,88963 \mathrm{E}-4$ & 0,01184 & $5,78217 \mathrm{E}-4$ & 0,66426 & 0,01052 \\
36 & 1,6783 & $2,20868 \mathrm{E}-4$ & 0,01124 & $4,70682 \mathrm{E}-4$ & 0,71916 & 0,01843 \\
41 & 1,6781 & $2,52194 \mathrm{E}-4$ & 0,00973 & $4,41269 \mathrm{E}-4$ & 0,75898 & 0,01472 \\
42 & 1,6794 & $2,2761 \mathrm{E}-4$ & 0,01127 & $1,96883 \mathrm{E}-4$ & 0,75044 & 0,01561 \\
43 & 1,6775 & $2,40456 \mathrm{E}-4$ & 0,01418 & $3,29376 \mathrm{E}-4$ & 0,70399 & 0,02293 \\
44 & 1,6802 & $1,96045 \mathrm{E}-4$ & 0,0072 & $4,98321 \mathrm{E}-4$ & 0,77871 & 0,01502 \\
51 & 1,6794 & $2,37055 \mathrm{E}-4$ & 0,01018 & $4,53713 \mathrm{E}-4$ & 0,78293 & 0,02663 \\
52 & 1,6798 & $1,41973 \mathrm{E}-4$ & 0,00926 & $4,97771 \mathrm{E}-4$ & 0,87513 & 0,01236 \\
53 & 1,6780 & $2,43992 \mathrm{E}-4$ & 0,01503 & $3,98099 \mathrm{E}-4$ & 0,74883 & 0,02789 \\
54 & 1,6788 & $2,14984 \mathrm{E}-4$ & 0,01314 & $3,62648 \mathrm{E}-4$ & 0,75109 & 0,01679 \\
\hline & & & & & &
\end{tabular}

